KeILA PACHeCo FerReira

\title{
Responsabilidade Civil Preventiva FunÇÃo, Pressupostos e Aplicabilidade
}

\author{
TESE DE DOUTORADO \\ Orientadora: Professora TitUlar TEReSA ANCONA LoPEZ
}

FACUlDADE DE DiREITo DA UnIVERSIDADE DE SÃo PAUlo

SÃO PAULO

2014 


\title{
KeILA PACHECo FERREIRA
}

\section{Responsabilidade Civil Preventiva}

\section{FunÇão, Pressupostos e APLICABILIDAde}

\author{
TESE DE DOUTORADO APRESENTADA À \\ FACULDADE DE DIREITO DA UNIVERSIDADE DE \\ SÃO PAULO, COMO EXIGÊNCIA PARCIAL PARA A \\ OBTENÇÃO DO TÍTULO DE DOUTORA EM \\ DIREITO. \\ DEPARTAMENTO: DiREITO CIVIL \\ Orientadora: Professora Titular Teresa \\ ANCONA LOPEZ. \\ (VERSÃO CORRIGIDA, NOS TERMOS DA \\ RESOLUÇÃO COPGR No 6018/11. A VERSÃO \\ ORIGINAL ESTÁ DEPOSITADA NA BIBLIOTECA DA \\ FACULDADE DE DIREITO DA USP).
}

FACULDADE DE DiREITO DA UNIVERSIDADE DE SÃo PAULO

SÃO PAULO

2014 
À minha amada filha Lorena, razão de dias felizes.

Aos meus pais, Izoldino e Mariluz, pela força inabalável e apoio irrestrito em todos os momentos.

Ao Solon Júnior, pelo companheirismo, há tantos anos.

À minha irmã Lismara, ao cunhado Páris e aos sobrinhos Laís e Klaus, por compartilharmos uma familia.

À todos que movimentaram vidas, esforços e vibrações positivas para a realização deste projeto. 


\section{AgRAdeCIMENTOS}

Foi uma glória ter me tornado doutoranda na tradicional Faculdade de Direito do Largo São Francisco sob a condução da Professora Titular Teresa Ancona Lopez. Da docente excepcional, recebi as empolgantes lições que me levaram a adotar a Responsabilidade Civil como objeto de pesquisa e de paixão. Da pessoa humana, contei com sensibilidade decisiva para que eu lograsse êxito na conclusão da tese. Não há gestos suficientes para agradecer, senão dar continuidade e estímulo às futuras gerações através dos estudos dessa brilhante professora. Em suma: honra de poucos e benefícios para muitos!

Agradeço aos ilustres membros da banca avaliadora da tese - Professora Patrícia Faga Iglecias Lemos, Professor Marco Fábio Morsello, Professor Rogério Ferraz Donnini, Professor Wanderley Fernandes -, pelas valiosas observações que contribuíram para o aprimoramento deste trabalho. 


\section{RESUMO}

As variantes evolutivas da sociedade, especialmente a pós-moderna, com sua inerente complexidade e riscos, provocam a releitura das funções e estrutura da responsabilidade civil. À referida figura jurídica tanto pela observação ontológica (ser) como deontológica (dever-ser) cumpre tantos modelos quanto forem necessários à revitalização da vítima e avançando além do escopo reparatório - à inerente preservação da pessoa humana considerada em suas dimensões individual e coletiva, em órbita de intangibilidade essencial (segurança), pois há danos de intensidade irreparável. O escopo da presente tese é justamente investigar a fragmentação da responsabilidade civil conforme as vicissitudes contemporâneas, imprimindo, para além do silogismo dedutivo-estruturalista, telos argumentativo-funcional, mediante as operações hermenêuticas possíveis proporcionadas pelos Princípios da Precaução e Prevenção, o que permite anunciar o modelo de Responsabilidade Civil Preventiva.

Palavras-chave: Responsabilidade Civil Preventiva - Funções da Responsabilidade Civil - Princípio da Precaução - Princípio da Prevenção 


\begin{abstract}
The constant evolution of society, especially the postmodern, with its inherent complexity and risk, promotes a new reading of functions and structure of liability. To this legal figure, both by ontological as deontological observation, meets any models as necessary for the revitalization of the victim and - moving beyond the scope of reparation - the inherent preservation of the essential intangibility (safety) of the human beings, considered in their individual and collective dimensions, because there are intense and irreparable damages. The scope of this thesis is precisely to investigate the civil liability fragmentation under the contemporary dynamic social changes, bringing, beyond the reasoning deductivestructuralist, meaning argumentative-functional, through the hermeneutical provided by the Precautionary Principle and Prevention, which allows to announce the Preventive Liability model .
\end{abstract}

Keywords : Functions of Liability - Precautionary Principle - Prevention 


\section{RIASSUNTO}

Le varianti evolutive della società, specialmente di quella post moderna, con la sua inerente complessità e i suoi rischi, portano ad una rilettura delle funzioni e della struttura della responsabilità civile. Alla figura giuridica in questione tanto tramite l'osservazione ontologica (essere) quanto quella deontologica (dover essere) spettano tanti modelli quanti siano necessari alla rivitalizzazione della vittima e - andando al di là del mero fine riparatorio - all'inerente preservazione della persona umana considerata nelle sue dimensioni sia individuale che collettiva, nell'orbita dell'essenziale intangibilità (sicurezza), in quanto danni di irreparabile intensità. Obiettivo della presente tesi è precisamente l'investigazione della frammentazione della responsabilità civile ai sensi delle vicissitudini contemporanee, dandole, al di là del sillogismo deduttivo-strutturalista, una finalità argomentativo-funzionale, mediante le possibili operazioni ermeneutiche fornite dai Principi di Precauzione e Prevenzione, il che pemette di annunciare il modello della Responsabilità Civile Preventiva.

Parole-chiave: Responsabilità Civile Preventiva - Funzioni della Responsabilità Civile Principio di Precauzione - Principio di Prevenzione 


\section{SUMÁRIO}

INTRODUÇÃO.

PARTE I - ABORDAGEM SISTÊMICA E FUNCIONAL DA RESPONSABILIDADE CIVIL

\section{CAPÍTULO 1. A RESPONSABILIDADE CIVIL PREVENTIVA COMO NOVO} MODELO PROPOSITIVO DO DIREITO OBRIGACIONAL

1.1. BREVE APROXIMAÇÃO HISTÓRICO-EVOLUTIVA DA RESPONSABILIDADE CIVIL

1.2. CRISE DA MODERNIDADE REFLEXIVA: A SOCIEDADE GLOBAL DE RISCO

1.3. A RESPONSABILIDADE COMO DEVER DA ÉTICA CONTEMPORÂNEA.

\section{CAPÍTULO 2. ENFOQUE FUNCIONALISTA COMO ESTRATÉGIA PROSPECTIVA} DA RESPONSABILIDADE CIVIL

2.1. CAUSAS SUBJACENTES À TEORIA FUNCIONALISTA DO DIREITO.

2.2. DO ESTRUTURALISMO AO FUNCIONALISMO: GIRO METODOLÓGICO PARA A AMBIENTAÇÃO DA RESPONSABILIDADE CIVIL PREVENTIVA

2.4. A INSUFICIÊNCIA DA FUNÇÃO REPARATÓRIA E O ESTABELECIMENTO DE UMA FUNÇÃO PREVENTIVA PROSPECTIVA DA RESPONSABILIDADE CIVIL

PARTE II - A ARQUITETURA DA RESPONSABILIDADE CIVIL PREVENTIVA.

\section{CAPÍTULO 1. PRINCIIPIOS JURÍDICOS ESTRUTURANTES DA} RESPONSABILIDADE CIVIL PREVENTIVA.

1.1. PRINCÍPIOS DA PRECAUÇÃo E dA PREVENÇÃo E A METOdOLOGIA DE INTERPRETAÇÃo dA RESPONSABILIDADE CIVIL PREVENTIVA: A HERMENÊUTICA DA SUSPEIÇÃO.

1.2. GÊNESE DO PRINCÍPIO DA PRECAUÇÃO E ÂMBITO DE APLICAÇÃO. 
1.3. A NORMATIVIDADE DO PRINCÍPIO DA PRECAUÇÃO E SUA INTEGRAÇÃO À RESPONSABILIDADE CIVIL: UMA RELAÇÃO DIALÓGICA E DINÂMICA.

1.4. RISCO E INCERTEZA: CONDIÇÕES PARA A APLICAÇÃO DO PRINCÍPIO DA PRECAUÇÃO. 101

1.5. CONCEITO DE RISCO E TIPOLOGIA CONFORME A GRADUAÇÃO DE INCERTEZA: DO PRINCÍPIO DA PREVENÇÃO AO PRINCÍPIO DA PRECAUÇÃO

1.6. INCERTEZA CIENTÍFICA E GERENCIAMENTO PROPORCIONAL DE RISCOS: AVALIAÇ̃̃O (RISK ASSESSMENT), GESTÃO (RISK MANAGEMENT) E INFORMAÇÃO (RISK COMMUNICATION).

CAPÍTULO 2. DEVERES E BENS JUSTIFICADORES DA RESPONSABILIDADE CIVIL PREVENTIVA: O PARADIGMA DA FUNDAMENTALIDADE

CAPÍTULO 3. INCIDÊNCIA DA FUNÇÃO PREVENTIVA PROSPECTIVA ATRAVÉS DOS CAMPOS NORMATIVOS DOS ILÍCITOS CIVIS.

3.1. A PRECAUÇÃO E A PREVENÇÃO COMO PARÂMETROS PARA A AVALIAÇÃO DA CONDUTA EXIGÍVEL

3.2. O ABUSO DO DIREITO DEMARCARDO PELOS DEVERES DE PRECAUÇÃO E DE PREVENÇ̃̃O

3.3. DISTINÇÃO ENTRE ILÍCITO E DANO PARA APLICAÇÃO DAS TUTELAS DE CONTROLE DO RISCO: A RESPONSABILIDADE CIVIL COMO SISTEMA

3.4. CLÁUSULA GERAL DE RESPONSABILIDADE CIVIL PREVENTIVA NA TUTELA DAS SITUAÇÕES JURÍDICAS SUBJETIVAS EXISTENCIAIS

\section{CAPÍTULO 4. DANO E INDENIZAÇÃO SOB PARADIGMAS FUNCIONAIS: DO} RETROSPECTO INDENIZATÓRIO À PROSPECÇÃO DE DANOS

4.1. DANO COMO LESÃO A UM INTERESSE JURÍDICO TUTELÁVEL

4.2. ANTECIPAÇÃO DA REALIZAÇÃO DO DANO: ENTRE ANTIGOS DOGMAS E O DINAMISMO DA JURISPRUDÊNCIA 
4.3. A INFORMAÇÃO COMO MECANISMO DE PREVENÇ̃̃O DO DANO

4.3.1. SEGURANÇA ALIMENTAR E UM CASO PARADIGMÁTICO: DOENÇA CELÍACA E DEFEITO DE INFORMAÇÃO NA JURISPRUDÊNCIA DO STJ.

4.3.2. DEVER DE INFORMAR E CONTROVÉRSIAS ACERCA DA ROTULAGEM DE OGM

CAPÍTULO 5. NEXO DE CAUSALIDADE: ENTRE RISCO, (IN)CERTEZA E PROBABILIDADE

5.1. DA CAUSALIDADE MATERIAL À CAUSALIDADE JURÍDICA: RESPONSABILIDADE PRESUMIDA

5.1.1. COMPROVAÇÃO DE RISCOS E A MITIGAÇÃO DA CARGA PROBATÓRIA NA JURISPRUDÊNCIA.

5.1.2. TEORIA DA CAUSALIDADE POR COTA NO MERCADO (MARKET SHARE LIABILITY) E O CASO DO ESTROGÊNIO SINTÉTICO.

5.2. RISCOS DO DESENVOLVIMENTO COMO EXCLUDENTE DE RESPONSABILIDADE: UMA OPÇÃO DE POLÍTICA LEGISLATIVA.

CONCLUSÃO: UMA PROPOSTA DE MODELO OPERATIVO PARA A RESPONSABILIDADE CIVIL PREVENTIVA 


\section{INTRODUÇÃO}

A tese ora apresentada versa sobre o que se considera a mais recente fase de evolução da responsabilidade civil, ${ }^{1}$ em que esse instituto passa a assumir, diante da complexidade e riscos da sociedade contemporânea, também uma função preventiva prospectiva, o que por sua vez, provoca sensíveis modificações na maneira como os seus fundamentos e pressupostos são interpretados.

Se o paradigma que dominou a dogmática da responsabilidade civil no século XX foi aquele de opor análise do mau uso da liberdade pelo agente (culpa), frente à atividade lucrativa geradora de dano (risco), portanto, preso à conduta e à estrutura metodológica de então, em tempos presentes exsurge nova perspectiva: a fragmentação do instituto, que assume como escopo o cumprimento de múltiplas finalidades. O que agora se opõe, é o modelo reparatório frente a modelos polivalentes.

Daí articular a responsabilidade civil não mais como sinônimo de indenização ou perdas e danos, senão como sistema, processo e instituição. ${ }^{2} \mathrm{Na}$ perspectiva de sistema, vai além da dicotomia outrora sustentada quanto à natureza (contratual ou extracontratual), esboçando que o campo de abrangência deve ser adequado à sociedade pós-moderna, o que permite flexibilizar e reformular seus elementos constitutivos a partir do caso concreto. Como processo (ou movimento orgânico), é investigada na temporalidade, importando em situações jurídicas não apenas de execução, mas igualmente de pré-responsabilidade (prevenção) e pós-responsabilidade (repercussão do dano e equidade intergeracional). Por fim, como instituição, esboça reação própria lhe deferida pelo sistema jurídico e, nesse contexto, refere-se à ampla exigência de efetividade: proteção pro damnato.

O título proposto - Responsabilidade Civil Preventiva - retrata a temática

1. LOPEZ, Teresa Ancona. Princípio da precaução e evolução da responsabilidade civil. São Paulo: Quartier Latin, 2010, p.55, afirma que "a responsabilidade civil no século XXI vai sair robustecida com a recepção em seu sistema dos princípios da precaução e da prevenção e da reparação integral das vítimas por meio de fundos de garantia e seguros obrigatórios no caso de o acidente acontecer".

2. LORENZETTI, Ricardo Luis. Teoría general del contrato y de los servicios: una teoría sistémica del contrato. Contratos de servicios a los consumidores. Santa Fe: Rubinzal-Culzoni, 2005, p.18. 
central da pesquisa realizada, qual seja, a ultrapassagem de uma função estritamente reparatória de danos, para um estágio em que os mecanismos do instituto são utilizados também como instrumentos para o gerenciamento de riscos e prevenção de danos. Para tanto, parte-se da premissa, embasada por fundamentos sociológicos, axiológicos e jurídicos, de que os princípios da precaução e da prevenção estruturam um novo modelo de responsabilidade civil. Para delimitar o âmbito da investigação realizada, no intuito de esclarecer as balizas da análise explorada, utilizou-se a especificação no subtítulo, qual seja - função, pressupostos e aplicabilidade.

Ao tratar da função, a tese tem por objetivo averiguar se a responsabilidade civil hodierna, impulsionada por influxos de ordem social e filosófica, abarcou novas atribuições, que a direciona a produzir um efeito emancipatório. Ao indagar quais são os valores e resultados que o ambiente social confere expectativa para atuação de suas normas, depara-se com a constatação de que esse instituto, na contemporaneidade, atravessa um momento em que ao rol de funções tradicionais adiciona-se a preventiva, orientada para o futuro.

Por sua vez, após verificação de que a responsabilidade civil internalizou também uma função preventiva prospectiva, em decorrência, parte-se para a investigação acerca da arquitetura assumida por esse modelo, em que os pressupostos apresentam nova roupagem e exigem hermenêutica diferenciada. A seu turno, juntamente com a assunção de que há uma configuração renovada, é relevante demonstrar a aplicabilidade desta proposta. Com efeito, a projeção casuística da análise jurídica realizada permitirá ao intérprete uma melhor compreensão de sua operabilidade e setores de aplicação. ${ }^{3}$

Do estudo empreendido, adianta-se, em linhas gerais, que profundas transformações perpassam a responsabilidade civil. E tal não poderia ser diferente, neste século XXI, no qual a exposição diuturna a uma multiplicidade de riscos é inerente à sociedade pós-moderna, constituindo o lado sombrio do desenvolvimento tecnocientífico e do almejado progresso social. Nesse contexto, o Direito, como construção cultural que é,

3. GODOY, Cláudio Luiz Bueno de. Responsabilidade civil pelo risco da atividade. São Paulo: Saraiva, 2009, p.110, ao considerar que o direito encerra uma ciência eminentemente prática, voltada à disciplina de situações concretas da vida de relações, externa a preocupação de se demonstrar a operatividade dos conceitos teóricos, bem como exemplificação da concreta incidência reservada ao conteúdo proposto. 
não poderia deixar de refletir tão significantes mutações.

Desponta, assim, com renovados fundamentos, funções, pressupostos e âmbito de aplicação, a Responsabilidade Civil Preventiva. A investigação dessa nova perspectiva é o escopo que anima a presente tese, tomando-se de empréstimo as palavras certeiras de Iturraspe e Piedecasas:

La doctrina más reciente ha caído en la cuenta de la enorme trascendencia de la prevención o evitación del perjuicio, de las acciones positivas orientadas a que el daño no se produzca, afectando a personas o a bienes, o bien, si ya se ha causado, a disminuir sus efectos o hacerlos cesar. El adagio popular: "prevenir es mejor que curar" ha recibido la aceptación del Derecho. ${ }^{4}$

A pesquisa realizada é capaz de trazer contributo original à ciência jurídica brasileira, por demonstrar a maneira pela qual a função preventiva prospectiva assumida pela responsabilidade civil vai alterar a configuração dos pressupostos para a atribuição de responsabilidade. Ademais, ao enfrentar a tarefa de expor uma racionalidade diversa e inovadora da responsabilidade civil (um novo modelo), colabora-se para a construção de um sistema jurídico dialógico, o que permitirá a coexistência e a articulação interna de regras destinadas à reparação (Responsabilidade Civil Reparatória), outras dirigidas à prevenção (Responsabilidade Civil Preventiva), além daquelas dedicadas à garantia da indenização (Socialização de Danos).

Cabe ressaltar que a temática é recente, complexa, e ainda pouco difundida pragmaticamente, seja a nível nacional ou estrangeiro. Sendo assim, não é o propósito desta tese exaurir ou atribuir um contorno definitivo ao seu conteúdo, mas sim evidenciar as pistas, mostrar os campos normativos possiveis através dos quais a Responsabilidade Civil Preventiva já caminha rumo a uma ampla e segura consolidação. Neste sentido, relembramos a advertência de Menezes Cordeiro:

Mais importante do que apontar - ou querer apontar - uma solução definitiva, numa pretensão que logo, só por si, se revelaria acientífica, é descobrir o sentido de uma evolução, os seus factores e a sua concatenação, passada, presente e, na medida do

4. ITURRASPE, Jorge Mosset; PIEDECASAS, Miguel A. Responsabilidad por daños: actualización doctrinaria y jurisprudencial de los tomos I a X. Tomo XI. Santa Fe: Runbinzal-Culzoni, 2009, p.21. 
razoável, futura. ${ }^{5}$

Quanto ao método de trabalho, a pesquisa encontra subsídios na doutrina nacional e estrangeira, especialmente (mas não de forma exclusiva) a francesa, país onde a temática trabalhada já alcança maior desenvolvimento, sem perder de vista as peculiaridades do direito positivo nacional e a possibilidade da Responsabilidade Civil Preventiva ser aplicada também no ordenamento brasileiro. Além disso, será demonstrada por meio da averiguação jurisprudencial, de que forma esse novo modelo está sendo absorvido pelos tribunais.

No que tange à abordagem metodológica, a pesquisa seguirá uma concepção crítica em torno do fenômeno jurídico, admitindo que o Direito interfira de forma transformadora na realidade social. O exercício de um pensamento jurídico crítico como diretriz reflexiva é definido como:

[...] um processo de intervenção sobre o saber acumulado, que proporciona a informação necessária para desenvolver um conhecimento analítico capaz de superar as barreiras do nível alcançado pelas ciências sociais [...] O discurso crítico não pode ser nenhuma pretensão de completude, nem pode pretender falar alternativamente em nome de nenhuma unidade ou harmonia, já que está em processo permanente de elaboração [...] realiza análises fragmentadas e transformáveis, próprias de um processo de produção de um novo conhecimento científico. ${ }^{6}$

A investigação tem caráter essencialmente dogmático, conjugada em suas três dimensões: analítica, empírica e normativa. Em consideração à concepção analítica, ocupa-se da análise dos conceitos e a relação entre estes e o direito positivo. A análise do Direito na visão de quem o aplica é tarefa da dimensão empírica da dogmática jurídica. E a dimensão normativa pretende solucionar o problema apresentado. ${ }^{7}$ Portanto, a presente tese, ao cuidar dessas três dimensões, não se esgota apenas na análise teórica, pois também

5. Tratado de Direito Civil Português. Tomo I. Coimbra: Almedina, 2007, p.165.

6. WARAT, Luís Alberto. O sentido comum teórico dos juristas. In: FARIA, José Eduardo (Org.). A crise do Direito numa sociedade em mudança. Brasília: Ed. Universidade de Brasília, 1988, p.35.

7. ALEXY, Robert. Teoria de los derechos fundamentales. Trad. Carlos Bernal Pulido. Madrid: Centro de Estudios Políticos y Constitucionales, 2007, p. 34. Acresce o autor que "La vinculación de las tres dimensiones, tomando en cuenta la orientación hacia la tarea práctica de la ciencia del derecho, constituye lo dogmático $\mathrm{y}$, con ello, lo jurídico en sentido estricto. Si, sobre esta base, se define el concepto de la teoría jurídica, entonces una teoría jurídica de los derechos fundamentales de la Ley Fundamental es una teoría inserta en el contexto de las tres dimenciones y orientada a la tarea práctiva de la ciencia del derecho". 
persegue o escopo de fornecer elementos para a utilização pragmática pelos operadores do Direito.

A premissa metodológica que subjaz a pesquisa, parte da compreensão de que o Direito é um fenômeno dinâmico, incompleto, multifário, e consequentemente, aberto, que requer uma operação jurídico-interpretativa teleológica, capaz de concretizar os valores presentes nas convicções e ideais da sociedade contemporânea. ${ }^{8}$ Nesse paradigma de racionalidade, a abordagem sistêmica da responsabilidade civil confere-lhe capacidade de evolução e modificabilidade, por ser histórica e axiologicamente determinável. ${ }^{9}$ Esse modelo, consoante ressalta Francisco Amaral:

[...] não se apresenta como uma estrutura lógico-dedutiva, mas como uma rede, um entrelaçamento de relações sob o predomínio ou a orientação de princípios jurídicos que funcionam como pautas abertas de comportamento, à espera da necessária concretização. $\mathrm{O}$ movimento interno do sistema não é ascendente, mas circular. ${ }^{10}$

A abordagem do tema mantém sintonia, ainda, com o método do diálogo das fontes, em prestígio a uma hermenêutica de coordenação entre origens normativas diversas e múltiplas, exigível para um sistema jurídico funcional e justo. ${ }^{11}$

É nesse ambiente e através do mencionado tratamento metodológico, que o modelo de Responsabilidade Civil Preventiva poderá encontrar o seu pleno desenvolvimento, consoante será verificado no decorrer do texto.

O tema abordado, conforme já foi dito, é enfocado sob três aspectos função, pressupostos e aplicabilidade - o que inspirou a divisão estrutural da tese em duas partes.

8. CANARIS, Claus-Wilhelm. Pensamento sistemático e conceito de sistema na ciência do direito. Int. e trad. A. Menezes Cordeiro. $3^{\mathrm{a}}$ ed. Lisboa: Fundação Calouste Gulbenkian, 2002, p.23.

9. ENGISCH, Karl. Introdução ao pensamento jurídico. Trad. J. Baptista Machado. Lisboa: Fundação Calouste Gulbenkian, 2001, p.236.

10. AMARAL, Francisco. Racionalidade e sistema no direito civil brasileiro. Revista de Direito Civil, $\mathrm{n}$. 63, p. 45-56, jan. /mar. 1993.

11. MARQUES, Cláudia Lima; BENJAMIN, Antônio Herman V.; BESSA, Leonardo Roscoe. Manual de direito do consumidor. São Paulo: Editora Revista dos Tribunais, 2007, p.87. Esclarecem: “'Diálogo' porque há influências recíprocas, 'diálogo' porque há aplicação conjunta da duas normas ao mesmo tempo e ao mesmo caso, seja complementarmente, seja subsidiariamente, seja permitindo a opção pela fonte prevalente ou mesmo permitindo uma opção por uma das leis em conflito abstrato - uma solução flexível e aberta, de interpenetração, ou mesmo a solução mais favorável ao mais fraco da relação (tratamento diferente dos diferentes)." 
Os capítulos componentes da Parte I abordam a responsabilidade civil de forma sistêmica e funcional, reconhecendo na mesma um novo modelo propositivo do direito obrigacional. Em sequência, na Parte II, uma vez confirmada a asserção de que foi ampliado o espectro de atuação do instituto para adequá-lo aos contornos típicos da sociedade pós-moderna e de riscos, em um segundo momento, é empreendida investigação acerca dos fundamentos e alterações que esta nova compreensão de responsabilidade provoca em seus pressupostos. Esta análise conjuga-se com a aplicabilidade, ou seja, a verificação concreta da possibilidade pragmática de sua atuação.

É de Santo Agostinho a rica passagem sobre o tempo:

Nem o futuro nem o presente existem; isso agora está muito claro. Nem se pode dizer propriamente que os tempos são três: passado, presente e futuro. Talvez fosse melhor dizer que os tempos são: o presente do passado; o presente do presente; o presente do futuro. $\mathrm{E}$ estes estão na alma; não os vejo alhures. O presente do passado é a memória, o presente do presente é a percepção, o presente do futuro é a expectativa. ${ }^{12}$

São justamente os sinais, os riscos, as ameaças, as incertezas que fazem a responsabilidade civil tornar-se instituto jurídico notável também para a prevenção de danos, postando-se como consentânea aos direitos, aos bens e deveres fundamentais de ampla tutela. É disso que esta tese trata.

Feita a introdução, passamos a seguir, a tratar da Responsabilidade Civil Preventiva em concreto.

12. NICOLA, Ubaldo. Antologia ilustrada de filosofia: das origens à idade moderna. Trad. Maria Margherita De Lucca. São Paulo: Globo, 2005, p.132. 
- PARTE I -

\title{
ABORDAGEM SISTEMMICA E FUNCIONAL DA RESPONSABILIDADE CIVIL
}

\section{CAPÍTULO 1. A RESPONSABILIDADE CIVIL PREVENTIVA COMO NOVO MODELO PROPOSITIVO DO DIREITO OBRIGACIONAL}

\begin{abstract}
Nós, exploradores do futuro, nos parecemos com os antigos cartógrafos, e é com esse espírito que o conceito de "Choque do Futuro" e a teoria do alcance de adaptação são aqui apresentados não como uma palavra final, mas como uma aproximação preliminar a novas realidades, impregnada de perigos e promessas, produzidas pelo impulso acelerador que nos atira para os domínios do amanhã. ${ }^{13}$ (Alvin Toffler)
\end{abstract}

A citação em epígrafe, escrita há mais de quarenta anos pelo professor, escritor e futurólogo norte-americano Alvin Toffler, apresenta-nos um alerta sobre o ponto de tensão entre o pretérito e o porvir, o conservador e contemporâneo, o legado e a renovação. Através da provocativa designação "Choque do Futuro", enuncia-se o declínio da permanência e a passagem de um mundo estável para um ambiente de transformações em contínua aceleração, do qual emerge uma irrefragável transitoriedade em diversos setores sociais e humanos, alterando sistemas gerenciais, economia, tecnologia, ciência e identidades.

De acordo com o referido autor, ${ }^{14}$ a desorientação e sensação de efemeridade induzida por excessivas transformações em um intervalo temporal demasiadamente curto estariam presentes em diversos domínios. Nos aspectos existencial e relacional, seria verificado: a) na ênfase da transitoriedade em relação às coisas, lugares, pensamentos, estruturas organizacionais e relações interpessoais; b) na fragmentação $e$ diversidade de arranjos familiares; c) na variedade de estilos de vida e diversificação de valores, fabricados pelos meios de comunicação e alta volatilidade das informações; d) no

13. TOFFLER, Alvin. O choque do futuro. Trad. Marco Aurélio de Moura Matos. Rio de Janeiro: Artenova, 1973, p.14.

14. TOFFLER, Alvin. Op. cit., p. 34 et seq. 
desgaste emocional, psicológico, social e físico do ser humano, em decorrência da sobrecarga de informações e limites de adaptação própria do biossistema humano; e) na necessidade de a educação superar currículos obsoletos que impõem padronizações $e$ homogeneidade.

Já nos campos social, econômico, científico e tecnológico, as perspectivas sobre o "Choque do Futuro" sugerem: a) a imposição de uma nova cultura; b) a extirpação do pensamento econômico ortodoxo; c) uma transformadora trajetória científica e inerente habilidade em modificar profundamente o estado das coisas, projetando o homem para o imprevisível; d) a premência de uma tecnologia domada, através da qual se destaca como estratégia a regulamentação consciente, ao diagnosticar-se que a par do desejável aumento do poderio tecnológico, os seus efeitos colaterais e potenciais sofrem incremento vertiginoso. Diante disso, surge a constatação de que:

[...] não é de modo algum suficiente o ato de investigar e vincular responsabilidades depois da ocorrência do fato [...] Isso quer significar o surgimento da maquinaria do governo assim como o da maquinaria privada, para revisar os progressos tecnológicos de maior vulto antes de serem lançados ao consumo ou à utilização do público [...] A política do controle da tecnologia provocará conflitos violentos nos dias que estão por vir. Mas com conflito ou sem conflito, a tecnologia precisa ser domada, para que o processo acelerativo possa ser controlado. E o impulso acelerativo deve ser controlado, se quisermos evitar o choque do futuro. ${ }^{15}$

Quatro décadas mais tarde, o "Choque do Futuro" idealizado na obra acima referida, tornou-se vida pulsante e realidade corrente. Através da experiência comum, é possível constatar que na consolidação da passagem da modernidade para a contemporaneidade, inúmeras previsões tornaram-se fato, o que contribuiu para o surgimento de singulares tipos de sistema sociais. ${ }^{16}$

15. TOFFLER, Alvin. Op.cit., p.369-371.

16. Destaca-se que não há uma distinção cronológica ou qualitativa tão precisa entre os diversos "tipos de sistemas sociais", e a expressão aqui foi empregada no sentido exposto por BAUMAN, Zygmunt. Vida para consumo: a transformação das pessoas em mercadorias. Trad. Carlos Alberto Medeiros. Rio de Janeiro: Jorge Zahar Ed., 2008, p.39, por sua vez amparado em Max WEBER: "Como sugeriu Weber, os "tipos ideais" (se construídos de maneira adequada) são ferramentas cognotivas úteis, e também indispensáveis, ainda que (ou talvez porque) iluminem deliberadamente certos aspectos da realidade social descrita enquanto deixam na sombra outros aspectos considerados de menos ou escassa relevância para os traços essenciais e necessários de uma forma de vida particular. "Tipos ideais" não são descrições da realidade, mas ferramentas usadas para analisá-la.”. 
Assim, ao empreender-se um exame sociológico dos tempos atuais, é possível identificar diversos segmentos: a sociedade de riscos, caracterizada pelo sociólogo alemão Ulrich Beck, ${ }^{17}$ âmbito o qual ocorre o despertar de consciência sobre as ameaças produzidas pela própria sociedade que, diante do imprevisível, vê-se impossibilitada de controlar os perigos gerados como resultado da modernização; a sociedade de consumo, retratada por cientistas sociais e filósofos como Jean Baudrillard, ${ }^{18}$ Zygmunt Bauman ${ }^{19}$ e Gilles Lipovetsky; ${ }^{20}$ a sociedade de informação, cuja diagnose pode ser compreendida através do pensamento de Manuel Castells, ${ }^{21}$ e ainda, a sua derivada sociedade de vigilância, cujos reflexos sobre o direito à privacidade ${ }^{22}$ são alvo de preocupações expostas por Stefano Rodotà. ${ }^{23}$

17. Em decorrência da especial influência que o pensamento de Ulrich BECK exerce sobre o tema da tese ora trabalhada, a sociedade de riscos será abordada de forma mais pormenorizada no subcapítulo 1.2 , infra.

18. O sociólogo francês BAUDRILLARD, Jean. A sociedade de consumo. Lisboa: Edições 70, 2007, enfatiza o significado dos objetos e a importância do seu consumo no relacionamento entre as pessoas e consequente satisfação e realização, além de identificar a obsolescência como forte característica dessa sociedade, incentivada por técnicas de publicidade.

19. Por sua vez, sobre o consumismo pós-moderno, destaca o cientista social polonês BAUMAN, Zygmunt. Vida para consumo: a transformação das pessoas em mercadorias. Trad. Carlos Alberto Medeiros. Rio de Janeiro: Jorge Zahar Ed., 2008, p.63: "A sociedade de consumo tem como base de suas alegações a promessa de satisfazer os desejos humanos em um grau que nenhuma sociedade do passado pôde alcançar".

20. A seu turno, o filósofo e professor francês LIPOVETSKY, Gilles. A felicidade paradoxal: ensaio sobre a sociedade de hiperconsumo. Trad. Maria Lúcia Machado. São Paulo: Companhia das Letras, 2007, desvenda que nos tempos atuais, experimenta-se o terceiro estágio do capitalismo - a "sociedade do hiperconsumo", geradora de um tipo de consumidor pelo autor alcunhado "homo consumericus", cujo consumo, ainda voraz, associa-se à experiências emocionais de bem-estar, marcas, autenticidade e segmentação.

21. O sociólogo espanhol Manuel CASTELLS dedica-se aos estudos sobre os reflexos da tecnologia e da informação para a reestruturação organizacional da sociedade na trilogia "A Era da Informação: economia, sociedade e cultura". Na obra CASTELLS, Manuel. A sociedade em rede. Vol. 1. $2^{\mathrm{a}}$ ed. Trad. Roneide Venancio Majer e Klauss Brandini Gerhardt. São Paulo: Paz e Terra, 1999, p.21 e 23, o autor identifica: "Uma revolução tecnológica concentrada nas tecnologias da informação está remodelando a base material da sociedade em ritmo acelerado. Economias por todo o mundo passaram a manter interdependência global, apresentando uma nova forma de relação entre a economia, o Estado e a sociedade em um sistema de geometria variável [...]".

22. "The right to privacy", dos autores Samuel D. WARREN e Louis BRANDEIS, publicado na Harvard Law Review em dezembro de $1890 . \quad$ Disponível em: $<$ http://groups.csail.mit.edu/mac/classes/6.805/articles/privacy/Privacy_brand_warr2.html>. Acesso em: 20 jul. 2013. Acesso em: 20 jul. 2013.

23. O jurista italiano apresenta três questões essenciais pertinentes ao desenvolvimento das ferramentas da tecnologia da informação (sobretudo internet) que permitem o conhecimento de dados pessoais, e sua correlação com o direito à privacidade: "talvez a privacidade esteja morrendo; então, quais são os valores fundantes da presença das pessoas no mundo? E qual é a incidência disso tudo sobre os sistemas políticos?" (RODOTÀ, Stefano. A vida na sociedade de vigilância: a privacidade hoje. Trad. 
Evidentemente, todas essas profundas e aceleradas transformações no campo social demandaram o descortino de horizontes diversos, o que repercute no alargamento de campos cognoscíveis e na necessidade de um refinamento epistemológico, cujos reflexos são fortemente sentidos também nos domínios do Direito.

Entretanto, é possível perceber que o manancial jurídico utilizado no ultrapassado paradigma da modernidade, especialmente no tocante à responsabilidade civil, não está apto a regular a evolução histórica e os tipos sociais observados no terceiro milênio.

Assim, as contingências e riscos nunca antes visitados acabam por compelir à busca por novas soluções, eclodindo o que Boaventura de Sousa Santos denomina "crise da consciência especular", ${ }^{24}$ quando os espelhos sociais - como o direito, a educação, a informação, a religião e a tradição -, deixam de refletir a realidade vivida, período que, analisado sob uma perspectiva crítica, indica a inevitabilidade de uma transição paradigmática e gestão reconstrutiva da hermenêutica jurídica.

Com efeito, é necessário repensar os instrumentos do Direito ${ }^{25}$ para a efetividade do controle de riscos, o que implica na remodelação de um conjunto de construções jurídico-normativas tradicionais que vigoraram por mais de um século de positivismo jurídico, e na admissão da fragmentação da responsabilidade civil para a ressignificação dessa instituição que, diante dos desafios propostos na atualidade, acaba desacreditada em seus fundamentos e objetivos. Para tanto, a assunção de uma função preventiva prospectiva pela responsabilidade civil é capaz de ensaiar um passo além do estabelecido, e construir um novo modelo, ao questionar a unicidade retrospectiva vigente,

Danilo Doneda e Luciana Cabral Doneda. Organização, seleção e apresentação Maria Celina Bodin de Moraes. Rio de Janeiro: Renovar, 2008, p.142-143).

24. SANTOS, Boaventura de Sousa. Para um novo senso comum: a ciência, o direito e a política na transição paradigmática. Vol. 1. A crítica da razão indolente: contra o desperdício da experiência. 4. ed. São Paulo: Cortez, 2002, p.48: “[...] em vez de a sociedade se ver reflectida no espelho, é o espelho a pretender que a sociedade o reflicta. De objecto do olhar, passa a ser, ele próprio, olhar. Um olhar imperial e imperscrutável, porque se, por um lado, a sociedade deixa de se reconhecer nele, por outro não entende sequer o que o espelho pretende reconhecer nela [...] A actualidade do olhar deixa de corresponder à actualidade da imagem".

25. Neste sentido, NOIVILLE, Christine. Du bon gouvernement des risques: le droit et la question du "risque acceptable". Paris: Presses Universitaires de France, 2003, p.217. No original: "Savoir ainsi ne pas retenir de la responsabilité un concept univoque constitue probablement la seule manière de redonner du sens à cette institution, aujourd'hui décriée dans ses fondements et dans ses finalités". 
sobretudo ao considerar-se que "todas as crises iniciam com o obscurecimento de um paradigma e o consequente relaxamento das regras que orientam a pesquisa normal". ${ }^{26}$

Quando se observa, na sociedade, que a transformação dos modelos tecnocientífico e de produção trouxeram o incremento do risco como uma realidade, constata-se sem maiores dificuldades certa inadequação da responsabilidade civil reparatória $^{27}$ para cuidar da vida social contemporânea e seus desdobramentos complexidade, contingência, reflexividade. Contudo, recorda Eros Roberto Grau, ${ }^{28}$ que o Direito não atua apenas mediante leis, pois antes destas, convivendo e inteirando com as mesmas, existem valores e princípios, os primeiros, finalísticos, orientando teleologicamente, os segundos, deontológicos. Nesse horizonte, a absorção dos princípios da precaução e da prevenção nos domínios da responsabilidade civil é capaz de romper tradições, reorientar a função, revisitar os pressupostos e variar a aplicabilidade desse fundamental instituto na contemporaneidade.

$\mathrm{Na}$ sociedade atual, é necessário, pois, enfrentar os desafios da complexidade com visão poliocular, conforme adverte Edgar Morin, ${ }^{29}$ através de

26. KUHN, Thomas S. A estrutura das revoluções científicas. $5^{\mathrm{a}}$ ed. São Paulo: Perspectiva, 2000, p.115. E prossegue o filósofo, p.116: "A transição de um paradigma em crise para um novo, do qual pode surgir uma nova tradição de ciência normal, está longe de ser um processo cumulativo obtido através de uma articulação do velho paradigma. É antes uma reconstrução da área de estudos a partir de novos princípios, reconstrução que altera algumas das generalizações teóricas mais elementares do paradigma, bem como muitos de seus métodos e aplicações."

27. BOUTONNET, Mathilde. Le principe de précaution en droit de la responsabilité civile. Paris: L.G.D.J., 2005, p.18 : “o crescimento de catástrofes sanitárias e ecológicas, e as perspectivas para o campo da bioética, demonstram os limites da função reparatória. Há riscos e perigos que ameaçam o futuro da humanidade. (...) Não é necessário intervir antes que a reparação para impedir a realização de danos?" (tradução livre). Em língua original: "la croissance des catastrophes sanitaires et écologiques, et les perspectives concernant le domaine bioéthique, rappellent subitement les limites de la fonction réparatrice. Il existe 'des risques et des dangers qui menacent l'avenir de l'humanité'. Provenant en partie des activités humanines, difficilement réparables et touchant à des intérêts collectifs, précieus, certains dommages provoquent un sursaut de conscience: fault-il vraiment attendre qu'ils se réalisent pour réagir? $\mathrm{Ne}$ devient-il pas nécessaire d'intervenir en amont de la réparation pour éviter la réalisation de ces dommages?"

28. O direito posto e o direito pressuposto. São Paulo: Malheiros, 2005, p.384.

29. Ciência com consciência. Trad. Maria D. Alexandre e Maria Alice Sampaio Dória. 8. ed. Rio de Janeiro: Bertrand Brasil, 2005, p.30: "De toda parte surge a necessidade de um princípio de explicação mais rico do que o princípio de simplificação (separação/ redução), que podemos denominar princípio de complexidade. [...] Esforça-se não por sacrificar o todo à parte, a parte ao todo, mas por conceber a difícil problemática da organização, em que, como dizia Pascal, 'é impossível conhecer as partes sem conhecer o todo, como é impossível conhecer o todo sem conhecer particularmente as partes'. Ele se esforça por abrir e desenvolver amplamente o diálogo entre ordem, desordem e organização, para conceber, na sua especificidade, em cada um dos seus níveis, os fenômenos físicos, biológicos e humanos. Esforça-se por obter a visão poliocular ou poliscópica, em que, por exemplo, as dimensões 
mecanismos redutores, entre os quais o sistema jurídico atua com primazia. A configuração da responsabilidade civil, portanto, deve ser trabalhada no campo da transdisciplinaridade, justamente pelo fato de que deve ser compreendida como uma necessidade social, justificada em seu aspecto filosófico, para depois alcançar a dogmática jurídica.

Nesse passo, reside a proposta do presente capítulo, ao perspectivar a Responsabilidade Civil Preventiva como um novo modelo ${ }^{30}$ propositivo do direito obrigacional, conforme sentido empregado por Miguel Reale:

Essa mudança na compreensão do Direito - do ponto de vista retrospectivo das fontes para o prospectivo dos modelos - importa ou pressupõe, como se vê, uma atitude mais operacional perante as realidades sociais. Não que eu esteja convencido da possibilidade de uma jurisprudência não conceitual, mas sim da necessidade de não ver nos conceitos jurídicos simples esquemas abstratos, isto é, abstraídos do real e separados dele, como tais suscetíveis de serem elaborados em si e por si, sem a sua contínua referência aos fatos, à experiência, onde emergem fatos e valores novos que lhes alteram substancialmente o significado. As tentativas de axiomatização do Direito não têm levado na devida conta a dinamicidade dos modelos jurídicos, irredutíveis a modelos matemáticos ou físicos, dada a sua essencial correlação, não só com fatos e valores novos emergentes, mas também com as mutações oferecidas no macro modelo do ordenamento jurídico global. ${ }^{31}$

De plano, quadra advertir que a paulatina transição para este inovador modus operandi da responsabilidade civil não implica na substituição de sua lógica tradicional, que continuará atuante, entretanto, em seu campo específico de aplicação. ${ }^{32}$

Consoante será demonstrado nos capítulos que seguem, a análise da

físicas, biológicas, espirituais, culturais, sociológicas, históricas daquilo que é humano deixem de ser incomunicáveis".

30. REALE, Miguel. Fontes e modelos do direito: para um novo paradigma hermenêutico. São Paulo: Saraiva, 1994, p.40-41: “[...] modelos jurídicos não são meras criações da mente, mas sim o resultado da ordenação racional do conteúdo das normas reveladas ou formalizadas pelas fontes do direito, para atender aos característicos de validade objetiva autônoma e de atualização prospectiva dessas mesmas normas. A "modelagem" da experiência jurídica é feita, portanto, pelo jurista em contato direto com as relações sociais."

31. REALE, Miguel. Direito e planificação. In: CLÈVE, Clèmerson Merlin; BARROSO, Luís Roberto (Coord). Doutrinas essenciais de direito constitucional. v. 6. São Paulo: Revista dos Tribunais, 2011, p.742.

32. MASI, Domenico de. A sociedade pós-industrial. 4. ed. Trad. Anna Maria Capovilla. São Paulo: Senac, 2003, p.31: "a passagem de uma fase para a outra não significa uma substituição radical da primeira pela segunda, significa apenas que um elemento se torna central em lugar de outro, o qual perde a própria hegemonia, mas não sua presença e influência”. 
perspectiva histórico-evolutiva da responsabilidade civil, que culminou, no século XXI, em uma sociedade de riscos, provoca a emergência de um sentido ético renovado, e uma racionalidade construtiva, aonde a reparação de danos cede lugar à antecipação de sua ocorrência, através de uma dinâmica prospectiva e funcional. Reconhecer esses novos valores e referenciais significa empregar à responsabilidade civil uma dimensão pujante e a consolidação de novas potências.

\subsection{BREVE APROXIMAÇÃO HISTÓRICO-EVOLUTIVA DA RESPONSABILIDADE CIVIL}

Para conhecer a situação atual de um sistema jurídico, ainda que em suas grandes linhas, é necessário ter uma ideia de seu desenvolvimento histórico, das influências que lhe marcaram as soluções no curso dos tempos. De outro modo, ter-se-á a justaposição de soluções jurídicas, sem que se defina sua estrutura intima. ${ }^{33}$ (Clóvis do Couto e Silva)

Assim como a evolução dos tempos reflete-se na impressão de novos significados às categorias jurídicas essenciais, como o contrato, a propriedade e a família, ${ }^{34}$ também a responsabilidade civil sofre os influxos dos aspectos históricos, sociais e econômicos, variando os elementos para a sua compreensão de acordo com a época e o lugar.

Inegável, nessa ótica, que a transformação dos fundamentos da responsabilidade civil não se origina, tão somente, de alteração legislativa ${ }^{35}$. Convém

33. SILVA, Clóvis do Couto e. O Direito Civil Brasileiro em perspectiva histórica e visão de futuro. In: FRADERA, Vera Maria Jacob de (Org.). O Direito Privado brasileiro na visão de Clóvis do Couto e Silva. Porto Alegre: Livraria do Advogado, 1997, p.11.

34. HIRONAKA, Giselda Maria Fernandes. Responsabilidade pressuposta. Belo Horizonte: Del Rey, 2005, p.117: "Os estatutos fundamentais do novo direito estampam-se com outra feição, rejeitando - ou tornando desimportante - aquela segurança advindo de um sistema centrista e fechado em si mesmo, à volta do indivíduo, e cujo fim era a construção de seu acervo patrimonial, a garantia de sua liberdade contratual e a constituição matrimonializada de sua família. Estampam-se, certamente, na insuperável urgência de restauração da primazia da pessoa humana e expressam-se pelas formulações do trânsito jurídico - calcado na noção de contrato, de obrigações e suas modalidades -, das titularidades fundamentalmente encimadas nas noções de posse e de apropriação de um modo geral - e do projeto parental - que se encontra assentado na noção de família.”

35. BERGEL, Jean-Louis. Teoria geral do direito. São Paulo: Martins Fontes, 2006, p.59, ressalta que "a determinação das fontes do direito é ligada à maneira pela qual o direito é sentido como fenômeno social e às condições sociológicas de sua gestação. $\mathrm{O}$ direito surge da vontade coletiva de grupos 
lembrar que a axiologia que norteia o ordenamento jurídico e o ambiente sociocultural, bem como a sua historicidade, são fundamentais para a formulação de um novo modelo de interpretação jurídica, cuja efetividade depende de sua adequação às necessidades da vida em sociedade.

Disso resulta que a responsabilidade civil repousa suas bases sobre a realidade concreta, dotada de um sentido, não se constituindo necessariamente no produto metódico de procedimentos formais, dedutivos e indutivos. Antes disso, trata-se um produto cultural que absorve valorações. ${ }^{36}$

Nessa esteira de entendimento, a responsabilidade civil pode ser vislumbrada como um processo que se desenvolve na evolução da história, e no qual os fatos (origem), valores (fins que constituem sua razão de ser) e normas (momento culminante) se articulam de forma interdependente e dialética na experiência jurídica, pensamento que fundado no "historicismo-axiológico", originou a célebre Teoria Tridimensional do Direito concebida por Miguel Reale. ${ }^{37}$

Convém, portanto, para a compreensão dos fatores que acenam para o surgimento de uma Responsabilidade Civil Preventiva, realizar uma breve retrospectiva sobre as transformações históricas que influenciaram de maneira incisiva o instituto da responsabilidade civil, considerando-se como recorte temporal na civilização ocidental o período compreendido após a Revolução Industrial.

Ao estudar as transformações da responsabilidade civil no decorrer dos tempos, é fundamental examinar o desenvolvimento econômico e as regras morais que as determinaram. Sobretudo, no caso do Direito civil brasileiro, ressalta-se a grande influência exercida em seu conteúdo tanto pelo Código Napoleão como pela jurisprudência e doutrina francesas, ${ }^{38}$ sem descurar que a organização das matérias do Código Civil de

diversos, não só no seio de uma nação mas também no plano infranacional ou supranacional. Sofre a influência de grupos socioprofissionais, de famílias espirituais, de grupos de pressão diversos...; procede de interesses econômicos, políticos, sociais etc".

36. FERRAZ JÚNIOR, Tércio Sampaio. A ciência do direito. São Paulo: Atlas, 1980, p.38.

37. Teoria Tridimensional do Direito. São Paulo: Saraiva, 1994.

38. Para STOCO, Rui, "cabe advertir que a influência do Código Francês no direito brasileiro decorreu menos do seu texto escrito do que do seu contexto principiológico e axiomático". Estudos em homenagem ao bicentenário do Código Civil francês. Disponível em $<$ http://aplicaext.cjf.jus.br/phpdoc/pages/sen/.../textos.../rui_stoco.doc>. Acesso em: 20 jul. 2013. 
1916 também teve inspiração no Código Civil alemão (BGB), especialmente a opção de divisão em parte geral e parte especial.

Nos sistemas jurídicos integrantes da família romano-germânica, e em especial, no Código Civil francês, que inspirou os códigos civis do século XIX, e seguindo a tradição do Direito romano clássico e a linha de pensamento dos juristas Domat e Pothier, a responsabilidade extracontratual, tendo como fundamento a culpa efetiva e provada, traduzia um modelo de responsabilidade civil adequado à ideologia liberal que representava o paradigma da sociedade moderna - liberdade, igualdade, fraternidade.

No modelo do Código Napoleão, há o predomínio da culpa, e a atenção é voltada ao sujeito que causa do dano, podendo-se enunciar que dos seus artigos $1382 \mathrm{e}$ 1383 decorrem os seguintes princípios fundamentais: a) obrigação geral de responder pelo dano causado a outrem; b) não há responsabilidade sem culpa; c) a culpa tanto pode ser intencional como resultar de negligência ou imprudência; d) sendo a culpa a violação do dever genérico de não causar dano a outrem, ela converte em ilícito o ato executado em tais condições; e) sem dano não há responsabilidade civil; f) a obrigação de responder é uma sanção ressarcitória e não repressiva, que consiste em reparar o dano causado. ${ }^{39}$

No alvorecer do século XX, o ideário solidarista assume um lugar de destaque. Esse movimento iniciou-se na França, com Raymond Salleiles, ao tratar da responsabilidade por acidentes de trabalho e Louis Josserand, ${ }^{40}$ ao discutir a responsabilidade pelo fato das coisas. Ao analisar as posições desses juristas, José de Aguiar Dias identifica:

A doutrina de Salleiles é mais radical do que o sistema proposto por Josserand. Enquanto este se limita a aplicar a teoria objetiva ao fato de coisas inanimadas, aquele prega, sem rodeios, a necessidade de substituir a culpa pela causalidade, mediante a interpretação objetiva da palavra faute no art. 1.382 do Código francês, que, no seu entender, aí não se refere senão ao próprio fato causador do dano, sem indagação ao elemento psicológico do agente. $^{41}$

\footnotetext{
39. ALSINA, Jorge Bustamante. Teoría general de la responsabilidad civil. Buenos Aires: AbeledoPerrot, 1997, p.50-51.

40. Évolution e actualités: conferénces de droit civil. Paris: Recueil Sirey, 1936, p.45.

41. DIAS, José de Aguiar. Da responsabilidade civil. Rio de Janeiro: Renovar, 2006, p.73.
} 
Com efeito, o critério da responsabilidade fundada na culpa não era suficiente para solucionar inúmeras situações lesivas causadas por atividades típicas do capitalismo industrial, geradoras de um notável descompasso entre criadores de risco e aqueles que suportavam os danos originários das atividades de produção - os acidentes. A responsabilidade civil, assim, altera o foco para a perspectiva da reparação do dano, passando o elemento culpa a ser relativizado.

Neste contexto, era evidente que demonstrar a culpa como nexo de imputação levava invariavelmente a injustiças, pois a realidade para a qual foi idealizado o Código Civil francês havia se modificado, em consequência do surgimento de máquinas e produtos perigosos, e fundamentalmente, em função da transformação de um sistema artesanal de produção baseado na agroindústria para um sistema de produção em massa de bens industriais. A noção de risco, portanto, começa a aflorar, em um primeiro momento, vinculada à teoria do risco proveito, ou seja, somente seriam responsáveis independentemente de culpa aqueles que obtivessem proveito de uma atividade, considerando que aquele era limitado ao benefício advindo de uma especulação econômica. $^{42}$

No âmbito jurisprudencial, já em 1896, a Corte de Cassação da França determinou que o patrão indenizasse os danos causados a um empregado pela explosão de uma caldeira, decisão que sob a denominação "Teffaine", ${ }^{43}$ tornou-se mundialmente

42. ALSINA, Jorge Bustamante. Teoría general de la responsabilidad civil. Buenos Aires: AbeledoPerrot, 1997, p.55.

43. Em língua original, Arrêt Veuve Teffaine, Cour de Cassation, Chambre civile, 16 juin 1896: "La Cour; Joint les pourvois; Sur la fin de non-recevoir opposée au second moyen du pourvoi d'Oriolle, pris dans ses deux branches: Attendu que, devant la cour d'appel, Oriolle, sur la demande en garantie dirigée contre lui par Guissez et Cousin, a conclu à la confirmation du jugement par adoption des motifs des premiers juges; que ceux-ci, en rejetant la demande de la veuve Teffaine, ont déclaré l'action de Guissez et Cousin non recevable contre Oriolle par cet unique motif qu'aucune condamnation n'était prononcée contre eux; qu'il suit de là que, quel qu'ait été le système soutenu par Oriolle en première instance, il n'a opposé, devant la cour d'appel, aux conclusions de Guissez et Cousin, aucunes conclusions particulières, confondant sa défense avec la leur contre les prétentions de la veuve Teffaine; [...]Et statuant tant sur le moyen unique du pourvoi formé par Guissez et Cousin que sur le premier moyen du pourvoi d'Oriolle : Attendu que l'arrêt attaqué constate souverainement que l'explosion de la machine du remorqueur à vapeur Marie, qui a causé la mort de Teffaine, est due à un vice de construction; qu'aux termes de l'art. 1384 c. civ., cette constatation, qui exclut le cas fortuit et la force majeure, établit, vis-à-vis de la victime de l'accident, la responsabilité du propriétaire du remorqueur sans qu'il puisse s'y soustraire en prouvant soit la faute du constructeur de la machine, soit le caractère occulte du vice incriminé; D'où il suit qu'en condamnant Guissez et Cousin, propriétaires du Remorqueur Marie, à payer des dommages et intérêts à la veuve et aux enfants Teffaine, ledit arrêt, d'ailleurs motivé, n'a violé aucun des articles visés au pourvoi; Par ces motifs, Rejette." Disponível em $<\mathrm{http}$ ://www.courdecassation.fr/jurisprudence_2/>. Acesso em: 20 jul. 2013. 
famosa, em razão de ter introduzido no Direito francês a noção de risco. ${ }^{44}$ Após essa decisão, em 1896, foi publicada a Lei de Acidentes de Trabalho, estabelecendo uma responsabilidade objetiva em que a vítima não teria que provar a culpa do empregador, contudo, a indenização era limitada (a forfait). Dessa forma, de um modelo de responsabilidade liberal, com o destaque da responsabilidade civil subjetiva, passou-se a um modelo solidarista, com o desenvolvimento da responsabilidade civil objetiva. ${ }^{45}$

Semelhante evolução pode ser observada no Direito brasileiro. ${ }^{46}$ De início, o Código Civil de 1916 era destinado a uma sociedade em grande parte rural, com uma industrialização rudimentar, onde o legislador deu maior importância e realce ao direito de propriedade que aos aspectos sociais, e a análise da responsabilidade civil ocorria sob o prisma da culpa. Foi somente por volta dos anos 30 que a doutrina e jurisprudência brasileiras transformaram a necessidade de prova da culpa à qual se referia o art. $1523^{47}$ do Código de 1916 em presunção juris tantum e posteriormente juris ET de jure, alcançandose, dessa forma, uma responsabilidade objetiva.

$\mathrm{Na}$ atualidade, o Brasil incorpora o modelo solidarista com apoio na Constituição Federal de 1988, nos seus artigos $1^{\circ}$ e $3^{\circ}$. No Código Civil, essa leitura se expressa nas diretrizes que inspiram a codificação - socialidade e eticidade, bem como em diversos artigos espalhados em seu texto legal, ${ }^{48}$ além de inspirar o Código de Defesa do

44. MORAES, Maria Celina Bodin de. Risco, solidariedade e responsabilidade objetiva. In: TEPEDINO, Gustavo; FACHIN, Luiz Edson (coord.). O direito e o tempo: embates jurídicos e utopias contemporâneas. Rio de Janeiro, Renovar, 2008, p.848.

45. GODOY, Cláudio Luiz Bueno de. Responsabilidade civil pelo risco da atividade. São Paulo: Saraiva, 2009, p.14-15, observa que "a mudança foi mesmo de modelo jurídico ou, como observa Stefano Rodotà, uma mudança de dinâmica institucional, mesmo no campo da responsabilidade civil, conformada às modificações constitucionais ocorridas. Do chamado Estado Liberal, passou-se ao que se convencionou denominar Estado Social - verdade que para alguns já mesmo superado pelo Estado Pós-moderno -, de toda sorte que o ordenamento se volta à preservação de valores, de escolhas axiológicas diversas, essencialmente consubstanciadas na dignidade humana, no solidarismo e na justiça da relação entre as pessoas, e ao que o Estado intervém, a cuja garantia e até fomento os mecanismos estatais de atuação, enfim, devem servir".

46. DÍEZ-PICAZO, Luis. Fundamentos del derecho civil patrimonial V: la responsabilidade civil extracontratual. Pamplona: Civitas-Thomson Reuters, 2011, p.103, recorda que: "Las acciones de indemnización por daños fueron históricamente una forma de defensa del derecho de propriedad".

47. Código Civil brasileiro de 1916. Art. 1.523. Excetuadas as do art. 1.521, V, só serão responsáveis as pessoas enumeradas nesse e no art. 1.522, provando-se que elas concorreram para o dano por culpa, ou negligência de sua parte.

48. A título exemplificativo, vide art. 927, parágrafo único, art. 931, art. 932, art. 933, bem como art. 187, do Código Civil. 
Consumidor. ${ }^{49}$ A ênfase se dá na busca não de culpados, mas sim de responsáveis que possam indenizar as suas vítimas.

Na observação de Pietro Trimarchi, ${ }^{50}$ o desenvolvimento das atividades da indústria moderna revelou a insuficiência do princípio da responsabilidade por culpa para assegurar a reparação do dano, inicialmente, porque o exercício de uma produção comporta necessariamente a verificação de uma série de acidentes inevitáveis, inobstante o emprego da máxima diligência. Além disso, em virtude da complexidade da organização empresarial, a causa do dano sofre um considerável fracionamento, em razão da divisão e especificação do trabalho, a ponto de tornar injustificável a responsabilização de um determinado autor. Se o dano não pode ser evitado, deve-se garantir, ao menos, o seu ressarcimento, pelo empreendedor da atividade, posto que este possa empregar medidas que assegurem a não ocorrência do risco, distribuindo os custos destas no total da produção.

Essas razões foram decisivas para a difusão de uma responsabilidade objetiva cujo nexo de imputação é o risco. ${ }^{51}$

Na jurisprudência anglo-saxônica do século passado, especialmente após a conhecida decisão Rylands v. Fletcher, ${ }^{52}$ também ocorre o surgimento de uma figura parecida com a que os sistemas romano-germânicos denominam responsabilidade por riscos - a strict liability, inicialmente aplicada em hipóteses de danos causados por animais ou incêndio, posteriormente aceito no caso de exercício de atividades perigosas, responsabilidade do empregador, até alcançar a sua aplicação mais usual, o defeito do produto (product liability). ${ }^{53}$

49. Por exemplo, art. 12 et seq, do Código de Defesa do Consumidor.

50. Rischio e responsabilità oggettiva. Milano: Dott. A. Giuffrè Editore, 1961, p.13-14.

51. A teoria do risco, por sua vez, pode ser analisada sob o prisma de inúmeros critérios. Para uma análise mais detida acerca destas variações, consulte-se GODOY, Cláudio Luiz Bueno de. Responsabilidade civil pelo risco da atividade. São Paulo: Saraiva, 2009, p.61 et seq.

52. A decisão Rylands v. Fletcher [1868] UKHL 1 (17 July 1868) poderá ser consultada em United Kingdom House of Lords Decisions. Disponível em $<$ http://www.bailii.org/uk/cases/UKHL/1868/1.html>. Acesso em: 20 jul. 2013.

53. MARKESINIS, Basil; DEAKIN, Simon; ANGUS, Johnston. Tort Law. Seventh edition. Oxford: Oxford University Press, 2013, p.503-627 e também TESAURO, Paolo; RECCIA, Giorgio. Origini ed evoluzione del modello dei "torts". In: MACIOCE, Francesco (a cura di). La responsabilità civile nei sistemi di common law. I - Profili generali. Padova: Cedam, 1989, p.155-156. 
Seja na civil law ou na common law, é importante visualizar que a objetivação da responsabilidade conduz a uma visão econômica até então não empregada à responsabilidade civil baseada na culpa, pois os custos do ressarcimento, que tradicionalmente recaiam sobre o causador do dano, são transferidos à coletividade, gerando maior onerosidade aos consumidores, ou a chamada "internalização de externalidades." ${ }^{54}$ Esse enfoque provoca Luis Díez-Picazo ${ }^{55}$ a questionar se os postulados da doutrina do risco obedeceram a uma genuína necessidade do desenvolvimento capitalista - e consequente translação dos custos dos acidentes ao mercado -, ou se o seu surgimento decorre tão somente de simples intuições de equidade.

Paulatinamente, a evolução da objetivação da responsabilidade atingiu contornos ainda mais intensos, chegando-se até mesmo a vislumbrar a ruptura entre a responsabilidade e reparação, especialmente com o desenvolvimento do chamado "Direito de Danos". ${ }^{56}$ Neste, ocorre a translação dos custos da indenização à sociedade mediante o mecanismo da securitização social, o que Guido Calabresi, ${ }^{57}$ identifica como "fracionamento de riscos" ou a criação de fundos específicos que em alguns casos são financiados pelo Estado ou pelos próprios usuários. ${ }^{58}$

Em ocorrências de grande proporção de danos, a eficácia concreta de uma reparação impõe a utilização de mecanismos de seguro de responsabilidade civil, sob pena

54. ALPA, Guido. La responsabilità civile. Parte Generale. Torino: Utet Giuridica, 2010, p.28.

55. Fundamentos del derecho civil patrimonial V: la responsabilidade civil extracontratual. Pamplona: Civitas-Thomson Reuters, 2011, p.114.

56. LOPEZ, Teresa Ancona. Princípio da precaução e evolução da responsabilidade civil. São Paulo: Quartier Latin, 2010, p.53, enfatiza: “[...] na socialização dos riscos perde importância a fundamentação da responsabilidade na teoria da culpa ou do risco. Na verdade, estamos diante do "direito de danos", e não da responsabilidade em sentido estrito".

57. The costs of accidents: a legal and economic analysis. New Haven: Yale Univ Press, 1970, p.63.

58. VARELLA, Marcelo Dias (Org). Responsabilidade e socialização do risco - Estudos do Conselho de Estado Francês. Brasília: UNICEUB e UNITAR, 2006, p.77: “Um dos trunfos dos fundos é separar a questão da responsabilidade daquela da reparação, esta podendo ocorrer quando nenhuma responsabilidade é suscetível de ser determinada ou a determinação da responsabilidade é a priori delicada. Não há desconexão entre o autor do dano e o devedor da indenização; uma vez realizada esta última, a indenização, exceto quando integrando a esfera de direito das vítimas, dispõe de uma ação regressiva de encontro do ou dos responsáveis. Os fundos permitem acordar uma indenização prioritária às vítimas. Eles conjugam, frequentemente, os princípios de responsabilidade e solidariedade, segundo dispositivos de reparação dos riscos que, na realidade, apelam amplamente para os mecanismos de seguro. A maior parte dos fundos mistura, com efeito, indenização automática $a$ priori e ação regressiva de responsabilidade [...] Aspecto importante: os fundos podem permitir um financiamento conjunto Estados/segurados que combine mutualização e solidariedade nacional". 
de insolvência generalizada de responsáveis. Essa indispensável complementação de seguros de responsabilidade geraram, por sua vez, a criação dos "fundos de indenização", que se multiplicaram em setores onde a indenização das vítimas constitui um imperativo de justiça, mesmo na ausência de um causador de dano conhecido, solvente ou segurado.

Referida técnica, que começou a ser aplicada através da indenização de vítimas de acidentes de circulação, também teve ampla repercussão quanto à indenização de vítimas de danos tecnológicos e coletivos, em virtude das dificuldades encontradas na determinação de responsáveis difusos (em que o dano ambiental é excelente exemplo), ou verticalizadas (nas relações empresariais, holdings industriais e filiais situadas em países diversos, como no caso de empresas farmacêuticas); nas hipóteses de danos causados por energia nuclear (acidente de Chernobyl); nas situações de vítimas em série de danos coletivos, dispersas no espaço, cujos danos podem se prolongar no tempo (exemplos sempre lembrados são o "caso Talidomida", o "caso Talco Morhange", e os "Danos do Amianto"). ${ }^{59}$

Essa "socialização do dano", consoante esclarece Geneviève Viney, corresponde à assunção do escopo reparatório do dano por sistemas que garantam o pagamento da indenização ao lesado, quer se trate de sistemas estaduais, de segurança social, da criação de fundos de garantia ou da celebração de contratos de seguro por entidades privadas. Essa autora chega a questionar, inclusive, a coexistência ou destruição da responsabilidade civil tradicional com os regimes de reparação coletiva: "resultados atuais e futuros da coexistência: conciliação ou autodestruição?" 60

Em algumas ousadas iniciativas, a seguridade social passou a desempenhar importância primordial, como no caso paradigmático da edição do Accident Compensation Act, na Nova Zelândia, em 1970, em que cabia ao Estado, típico Welfare State, zelar pela indenização das vítimas, dispensada a instauração de lides processuais. Esse modelo, com atenuações, também foi seguido por outros países escandinavos, como Suécia, Noruega e

59. LAMBERT-FAIVRE, Yvonne. L'evolution de la responsabilité civile d'une dette de responsabilité à une créance d'indemnisation. Revue Trimestrielle de Droit Civil. Paris. v.86. n.1. p.1-20. jan./mar. 1987, p.7.

60. Le déclin de la responsabilité individuelle. Paris: Librairie Générale de Droit et de Jurisprudence, 1965, p.147. Em língua original: "resultats actuels et a venir de la coexistence: conciliation ou interdestruction?" 
Dinamarca, porém, ao longo dos anos, demonstrou-se a necessidade de revisão de diversos preceitos, para a estabilização de déficit governamental gerado pelo pagamento dos seguros. $^{61}$

Embora tenha o condão de garantir o recebimento da indenização, em homenagem aos valores da solidariedade social e dignidade humana, inúmeras críticas, entretanto, são dirigidas à socialização dos riscos. Pode-se destacar, inicialmente, com o apoio de Marco Fábio Morsello, ${ }^{62}$ que a criação de fundos advindos dos agentes criadores de risco e geridos pelo Estado ocasionaria a possibilidade de spreading no âmbito da relação custo/preço, em detrimento do consumidor final.

Contudo, o efeito mais perverso ${ }^{63}$ da socialização dos riscos é a diluição de uma importante função da responsabilidade civil, a prevenção de danos. Isto porque, uma natural diligência da pessoa ciente que arcará com a indenização dos prejuízos decorrentes de danos por ela ocasionados são consideravelmente restringidas pela ausência de consequências patrimoniais relevantes em seu patrimônio, decorrente do pagamento dos prejuízos por uma companhia seguradora, fundos públicos ou privados ou seguridade social. $^{64}$

Essa percepção, dominante na atualidade, já era sentida por René Savatier, ${ }^{65}$ ao tratar das vantagens e inconvenientes da amortização dos riscos na sociedade, através da securitização. Semelhante entendimento é adotado por Teresa Ancona Lopez, ao afirmar que "a ampla 'socialização dos riscos' pode tirar o incentivo da tomada de precaução

61. MORSELlO, Marco Fábio. A responsabilidade civil e a socialização dos riscos. Revista da Escola Paulista da Magistratura, Ano 7. N. 2. Jul/Dez. 2006, p.18.

62. Op.cit., p.19.

63. Nesse sentido, NORONHA, Fernando. Direito das obrigações. Vol. 1. $2^{\text {a }}$ ed. São Paulo: Saraiva, 2007, p.547.

64. Os "efeitos colaterais" do modelo solidarístico, quais sejam, a repartição de custos suportados pela coletividade com o aumento dos preços dos produtos e serviços, além do efeito de irresponsabilização psicológica do autor do dano, também são apontados por ANUNZIATA, Gaetano. Responsabilità civile e risarcibilità del danno. Padova: CEDAM, 2010, p.23.

65. Les métamorphoses économiques et sociales du droit civil aujourd'hui. In: CARVAL, Suzanne. La Construction de la responsabilité civile: controverses doctrinales. Paris: PUF, 2001, p.330. Em língua original: "La loi la plus générale est celle du moindre effort. Or, il est clair qu'on mettra moins d'attention et de zèle à éviter un accident si celui-ci doit être réparé par le corps social, que si l'on doit subir, personnellement, les conséquences de as faute". Tradução livre: “A regra geral é a lei do menor esforço. É claro que nós teremos menor atenção e zelo para evitar um acidente se ele for ser reparado pelo corpo social, do que se sofrermos pessoalmente as consequências da culpa" 
diante dos riscos e da prevenção dos perigos. Sem dúvida, o seguro é o oposto da prevenção". 66

De todo o exposto, forçoso é reconhecer que no final do século XIX, a multiplicação de uma nova espécie de danos, os acidentes, ressaltou a insuficiência de uma responsabilidade fundada exclusivamente na culpa, e provocou o surgimento de uma responsabilidade independente de culpa, originária do risco. Essa responsabilidade objetiva, por sua vez, não substituiu a responsabilidade subjetiva, e sim alargou o espectro de atuação da responsabilização. Não obstante a responsabilidade subjetiva corresponda a um modelo estatal liberal, enquanto a responsabilidade objetiva se amolde aos contornos de um estado social, bem como a primeira seja fundada em um conceito de justiça retributiva ou comutativa, enquanto a segunda se identifique com a concepção de justiça distributiva, é possível vislumbrar um sistema dualista de responsabilidade, em que culpa e risco, embora mantendo âmbitos de atuação distintos, convivem em harmonia. ${ }^{67}$

Até mesmo o desenvolvimento do "Direito de Danos" não foi capaz de extinguir o sistema clássico de responsabilização civil, pois em grande parte dos países que utilizam a socialização dos riscos, os seguros sociais estão fulcrados em patamar-limite, o que não impossibilita ao lesado buscar a indenização dos danos, de forma complementar ou regressiva, em prestígio ao Princípio da Reparação Integral e à função dissuasória da indenização, de que é exemplo, no Brasil, o Seguro Obrigatório de Danos Pessoais (DPVAT).

O foco da questão, de acordo com a observação de Patrice Jourdain, ${ }^{68}$ é

66. Princípio da precaução e evolução da responsabilidade civil. São Paulo: Quartier Latin, 2010, p.55.

67. MORAES, Maria Celina Bodin de. Risco, solidariedade e responsabilidade objetiva. In: TEPEDINO, Gustavo; FACHIN, Luiz Edson (coord.). O direito e o tempo: embates jurídicos e utopias contemporâneas. Rio de Janeiro, Renovar, 2008, p.860.

68. Les principes de la responsabilitè civile. Paris: Dalloz, 2000, p.26: 'Il apparaît aujourd'hui qu'aucune technique d'indemnisation des dommages n'est exclusive des autres (...) Le problème qui se pose est dès lors de délimiter les domaines respectifs des différentes techniques de réparation en fonction de la nature et des sources de préjudices. (...) Plusieurs systèmes sont envisageables. La prise en charge par la Sécurité sociale (ou par des fonds publics) est possible, mais son coût conduirait vraisemblablement à la limiter à certains types d'accidents correspondant à des risques sociaux auxquels toute la population se trouve exposée et sans doute, pour ceux-ci, à la restreindre aux seuls dommages corporels. Une réparation forfaitaire partielle serait difficilement évitable; mais la responsabilité individuelle de l'auteur pourrait alors compléter l'indemnisation en cas de faute grave de celui-ci et en toute hypothèse une assurance individuelle souscrite par la victime lui permettrait également de percevoir un complément d'indemnité". 
delimitar os domínios respectivos de diferentes técnicas de reparação em função da natureza e espécies de danos, cabendo recorrer à seguridade social ou fundos públicos de reparação quando certos tipos de acidentes correspondam à riscos sociais que exponham toda uma população, especialmente no caso de danos à saúde (dommages corporels).

No Brasil, é sabido que o mercado de seguros privados, fundos públicos e seguridade social ainda estão longe de alcançar o avanço verificado em países europeus e Estados Unidos, o que evidencia ainda a proeminência de um sistema tradicional de responsabilidade civil, seja por demandas individuais ou ações coletivas, neste caso, propostas pelo Ministério Público, associações, Defensoria Pública, entre outros. ${ }^{69}$

A evolução prossegue. A partir do final do século XX, surge uma maior consciência acerca das proporções que o moderno capitalismo social e o avançado desenvolvimento científico e tecnológico deixaram para a sociedade do século XXI, e ao mesmo tempo, constata-se a impropriedade em lidar com os seus efeitos - os riscos, sejam potenciais ou efetivos, com certezas provisórias e consequências desconhecidas -, conforme detectado com maestria pelo sociólogo alemão Ulrich Beck. ${ }^{70}$

Esses novos riscos, cujas dimensões danosas são elevadas, provocam uma reação mais consistente em diversos ordenamentos jurídicos, contudo, a lógica da responsabilidade permanece retrospectiva e reparatória. Na Itália, por exemplo, emprega-se a noção de "exposição ao perigo", prevista no art. 2.050 do Código Italiano, como critério informativo de uma responsabilidade agravada. Os franceses, por sua vez, apesar de não terem uma regra semelhante ao princípio da mise en danger italiano como critério de imputação de danos, criaram leis especiais para tratar de situações de danos que decorrem dos altos riscos originários do avanço de tecnologias de ponta. Nesse aspecto, Giovanna Visintini rememora casos de grande repercussão, que levaram a União Europeia a elaborar

69. LEVY, Daniel Andrade. Responsabilidade civil: de um Direito dos Danos a um Direito das Condutas Lesivas. São Paulo: Atlas, 2012, p.198 e 225.

70. Sociedade de risco: rumo a uma outra modernidade. São Paulo: Ed. 34, 2010, p.23. Acresce o sociólogo que, "o processo de modernização torna-se "reflexivo", convertendo-se a si mesmo em tema e problema. Às questões do desenvolvimento e do emprego de tecnologias (no âmbito da natureza, da sociedade e da personalidade) sobrepõem-se questões do "manejo" político e científico administração, descoberta, integração, prevenção, acobertamento - dos riscos de tecnologias efetiva ou potencialmente empregáveis, tendo em vista horizontes de relevância a serem especificamente definidos. A promessa de segurança avança com os riscos e precisa ser, diante de uma esfera pública alerta e crítica, continuamente reforçada por meio de intervenções cosméticas ou efetivas no desenvolvimento técnico-econômico". 
Diretiva $^{71}$ em matéria de responsabilidade decorrente dos produtos defeituosos, como o "caso Seveso" (vazamento de dioxina do tanque de armazenagem de uma indústria química que causou a morte de 3.000 animais e sacrifício de outros 70.000 para evitar a contaminação da substância na cadeia alimentar), acidentes nucleares, danos por explosão de petróleo, incêndio de materiais tóxicos, acidentes de circulação de veículos e ainda, o “caso Talidomida" (medicamento prescrito a mulheres grávidas, nos anos cinquenta, causador de malformação fetal). ${ }^{72}$

Impõe-se recordar que, até esse momento, ainda sob inspiração do positivismo do século XIX, a responsabilidade civil albergava prioritariamente as funções reparatória ou compensatória do dano. Contudo, diante de danos graves e irreversíveis, como os acima exemplificados, Teresa Ancona Lopez questiona: "a responsabilidade civil somente compensatória não consegue cumprir o seu papel, pois se o dano é irreversível, como se poderá fazer justiça pela simples indenização"? ${ }^{73}$ A mesma indagação é aplicável às hipóteses de socialização do risco cobertas por fundos de reparação, cujos mecanismos operam em sentido retrospectivo, permanecendo, contudo, a gravidade e irreversibilidade do dano.

Em tempos atuais, juristas ${ }^{74}$ e a própria legislação ${ }^{75}$ indicam a tendência de alargamento das funções da responsabilidade civil, para abrigar também a função preventiva, e conforme antecipa Geneviève Viney, a transformação que afetará esse instituto ao longo do século XXI, “deverá diversificar suas funções integrando os imperativos de dissuasão e de prevenção que foram um tanto negligenciados até o presente.

71. Directiva 85/374/CEE, de 25 de Julho de 1985, relativa às disposições legislativas, regulamentares e administrativas dos Estados-Membros em matéria de responsabilidade decorrente dos produtos defeituosos. $\quad$ Disponível em $<$ http://eurlex.europa.eu/LexUriServ/LexUriServ.do?uri=CELEX:31985L0374:pt:HTML>. Acesso em: 20 jul. 2013.

72. Principi generali nella disciplina dei fatti illeciti e nuove aree di applicazione della responsabilità civile. In: VISINTINI, Giovanna (coord.). Dieci lezioni di diritto civile. Milano: Giuffrè, 2001, p.218-219.

73. Princípio da Precaução e Evolução da Responsabilidade Civil. São Paulo: Quartier Latin, 2010, p.17.

74. A multifuncionalidade da responsabilidade civil na pós-modernidade, sob o enfoque de diversos doutrinadores, será objeto do capítulo 2, infra.

75. Como exemplo, entre outras, a Lei n ${ }^{\circ}$ 12.608, de 10 de abril de 2012, que institui a Política Nacional de Proteção e Defesa Civil e autoriza a criação de sistema de informações e monitoramento de desastres; Lei 12.305, de 02 de agosto de 2010, que institui a Política Nacional de Resíduos Sólidos. 
Em outras palavras, será preciso que vista uma nova pele". ${ }^{76}$

Nesse ponto, convém atentar que por influência dos princípios da precaução e da prevenção, ${ }^{77}$ é possível vislumbrar um terceiro estágio na evolução da responsabilidade civil, de acordo com Catherine Thibierge:

Alguns autores perceberam, desde o fim do século passado, a emergência de um terceiro tempo da responsabilidade: de uma responsabilidade-sanção, fundada na imputação de culpa e centralizada sobre o autor e seu comportamento causador de dano, dominante no século XIX, sucedida - porém não substituída - por uma responsabilidade-indenização, fundada no risco e centralizada na vítima e no dano sofrido, que marcaram o século XX, estaria em vias de surgir - sem, evidentemente, substituir as duas precedentes -, uma responsabilidade-antecipação, fundada na prevenção de riscos maiores e na preservação dos interesses ambientais e bioéticos, centralizada nas gerações atuais e futuras, e mais amplamente no ser vivo. ${ }^{78}$

É justamente a constatação de que os danos típicos da sociedade pósmoderna, por suas graves repercussões, antes de serem reparados ou compensados, merecem plena e eficaz prevenção, que faz emergir uma nova ética de responsabilidade nas ciências, tecnologia e direito, de que resulta a formulação jurídica de um dever de segurança, e culmina na ampliação de atuação da responsabilidade civil, agora informada também pelos princípios da precaução e da prevenção, não mais restrita unicamente às ações do passado. $^{79}$

76. As tendências atuais do Direito da Responsabilidade Civil. In: TEPEDINO, Gustavo. Direito civil contemporâneo: novos problemas à luz da legalidade constitucional. São Paulo: Atlas, 2008, p.56.

77. Os princípios da precaução e da prevenção, estruturantes da Responsabilidade Civil Preventiva, serão tratados na Parte 2, Capítulo 1, infra.

78. Tradução livre. THIBIERGE, Catherine. Avenir de la responsabilité, responsabilité de l'avenir. Recueil Dalloz. Paris. $n^{\circ}$ 9. p.577-582. mars/2004, p.581. Em língua original: "Quelques auteurs ont perçu, dès la fin du siècle précédant, l'émergence d'un troisième temps de la responsabilité: à une responsabiitésanction, fondée sur l'imputation d'une faute et centrée sur l'auteur et son comportement dommageable, dominante au XIXe siècle relayée - mais non remplacée - par une responsabilitéindemnisation, fondée sur le risque et centrée sur la victime et sur le dommage subi, ayant marqué le Xxe siècle, serait en voie de succéder - sans bien sûr se substituer aux deux précédentes-, une responsabilité-anticipation, fondée sur la prévention des risques majeurs et sur la préservation des intérêts environnmentaux et bioéthiques, et centrée sur les générations actuelles et futures, et plus largement sur le vivant."

79. LAMBERT-FAIVRE, Yvonne. L'éthique de la responsabilité. Revue Trimestrielle de Droit Civil. Paris. v.97. n.1.janv./mar. 1998, p.8. 


\subsection{CRISE DA MODERNIDADE REFLEXIVA: A SOCIEDADE GLOBAL DE RISCO}

Na conhecida obra Risikogesellschaft, ${ }^{80}$ publicada na Alemanha em 1986, o sociólogo Ulrich Beck alertou para o fato de que a sociedade industrial da época moderna estava passando por transformações profundas que não resultavam de forças exteriores ao processo produtivo ou de revoluções sociais, mas constituíam-se o próprio reflexo da modernização simples ou industrial.

Por essa razão, esse processo foi compreendido como "modernização reflexiva" ou "segunda modernidade", na qual são evidenciadas as antinomias ou insuficiências da primeira modernidade ou, em outras palavras, a "era dos efeitos colaterais" ${ }^{81}$ (ou reflexivos), produtor de contingências incontroláveis que não podem ser abarcadas ou cobertas pelo cálculo do risco e do seguro, pois essas ameaças incalculáveis eliminam qualquer racionalidade instrumental e assinalam o retorno da incerteza.

Os riscos da modernidade reflexiva, impossíveis de bloquear, não constituem um evento apenas local ou limitado no tempo, ao contrário, o futuro é integrado ao presente e os riscos ultrapassam as fronteiras nacionais em intensa globalização. Os danos à natureza são socializados, o consumo cotidiano de itens indispensáveis, como comida, água, medicamentos e utensílios domésticos escondem perigos os quais ninguém pode subtrair-se.

Vinte anos após, em 2007, Ulrich Beck publicou Weltrisikogesellschaft, ${ }^{82}$ obra que retoma a temática dos riscos para defender o conceito de uma sociedade global de risco. Durante as duas décadas posteriores à obra que inaugurou uma maneira singular de perceber a sociedade contemporânea, os riscos evidenciados pelo sociólogo alemão assumiram novas formas e significados, sendo que a publicação mais recente caracteriza,

80. Com tradução em língua portuguesa: BECK, Ulrich. Sociedade de risco: rumo a uma outra modernidade. Trad. Sebastião Nascimento. São Paulo: Ed. 34, 2010.

81. BECK, Ulrich. Autodissolução e auto-risco da sociedade industrial: o que isso significa? In: BECK, Ulrich; GIDDENS, Anthony, LASH, Scott. Modernização reflexiva: política, tradição e estética na ordem social moderna. Trad. Magda Lopes. São Paulo: Editora da Universidade Estadual Paulista, 1997, p.208.

82. A tradução em inglês foi publicada em 2009: BECK, Ulrich. World at risk. Translated by Ciaran Cronin. Cambridge: Polity Press, 2009. 
de certa forma, uma continuidade teórica do livro precedente, indicativo de novos quadros de referência.

Dentro dessa última análise, são enumerados três tipos de riscos globais, não exaustivos: os riscos de crises ecológicas - o cenário político foi forçado a reconhecer que as mudanças climáticas não resultam de mera especulação; os riscos de crises financeiras globais - que provocam efeitos mundiais de difícil controle; e o risco de ameaças terroristas - que se deslocaram para a arena global. Os dois primeiros, são riscos percebidos como colaterais ou acidentais, enquanto este último difere-se daqueles por ser intencional.

Diante da permanência da submissão ao risco pela sociedade globalizada, embora aquele possa assumir no tempo diversas tipologias, Ulrick Beck ${ }^{83}$ apresenta dois importantes conceitos ou constatações, que alertam para uma atuação preventiva, o que ressalta o interesse do seu estudo para a presente pesquisa.

O primeiro deles é a análise distintiva entre risco e catástrofe. Risco é a antecipação da catástrofe. O primeiro, não possui concretude espaço-temporal ou social; a segunda possui incidência no tempo e no espaço. Assim, de que forma o risco, que é um acontecimento futuro, pode ser antecipado, de forma a orientar as expectativas, ações, e forças políticas? A resposta do sociólogo é de que, através da encenação dos riscos globais, o futuro de catástrofes é percebido em tempo presente, com o objetivo de evitá-las, o que demarca uma grande influência sobre decisões atuais.

O segundo, é a eliminação da distinção entre risco e a percepção cultural do risco. A concepção racionalista do risco trabalha com o risco objetivo, calculado e medido por especialistas, e a percepção cultural do risco ocorre em situações aonde há insuficiência de informações ou crenças antagônicas sobre os riscos. Beck defende que a encenação do risco faz desaparecer a distinção entre realidade objetiva e percepção cultural, pois, não sendo o risco uma grandeza mensurável, a sua realidade reside justamente no caráter duvidoso. Assim, a exigência de um critério objetivo, segundo o qual o risco pode ser medido em graus, não leva em consideração que somente após uma determinada percepção é que os riscos são considerados urgentes e reais ou desprezíveis e

83. World at risk. Translated by Ciaran Cronin. Cambridge: Polity Press, 2009, p.30 et seq. 
fictícios. Disso decorre que saber se vivemos em um mundo objetivamente seguro não é fundamental, pois o que importa é que a encenação de riscos antecipados obrigue a uma ação.

Todos os elementos acima apontados indicam o conteúdo de uma nova dinâmica estrutural da sociedade no Século XXI - a sociedade global de risco, cujo norte reside na antecipação da catástrofe, capaz de alterar radicalmente o futuro da política global, o que Beck denomina "cosmopolitan material politics":

O mundo não é o que parece ser; enquanto sua existência e seu futuro dependem de decisões, decisões que desempenham aspectos positivos e negativos reciprocamente, que conectam o progresso e o declínio e que, como todas as coisas humanas, são portadoras de erro, ignorância, arrogância, promessa de controle e em última análise, até mesmo a semente de uma possível autodestruição. ${ }^{84}$

O risco, na semântica atual, revela duas faces - oportunidade e perigo, e essa ambivalência requer uma decisão que trata com incertezas e atua no domínio do provável e do plausível. Diante desse aspecto, os valores culturais influenciam fortemente a política preventiva ou precautória e a possibilidade de controle através de instrumentos jurídicos. Como exemplo, percebe-se que na Europa há o predomínio de medidas restritivas à utilização de alimentos geneticamente modificados (OGM), ao contrário dos Estados Unidos. Esse país, por sua vez, trata com exacerbado rigor os possíveis riscos decorrentes de terrorismo, o que não é percebido com tanta veemência em qualquer outra nação do mundo.

Portanto, a consciência e formas de gestão dos riscos estão estreitamente relacionadas às construções sociais, que podem empregar interpretações conflitantes, exageradas ou minimizadas, de acordo com interesses e pontos de vista diversos, como formas de expressão contemporânea de valores.

A percepção dos riscos de alcance global e o reconhecimento da condição de vulnerabilidade mundial, por sua vez, modifica o olhar sobre a sociedade e dá lugar a

84. Tradução livre. Na versão em inglês: "The world is not as it is; rather its existence and its future depend on decisions, decisions which play off positive and negative aspects against one another, which connect progress and decline and which, like all things human, are bearers of error, ignorance, hubris, the promise of control and, ultimately, even the seed of possible self-destruction". BECK, Ulrich. World at risk. Translated by Ciaran Cronin. Cambridge: Polity Press, 2009, p.4. 
uma reconstrução em termos sociais, políticos, jurídicos, bem como origina um sentido ético conexo com a relação presente e futuro e a preservação da vida e humanidade: "é esse fato que torna a disputa em torno de medições, valores máximos aceitáveis e efeitos de curto e longo prazo, algo candente para a própria existência", ${ }^{85}$

Essa verificabilidade quanto à transformação do risco, projeta-se também como causa eficiente para a alteração de diversos institutos, para a inerente gestão, mitigação e prevenção, dentre eles a responsabilidade civil, que de uma visão centrada nos sujeitos e interesses individuais, passa a integrar um sistema que deve estar apto a lidar com conflitos policontextuais, ${ }^{86}$ integrando aspectos econômicos, políticos, jurídicos, sociais, tecnológicos, científicos, teleológicos, entre outros, inaugurando, assim, uma dimensão sistêmica da responsabilidade civil, cuja diretriz é fornecida pelos princípios da precaução e da prevenção, conforme adiante será tratado no presente estudo. Ademais, há o redimensionamento da dignidade da pessoa humana e consequentemente, dos direitos personalíssimos, do direito à vida, do usufruto de propriedade e da saúde, de uma dimensão individualista em direção a um sentido transindividual, a fim de assegurá-los de forma intrageracional (gerações presentes), e também intergeracional (futuras gerações).

Esse tempo compreendido como pós-moderno traz ao debate contemporâneo o discurso sobre as regras que o legitimam, ${ }^{87}$ e consegue manter um discurso prospectivo a favor da humanidade, com o enaltecimento dos direitos humanos e defesa do meio ambiente. Contudo, não se desprende do globalismo, ${ }^{88}$ que por sua vez, traz um aspecto puramente econômico, o que é um incessante problema atinente ao risco e

85. BECK, Ulrich. Sociedade de risco: rumo a uma outra modernidade. Trad. Sebastião Nascimento. São Paulo: Ed. 34, 2010, p.09.

86. Para aprofundamento, consulte-se TEUBNER, Gunther. Direito, sistema e policontexturalidade. São Paulo: Unimep, 2005.

87. LYOTARD, Jean-François. O pós-moderno. $3^{\mathrm{a}}$ ed. Trad. Ricardo Corrêa Barbosa. Rio de Janeiro: José Olympio Editora, 1998, p.100: "O traço surpreendente do saber pós-moderno é a imanência a si mesmo, mas explícita, do discurso sobre as regras que o legitimam”.

88. BECK, Ulrich. O que é globalização? Equívocos do globalismo: respostas à globalização. Trad. André Carone. São Paulo: Paz e Terra, 1999, p.211: “Trata-se, consequentemente, de uma sociedade de risco que confere poder às empresas transnacionais. Não é a 'desgraça real' do sucesso da globalização econômica - como, por exemplo, o deslocamento dos postos de trabalho para países com mão de obra barata -, mas, sobretudo esta ameaça e sua difusão que atiçam o medo, intimidam e terminam por obrigar os adversários políticos e sindicais a fazer aquilo que a disponibilidade de investimentos exige em nome de sua sobrevivência, para evitar algo mais danoso. A hegemonia semântica, a ideologia publicamente defendida pelo globalismo é uma fonte de poder a partir do qual as empresas adquirem seu potencial estratégico". 
à comercialização do risco.

Disso decorre a incerteza no quotidiano da sociedade e com ela a necessidade de meios para reduzir sua complexidade e precavê-la, pois o medo, de que nos fala Zygmunt Bauman, ${ }^{89}$ está umbilicalmente relacionado ao futuro.

Todos esses fatores demonstram a carência de uma ética que se renova, não no sentido do préstimo individual e caridoso, e sim justificados em novas fontes, particularmente na conjunção exposta por Edgar Morin, entre responsabilidadesolidariedade. ${ }^{90}$

De tal sorte, frente à sociedade global de riscos e diante da complexidade do equacionamento dos riscos admissíveis ou não, busca-se uma nova ética social e um novo sentido de responsabilidade, o que será exposto no capítulo a seguir.

\subsection{A RESPONSABILIDADE COMO DEVER DA ÉTICA CONTEMPORÂNEA}

Kant $^{91}$ constrói a sua fundamentação filosófica em três virtudes, que ainda hoje são condições indispensáveis ao fomento científico e à cognoscibilidade da sociedade

89. Medo líquido. Trad. Carlos Alberto Medeiros. Rio de Janeiro: Jorge Zahar, 2008, p.10. Para a noção de tipos de medo: "O que mais amedronta é a ubiquidade dos medos; eles podem vazar de qualquer canto ou fresta de nossos lares e de nosso planeta. Das ruas escuras ou das telas luminosas dos televisores. De nossos quartos e de nossas cozinhas. De nossos locais de trabalho e do metrô que tomamos pra ir e voltar. De pessoas que encontramos e de pessoas que não conseguimos perceber. De algo que ingerimos e de algo com o qual nossos corpos entraram em contato. Do que chamamos de natureza (pronta, como dificilmente antes em nossa memória, a devastar nossos lares e empregos e ameaçando a destruir nossos corpos com a proliferação de terremotos, inundações, furacões, deslizamentos, secas e antes em nossa memória, a devastar nossos lares e empregos e ameaçando destruir nossos corpos com a súbita abundância de atrocidades terroristas, crimes violentos, agressões sexuais, comida envenenada, água ou ar poluídos)".

90. MORIN, Edgar. O método 6: ética. Trad. Juremir Machado da Silva. Porto Alegre: Sulina, 2007, p.28: "A crise da ética da nossa época é, ao mesmo tempo, crise da religação indivíduo/sociedade/espécie. Importa refundar a ética; regenerar suas fontes de responsabilidade-solidariedade significa, ao mesmo tempo, regenerar o circuito de religação indivíduo-espécie-sociedade na e pela regeneração de cada uma dessas instâncias. Essa regeneração pode partir do despertar interior da consciência moral, do surgimento de uma fé ou de uma esperança, de uma crise, de um sofrimento, de um amor e, hoje, do chamado vindo vazio ético, da necessidade que vem da deterioração da ética. Não se trata, portanto, para nós de encontrar um novo fundamento para a ética, mas, ao mesmo tempo, de dar-lhe novas fontes, novas energias e de regenerá-la”.

91. KANT, Immanuel. Fundamentação da metafísica dos costumes. Trad. Paulo Quintela. São Paulo: Abril Cultural, 1980, p.101-162. 
e da humanidade. São elas: a física - a instância da natureza, a lógica - forma de conhecimento e, sobretudo, a ética como o mundo dos comportamentos humanos que, iniciando-se com preceitos altruísticos, como amor e amizade acabaram ao longo da jornada da civilização sendo matriz de diversas ciências e áreas da sociedade, nelas incluindo o Direito, a economia, a moral, a política, entre outras.

Assim, na dogmática da responsabilidade civil, o ethos fornece novo sentido, demonstrando hoje a insuficiência do modelo simplesmente retrospectivo, ou seja, reparatório, e abre campo para a função antecipatória da ocorrência de dano, sobretudo considerando certos danos não passíveis de serem sequer reparados ou compensados. Franz Wieacker, ${ }^{92}$ atento a essa dimensão, ao analisar a relação entre o direito privado e a sociedade industrial, reconhece que para a realização da justiça, o jurista deve reconhecer o ethos social, que na sociedade burguesa do século XIX correspondia à liberdade, sendo substituída, posteriormente, pela responsabilidade.

A evolução científica e tecnológica que levou o homem à sociedade global de riscos, pleno de certezas provisórias ou incertezas constantes, em incessante mutação, conferiu poderes de vida ou morte à humanidade contemporânea, em razão da amplitude espacial e temporal de suas ações. É justamente esse distanciamento entre as ações presentes e suas consequências futuras e a visão mecanicista amparada no ideal libertário, que em determinado momento contribuíram para que o homem não se sentisse responsável pelos efeitos dos seus atos, ausente qualquer sentimento de responsabilidade solidária.

A necessidade de gestão e controle do conhecimento gerado pela sociedade moderna estimulou a necessidade de uma abordagem ética acerca dos riscos sociais, para o estabelecimento de limites que, em outro momento, sejam materializados por instrumentos jurídicos, com um novo sentido de responsabilidade. Essa discussão, embora apresente dificuldades decorrentes do pluralismo de grupos sociais e da interdisciplinaridade de matérias, é caminho indispensável para a não realização de práticas que produzam consequências irreversíveis.

Nessa trilha, diversos filósofos tomaram por objeto de investigação a

92. Diritto Privato e società industriale. Trad. Gianfranco Liberati. Napoli: Edizione Scientifiche Italiane, 1983, p.38. 
intersecção entre ética e responsabilidade na sociedade contemporânea, cujos pensamentos centrais serão expostos a seguir.

Essa temática foi tratada por Edgard Morin, ${ }^{93}$ que propõe em seus estudos tanto a modificação das fontes da ética em nível individual como em nível planetário. $\mathrm{Na}$ primeira vertente, após transcorrer sobre a ética da honra, cujo fim é evitar pessoalmente as disfunções entre gestos e intenções, discorre quanto à ética da responsabilidade, na qual a autonomia do indivíduo tem necessária interface com a solidariedade, considerando que as situações desenvolvem-se em plexos comunitários. ${ }^{94} \mathrm{Na}$ segunda vertente evidencia que o pertencimento de todos a esta Terra-Pátria faz emergir direitos e instâncias planetárias capazes de enfrentar problemas vitais, surgindo políticas de civilização que substituam modelos tão só de desenvolvimento, dando mostras efetivamente de um caminho que permita à humanidade chegar numa sociedade-mundo para além da idade de ferro planetária.

O desenvolvimento das ciências, de maneira geral, no século XX apontou problemas éticos decorrentes de múltiplos poderes de manipulação, o que impõe um controle político sobre novas técnicas e descobertas científicas. ${ }^{95}$ Para tanto, Morin ${ }^{96}$ aponta a necessidade epistemológica de romper os limites do determinismo universal e simplificação, dogmas a serem ultrapassados, e absorver a probabilidade e a incerteza como medidas indispensáveis à captação da realidade. Por outras palavras, é necessário encaixar o conhecimento em um contexto global, sistemático, circular e dialógico, rejuntando fenômenos e rejeitando a causalidade linear, típica do pensamento clássico este é o desafio da complexidade.

Rejeitando a ideia de que o pensamento complexo e o reconhecimento da incerteza (contradição entre o princípio do risco e o princípio da precaução) desencoraja a

93. O método 6: ética. Trad. Juremir Machado da Silva. Porto Alegre: Sulina, 2007, p.166.

94. Op.cit, p.100: “A consciência de responsabilidade é característica de um indivíduo-sujeito dotado de autonomia (dependente como toda autonomia). A responsabilidade, contudo, necessita ser irrigada pelo sentido de solidariedade, ou seja, de pertencimento a uma comunidade".

95. MORIN, Edgard. Ciência com consciência. $8^{\mathrm{a}}$ ed. Trad. Maria D. Alexandre e Maria Alice Sampaio Dória. Rio de Janeiro: Bertrand, 2005.

96. MORIN, Edgard. Complexidade e ética da solidariedade. In: CASTRO, Gustavo de; CARVALHO, Edgard de Assis; ALMEIDA, Maria da Conceição de. Ensaios de complexidade. $4^{\mathrm{a}}$ ed. Porto Alegre: Sulina, 2006, p.11. 
ação, Morin ${ }^{97}$ defende que com a força da participação, da solidariedade e da comunidade, a própria ação será corrigida para enfrentamento da incerteza, o que constitui um dos "sete saberes indispensáveis da educação do futuro”:

Assim, a resposta às incertezas da ação é constituída pela escolha refletida de uma decisão, a consciência da aposta, a elaboração de uma estratégia que leve em conta as complexidades inerentes às próprias finalidades, que possa se modificar durante a ação em função dos imprevistos, informações, mudanças de contexto e que possa considerar o eventual torpedeamento da ação, que teria tomado uma direção nociva. ${ }^{98}$

Também François Ost $^{99}$ alerta para uma redefinição ética, ao tratar da modificação das condições da ação humana, em um ambiente afetado qualitativamente por situações nunca antes observadas. De uma vivência passiva e condicionada ao acaso, as consequências coletivas virtualmente catastróficas passam a derivar do poder de ação do homem. Por essa razão, cada indivíduo, ao contribuir, mesmo que de forma infinitesimal, para efeitos globais de grande repercussão, atrai para si uma responsabilidade (ou corresponsabilidade) por uma ação coletiva cujas consequências ainda não são totalmente conhecidas.

O peculiar do pensamento de Ost é que ao trabalhar com uma responsabilidade compartilhada, amplia os mecanismos de responsabilização (solidariedade, objetivação) a um número cada vez mais vasto de pessoas. O domínio da ação ética, que classicamente se limitava à esfera das relações de intimidade e proximidade, no contexto da pós-modernidade sofre uma ampliação à escala universal. A responsabilidade estabelece um vínculo entre uma ação e suas consequências, mas ao contrário da configuração pretérita do tradicional pensamento ético e sua institucionalização jurídica (imputabilidade), a ideia de responsabilidade sofre um giro para o futuro, e assume uma tarefa de proteção, ou, nas palavras do jusfilósofo: “em lugar de procurar os culpados das ações passadas, ela serviria para definir o círculo das pessoas solidariamente investidas de novas missões". 100

97. MORIN, Edgard. Op.cit., p.20.

98. MORIN, Edgard. Os sete saberes necessários à educação do futuro. $2^{\mathrm{a}}$ ed. Trad. Catarina Eleonora F. da Silva e Jeanne Sawaya. São Paulo: Cortez; Brasília, DF : UNESCO, 2000, p.91.

99. A natureza à margem da lei: a ecologia à prova do direito. Lisboa: Instituto Piaget, 1995.

100. OST, François. Op.cit., p.309. 
Essa responsabilidade voltada para adiante se refere à transmissão de um patrimônio da humanidade comum às gerações futuras (equidade intergeracional). Os conceitos principais desse modelo de responsabilidade são: responsabilidade-projeto (ao contrário de responsabilidade-imputação); gerações futuras como beneficiários; patrimônio (em dimensão alargada, referente ao meio, à natureza) e humanidade (linha virtualmente infinita).

Nesse ponto, interessa constatar que a concepção de Ost, ao tratar da proteção intergeracional, está diretamente vinculada com a aplicação do princípio da precaução, incentivando o necessário debate acerca da identificação e gestão de riscos e da tentativa de prever as possíveis consequências, com o objetivo de preservar o meio ambiente e o futuro da humanidade.

De igual sorte, Hans Jonas ${ }^{101}$ ressalta a necessidade de atuação sempre e de acordo com a permanência da vida humana, o que origina uma ética ecossocialista (responsável) para evitar que a destruição do meio ambiente não agrida as futuras gerações e nem mesmo a geração atual. Assim, rompendo com a ética tradicional, antropocêntrica, construída com base em direitos e obrigações e fundada na responsabilidade recíproca, a nova ética construída por esse filósofo é erguida em uma responsabilidade voltada para o futuro, fundamentada na globalidade do ser e no imperativo da existência, com fortes reflexos na crise ambiental e no risco tecnológico.

Dessa forma, crente na insuficiência dos imperativos éticos tradicionais diante das novas categorias do agir coletivo da civilização tecnológica, Jonas propõe o Princípio Responsabilidade como uma sistemática tentativa de fundamentar uma ética necessária às interferências sobre a natureza, pois as ações sob o signo da tecnologia possuem um alcance causal e abrangência espaço-temporal que carece de precedentes. Esse poder, até então inexistente, justifica a necessidade de uma ética que vai além do plano individual mas que norteia os atos também no âmbito coletivo e político.

Em tal linha, a ética proposta por Jonas ultrapassa a ética da intersubjetividade elaborada por Kant em seu conhecido imperativo categórico - "Age

101. JONAS, Hans. O princípio responsabilidade: ensaio de uma ética para a civilização ecológica. Rio de Janeiro: Contraponto, Puc Rio, 2006. 
apenas segundo uma máxima tal que possas ao mesmo tempo querer que ela se torne uma lei universal", ${ }^{102}$ e ao buscar uma ponderação sobre o significado da tecnologia sobre a condição moral do homem, elabora uma adaptação do imperativo kantiano - o "imperativo ético" -, vinculado a um novo tipo de ação humana: "Age de tal forma que os efeitos de tua ação sejam compatíveis com a permanência de uma autêntica vida humana sobre a terra". 103

O Princípio Responsabilidade orienta-se, assim, por dois princípios, a "heurística do medo" e o "imperativo ético", ou seja, diante da incerteza e do risco tecnológico, a abordagem a ser observada é sempre de precaução (temor) e cautela (consciência no agir) pois as consequências da ação devem ser sempre avaliadas em função dos seus piores prognósticos. Em consequência, a responsabilidade corresponde a um critério ético que integra as gerações futuras, considerando que a perda da totalidade da vida pela ação se tornou uma possibilidade factível diante das intervenções negativas sobre a natureza.

Tomando-se em conta todos os elementos conceituais elaborados por Jonas, é possível sustentar que no âmbito jurídico, o princípio da precaução é fatalmente influenciado pela "heurística do medo", pois a prudência indica que na existência do risco, para que se evitem futuros danos, a melhor opção é sempre considerar o futuro mais pessimista. Igualmente, ao ressaltar a responsabilidade ética e o cuidado com as gerações futuras, o filósofo criou a base do que direito consolida como Desenvolvimento Sustentável.

Além dos filósofos anteriormente citados, pertinente ainda para a temática dos fundamentos éticos da Responsabilidade Civil Preventiva ressaltar o pensamento de Paul Ricoeur, ${ }^{104}$ ao construir uma análise semântica do conceito de responsabilidade, para que os elementos imputação, solidariedade e risco assumam o lugar mais adequado dentro de uma "paisagem recomposta", qual seja, a realidade social e econômica do final do

102. Fundamentação da metafísica dos costumes. Trad. Paulo Quintela. São Paulo: Abril Cultural, 1980, p.129.

103. JONAS, Hans. O princípio responsabilidade: ensaio de uma ética para a civilização ecológica. Rio de Janeiro: Contraponto, Puc Rio, 2006, p.47-48.

104. RICOEUR, Paul. O justo ou a essência da justiça. Trad. Vasco Casimiro. Lisboa: Instituto Piaget, 1995, p.35 et seq. 
século XX.

A proposta de Ricoeur aproxima-se da de Jonas, ao tornar a responsabilidade o elemento principal da discussão ética da pós-modernidade. Contudo, ao passo que Jonas centraliza as suas preocupações sobre a descoberta da responsabilidade sobre a ação de alguém identificável que tenha causado um dano (imputação no sentido tradicional), Ricoeur sugere uma responsabilidade "social e coletiva" com orientação prospectiva, que tenha como norte a previsibilidade e avaliação das implicações da ação em relação ao futuro. ${ }^{105}$ Essa posição pode-se deduzir, dentre outras passagens significativas, do seguinte excerto de Ricoeur:

A orientação retrospectiva que a ideia moral de responsabilidade tinha em comum com a ideia jurídica, orientação em virtude da qual nós somos eminentemente responsáveis pelo que fizemos, deveria ser substituída por uma orientação mais deliberadamente prospectiva, em função da qual a ideia de prevenção dos prejuízos futuros se juntaria à de reparação dos danos já cometidos. Sobre esta ideia de prevenção tornar-se-ia possível reconstruir uma ideia de responsabilidade que desse resposta aos três motivos de inquietação antes invocados. $^{106}$

No contexto do pensamento de Ricoeur, a responsabilidade civil deve perpassar um "deslocamento" do seu objeto, quer considerando que os riscos acabam sendo compartilhados entre seu causador e o vulnerável, quer considerando o distanciamento no tempo entre a ação prejudicial e os seus efeitos nocivos. Esse deslocamento visa à precaução, prevenção e prudência para a evitabilidade do dano.

A contribuição de Ricoeur para a responsabilidade civil contemporânea é indiscutível, já que torna possível a aplicação do conceito de responsabilidade em dupla dimensão - retrospectiva e prospectiva, e traz novas perspectivas aos obstáculos encontrados na teoria da responsabilidade, ao tentar adaptar uma resposta dogmática clássica aos desafios trazidos pelo desenvolvimento tecnocientífico e sua inerente incerteza e riscos.

De todas as reflexões filosóficas expostas, é possível retirar elementos

105. ALENCASTRO, Mario Sergio. Hans Jonas e a proposta de uma ética para a civilização tecnológica. Desenvolvimento e meio ambiente, n. 19, p.13-27, jan./jun. 2009, p.20.

106. RICOEUR, Paul. Op.cit., p.56. 
comuns que estabeleçam um mínimo ético, revelador de consenso, capaz de nortear o Direito. Desse exercício conclui-se que, diante da transformação ética da sociedade pósmoderna, em que a relação individual-intersubjetiva amplia-se para uma relação coletivaintergeracional, a ética da alteridade e a responsabilidade por outrem de que nos fala Levinas $^{107}$ alcança ampla dimensão. Nesse sentido, o termo responsabilidade reenvia a uma dimensão temporal - o futuro, no qual serão realizados os projetos comuns ao gênero humano.

Ao considerar-se que responsabilidade é não agir ao acaso, mas sim ter bem presente as consequências da ação, em um encadeamento entre liberdade limitada e previsão, ${ }^{108}$ é possível identificar na responsabilidade contemporânea um dever de comportamento, ${ }^{109}$ qual seja, um dever de cuidado que é necessário manter em relação às consequências das próprias ações para com o outro, à coletividade e ao ambiente. Influenciada por uma nova ética, a responsabilidade se apresenta, assim, como um imperativo que obriga à reflexão sobre as consequências das ações, que dessa forma, guia e orienta o comportamento.

Esse fator reflete-se decisivamente na responsabilidade jurídica, pois já não é mais suficiente o simples desvio do dano da vítima para o agente: não se trata do tráfego ou logística do dano, particularmente considerando as potencialidades dos riscos existentes. Os danos devem ser evitados por imposição dos princípios da precaução e da

107. LEVINAS, Emmanuel. Totalidade e Infinito, Coimbra: Edições 70, 2008, p 74: “O outro, na alteridade, é um rosto que se apresenta diante do Eu, em uma relação face à face, e que exige do Eu um comportamento ético que o permita ser, isto é, existir outramente."

108. Ao trabalhar com conceitos da linguagem filosófica, Nicola ABBAGNANO estabelece algumas constantes de significado do verbete Responsabilidade, relacionando-a com a liberdade e com a previsão: "Responsabilidade (...) Possibilidade de prever os efeitos do próprio comportamento e de corrigi-lo com base em tal previsão (...) Na verdade, a noção de R. baseia-se na escolha, e a noção de escolha é essencial ao conceito de liberdade limitada." (Dicionário de Filosofia. Trad. Alfredo Bosi e Ivone Castilho Benedetti. São Paulo: Martins Fontes, 2007, p.855.)

109. HELZEL, Paola B. La nozione di responsabilità baricentro tra etica, diritto e politica. In: CALABRÓ, Gian Pietro (a cura di). La nozione di responsabilità tra teoria e prassi. Milano: CEDAM, 2010, p.29: "La responsabilità, infatti, dovrebbe caratterizzare la condotta individuale indirizzandola verso quel dovere che ogni essere umano ha nei confronti dell'altro, in quanto à un Tu. In questo senso, si può dire che un soggetto è responsabile 'se ha, o aveva, un dovere di comportamento'. In altri termini, come ben suggerisce Viola, 'la responsabilità è il volto che ha assunto il dovere all'interno dell'etica contemporanea". Em tradução livre: "A responsabilidade, de fato, deve caracterizar a conduta individual orientando-a para o dever que todo ser humano tem para com o outro. Neste sentido, podemos dizer que um sujeito é responsável "se possui, ou possuía, um dever de comportamento". Em outras palavras, como bem sugere Viola 'a responsabilidade é o lugar que assumiu o dever dentro da ética contemporânea"”. 
prevenção para que não haja um fim da vítima ou da humanidade, mas exista sempre uma nova chance de começo.

Desenvolve-se, a partir dessas constatações, uma expectativa de reconfiguração do arsenal jurídico capaz de dar uma resposta satisfatória às necessidades de proteção e segurança atuais, a assumir novas funções, a descobrir novos recursos e reexaminar seus próprios fundamentos. Resta clara a importância, conforme apontam Nonet e Selznick, de "tornar a lei mais responsiva às necessidades sociais":

[...] Uma instituição responsiva conserva a capacidade de compreender o que é essencial à sua integridade e ao mesmo tempo leva em consideração as novas forças do ambiente social. Para isso, ela se baseia nas formas pelas quais a integridade e a abertura se sustentam mutuamente, mesmo quando conflitantes. Percebe as pressões sociais como fontes de conhecimento e de oportunidades de autocorreção. Para assumir essa postura, a instituição necessita contar com a diretriz de uma finalidade. Os propósitos determinam padrões para a crítica da prática estabelecida, e com isso indicam direções para a mudança. ${ }^{110}$

Ao se atribuir juridicidade ao valor ético da alteridade, encontra-se o ponto de intersecção entre a Filosofia e o Direito: a solidariedade, estabelecida pelo art. $3^{\circ}$ Constituição Federal de 1988 como objetivo da República Federativa do Brasil. Portanto, a solidariedade, no ordenamento jurídico brasileiro, não é apenas um valor, dependente do exercício da ética. Muito além disso, a solidariedade ganhou autoridade constitucional e deve atuar como vetor interpretativo e essência jurídica das ações estatais e privadas, e especificamente no tocante à Responsabilidade Civil Preventiva, revela-se como um dos seus fundamentos jurídicos.

No que tange à seara ambiental, e já incorporando o substrato ético da responsabilidade contemporânea, Morato Leite e Ely Melo ${ }^{111}$ ressaltam o "princípio da responsabilização" para o enfrentamento dos problemas nesse domínio, exigindo-se a readaptação de alguns mecanismos da responsabilidade civil para fins de combate à degradação ambiental, através de uma configuração remodelada. Esse perfil, que tornaria a

110. NONET, Philippe; SELZNICK Philip.Direito e sociedade: a transição ao sistema jurídico responsivo. Trad. Vera Ribeiro. Rio de Janeiro: Revan, 2010, p.121 e 126.

111. LEITE, José Rubens Morato; MELO, Melissa Ely. As funções preventivas e precaucionais da responsabilidade civil por danos ambientais. Revista Sequência, nº 55, p.195-218, dez. 2007. 
responsabilidade civil um sistema mais apto a trazer segurança à coletividade, inclui: a) a ampliação de funções do instituto, em que o caráter preventivo informado pelos princípios da precaução e da prevenção ganharia destaque, a par do caráter reparatório do dano; b) a inclusão da tutela preventiva de danos na esfera da responsabilidade civil como medida prioritária à reparação; c) a ausência de necessidade da efetiva concretização do dano, bastando a exposição da sociedade aos riscos; d) servir como garantia à conservação dos bens ambientais juridicamente protegidos.

Nessa versão, a responsabilidade civil não se ocupa apenas do passado, regressivamente, mas volta-se ao futuro, investida de novas missões. É perceptível, nesta proposta, que a responsabilidade civil deve partir de uma análise funcional do Direito, em que a questão estrutural da responsabilidade, a investigação e delimitação de seus pressupostos cedem espaço ao questionamento referente às funções assumidas pela mesma na contemporaneidade. Essa compreensão será explorada com maior profundidade a seguir. 


\section{CAPÍTULO 2. ENFOQUE FUNCIONALISTA COMO ESTRATÉGIA PROSPECTIVA DA RESPONSABILIDADE CIVIL}

\subsection{CAUSAS SUBJACENTES À TEORIA FUNCIONALISTA DO DIREITO}

A chegada do Iluminismo com a inerente racionalidade propiciou novas perspectivas em diversas ciências, e especialmente ao Direito, como sistema de regulação de comportamentos sociais. Não se trata mais de um direito repressivo, ${ }^{112}$ baseado na autoridade exclusiva do chefe de Estado e que se consolida frente aos padrões de subordinação social, ${ }^{113}$ onde o benefício da dúvida é interpretado a favor do sistema e a conveniência administrativa tem elevado peso. Ao contrário, com o Liberalismo inicia-se o um período em que se destaca a autonomia do Direito.

A mutação do direito repressivo em direito autônomo pelo observatório político teve causa brusca, conforme o lastro histórico aponta, ${ }^{114}$ no levante armado que dissipou vidas durante a Revolução Francesa e correlata "Queda da Bastilha" de 1789, consagrando a conhecida "Fête de la Fédération". Entretanto, no campo da ciência jurídica há mesmo o reconhecimento de certa evolução do Direito. ${ }^{115}$

112. A expressão é de NONET, Philippe; SELZNICK Philip.Direito e sociedade: a transição ao sistema jurídico responsivo. Trad. Vera Ribeiro. Rio de Janeiro: Revan, 2010, p.75.

113. DURKHEIM, Émile. Leçons de sociologie - Pshysique des moeurs et du Droit. Paris: PUF, 1950, p.37 et seq. Interessante abordagem sobre a solidariedade, pois no pensamento do sociólogo francês, nos Estados com menor distribuição de recursos e maior concentração de poder, há destaque para a solidariedade mecânica, apta a fortalecer o Estado pela penalização de condutas; enquanto nos Estados com maior distribuição de recursos e menor concentração de poder ganha volume a solidariedade orgânica, onde o tráfego civil percorre com maior desenvoltura na sociedade.

114. HATTENHAUER, Hans. Los fundamentos histórico-ideológicos del Derecho Aleman: entre la jerarquia y la democracia. Trad. Miguel Izquierdo Macias-Picavea. Madrid: Editorial Revista de Derecho Privado, 1981, p.17: “Cada época histórica há de escribir sua propia Historia del Derecho, y asimismo há de redistribuir el material histórico-jurídico existente (...). Tradicionalmente señalamos como fecha del comienzo de la más reciente Historia del Derecho el año 1789, inicio de la Revolución francesa. Ningún motivo existe para discrepar de ello. También para la Historia del Derecho vale el aserto de que las conmociones de la Revolución de 1789 llevaron a un cambio fundamental de las circunstancias jurídicas no solo em Francia, sino en todo el continente y especialmente en Alemania".

115. DEL VECCHIO, Giorgio. Evoluzione ed involuzione del Diritto. $3^{\text {a }}$ ed. Roma: Studium Urbis, 1945 , p.11. 
Em consequência, o racionalismo filosófico decorrente da Revolução Francesa, pontuado na liberdade, igualdade e fraternidade, serviu de base para a instituição de duas construções jurídicas essenciais na ruptura com o ancien régime: a Constituição de 1791 e o Código Civil de $1804 .{ }^{116}$ Vale dizer, o rompimento foi decididamente político, no entanto, sem total desprezo ao manancial de costumes jurídicos anteriores ainda úteis, considerando o elemento cultural que sempre subjaz ao Direito civil. ${ }^{117}$

Ainda que no mesmo período fosse possível verificar ampla modificação das fontes, especialmente pela providência de pioneira codificação do Estado gendarme ao revés de meras compilações, certas figuras do Direito permaneceram intocadas. Como exemplo, no tema que se desenvolve inerente à responsabilidade civil, as estruturas expostas quanto ao dever de indenizar próprias do Direito romano pela Lex Aquilia ${ }^{118}$ ou mesmo o princípio neminem laedere, ${ }^{119}$ aproveitados, dentro das possibilidades

116. KAUFMANN, Arthur. Filosofia do direito, teoria do direito, dogmática jurídica. In: Arthur Kaufmann e Winfried Hassemer. Introdução à filosofia do direito e à teoria do direito contemporâneas. Trad. Marcos Keel. Lisboa: Fundação Calouste Gulbekian, 2002, p.92: “Também já era chegado o tempo da maturidade para se transformar o direito natural do iluminismo em codificações. $\mathrm{O}$ sistema global delineado por Christian Wolff (a ideia de todo o conhecimento é característica do racionalismo) aplanou os caminhos para os códigos jusnaturalistas dos séculos XVIII e XIX. Aqui só podem ser mencionados os quatro mais significativos: Codex Maximilianeus Bavaricus (1756), Código da Prússia (1794), Code civil (Code Napoleon, 1804), Código civil austríaco [ABGB] (1811)”.

117. MENEZES CORDEIRO, António. Tratado de Direito Civil Português. Parte geral. Tomo I. $3^{\mathrm{a}}$ ed. Coimbra: Almedina, 2007, p.75, explica: "A adaptação dos institutos a novas realidades tem-se prestado a equívocos que, por desvirtuarem a essência das codificações civis, cabe esclarecer. O Código Napoleão é, com frequência, assimilado a um diploma cheio de intenções perante a revolução liberal e a burguesia industrial que se anunciavam. Há muito se proclama o infundado desta orientação: a primeira codificação traduz apenas o ponto de chegada de uma evolução complexa, iniciada com os comentaristas, renovada pelo humanismo e pela primeira sistemática e inflectida pelo jusracionalismo. Entre a doutrina pré-revolucionária e o Código não há quebras ou, sequer, evoluções significativas, pelo contrário: o Código Napoleão pôs cobro a múltiplas inovações introduzidas durante o período revolucionário, adoptando soluções anteriores. A adaptação dos institutos a novas realidades, quando da efectivação de uma nova codificação civil, tem, pois, outro alcance: trata-se de generalizar segmentos já aproveitados e comprovados sectorialmente, de consagrar inovações preconizadas pela doutrina, de limar arestas em esquemas há muito conhecidos ou de irradicar fórmulas consideradas, de modo pacífico, como inúteis".

118. FRANÇA, R. Limongi. As raízes da responsabilidade aquiliana. In: NERY Jr., Nelson; NERY, Rosa Maria Andrade (Org.). Doutrinas Essenciais Responsabilidade Civil. Volume I. Teoria Geral. São Paulo: Editora Revista dos Tribunais, 2010, p.267.

119. ALPA, Guido. La responsabilità civile. Principi. Milano: Utet Giuridica, 2010, p.54. Refere-se ao mencionado princípio base da cláusula geral prevista no art. 2043 do Codice Civile que indica tanto regra de comportamento como preceito que comporta sanção. Nesse ponto, indica dois fundamentos propositivos da responsabilidade civil atual: 'la lesione di interessi apprezzabili' e 'la individuazione dei criteri di imputazione'. 
metodológicas, ${ }^{120}$ pelo Código Civil francês ${ }^{121}$ e posteriores legislações.

Esse direito autônomo com base no Liberalismo corresponde a diversos movimentos filosóficos e científicos em espaços temporais diferenciados, que merecem destaque: a Escola Histórica, vazada no raciocínio de que o direito é emanação do espírito do povo, cabendo ao legislador limitar-se em consagrar costumes experimentados comunitariamente, ${ }^{122}$ o positivismo jurídico, fortalecido no pensamento crítico kantiano de que o direito natural é impotente quando não lastreado pelo empírico, pois desvalido de conteúdo inequívoco igual para todos os componentes da sociedade (complexidade); ${ }^{123} \mathrm{o}$ fundamento da legitimidade, ao lado da legalidade, através do ideário hegeliano de que o Estado é a união geral das pessoas com liberdade e bem-estar e, portanto, a vontade do Estado é a legítima; ${ }^{124} \mathrm{e}$, e em momento posterior, o neokantismo.

Entre os neokantistas, o pensamento de Hans Kelsen ${ }^{125}$ tem grande importância, pelos contornos fornecidos à ciência do Direito, seguido de Norberto

120. LALOU, Henri. Traité pratique de la responsabilité civile. Quatrième édition. Paris: Dalloz, 1949, p.4, menciona, como de resto, certas diferenças: "A Rome, les délits et les quasi-délits étaient nettement distingués, tandis que dans la législation française, il n'y a ni raison théorique ni intérêt pratique à faire cette distinction".

121. Art. 1.382. Tout fait quelconque de l'homme, qui cause à autri un dommage, oblige celui par la faute duquel il est arrivé, à le réparer.

122. SAVIGNY, Friedrich Carl Von, De la vocación de nuestro siglo para la legislación y para la ciencia del derecho. Trad. Adolfo Posada. Granada: Editorial Comares, 2008, p.39: "los juristas necesitan, ciertamente, una doble capacidad: capacidad histórica para recoger con acierto todo cuanto hay de característico en cada época y en cada forma del derecho, y capacidad, que llamaremos sistemática, para considerar toda ideia y todo principio en íntima relación y acción recíproca con el conjunto, que es tanto como decir, em sua posición natural y verdadera".

123. WOLF, Erik. El problema del derecho natural. Trad. Manuel Entenza. Barcelona: Ariel, 1961, p.29: "La multivocidad de la cuestión, su variedad de aspectos corresponden a otras tantas posibilidades de plantear el problema relativo a lo que generalmente se considera contradicción del iusnaturalismo: el positivismo, ya sea entendiéndolo históricamente, como contricante en lucha, ya sea racionalmente concebido como concepto del que el iusnaturalismo se distingue".

124. HEGEL, George Wilhelm Friedrich, A razão na história: uma introdução geral à filosofia da história. Trad. Beatriz Sidou. $2^{\circ}$ ed. São Paulo: Centauro, 2001, p.90: “O Estado é a realização da liberdade, do objetivo final absoluto, e existe por si mesmo. Todo o valor que tem o homem, toda a sua realidade espiritual, ele só a tem através do Estado. Sua realidade espiritual é a presença consciente para ele de sua própria essência, a presença da razão, de seu objetivo, a realidade imediata presente em si e para si. Só assim ele tem plena consciência, assim ele compartilha da moral, da vida legal e moral do Estado, pois a verdade é a união da vontade universal com a vontade particular. $\mathrm{O}$ universal no Estado está em suas leis, suas disposições racionais e universais. O Estado é a ideia divina como ela existe sobre a terra".

125. Teoria pura do direito. Trad. João Batista Machado. $4^{\text {a }}$ ed. São Paulo: Martins Fontes, 1994. 
Bobbio $^{126}$ quando proporciona à ciência jurídica, sem abandono ao positivismo, um diálogo de interdisciplinaridade, particularmente com a sociologia. Esta última designação, portanto, exige maior reflexão, pois neste domínio é possível realizar a análise entre estrutura e função como elementos fundantes do sistema jurídico, consoante elaboração a seguir.

\subsection{DO ESTRUTURALISMO AO FUNCIONALISMO: GIRO METODOLÓGICO PARA A AMBIENTAÇÃO DA RESPONSABILIDADE CIVIL PREVENTIVA}

Em Hans Kelsen, ${ }^{127}$ é possível encontrar uma concepção de direito autossuficiente e autônomo, indiferente à política, à sociologia ou à economia. Esta pureza do direito caminha centrada na norma jurídica, na verificabilidade estática e na verificabilidade dinâmica, reduzindo o Direito à concepção de validade.

O primeiro estágio dessa teoria pura evidencia o âmbito da norma estática com imersão nos seguintes aspectos: coerção - não mais como um meio para fazer valer o ordenamento, senão como objeto ou regulação do uso da força; ${ }^{128}$ ilícito - mala proibitha e, nesse desiderato, condição essencial da norma para aplicação da sanção; ${ }^{129}$ dever jurídico - relação entre a norma e o indivíduo, de consequência que sua violação é ensejadora do ilícito; ${ }^{130}$ direito subjetivo - com existência reflexa ao dever jurídico e nessa situação pressupõe um direito objetivo correspondente; ${ }^{131}$ responsabilidade - obrigação

126. Teoria generale del diritto. Torino: G. Giappichelli Editore, 1993.

127. Teoria pura do direito. Trad. João Batista Machado. $4^{\mathrm{a}}$ ed. São Paulo: Martins Fontes, 1994.

128. BOBBIO, Norberto. O positivismo jurídico: lições de filosofia do direito. Trad. Márcio Pugliesi, Edson Bini, Carlos E. Rodrigues. São Paulo: Ícone, 1995, p.155.

129. KELSEN, Hans. op.cit., p.124: "a condição ou o pressuposto de um ato de coerção estatuído pela mesma ordem jurídica, representa o fato designado como ilícito ou delito".

130. KELSEN, Hans. op.cit., p.cit., p.130: “juridicamente obrigado está o indivíduo que, através da sua conduta, pode cometer o ilícito, isto é, o delito, e assim, pode provocar a sanção, a consequência do ilícito".

131. KELSEN, Hans. op.cit., p.143: "Se se designa a relação do indivíduo, em face do qual uma determinada conduta é devida, com o indivíduo obrigado a essa conduta como 'direito', este direito é apenas um reflexo daquele dever". 
imposta pela conduta desenvolvida e que originou uma sanção. ${ }^{132}$

$\mathrm{Na}$ sequência decorre o dinamismo da teoria pura, porque o positivismo kelseniano neste ponto fixa-se na perspectiva do entrelaçamento das normas jurídicas, sendo que uma retira de outra imediatamente superior o fundamento de validade, sem se descurar de um mínimo de eficácia. ${ }^{133}$

Outra característica indissociável à teoria pura centra-se no estabelecimento de pontos de partidas inquestionáveis, os chamados dogmas, cujas feições mais evidentes são: a adesão ao positivismo; a irrelevância de investigar a qualidade da norma, senão apenas a inerente validade; o mito da completude do sistema jurídico, porque o legislador a tudo prevê e o ordenamento a tudo provê; a imperatividade e coerência da ordem jurídica; a proibição de denegação jurisdicional (sentença non liquet). ${ }^{134}$

Sob o aspecto metodológico, o Direito, em termos científicos, ficou centrado em estratégia caracterizada pela estrutura. Modelos estruturais e até mesmo classificatórios são objetos, há séculos, da ciência do Direito. Exemplifica-se a partir da própria norma jurídica, que junto ao antecedente fático, guarda a estatuição, ou seja, o consequente jurídico. Ademais, a estrutura informa a existência de situações ou relações jurídicas através de institutos, que até mesmo ultrapassam a summa divisio direito público e direito privado: ato e negócio jurídico; classificação das obrigações e contratos; conceito analítico de crime (teorias bipartite, tripartite ou quatripartida); taxonomia de ato administrativo; divisão entre Estado, poder e direitos e garantias fundamentais na Constituição. No domínio dogmático, a doutrina brasileira evidencia o estruturalismo, por exemplo, através do positivismo científico de Pontes de Miranda, ${ }^{135}$ que trouxe à ciência

132. KELSEN, Hans. op.cit., p.133. Ao distinguir dever jurídico de responsabilidade, informa: "um indivíduo é juridicamente obrigado a uma determinada conduta quando uma oposta conduta sua é tornada pressuposta de um ato coercitivo (como sanção)".

133. LOSANO, Mario G. Sistema e estrutura no direito. Volume: 2. O século XX. Trad. Luca Lamberti. São Paulo: Martins Fontes, 2010, p.97: "no vértice da pirâmide normativa kelseniana, a norma fundamental transmite às normas inferiores a validade fundada no dever ser (sollen). Em Kelsen a definição de validade é ambígua. No sentido mais próximo da teoria pura do direito, a validade é a 'específica existência da norma', ou seja, seu fazer parte do ordenamento, sua inclusão na pirâmide normativa: isso se verifica quando uma norma é produzida conforme as regras prescritas pelas normas de nível superior".

134. NINO, Carlos Santiago. Consideraciones sobre dogmática jurídica. México: Unam, 1974, p.11.

135. PONTES DE MIRANDA, Francisco Cavalcante. Tratado de direito privado. t. IV. $3^{\circ}$ ed. Rio de Janeiro: Bosch, 1972. 
jurídica a teoria do fato jurídico, e a divisão do negócio jurídico em três planos, destacando os componentes de existência, validade e eficácia.

Ocorre que, após a segunda guerra mundial, a Declaração dos Direitos do Homem de 1948, entre outras, ocasionou a mudança de critérios hermenêuticos e metodológicos nos Estados pós-liberais, abrindo-se espaço para novas fontes, dentre elas o humanismo ${ }^{136}$ e o resgate da valoração da justiça. ${ }^{137}$ Não se tratava mais de um sistema para dizer, senão de um sistema para fazer, ${ }^{138}$ com realce aos aspectos promocional e prospectivo.

A funcionalização de direitos teve seu marco histórico na Constituição de Weimar, de 1919, ao prescrever que a propriedade "obriga", impondo ao titular de um direito outrora tido como absoluto e sagrado na visão liberal e individualista a realização de condutas positivas e negativas em garantia do bem-estar da sociedade.

Em consequência, o estruturalismo, mesmo essencial no arcabouço 'cultural' da teoria do Direito, passou por sérios questionamentos, particularmente em virtude da ausência de multidisciplinaridade, apta a permitir a comunicação entre o Direito e a sociedade, típica do diálogo entre a sociologia e a efetividade. Em outras palavras, o estruturalismo estava impregnado de neutralidade, ${ }^{139}$ indolente com a humanidade do pósguerra, porque preso ao liberalismo avesso ao sistema de recompensas.

A esse modelo Norberto Bobbio opôs séria crítica. ${ }^{140}$ Mesmo sem deixar de

136. BRITTO, Carlos Ayres. O humanismo como categoria constitucional. Belo Horizonte: Fórum, 2007, p.22. Vale transcrever a linha de pensamento: “É o que se pode designar por constitucionalismo cumulativo. Um constitucionalismo crescentemente superavitário, como se dá com a ciência e a cultura, a ponto de autorizar a ilação de que, graças a ele, o Estado de Direito termina por desembocar num Estado de Direitos. O que não significa uma generalizada situação de afrouxamento dos deveres e responsabilidades de cada indivíduo para com o próprio Estado e a sociedade civil. As duas coisas bem podem conviver na mais perfeita harmonia".

137. RADBRUCH, Gustav. Arbitrariedad legal y derecho supralegal. Buenos Aires: Abeledo-Perrot, 1962, p.35. Na passagem para o mundo dos valores, Radbruch no final da vida brinda o direito: "El positivismo há desarmado a los juristas alemanes frente a leys de contenido arbitrário y delictivo. El positivismo, además, no está em condiciones de fundar com sus propias fuerzas la validez de las leys".

138. A expressão é de LOSANO, Mario G. Sistema e estrutura no direito. Volume: 2. O século XX. Trad. Luca Lamberti. São Paulo: Martins Fontes, 2010, p.133.

139. PUGLIATTI, S. La prorietà nel nuovo diritto. Milano: Giuffrè, 1954, p.300: "un tipo strutturale è strumento per sé neutro, utilizzabile per il conseguimento di diversi fini”".

140. BOBBIO, Norberto. Da estrutura à função: novos estudos de teoria do direito. Trad. Daniela Beccaccia Versiani. Barueri: Manole, 2007, p.54. 
lado a importância da estrutura no positivismo, demonstrou que o plano da efetividade (efeito+atividade), através de funções premiais, tem papel relevante na transformação da sociedade.

Nesse passo, importante realizar, em breves linhas, a análise de sua teoria, como justificativa para a transformação metodológica de que decorre o estudo das funções do Direito.

Em primeiro lugar, Bobbio estabeleceu que a diferença entre comandos e proibições não é a mesma que decorre na assimetria entre sanções positivas e negativas. Neste caso pode haver amplas situações de mixagem entre os quatro elementos (comandos reforçados por prêmios; comandos reforçados por castigos; proibições reforçadas por prêmios; proibições reforçadas por castigos). ${ }^{141}$

Num segundo plano, Bobbio, dentro das sanções positivas, apresenta o dualismo entre prêmio e incentivo, destacando que o último é tocado como medida para facilitar o exercício de determinada atividade econômica, enquanto o primeiro seria a recompensa a quem se desincumbiu de realizar a atividade exigida pelo programa jurídico.

Por derradeiro, em um terceiro plano, propõe a dicotomia entre normas de conduta e normas de organização, bem como normas sancionatórias e normas técnicas. Enquanto as normas de conduta pacificam a convivência humana, as normas de organização estabelecem nichos de cooperação entre os indivíduos. De outro lado, as normas técnicas, que diferem daquelas simplesmente sancionatórias, podem ser divididas em normas que estabeleçam determinando meio para atingimento de um fim (normas instrumentais) ou normas que imponham determinando fim a ser alcançado (normas de direção). ${ }^{142}$

A teoria funcionalista de Norberto Bobbio, sem dúvida, alcançou aplicação normativa no Direito brasileiro. É possível observar, por exemplo, que de forma mais incisiva após a Constituição Federal de 1988, a emergência de inúmeros microssistemas dedicados a setores especialmente frágeis, e que necessitavam de certa 'parcialidade' normativa para fortalecimento no ambiente social, uma vez que o próprio texto

$$
\begin{aligned}
& \text { 141. Op.cit., p.6. } \\
& \text { 142. Op.cit., p.44. }
\end{aligned}
$$


constitucional reconhece situações de desigualdade e especial vulnerabilidade, como a criança e adolescente, idosos, consumidores, portadores de necessidades especiais e futuras gerações. $^{143}$

Igualmente, referida teoria propiciou a abertura para novas técnicas legislativas, dentre elas a adoção das cláusulas gerais, ${ }^{144}$ ao lado da técnica regulamentar, que demonstra a abertura sistêmica para a solução do caso concreto, aptas a proporcionar mobilidade e servir de instrumento para a aplicação de princípios.

Portanto, o cotejo entre o estruturalismo e o funcionalismo é capaz de evidenciar algumas dualidades, aqui sintetizadas: para a estrutura o Direito é, enquanto para o funcionalismo o direito serve; para a estrutura o direito é norma, enquanto para o funcionalismo o direito é sistema; para a estrutura a estratégia é retrospectiva (visão para o passado), enquanto para o funcionalismo a estratégia é prospectiva (visão para o futuro); para a estrutura o controle social é repressivo (a posteriori), enquanto para o funcionalismo o controle social é diretivo (a priori); para a estrutura o mote é a estabilidade social' pela conformação do Direito, enquanto para o funcionalismo o objetivo é a transformação social pelo incentivo do Direito.

Podem-se ilustrar ainda diversas outras abordagens científicas sobre estrutura e função, verificadas especialmente pela sociologia do Direito.

143. MARQUES, Cláudia Lima; MIRAGEM, Bruno. O novo direito privado e a proteção dos vulneráveis. São Paulo: Editora Revista dos Tribunais, 2012, p.129: "É assim que o valor do direito (dignidade da pessoa humana) como um todo, domina o sistema de valores (Wertsystem) constitucional, a orientar (inclusive na sistematização-valorativa) o novo direito privado brasileiro. Daí porque, nesta obra, o fator igualdade será examinado com precedência em relação à liberdade, fator típico do direito privado. E esta, de sua vez, só terá efetividade uma vez que se reconheçam situações estruturais de desigualdade e se protejam os vulneráveis. Observe-se que este é o sentido dos direitos fundamentais reconhecidos à criança e ao adolescente (art. 227 da CF/1988), aos idosos (art. 226, $\mathrm{CF} / 1988$ ), aos consumidores (art. 5 ${ }^{\circ}, \mathrm{XXXII}$, da CF/1988), e à proteção aos portadores de necessidades especiais (art. $7^{\circ}, \mathrm{XXXI}, 23, \mathrm{XIV}$, e 227, II, da CF/1988) e às futuras gerações (art. 225, in fine).

144. Já tivemos a oportunidade de nos pronunciar em outro trabalho que: “[...] esta nova técnica normativa traz modificações profundas na aplicação do direito, exatamente porque confere ao magistrado uma maior interferência na solução dos conflitos, mantendo, contudo, o comprometimento deste com aspectos de valoração buscados no meio social, como a dignidade da pessoa humana, socialidade, eticidade, entre outros, abrindo uma maior possibilidade de alcance da justiça social, aspecto este absolutamente inovador na codificação civil brasileira. Essa abertura do sistema jurídico propiciará o seu contínuo aperfeiçoamento, através do trabalho hermenêutico dos aplicadores do direito que, aptos a reconhecer a modificabilidade dos seus valores fundamentais, poderão adaptar o ordenamento à dinâmica social". FERREIRA, Keila Pacheco. Abuso do direito nas relações obrigacionais. Belo Horizonte: Del Rey, 2007, p.129. 
Niklas Luhmann ${ }^{145}$ credita à sociedade viés de pura comunicação funcional, o que permite a autoconstrução do Direito como ciência autopoiética, porque aberta cognitivamente para o ambiente (sociedade) e fechada operativamente. Através de seus códigos binários (lícito/ilícito; direito/não direito) o direito tem como função a redução das complexidades. A importância de sua teoria para o tema da responsabilidade civil radica na normatização de condutas, após os critérios de hipercomplexidade, contingência e seleção, posto que o direito positivo retiraria a insegurança nas inúmeras e complexas relações sociais e daí surgiriam as inúmeras normas secundárias, especialmente de agências reguladoras, para a proteção do meio ambiente, consumidor, entre outros.

Pertinente, por fim, abordar o pensamento de Antônio Castanheira Neves, que em análise profunda trata do relevo normativo-metodológico do resultado da decisão e se ocupa dos efeitos do juízo decisório sobre a sociedade. Nessa visão, a decisão jurídica deve estar, além de normativamente fundamentada e materialmente justa, socialmente justificada (oportuna e aceitável), auxiliando no controle da razoabilidade, por exemplo, de sentenças e pedidos de indenização milionários e despropositados. ${ }^{146}$

Ante o exposto, considerando a modificação histórica dos modelos de responsabilidade civil e nexos de imputação - da culpa como fonte de indenizabilidade ao risco como fonte de evitabilidade, é possível verificar na metodologia funcionalista um ambiente propício ao pleno desenvolvimento de uma responsabilidade civil em que se avulta uma função preventiva, antecipatória da ocorrência de danos graves e complexos. ${ }^{147}$ Acompanha esta conclusão Patrícia Faga Iglecias Lemos, ao observar que:

[...] todas as considerações até aqui apresentadas, desde a flexibilização do nexo causal e das novas funções da responsabilidade civil até a cogitação do binômio responsabilidade sem dano/dano sem responsabilidade, decorrem de uma profunda alteração no modo de

145. LUHMANN, Niklas. Legitimação pelo procedimento. Brasília. UNB, 1980, p.25. "Para toda a gente o mundo é excessivamente complexo, cheio de possibilidades imprevisíveis e, como tal, desconcertante. Cada indivíduo precisa, portanto, duma orientação significativa e duma direção de vida para poder adotar obras de seleção de outros, quer dizer, que possa tratar o sentido que os outros escolheram, como tal e não como se fosse diferente. Essa transmissão pode ser realizada por meio de mecanismos sociais diversificados, que nas sociedades mais primitivas não se diferenciam, atuam em conjunto e trazem, portanto, uma reconstrução da realidade de complexidade diminuta".

146. CASTANHEIRA NEVES, António. Metodologia jurídica: problemas fundamentais. Coimbra: Coimbra Editora, 1993, p.197.

147. BOUTONNET, Mathilde. Le principe de précaution en droit de la responsabilité civile. Paris: L.G.D.J., 2005, p.190. 
pensar esse ramo do direito. É, em última análise, a consagração de uma nova abordagem, de cunho funcionalista, desapegada do formalismo que historicamente acompanhou o estudo do direito. ${ }^{148}$

Em outras palavras, com apoio em Nonet e Selznick, pode-se compreender que o estabelecimento de funções aos institutos jurídicos contribui para a elaboração de missões legais que determinam a investigação das consequências concretas dos fatos e das normas na realidade. Nesse viés, o Direito é "orientado para resultados e se diferencia nitidamente da imagem clássica da justiça cega a consequências". ${ }^{49}$

Assim, no momento em que a responsabilidade civil assume, a par da função reparatória, também uma função preventiva prospectiva, a racionalidade da argumentação jurídica nesse campo do Direito também sofre modificações, e induz à reavaliação do instituto à luz de suas consequências para os valores envolvidos, decorrentes da nova ética de proteção, segurança e antecipação emergentes na sociedade, consoante já exposto no capítulo anterior.

Nessa linha de pensamento, passamos, a seguir, à exposição das múltiplas funções assumidas pela responsabilidade civil na contemporaneidade.

\subsection{MULTIFUNCIONALIDADE DA RESPONSABILIDADE CIVIL NA PÓS- MODERNIDADE}

O desenvolvimento do tópico anterior revela que a tendência atual no estudo da responsabilidade civil acabou por desnudar quadro metodológico em giro diverso, essencialmente no plano da efetividade, descortinando o prestígio de funções as quais mesmo anteriormente existentes, não eram aprofundadas pela teoria geral do Direito.

Afastando-se da concepção estrutural do Direito, focada na abordagem

148. Resíduos sólidos e responsabilidade civil pós-consumo. São Paulo: Editora Revista dos Tribunais, 2011, p.208.

149. NONET, Philippe; SELZNICK Philip.Direito e sociedade: a transição ao sistema jurídico responsivo. Trad. Vera Ribeiro. Rio de Janeiro: Revan, 2010, p.134. 
técnico-jurídica e consequente análise de seus elementos estruturais, a funcionalização da responsabilidade civil, como dos demais institutos de Direito civil, como a propriedade, contrato e empresa, permite uma melhor compreensão do fenômeno jurídico através da aproximação interdisciplinar do mesmo com as ciências sociais, despertando o operador do direito para uma postura crítica com relação à eficácia das normas e institutos jurídicos de acordo com a realidade que o circunda. ${ }^{150}$ Disso resulta o interesse da sociedade em promover a organização e direção sociais através dos mecanismos jurídicos, acrescentando à tradicional função repressiva atribuída ao Direito, também outras funções, de natureza promocional e inovadora. ${ }^{151}$

A princípio, ainda que singelamente, valem os exemplos de estudos contemporâneos que tornam evidente a adoção dessa nova lógica civilística no âmbito da responsabilidade civil, em perspectiva nacional e estrangeira.

No Direito francês, cultura jurídica que muito influencia a presente pesquisa, pode-se verificar Suzanne Carval referindo-se à 'la fonction des dommages et interets punitfs' no sentido de que a utilização da pena privada é caracterizada por forte coerência. ${ }^{152}$ Igualmente, esse setor do Direito comparado informa que dentre as funções da culpa se adere aquela de prevenção, ${ }^{153}$ ou que há necessidade de operacionalização das funções da responsabilidade civil, com menção às funções de reparação, prevenção, repressão, todas acompanhadas de um modelo de agir social. ${ }^{154}$

Assemelha-se com isso o manejo das funções de prevenção ou de cessação

150. Anota NERY, Rosa Maria de Andrade. Introdução ao pensamento jurídico e à teoria geral do Direito Privado. São Paulo: Editora Revista dos Tribunais, 2008, p.246: "É a ideia da fixação de parâmetros axiológicos para a formação do princípio e da consequente disposição psicológica para torná-la funcionalmente operante. A funcionalidade do direito tem ligação com isso. Com a utilização do conhecimento em favor de uma finalidade. O conhecimento tem como função interna a nossa vida, vida como realidade radical".

151. AMARAL, Francisco. Direito Civil: introdução. 3. ed. Rio de Janeiro: Renovar, 2000, p.355.

152. CARVAL, Suzanne. La responsabilité civile dans sa fonction de peine privée. Paris: L.G.D.J, 1995, p.52.

153. TOURNEAU, Philippe le. La responsabilité civile. Paris: PUF, 2003, p.12., ensina que: "Liée au rôle normatif, la première fonction de la responsabilité subjective est de prévenir les dommages plus que les réparer".

154. SINTEZ, Cyril. La sanction préventive em droit de la responsabilité civile: contribuition à la théorie de l'interprétation et de la mise en effet des normes. Paris: Dalloz, 2010, p.331/353. 
do ilícito, no Direito francês, reforçando a efetividade da responsabilidade civil, ${ }^{155}$ com plena adequação temática ao tema desenvolvido nesta pesquisa. Ademais, encontra-se certa referência à promoção da responsabilidade civil, com antecipação do dano, pelos defeitos de prevenção e de precaução. ${ }^{156}$

O pensamento jurídico alemão, dentre tantos pioneirismos revelados no direito obrigacional do sistema civil law, consagrou na década de setenta o princípio da precaução (Vorsorgeprinzip) ${ }^{157}$ com relevante aporte na responsabilidade civil. Contudo, do mesmo modo evoluiu na fixação da função de satisfação como essência nas indenizações equitativas para danos não patrimoniais, conforme $\S 847$ do BGB. ${ }^{158}$

No Direito italiano Guido Alpa, adepto ao método de interpretação conhecido como análise econômica do direito, disserta sobre as funções tradicionais e subsidiárias da responsabilidade civil como fundamentos deste instituto, elencando: ressarcimento; repristinação ao status quo ante; reafirmação do poder sancionatório do Estado; preventiva (deterrence); distribuição de perdas; alocação de custos. ${ }^{159}$

155. VINEY, Geneviève; JOURDAIN, Patrice. Les effets de la responsabilité. $3^{\mathrm{a}}$ edition. Paris: L.G.D.J, 2011, p.40.

156. TAPINOS, Daphné. Prévention, précaution et responsabilité civile: risque avéré, risque suspecté et transformation du paradigme de la responsabilité civile. Paris: L'Harmattan, 2008, p.525.

157. STANZIONE, Maria Gabriella. Principio di precauzione responsabilità civile e diritto alla salute nelle esperinze francese e italiana. Salermo: Brunolibri, 2010, p.20. Com a seguinte indicação: "Le origini del principio di precauzione si fanno unanimemente risalire all'ordinamento tedesco degli anni settanta allorché il Vorsorgeprinzip è dottato al fine di indurre i soggetti economici a prendere provvedimenti control l'inquinamento in asseza di certezze scientifique riguardanti $\mathrm{i}$ rischi per l'ambiente".

158. KERN, Bernd-Rüdiger. A função de satisfação na indenização do dano pessoal: um elemento penal para a satisfação do dano? In: Revista de direito do consumidor. v. 33. São Paulo: Revista dos Tribunais, 2000, p.10. Na consideração de que a função compensatória é meramente simbólica, já que o dano imaterial não pode ser calculado em valor monetário, a função satisfatória permitiria melhor indenizabilidade. Diz o autor: "Por tais motivos, a função de satisfação é adicionada à compensação, complementa-a em diferentes medidas. Ela expressa uma determinada relação pessoal que o fato danoso suscita entre o ofensor e o ofendido, a qual, por sua natureza, exige que na determinação do montante devido sejam levadas em consideração todas as circunstâncias do caso".

159. ALPA, Guido. La responsabilidade civile. Parte generale. Torino: Utet Giuridica, 2010, p.160. Informa que: "La responsabilità civile assolve (in ogni tempo e in ogni luogo) quattro funzioni fondamentali. Si indicano cosi: a) la funzione di reagire all'atto illecito, allo scopo di risarcire i soggetti ai quali il danno è stato recato; b) la funzione di ripristinare lo status quo ante nel quale il danneggiato versava prima di subire il pregiudizio; c) la funzione di riaffermare il potere sanzionatorio (o punitivo) dello stato; d) la funzione di 'deterrente' per chiunque intenda compire atti o a svolgere attività da cui possono derivare effetti pregiudizievoli per i terzi. A queste quattro funzioni si affiancano poi alcune funzioni sussidiarie, che più propriamente attengono agli effetti economici della responsabilità civile: e) la distribuzione delle perdite, da un lato, f) l'allocazione dei costi, dall'altro". 
No que respeita a responsabilidade objetiva, aponta Pietro Trimarchi sobre a função econômica que justifica a cautela individual e social frente às atividades da empresa, o que importa em verdadeiro controle das situações de risco. ${ }^{160}$ Ainda Paolo Gallo observa que a responsabilidade civil tem funções fragmentárias que podem tanto levar ao ressarcimento quanto à reprimenda. ${ }^{161}$

Cabe ainda realçar da doutrina italiana a chamada função de garantia proveniente do princípio da solidariedade, com base num sistema de social security, que abandona a justiça retributiva a favor da forma distributiva e prestigia o seguro social ao invés de um esquema típico de ressarcimento privado. ${ }^{162}$

Ideia de funções atinentes à responsabilidade civil existe, igualmente, na Espanha, onde além da indicação da reparabilidade, há finalidade preventiva com traço econômico. $^{163}$

160. TRIMARCHI, Pietro. Rischio e responsabilità oggettiva. Milano: Giuffrè, 1961, p.36.

161. GALLO, Paolo. Introduzione alla responsabilità civile: articole 2043/2059 C.C. Torino: G. Giappichelli Editore, 2000, p.5. Menciona: "Anche sotto il profilo della funzione dei rimedi previsti dal codice è possibile notare come mentre in alcuni casi prevale la funzione risarcitoria (art. 2043 c.c.), in altri casi prevale nettamente la funzione sanzionatoria e satisfattoria (art. 2.059 c.c.). In doctrine si è parlato di frammentazione della responsabilità civile. In alcuni casi si è in altre parole in presenza di un danno da risarcire, in altri di un comportamento da reprimere e disincentivare. In questo condizioni gli stessi presupposti di aplicazione dei vari rimedi possono mutare".

162. FERRARI, Vicenzo. La funzione di garantia nella responsabilità civile. Napoli: Edizioni Scientifique Italiane, 2005, p.106. Apresenta inclusive as possibilidades classificatórias da função de garantia: "Sicché la funzione 'reintegratice' può essere ridefinita come funzione di garanzia della conservazione del patrimoni dalle aggressioni altrui; la funzione 'solidaristica', come garanzia di preservazione della sfera della personalità o anche garanzia di conservare la qualità della vita mediante l'attribuzione di utilità sostitutive del bene irrimediabilmente leso; la funzione 'preventiva' ed analogamente quella 'sanzionatoria' come garanzia di ottenere la tutela in anticipo rispetto all'evento dannoso attraverso la dissuasiva minaccia di assunzione dell'obligazione risarcitoria; la funzione 'distributiva', come garanzia del risarcimento attraverso un'allocazione efficiente del rischio. La funzione di garantia costituisce, pertanto, l'alveo comune nel quale il sistema di responsabilità civile può vedere incanalata ogni concezione, dalla più tradizionale alla maggiormente evolutiva, realizzando quella prospettiva unitária di recente autorevolmente preconizzata in una interpretazione assilogica che consenta di calibrare la "funzione riparatrice del danno ingiusto ovvero del símplice danno a prescindere dalla ingiustizia, secondo i correttivi della proporzionalità e della ragionevolezza".

163. DÍEZ-PICAZO, Luís. Fundamentos del derecho civil patrimonial: la responsabilidad civil extracontractual. v. 5. Pamplona: Civitas, 2011, p.27. Alude: “[...] si los costes de prevéncion de los accidentes se mantienen em cotas adecuadas y los paga quien razonablemente deba hacerlo, es muy probable que las decisiones econômicas favorezcan la reducción de los costos de los accidentes. Sin embargo, comoquiera que esta ideia de prevención entendida como disuasión, ha sido acuñada por los analistas económicos". 
Na vizinha Argentina, ${ }^{164}$ em parte adepta ao Direito de Danos, decorre também ampla abordagem do tema função. Mosset Iturraspe, além da função reparatória, indica a prevenção, a sanção e a adjudicação como alternativas funcionais integrantes do campo obrigacional de seu país. ${ }^{165}$

Em Portugal, Menezes Cordeiro, aprofundando nos escopos da responsabilidade civil, assevera que a função ressarcitória tornou-se fim meramente linear, o que contrapõe à responsabilidade penal que adotou a prevenção e a retribuição para estancar melhor a delinquência. Por isso, na atualidade busca-se a operacionalidade de demais funções, notadamente preventiva e sancionatória, como forma de restituir ao cidadão a confiança no sistema normativo. ${ }^{166}$

A tendência à diversificação de funções também se faz presente no sistema common law. Nesse sentido, Markesinis, Deakin e Angus destacam que as funções da "law of torts" têm se modificado em cada contexto histórico e conforme as tendências socioeconômicas e filosóficas do momento, destacando a justiça, punição, dissuasão, compensação, repartição de custos entre outros. Contudo, na opinião dos mencionados autores, nenhuma delas isoladamente oferece uma justificação completa para a responsabilidade civil, e a proeminência de uma ou outra função depende dos diferentes estágios de desenvolvimento da matéria. ${ }^{167}$

164. Entre outros: LORENZETTI, Ricardo Luis. Fundamentos do direito privado. São Paulo: Revista dos Tribunais, 1998; CALVO COSTA, Carlos A. Daño resarcible. Buenos Aires: Hammurabi, 2005. GHERSI, Carlos Alberto. Reparación de daños. Buenos Aires: Editorial Universidad, 1989. ZANNONI, Eduardo A. El daño en la responsabilidad civil. $2^{\text {a }}$ ed. Buenos Aires, 1993. LÓPEZ CABANA, Roberto M. Responsabilidad civil por acidentes. Buenos Aires: Abeledo-Perrot, 1998.

165. MOSSET ITURRASPE, Jorge; PIEDECASAS, Miguel A. Responsabilidad por daños. Tomo XI. Santa Fe: Rubinzal-Culzoni, 2009, p.19. Adverte que: "Desde distintos ângulos se han puesto en duda las funciones tradicionales o clásicas de la responsabilidad: la sancionatória y la reparatória, buscando poner el acento en aspectos que tienen que ver con 'la seguridad social', con el reproche a la conciencia o el pecado, con un enfoque socioeconómico o interpretación económica, con en reparto del perjuicio o justicia distributiva, y se ha ido perdiendo de vista la situación básica: la de la víctima inocente de un daño injustamente sofrido".

166. MENEZES CORDEIRO, António. Tratado de Direito Civil Português. Direito das obrigações. Tomo III. $3^{\text {a }}$ ed. Coimbra: Almedina, 2010, p.421.

167. MARKESINIS, Basil; DEAKIN, Simon; ANGUS, Johnston. Tort Law. Seventh edition. Oxford: Oxford University Press, 2013, p.43: "The aim of the law of tort have changed throughout its history: appeasement, justice, punishment, deterrence, compensation, and loss-spreading can be counted amongst them. None of them has offered a complete justification for the law. [...] Overall, however, it can be said with some measure of confidence that at different stage of development of tort law one of its functions may have been more proeminent than the rest. Moreover, each of its historical setting reveals something about the socio-economic and philosophical trends of the day." 
No Brasil, desde a edição do atual Código Civil, houve o despertar da doutrina acerca do problema das funções, originando ampla fonte de pesquisas ${ }^{168}$ que abordam a interface entre o princípio constitucional da solidariedade e a função social do contrato, bem como a função social da propriedade, resgatando o manancial teleológico quanto aos fins sociais na aplicação da lei, conforme já determinava o art. $5^{\circ}$ da Lei de Introdução às Normas do Direito Brasileiro de 1942, bem como já manifestava a doutrina alemã do início do século XX. ${ }^{169}$

No entanto, para a responsabilidade civil, mesmo que esteja compreendido, entre outros, idêntico axioma constitucional que informa o contrato e a propriedade - o solidarismo, não cuidou a doutrina em transformá-la exclusivamente numa 'função social', sob o risco de mitigação das amplas e necessárias possibilidades desse instituto obrigacional no enfretamento de seu principal mote: o neminem laedere.

Saliente-se entre os autores que estudam o Direito brasileiro, inicialmente, Fernando Noronha, que divide a responsabilidade civil entre uma finalidade estática, na proteção da esfera jurídica de cada pessoa naquilo que corresponda à expectativa de preservação da situação atual, e outra dinâmica onde afloram outras funções como a sancionatória (punitiva) ou preventiva (dissuasória). ${ }^{170}$

Vale ampla divulgação o pioneirismo de Teresa Ancona Lopez, ${ }^{171}$ muito bem traduzido em sua tese de titularidade na cadeira de Direito civil na Universidade de São Paulo, quando evoluindo a precaução como princípio no Direito privado brasileiro,

168. Um estudo profundo pode ser consultado em RUZIK, Carlos Eduardo Pianovski. Liberdade(s) e função: contribuição crítica para uma nova fundamentação da dimensão funcional do Direito Civil brasileiro. Tese de Doutorado. Universidade Federal do Paraná. Curitiba. 2009. Disponível em: http://dspace.c3sl.ufpr.br/dspace/bitstream/handle/1884/19174/Carlos_Eduardo_Tese_completa\%5B1 \%5D.pdf? sequence=1. Acesso: 09 set. 2013.

169. GIERKE, Otton. La función del derecho privado: la natureza de las asociaciones privadas. Trad. José M. Navarro Palencia. Madrid: Sociedad Editorial Española, 1904.

170. NORONHA, Fernando. Direito das obrigações. Vol. 1. $2^{\text {a }}$ ed. São Paulo: Saraiva, 2007, p.435.

171. LOPEZ, Teresa Ancona. Princípio da precaução e evolução da responsabilidade civil. São Paulo: Quartier Latin, 2010, p.17. Explica em seu texto: “O princípio da precaução, que tem como fundamento ético a prudência e jurídico a obrigação geral de segurança, deverá, doravante, fazer parte da responsabilidade civil, e esse ramo do direito passa a ter três funções: a função compensatória (reparação integral); a função dissuasória (deterrence), que aparece através das indenizações pesadas contra o autor do dano (essa função é chamada de preventiva ainda hoje); a função preventiva, em sentido lato, englobando os princípios da precaução e da prevenção, pela qual haverá a antecipação de riscos e danos". 
fundamentou-a eticamente pela prudência e juridicamente na obrigação de segurança, justificando três funções para a responsabilidade civil: compensatória, dissuasória e preventiva (antecipação de riscos e danos).

De todo esse panorama ilustrativo, é possível perceber que a técnica exclusivamente reparatória, que tradicionalmente corresponde à função essencial da responsabilidade civil, cedeu espaço à absorção de funções diversas nos variados ordenamentos jurídicos de civil law, bem como de common law. Isso decorre do deslocamento de prioridades no sistema jurídico, que por sua vez evidenciou a exaustão do sistema reparatório, provocando aquele instituto a assumir diversificadas funções, entre elas, a proposta de também atuar como instrumento capaz de gerenciar riscos e evitar a ocorrência de danos graves. Assim, além de manter a sua função básica, outras lhe foram acrescentadas, e "a responsabilidade civil passa a se preocupar com as questões que estão por vir, todavia, sem olvidar da necessidade de reparação dos danos já ocasionados". ${ }^{172}$

A insuficiência da função reparatória em lidar com necessidades típicas da pós-modernidade, consoante será tratado no próximo capítulo, de certa forma, provocou uma perplexidade doutrinária, que arraigada na concepção estrutural clássica da responsabilidade civil, tende a permanecer refratária à absorção de novas funções por esse instituto. A necessidade de desconstrução dessa rigidez e as possibilidades do instituto atuar também com caráter preventivo prospectivo serão abordadas a seguir.

Assim, aos operadores do Direito abre-se a perspectiva de nova interpretação e melhor instrumentalidade para lidar com a questão atinente à problemática dos riscos, através da aplicação em harmonia dos princípios estruturantes da responsabilidade civil em suas feições reparatória e preventiva - Princípio da reparação integral, Princípio da prevenção e Princípio da precaução.

172. LEITE, José Rubens Morato; AYALA, Patryck de Araújo. Dano ambiental: do individual ao coletivo extrapatrimonial. $4^{\text {a }}$ ed. São Paulo: RT, 2011, p.138. 


\subsection{A INSUFICIÊNCIA DA FUNÇÃO REPARATÓRIA E O ESTABELECIMENTO DE UMA FUNÇÃO PREVENTIVA PROSPECTIVA DA RESPONSABILIDADE CIVIL}

É possível constatar que a responsabilidade civil na atualidade perpassa uma situação de crise, seja porque determinados setores antes regulados por ela cederam frente à socialização dos riscos por mecanismos de securitização, seja porque o instituto passou a assumir funções heterogêneas.

Com essa visão, Cesare Salvi dedica um capítulo de sua obra a estudar "Il paradosso della responsabilità civile: espansione e crisi", ${ }^{173}$ no qual aponta que a incerteza funcional se traduz em incerteza normativa e operativa, sem contudo, descartar que o destino da responsabilidade civil tende irreversivelmente a um processo de diversificação, situando entre opostos extremos a função solidarista prevalente no campo dos danos à pessoa, aonde atuam de forma privilegiada a responsabilidade objetiva e a securitização, e de outro, a revitalização das funções de prevenção e de punição, em uma pluralidade de modelos articulados de forma funcional e operativa.

Também destacando a crise que perpassa a responsabilidade civil, Francesco D. Busnelli e Salvatore Patti fazem referência a "La parábola della responsabilità civile", ${ }^{174}$ para os quais o momento presente representa provavelmente o seu ápice. Isso porque, consideram os juristas italianos, a expansão das fronteiras da responsabilidade civil corresponde a uma máxima multiplicidade de funções e o máximo grau de erosão dos elementos estruturais da teoria geral da responsabilidade civil, do que resulta um quadro, de um lado, reconfortante, considerando-se a transformação da

173. La responsabilità civile. Milano: Dott. A. Giuffrè Editore, 2005, p.310 e 322.

174. Danno e responsabilità civile. Terza Edizione. Torino: G. Giappichelli Editore, 2013, p.148. Em tradução livre, sintetizando "quarenta anos de estudos sobre a responsabilidade civil": "Um curso de água, alimentado por uma fonte antiga, atravessa um grande território influenciando a sua exploração econômica. Com a transição de uma agricultura de subsistência para um intenso desenvolvimento industrial, o fluxo de água se revela insuficiente, de modo que os especialistas engenhosamente promovem a construção de barragens, canais e outros artefatos, a fim de melhor aproveitamento e distribução da escassa água disponível. Mas, de repente, o rio se enche, pela confluência de uma série de fluxos de lama provenientes de novas fontes. Assim que, agora, os especialistas são chamados a trabalhar para conter a água, a fim de evitar transbordamentos e inundações. Metaforicamente . O fluxo de água representa a evolução da responsabilidade civil, e o território atravessado corresponde à experiência de direito privado. 
tradicional rigidez interpretativa e aplicativa das normas sobre responsabilidade civil, tornando o instituto um dos mais dúcteis de todo o Direito privado; e de outro lado, preocupante, tendo em vista a incoerência sistemática que atravessa a responsabilidade civil, seja no aspecto funcional, seja no estrutural. ${ }^{175}$

Essa situação igualmente é evidenciada por diversos juristas no Brasil. Anderson Schreiber, ${ }^{176}$ por exemplo, destaca a "erosão dos filtros da reparação", quais sejam, o "ocaso da culpa" e a "flexibilização do nexo causal" como um choque entre velhas estruturas e novas funções assumidas pela responsabilidade civil. Em semelhante entendimento, Maria Celina Bodin de Moraes $^{177}$ destaca que a estrutura da responsabilidade civil converteu-se em um amálgama de funções atribuídas pela jurisprudência, que ainda carecem de sistematização doutrinária, sobretudo no tocante à indenização por dano moral. De igual forma, Judith Martins-Costa ${ }^{178}$ salienta que a multiplicidade de funções da responsabilidade civil é hoje um grande problema, que decorre da tensão entre a plasticidade do instituto e as novas necessidades sociais, agregando funções diversas à tradicional função de restauração dos danos ilicitamente causados.

Sem descurar os fatos e os argumentos que evidenciam um olhar crítico sobre a expansão da responsabilidade civil atual, convém destacar as insuficiências da função exclusivamente reparatória no contexto pós-moderno.

Inicialmente, deverão ser avaliados os altos custos e ineficiência do sistema judicial de reparação de danos, que englobam, além da indenização propriamente dita,

175. Francesco D. Busnelli e Salvatore PATTI. Danno e responsabilità civile. Terza Edizione. Torino: G. Giappichelli Editore, 2013, p.164 et seq. Apontam as possíveis causas do desenvolvimento distorcido que atravessa a responsabilidade civil, nos planos funcional e estrutural: "l'indirizzo poggiante sulla c.d. "nuova valenza costituzionale" dell'art. 2043; la tendenza all'indistinzione tra funzione risarcitoria della responsabilità civile e funzione solidaristica della sicurezza sociale; l'impiego deformante dell'impianto strutturale dell'art. 2043 per risolvere problemi di diritto pubblico; il ricorso al nomen della responsabilità civile per atribuire formale solenità a una responsabilità sostanzialmente disciplinare".

176. Novos paradigmas da responsabilidade civil: da erosão dos filtros da reparação à diluição dos danos. São Paulo: Atlas, 2007, p.5.

177. Danos à pessoa humana: uma leitura civil-constitucional por danos morais. Rio de Janeiro: Renovar, 2003, p.24.

178. Comentários ao novo Código Civil. Do inadimplemento das obrigações. Vol. V. Tomo II. $2^{\mathrm{a}}$ edição. Rio de Janeiro: Forense, 2009, p.147. 
também os honorários advocatícios, peritos, custas judiciais, entre outros.

Um estudo mencionado por Patrick Atiyah ${ }^{179}$ e Markesinis, Deakin e Angus, ${ }^{180}$ com relação ao sistema inglês e com dados apontados pela Pearson Commission, indicam que para arcar com duzentas mil libras de indenização, o custo administrativo era de cento e setenta e cinco mil libras. Embora referido estudo seja datado de 1978 e refirase ao contexto britânico, essa realidade não parece tão apartada dos sistemas de civil law, tampouco do ambiente brasileiro, cuja morosidade percebida pelo senso comum do jurisdicionado é capaz de indicar, à míngua de um estudo estatístico apurado para diagnosticar a questão, que grande parte do numerário destinado ao ajuizamento de uma ação de indenização não é levado ao benefício da vítima.

Diante disso, a preocupação com a vítima e a necessidade de que a indenização tenha um percurso célere, fez com que as propostas de substituição ou complementação da responsabilidade civil com mecanismos de seguridade social ou seguro de responsabilidade civil alcançassem ampla adesão.

De outro lado, determinadas categorias de danos são capazes de demonstrar a falácia do retorno ao status quo ante.

Com efeito, restituir a vítima ao estado anterior ao dano, restabelecendo o equilíbrio social, é exigência natural de justiça comutativa, cuja observação remonta à ética aristotélica. ${ }^{181}$ Para tanto, informado pelo Princípio da Reparação Integral, o sistema de responsabilidade civil reparatório ex post dano trabalha com duas categorias: a da reparação natural, em que se busca restituir à vítima o exato bem sobre o qual incidiu o prejuízo, colocando-a o mais próximo possível da situação que antecedeu a ocorrência do dano, seja através da recomposição pela mesma coisa danificada ou sua substituição por

179. The dammages lottery. Oxford: Hart Publishing, 1997, p.153.

180. MARKESINIS, Basil; DEAKIN, Simon; ANGUS, Johnston. Tort Law. Seventh edition. Oxford: Oxford University Press, 2013, p.4: “These represent the so called 'private costs', i. e. the sums tranferred from the defendant (or his insurer) to the claimant to 'compensate' the latter for his injuries. In addition, however, one must bear in mind that there are additional 'social costs'. These include administrative costs needed to make the transfer payments. The amounts of these administrative costs are high and, indeed, in the cases considered here amounted to nearly double the sums actually paid over to the victims".

181. ARISTÓTELES. Ética a Nicômaco. Trad. Mario da Gama Kury. Brasília: Ed. Universidade de Brasília, 1992, p.99. 
outra; e o da indenização pecuniária, entregando à vítima um valor em dinheiro correspondente aos danos sofridos pela mesma.

A primazia de uma ou outra categoria de reparação depende da opção e tradição de cada ordenamento jurídico. ${ }^{182}$

No Brasil, a reparação in natura é incentivada em determinadas situações, como por exemplo, na esfera do Direito ambiental - arts. $4^{\text {o }}$, VI e VII ${ }^{183}$ e art. $14, \S 1^{\text {o184 }}$ da Lei 6.938/81; art. $225, \S 2^{\circ}$ e $\S 3^{\circ},{ }^{185}$ da Constituição Federal, e ainda arts. $3^{\circ}$ e $11^{186}$ da Lei 7.347/85 -, tendo em vista que a melhor lição ambiental sustenta que "a reparação concreta do meio ambiente degradado é sempre preferível ao pagamento de indenização". ${ }^{187}$

Convém observar que até mesmo quando a reparação é pecuniária, fixada

182. Anota Paulo de Tarso Vieira SANSEVERINO, com apoio em Geneviève Viney, que há sistemas em que há ampla primazia da condenação pecuniária e em que a reparação natural apresenta um papel acessório, como a Inglaterra, os Estados Unidos e os países escandinavos. De outro lado, refere os países em que a respectiva legislação atribui um papel prioritário à reparação natural em relação à condenação em perdas e danos, como ocorre com o Código Civil alemão, que, nesse ponto, foi imitado pelo austríaco, pelo suíco e pelo português. Princípio da reparação integral: indenização no Código Civil. São Paulo: Saraiva, 2010, p.42.

183. Lei 6938/81 - Art $4^{\circ}$ - A Política Nacional do Meio Ambiente visará: (...) VI - à preservação e restauração dos recursos ambientais com vistas à sua utilização racional e disponibilidade permanente, concorrendo para a manutenção do equilíbrio ecológico propício à vida; VII - à imposição, ao poluidor e ao predador, da obrigação de recuperar e/ou indenizar os danos causados e, ao usuário, da contribuição pela utilização de recursos ambientais com fins econômicos.

184. Lei 6938/81 - Art 14 - Sem prejuízo das penalidades definidas pela legislação federal, estadual e municipal, o não cumprimento das medidas necessárias à preservação ou correção dos inconvenientes e danos causados pela degradação da qualidade ambiental sujeitará os transgressores: (...) $\S 1^{\circ}$ - Sem obstar a aplicação das penalidades previstas neste artigo, é o poluidor obrigado, independentemente da existência de culpa, a indenizar ou reparar os danos causados ao meio ambiente e a terceiros, afetados por sua atividade. O Ministério Público da União e dos Estados terá legitimidade para propor ação de responsabilidade civil e criminal, por danos causados ao meio ambiente.

185. CF/88 - Art. 225. Todos têm direito ao meio ambiente ecologicamente equilibrado, bem de uso comum do povo e essencial à sadia qualidade de vida, impondo-se ao Poder Público e à coletividade o dever de defendê-lo e preservá- lo para as presentes e futuras gerações. (...) $\S 2^{\circ}$ - Aquele que explorar recursos minerais fica obrigado a recuperar o meio ambiente degradado, de acordo com solução técnica exigida pelo órgão público competente, na forma da lei. $\S 3^{\circ}$ - As condutas e atividades consideradas lesivas ao meio ambiente sujeitarão os infratores, pessoas físicas ou jurídicas, a sanções penais e administrativas, independentemente da obrigação de reparar os danos causados.

186. Lei 7347/85 - Art. $3^{\circ}$ A ação civil poderá ter por objeto a condenação em dinheiro ou o cumprimento de obrigação de fazer ou não fazer; Art. 11. Na ação que tenha por objeto o cumprimento de obrigação de fazer ou não fazer, o juiz determinará o cumprimento da prestação da atividade devida ou a cessação da atividade nociva, sob pena de execução específica, ou de cominação de multa diária, se esta for suficiente ou compatível, independentemente de requerimento do autor.

187. LEMOS, Patrícia Faga Iglecias. Direito ambiental: responsabilidade civil e proteção ao meio ambiente. 3. ed. rev., atual. e ampl. São Paulo: Editora Revista dos Tribunais, 2010, p.209. 
em decorrência de ação civil pública, conforme previsão do art. $13^{188}$ da Lei 7.347/85, o seu montante é destinado ao estabelecimento de um fundo especial, e os recursos destinados ao restabelecimento dos bens lesados, em privilégio da reparação natural.

Embora por força do disposto no art. $947^{189}$ do Código Civil seja reservado um espaço para a reparação in natura no Direito brasileiro, de outro lado, quando houver extrema dificuldade ou impossibilidade de se reparar de forma específica, prevalecerá o sistema de indenização em dinheiro, cuja quantificação na atuação jurisdicional deve observar o disposto no art. $944^{190}$ do Código Civil. Assim, tratando-se de indenização pecuniária, esta deve ser equivalente ao total do dano ocasionado.

Referido dispositivo legal guarda o conteúdo expresso no Princípio da Reparação Integral e sua extensão, identificada por suas três funções fundamentais compensatória, indenitária e concretizadora -, na autorizada lição de Paulo de Tarso Vieira Sanseverino:

A plena reparação do dano deve corresponder à totalidade dos prejuízos efetivamente sofridos pela vítima do evento danoso (função compensatória), não podendo, entretanto, ultrapassá-los para evitar que a responsabilidade civil seja causa para o enriquecimento injustificado do prejudicado (função indenitária), devendo-se estabelecer uma relação de efetiva equivalência entre a indenização e os prejuízos efetivos derivados dos danos com avaliação em concreto pelo juiz (função concretizadora do prejuízo real). ${ }^{191}$

É inegável que o ordenamento jurídico brasileiro, assim como grande parte dos sistemas jurídicos estrangeiros, ${ }^{192}$ prestigia como proeminente a função reparatória da responsabilidade civil e o seu princípio correspondente, ao assegurar, na medida do

188. Lei 7347/85 - Art. 13. Havendo condenação em dinheiro, a indenização pelo dano causado reverterá a um fundo gerido por um Conselho Federal ou por Conselhos Estaduais de que participarão necessariamente o Ministério Público e representantes da comunidade, sendo seus recursos destinados à reconstituição dos bens lesados.

189. Código Civil - Art. 947. Se o devedor não puder cumprir a prestação na espécie ajustada, substituir-se-á pelo seu valor, em moeda corrente.

190. Código Civil - Art. 944. A indenização mede-se pela extensão do dano.

191. Princípio da reparação integral: indenização no Código Civil. São Paulo: Saraiva, 2010, p.58.

192. VINEY, Geneviève; JOURDAIN, Patrice. Traité de Droit Civil: Les effets de la responsabilité. $3^{\text {e }}$ éd. Paris: LGDJ, 2010, p.154: "Cette règle est admise dans la plupart des systèmes juridiques. Elle est consacrée par de nombreuses conventions et déclarations internationales et son adoption a été proposée par les différents projets d'harmonisation des droits privés européens. Elle est également appliquée couramment par les arbitres internationaux". 
possível, uma relação de equivalência entre a indenização e o dano sofrido. Corolário dessa posição é a não permissibilidade de métodos de tarifação abstrata de indenização, ${ }^{193}$ deixando a cargo do magistrado, diante das circunstâncias de fato evidenciadas, o estabelecimento do quantum debeatur. Esse, inclusive, foi o entendimento consolidado no Enunciado 550, da VI Jornada de Direito Civil: “A quantificação da reparação por danos extrapatrimoniais não deve estar sujeita a tabelamento ou a valores fixos." 194

O Princípio da Reparação Integral também atua, ainda, repelindo que a indenização seja caracterizada como fonte de enriquecimento sem causa (art. 884, ${ }^{195}$ Código Civil), afastando, a priori, o estabelecimento de uma função punitiva nos moldes da punitive damages típica do regime de torts do Direito anglo-americano. Esse entendimento, contudo, está longe de encontrar uma posição unânime, por razões culturais e jurídicas que não caberiam ser discutidas em profundidade no espaço desta pesquisa, ${ }^{196}$ sendo que ora percebe-se uma interpretação restritiva do art. 944 do Código Civil, ${ }^{197}$ em outros momentos, uma interpretação ampliativa, ${ }^{198}$ tal qual a redação consolidada no

193. A indenização fixada pela Lei de Imprensa (Lei $\left.n^{\circ} 5250 / 67\right)$, por exemplo, já serviu como norte para o arbitramento das indenizações. Com a entrada em vigor da Súmula 281 do STJ, dirimiram-se quaisquer dúvidas a respeito de sua aplicação: "A indenização por dano moral não está sujeita à tarifação prevista na Lei de Imprensa".

194. VI Jornada de direito civil: enunciados aprovados. Coordenador científico Ministro Ruy Rosado de Aguiar Júnior. Brasília: Conselho da Justiça Federal, Centro de Estudos Judiciários, 2013. Disponível em: http://www.cjf.jus.br/cjf/CEJ-Coedi/jornadas-cej/vijornada.pdf. Acesso: 01 de agosto de 2013.

195. Códigio Civil - Art. 884. Aquele que, sem justa causa, se enriquecer à custa de outrem, será obrigado a restituir o indevidamente auferido, feita a atualização dos valores monetários.

196. Entre os autores estrangeiros, válida é a pesquisa em: LOURENÇO, Paula Meira. A função punitiva da responsabilidade civil. Coimbra: Coimbra, 2006, p.17-24; GALLO, Paolo. Pene private e responsabilità civile. Milano: Giuffrè, 1996, p.37-58; BUSNELLI, Francesco D.; SCALFI, Gianguido (a cura di). Le pene private. Milano: Dott. A. Giuffrè Editore, 1985, p.293-345; CARVAL, Suzanne. La responsabilité civile dans sa fonction de peine privée. Paris: L.G.D.J, 1995, p.1-43.

197. Para uma investigação mais precisa entre os autores brasileiros, consulte-se, entre outros, LEVY, Daniel de Andrade. Responsabilidade civil: de um direito dos danos a um direito das condutas lesivas. São Paulo: Atlas, 2012, p.33-123; MORAES, Maria Celina Bodin de. Danos à pessoa humana: uma leitura civil-constitucional dos danos morais. Rio de Janeiro: Renovar, 2003, p.193-264; LEVY, Daniel de Andrade. Uma visão cultural dos punitive damages. Revista de Direito Privado. Vol. 45. Janeiro-Março 2011, p.163; MARTINS-COSTA, Judith; PARGENDLER, Mariana Souza. Usos e abusos da função punitiva (punitive damages e o direito brasileiro). Disponível em http:// www2.cjf.jus.br/ojs2/index.php/revcej/article/viewArticle/643. Acesso: 15 jul. 2013; ROSENVALD, Nelson. As funções da responsabilidade civil: a reparação e a pena civil. São Paulo: Atlas, 2013, p.139-222.

198. No Brasil, consulte-se VAZ, Caroline. Funções da responsabilidade civil: da reparação à punição e dissuação. Porto Alegre: Livraria do Advogado, 2009, p.41 et seq; BENACCHIO, Marcelo. A função punitiva da responsabilidade civil no Código Civil. In: LOTUFO, Renan; NANNI, Giovanni Ettore; MARTINS, Fernando Rodrigues (coord.). Temas relevantes do direito civil contemporâneo: reflexões sobre os 10 anos do Código Civil. São Paulo: Atlas, 2012, p.641-668. 
Enunciado no 379 da IV Jornada de Direito Civil: “O art. 944, caput, do Código Civil não afasta a possibilidade de se reconhecer a função punitiva ou pedagógica da responsabilidade civil". ${ }^{199}$

Sob essa ótica, a função reparatória da responsabilidade civil também é confrontada em decorrência da admissão desse instituto como mecanismo de salvaguarda aos valores essenciais das pessoas, o seu bem-estar, a qualidade de vida e o desenvolvimento das potencialidades humanas. Nessa conotação, a noção jurídica de dano abandona o sentido marcadamente patrimonial, e passa a ser concebido também como violação aos interesses que decorrem da personalidade. ${ }^{200}$ A Constituição Federal de 1988 contribuiu significativamente para essa personalização do Direito, ao contemplar a dignidade da pessoa humana como fundamento (art. $1^{\circ}$, inciso III), além de expressamente assegurar indenização por "danos morais" decorrente de violação a direitos fundamentais como a intimidade, vida privada, honra e imagem das pessoas (art. $5^{\circ}$, inciso X).

Logo, frente à impossibilidade de reposição do bem violado ao seu estado anterior, o critério apontado pela teoria da diferença (Diferenztheorie) ${ }^{201}$ para fixação da indenização por danos foi ultrapassado, e passou-se a admitir a função satisfatória ${ }^{202}$ da

199. Jornadas de direito civil: enunciados aprovados. Coordenador científico Ministro Ruy Rosado de Aguiar Júnior. Brasília: Conselho da Justiça Federal, Centro de Estudos Judiciários, 2012. Disponível em: http://www.cjf.jus.br/cjf/CEJ-Coedi/jornadas-cej/enunciados-aprovados-da-i-iii-iv-e-v-jornada-dedireito-civil/compilacaoenunciadosaprovados1-3-4jornadadircivilnum.pdf. Acesso: 01 de agosto de 2013.

200. “[...] Torna-se cada vez mais claro que não basta tutelar a aspiração (inquestionavelmente legítima) de conservação da vida, ínsita do ser humano, mas reconhece-se como legítima, igualmente, e digna de tutela o desejo que cada ser humano tem de usufruir a vida, concretizar seus projetos e suas realizações [...] Há um deslocamento, uma nova inflexão da responsabilidade: o direito passa a ocupar-se não mais da responsabilidade da pessoa (culpa), mas da responsabilidade para com a pessoa. Segue-se que os direitos da personalidade consagrarão a proteção da pessoa face à sociedade e, ainda, vislumbra-se que a responsabilidade civil não pertence somente ao terreno patrimonial, é também um direito da pessoa." HOFMEISTER, Maria Alice Costa. O dano pessoal na sociedade de risco. Rio de Janeiro: Renovar, 2002, p.90-91.

201. ALVIM, Agostinho. Da inexecução das obrigações e suas consequências. 5 ed. São Paulo: Saraiva, 1980, p.214, explica: "A teoria, chamada "do interesse", ou "da diferença", acolhe a ideia de dano em relação ao patrimônio de quem o sofreu. A verificação do dano dá-se mediante uma operação que Fischer resume, mandando comparar 'a situação real do patrimônio depois de se ter verificado o evento danoso, com o estado imaginário que apresentaria se este se não houvesse produzido. A diferença negativa encontrada revela a existência do dano e exprime a sua extensão"”.

202. “[...] No caso específico dos danos extrapatrimoniais, em face da dificuldade de se quantificar a indenização correspondente, a função preponderante é satisfatória, visto que não é possível estabelecer uma precisa relação de equivalência entre os prejuízos sem conteúdo econômico e a reparação pecuniária." SANSEVERINO, Paulo de Tarso Vieira. Princípio da reparação integral: indenização no Código Civil. São Paulo: Saraiva, 2010, p.271. 
responsabilidade civil, que visa atribuir à vítima alguma compensação ou benefício de ordem material que possa contrabalançar o dano extrapatrimonial sofrido. Os danos verificados na esfera dos interesses imateriais também demonstram a insuficiência da função exclusivamente reparatória ao promover o desenvolvimento, sobretudo pela via jurisprudencial, de uma função punitivo-pedagógica ${ }^{203}$ com relação à fixação do montante da indenização, malgrado posicionamentos discordantes.

Convém explicitar que, mesmo entre aqueles que não admitem a adequação da função punitiva do dano moral no ordenamento jurídico brasileiro, hipóteses excepcionais de aplicação, taxativamente previstas em lei, devem ser consideradas, como no disposto no art. 13 da Lei $n^{\circ} 7.347 / 85$, aplicável a situações potencialmente causadoras de danos a um universo coletivo ou difuso, como nas relações de consumo ou Direito ambiental, pois nesse caso, “a ratio será a função preventivo-precautória, que o caráter punitivo inegavelmente detém, em relação às dimensões do universo a ser protegido". ${ }^{204}$ Trata-se do pagamento de uma multa a ser recolhida a um fundo público.

De outro lado, a dinâmica da vida pós-moderna e os novos modelos sociais decorrentes do desenvolvimento tecnocientífico e incremento do consumo, causadores de novos riscos à medida que inovadoras técnicas e produtos são disponibilizados, demonstram que a função reparatória não é suficiente, em inúmeras situações, para o restabelecimento da equivalência e justiça entre vítima e lesante, e principalmente, é falha ao garantir o alcance de segurança (na saúde, nos produtos de consumo, na alimentação, nos medicamentos, na preservação do meio ambiente, entre outros), tipicamente desejada pelas gerações humanas na contemporaneidade.

Os danos identificados na pós-modernidade apresentam traços peculiares,

203. Exemplificativamente: Brasil - Superior Tribunal de Justiça, AgRg no REsp 1373969/RS, Relator Ministro Sidnei Beneti, Data do julgamento 28/05/2013. Ementa: "AGRAVO REGIMENTAL. PLANO DE SAÚDE. ILEGALIDADE DA NEGATIVA DE COBERTURA A TRATAMENTO. DANO MORAL CONFIGURADO. DECISÃO AGRAVADA MANTIDA. IMPROVIMENTO. 1.- É pacífica a jurisprudência da Segunda Seção no sentido de reconhecer a existência do dano moral nas hipóteses de recusa pela operadora de plano de saúde, em autorizar tratamento a que estivesse legal ou contratualmente obrigada, sem que, para tanto, seja necessário o reexame de provas. 2.- A fixação dos danos morais no patamar de $\mathrm{R} \$$ 5.000,00 (cinco mil reais), cumpre, no presente caso, a função pedagógico- punitiva de desestimular o ofensor a repetir a falta, sem constituir, de outro lado, enriquecimento indevido. 3.- Agravo Regimental improvido."

204. MORAES, Maria Celina Bodin de. Danos à pessoa humana: uma leitura civil-constitucional dos danos morais. Rio de Janeiro: Renovar, 2003, p.263. 
que os distinguem dos danos convencionais tratados pela responsabilidade civil reparatória, moldada como exigência de reação a um prejuízo que atingisse a esfera individual e patrimonial do indivíduo, o que impõe uma remodelação para lidar com as suas especificidades e conferir maior efetividade ${ }^{205}$ à responsabilidade civil.

Para esse entendimento, concorre a constatação já identificada em capítulo anterior de que a incerteza e irreversibilidade são elementos inerentes do dano na sociedade de risco. Nesse caso, Teresa Ancona Lopez avalia que "a função reparadora se esvazia diante do irreparável e essa constatação impulsiona a prevenção e a precaução como princípios da responsabilidade civil". ${ }^{206}$

De fato, vivencia-se, na sociedade contemporânea, uma categoria de danos que não se adequa perfeitamente à configuração clássica da responsabilidade civil, pois diversamente dos danos convencionais, que se verificam no plano intersubjetivo, os "novos danos" (especialmente com relação aos interesses da coletividade) se caracterizam de forma supra individual, podendo, de forma reflexiva, atingir direitos e bens individuais. Quanto aos "bens de incidência coletiva", 207 a dificuldade em sua quantificação e apreciação econômica justifica a precedência da prevenção do dano, seguida da restituição, e somente não havendo êxito nestas possibilidades, buscar a reparação.

Além disso, há danos que decorrem de uma pluralidade de condutas, não havendo como determinar os seus autores através dos mecanismos causais clássicos de

205. Ao tratar especificamente da responsabilidade civil na proteção do meio ambiente, Antônio Herman de Vasconcelos e BENJAMIN aponta quatro causas para a rejeição de uma responsabilidade civil mais eloquente nesta seara: "a) as funcionais (a tradicional visão da responsabilidade civil como instrumento post factum, destinado à reparação e não à prevenção de danos, b) as técnicas (inadaptabilidade do instituto à complexidade do dano ambiental, exigindo, p.ex., um dano atual, autor e vítima claramente identificados, comportamento culposo e nexo causal estritamente determinado), as éticas (na hipótese de terminar em indenização - sendo impossível a reconstituição do bem lesado - a responsabilidade civil obriga, em última análise, a agregar-se um frio valor monetário à natureza, comercializando-a como tal), e d) as acadêmicas (de um lado, uma tendência monopolista e egoísta da doutrina do Direito Público, enxergado a proteção do meio ambiente como seu domínio exclusivo; de outro, uma timidez injustificável da jusprivatística, abdicando de intervir em tão nuclear hemisfério da danosidade humana)". Responsabilidade civil pelo dano ambiental no direito brasileiro e as lições do direito comparado. Disponível em $<$ http://bdjur.stj.jus.br/xmlui/bitstream/handle/2011/8632/A_Responsabilidade\%20_Civil.pdf;jsessioni $\mathrm{d}=46 \mathrm{ED} 2 \mathrm{C} 19 \mathrm{~A} 1 \mathrm{E} 65 \mathrm{~F} 4744 \mathrm{ACD} 46 \mathrm{CF} 328 \mathrm{~F} 175$ ? sequence=3>. Acesso em: 25 set. 2013.

206. Princípio da Precaução e Evolução da Responsabilidade Civil. São Paulo: Quartier Latin, 2010, p.121.

207. LORENZETTI, Ricardo Luis. Teoria geral do direito ambiental. Trad. Fábio Costa Morosini e Fernanda Nunes Barbosa. São Paulo: RT, 2010, p.23. 
responsabilização. Importante, ainda, considerar que as manifestações de certos danos projetam-se no tempo ${ }^{208}$ e no espaço, o que dificulta a sua efetiva constatação e delimitação, bem como a identificação das gerações de vítimas, sejam elas presentes ou futuras. Essas peculiares características de danosidade, já identificadas pelas ciências sociais, demandam novos mecanismos de regulação jurídica, para que a eficácia de segurança e proteção que decorre das normas do Direito não esteja ameaçada.

Por todo o exposto, é forçoso concluir, na esteira das observações expostas por Geneviève Viney e Patrice Jourdain, ${ }^{209}$ que o Princípio da Reparação Integral, informador da função reparatória da responsabilidade civil, embora apresente como vantagens a capacidade de modulação a situações particulares e seja perfeitamente adaptado aos danos patrimoniais, não é capaz de erigir-se como o único critério orientador dos magistrados para a avaliação de danos, devendo ser considerados também outros imperativos. $^{210}$

Ao considerar perspectivas diversas que conduzem à atribuição de objetivos distintos da reparação como consequência da evolução da ideia de responsabilidade civil, os autores franceses ${ }^{211}$ enumeram: a utilização da responsabilidade civil como pena privada; a utilização do instituto como meio de prevenir a realização de danos que ameaçam se produzir, para os quais a ideia de reparação orientada ao passado seria

208. Cabe mencionar a correlação entre tempo risco e direito, estabelecida por AYALA, Patrick de Araújo. A proteção jurídica das futuras gerações na sociedade de risco global. In: LEITE, José Rubens Morato; FERREIRA, Heline Sivini; BORATTI, Larissa Verri. Estado de direito ambiental: tendências. 2. Ed. Rio de Janeiro: Forense Universitária, 2010, p.326-327: “O tempo é, nas sociedades de risco, elemento que define a forma como a própria sociedade se organiza, e que também modifica a própria forma de organização do sistema jurídico, propondo necessidades, objetivos e valores diferenciados para o exercício da atividade de regulação normativa e de proteção jurídica do ambiente, que hoje precisa organizar, justificar e fundamentar respostas (decisões) sobre problemas com referência a vínculos estabelecidos com o futuro, e a partir de contextos de decisão organizados em torno de riscos.”

209. Traité de Droit Civil: Les effets de la responsabilité. $3^{\mathrm{e}}$ éd. Paris: LGDJ, 2010, p.163. Em língua original: "En définitive, la règle de la réparation intégrale, dont l'application présente dans certains cas de très grands avantages et qui possède une capacité d'adaptation irremplaçable, ne nous paraît pas cependant fournir toujours nécessairement le seul critère possible pour guider les juges dans l'évaluation des dommages-intérêts. Non seulement il nous semble nécessaire d'en limiter l'application aux seuls préjudices auxquels elle est adaptée, c'est-à-dire aux dommages de nature économique, mais en outre nous pensons que, même dans ce domaine, elle mériterait parfois d'être corrigée ou modifiée pour tenir compte d'impératifs autres que celui de l'indemnisation".

210. Em oposição às críticas expostas por Geneviève Viney e Patrice Jourdain, ver SANSEVERINO, Paulo de Tarso Vieira. Princípio da reparação integral: indenização no Código Civil. São Paulo: Saraiva, 2010, p. 79.

211. VINEY, Geneviève; JOURDAIN, Patrice. Traité de Droit Civil: Les effets de la responsabilité. $3^{\mathrm{e}}$ éd. Paris: LGDJ, 2010, p.4-42. 
insuficiente (como nos casos dos direitos de vizinhança, concorrência desleal, atentados aos direitos reais ou aos direitos da personalidade), bem como, ainda sob a ótica da prevenção, a utilização da responsabilidade civil orientada à gestão de riscos; e por fim, como reforços à eficácia da responsabilidade civil, anotam a utilização da função de restabelecimento à situação anterior ao dano e a função de cessação da ilicitude. ${ }^{212}$

Todas essas transformações e tendências denotam que a função reparatória da responsabilidade civil deve ser relativizada de acordo com a filosofia política que se adote, reconhecendo abertamente a vinculação axiológica expressada entre as funções da responsabilidade civil e a garantia de bens jurídicos fundamentais, individuais e coletivos. A proposta de interpretação da responsabilidade civil sob um viés preventivo é apoiada sobre a base do Estado Democrático de Direito, que melhor expressa um desideratum que uma realidade jurídico-positiva. Assim, ao mesmo tempo em que reflete a organização social, pretende transformar a realidade sob os influxos dos marcos constitucionais e aspiração popular, em especial com o fito de resguardar a fundamentalidade de direitos protegidos.

Com efeito, esse modelo estatal, plasmado no art. $1^{\circ}$ da Constituição Federal de 1988, erige-se sobre a base de direitos e garantias fundamentais que fixam premissas valorativas que devem inspirar toda a elaboração do Direito positivo e orientar a evolução dogmática da responsabilidade civil. De outro lado, a norma constitucional também enuncia deveres de proteção que afirmam a responsabilidade e vinculação jurídica à sua observância tanto do Poder Público como dos particulares, e enaltece a ideia de "responsabilidade comunitária dos indivíduos" e "auto responsabilidade na sua atuação social", ${ }^{213}$ não no sentido de uma responsabilidade apenas moral, mas sobretudo jurídica:

A caracterização do Estado Social e do conjunto de direitos fundamentais de segunda dimensão (sociais, econômicos e culturais) traz consigo a configuração de deveres sociais. Nesse cenário, é possível apontar, em termos gerais, para a criação de uma "consciência", um "ethos" jurídico-político de acordo com os quais o indivíduo existe para além da sua própria individualidade, caracterizando-se por ser um sujeito social responsável para com a

212. Algumas dessas tendências destacadas pelos autores franceses serão estudadas na Parte II desta tese, no que diz respeito à estruturação da Responsabilidade Civil Preventiva.

213. SARLET, Ingo Wolfgang; FENSTERSEIFER, Tiago. Direito Constitucional Ambiental: estudos sobre a Constituição, os Direitos Fundamentais e a Proteção do Ambiente. São Paulo: Editora Revista dos Tribunais, 2011, p.134. 
existência comunitária à sua volta (ou seja, de todos os integrantes do grupo social) em patamares dignos. E tal responsabilidade não é apenas moral, mas também jurídica. ${ }^{214}$

Em particular, a decisão dogmática básica, a saber, quais as funções assumidas pela responsabilidade civil atual, não podem ser compreendidas somente por leis ordinárias, senão fundadas nos cânones constitucionais do direito individual, coletivo e social de segurança - art. $5^{\circ}$, caput e art. $6^{\circ}$, caput; no objetivo fundamental e direito-dever da solidariedade - art. $3^{\circ}$, inciso I; na existência humana digna - art. $1^{\circ}$, inciso III e art. 170, caput; na reparação de danos materiais e morais - art. 5º, inciso X, art. 225, parágrafo $3^{\circ}$, entre outros; e no dever de prevenção de danos atual e transgeracional - art. 225, caput. Ressaltando a prevenção de danos, pode-se, igualmente, destacar o princípio da inafastabilidade da jurisdição ou acesso à justiça - art. $5^{\circ}, \mathrm{XXXV}$, que acolheu a função preventiva da responsabilidade ao determinar que não se exclua de apreciação do Poder Judiciário lesão ou ameaça ao direito.

Uma vez fundada constitucionalmente as funções da responsabilidade civil, também a sua estruturação dogmática deve orientar-se, por óbvia conveniência, na base dos mesmos fundamentos constitucionais, pois a interpretação de seus pressupostos deve estar estabelecida conforme as funções que a Constituição permite atribuir à responsabilidade civil. A respeito, Rogério Donnini expressa que "nossa Lei Maior recepcionou o princípio sub studio de maneira adequada e ampla, motivo pelo qual o dever de prevenção a danos e sua reparação tem incidência no sistema constitucional e, como consequência lógica, em todos os subsistemas dele decorrentes". 215

A responsabilidade civil há de encontrar, pois, seu fundamento nos princípios, objetivos, direitos, garantias e deveres constitucionais do Estado Democrático de Direito, que se converte assim no suporte valorativo dos pilares sobre os quais gravita todo o sistema teleológico da responsabilidade civil. Inegável, portanto, é reconhecer que a responsabilidade civil, além de reparar o dano, também cumpre uma função preventiva, o que é observado também por Manuel Carneiro da Frada:

214. SARLET, Ingo Wolfgang; FENSTERSEIFER, Tiago. Op.cit., p.136.

215. Prevenção de danos e a extensão do princípio neminem laedere. In: NERY, Rosa Maria de Andrade e DONNINI, Rogério (Organizadores). Responsabilidade Civil: estudos em homenagem ao Professor Rui Geraldo Camargo Viana. São Paulo: Editora Revista dos Tribunais, 2009, p.493-494. 
[...] é função do Direito - e a observação pode fazer-se também em relação a outros sistemas - estabilizar e tutelar, no seu âmbito específico, as expectativas e condicionantes da existência dos homens por forma a subtraí-los do arbítrio destruidor da imprevisibilidade. [...] A contingência é assim inarredável e, se o sistema jurídico não pode eliminá-la, possui por outro lado meios para a prevenir ou controlar. [...] A responsabilidade civil comunga desta ratio que informa as normas jurídicas. ${ }^{216}$

De observar-se, contudo, que a função preventiva da responsabilidade civil pode ser compreendida através de dois sentidos - o secundário e o primário, neste momento esclarecido no intuito de evitar miscelânea.

No sentido secundário, a função preventiva traz a ideia de que a indenização imposta em decorrência do dano atua como elemento dissuasório, ${ }^{217}$ ou seja, poderoso incentivo para que o mesmo não se verifique novamente, presumindo um agir cauteloso do possível causador do dano para escapar à aplicação da sanção reparatória. Essa função é decorrente da imposição da indenização, como um efeito secundário desta, sendo que o objetivo primordial é mantido na reparação. Essa prevenção decorrente de um impulso psicológico, em que o lesante reconhece a norma jurídica e se dispõe a evitar os efeitos desfavoráveis que sobre ele resultaria a sua aplicação, assemelha-se ao que a doutrina penal ${ }^{218}$ atribui como funções da pena - a prevenção geral, que por força da existência da norma atua sobre os cidadãos como um todo; e a prevenção especial, que age especificamente sobre a pessoa que já foi responsabilizada por uma indenização, influenciando as ações futuras da mesma. ${ }^{219}$

Ao visualizar a responsabilidade civil sob a ótica da função preventiva, Luis Díez-Picazo observa que "ao lado da prevenção como impulso psicológico aparece a

216. Contrato e deveres de proteção. Separata do volume XXXVIII do Suplemento ao Boletim da Faculdade de Direito da Universidade de Coimbra. Coimbra: Gráfica de Coimbra, 1994, p.119.

217. NORONHA, Fernando. Direito das obrigações. Vol. 1. 2a ed. São Paulo: Saraiva, 2007, p.441.

218. PUIG, Santiago Mir. Funcion de la pena y teoria del delito en el Estado Social y Democratico de Derecho. 2a edición revisada. Barcelona: Bosch, 1982, p.42: “[...] En efecto el endendimiento de la pena como medio de prevención, al servicio de la protección efectiva de los ciudadanos, supone atribuir un significado directivo (en este sentido, 'imperativo'), de regulación social, a la norma jurídico-penal, asignándole la función de crear expectativas sociales que motiven a la colectividad en contra de la comisión de delitos".

219. ALTERINI, Atilio Anibal. Contornos actuales de la responsabilidade civil. Buenos Aires: AbeledoPerrot, 1987, p.26-27: "La política de evitación de daños concierne también a los mecanismos de prevención general y de prevención especial." 
prevenção como atividade racional do homo economicus", ${ }^{220}$ especialmente ao considerar os custos de segurança como um parâmetro para a eficiência. Desta feita, para a vertente da análise econômica da responsabilidade civil, a função preventiva também possui manifestação secundária. Os estudos que tratam da relação entre Direito e Economia, sobretudo a partir das clássicas obras de Guido Calabresi ${ }^{221}$ e Richard A. Posner, ${ }^{222}$ acentuam que a finalidade fundamental da responsabilidade civil é prevenir acidentes, porque o temor à indenização é um incentivo para investimentos em custos de segurança eficientes.

Assim, a imposição de uma indenização às condutas que ocasionam danos terá como efeito a internalização dos custos, considerados externalidades negativas. Isto porque, o custo externo à atividade produtiva, ou seja, o dano, não pode ser imputado à sociedade em geral, atuando a responsabilidade civil como um mecanismo de correção e distribuição dos riscos, ${ }^{223}$ ao atribuir os custos sociais à atividade que causou o prejuízo ou obteve benefícios econômicos deste. Por sua vez, a internalização dos custos acarretará, como consequência, a majoração do preço do produto ou serviço oferecido ao consumidor, colocando o seu fornecedor em posição de desvantagem em relação aos demais concorrentes do mercado. Diante disso, a racionalidade econômica subjacente ao sistema de responsabilidade civil $^{224}$ impõe a avaliação dos custos de uma atividade potencialmente danosa pelo agente econômico e incentiva o investimento em custos de prevenção e precaução. Nesse caso, portanto, o efeito preventivo (deterrence) ocorre de forma

220. Fundamentos del derecho civil patrimonial V: la responsabilidade civil extracontratual. Pamplona: Civitas-Thomson Reuters, 2011, p.27.

221. The costs of accidents: a legal and economic analysis. New Haven : Yale Univ Press, 1970, passim.

222. El análisis económico del derecho. Trad. Eduardo L. Suárez. México: Fondo de Cultura Económica, 1998, p.156.

223. A lógica da distribuição dos riscos de uma atividade é explicitada por CARNAÚBA, Daniel Amaral. Distribuição de riscos nas relações de consumo: uma análise econômica. In: LOPEZ, Teresa Ancona; LEMOS, Patrícia Faga Iglecias; RODRIGUES JÚNIOR, Otávio Luiz. Sociedade de risco e direito privado: desafios normativos, consumeristas e ambientais. São Paulo: Atlas, 2013, p.29: "Ao analisar a responsabilidade civil, o jurista típico enxerga nesta um meio de eliminação dos danos causados por uma determinada atividade. Ora, tal raciocínio peca pela unilateralidade, visto que reduz o mecanismo a apenas um de seus vetores. Do ponto de vista global da operação, a responsabilidade civil não elimina um prejuízo - até porque tal eliminação dependeria do desfazimento da própria realidade. Por meio da reparação civil, o prejuízo, que de início recaiu sobre a vítima, será apenas realocado para o indivíduo legalmente obrigado a indenizá-la. O prejuízo supostamente reparado continua a existir e será sentido não mais pela vítima, assim pelo indivíduo considerado 'responsável' nos termos do Direito. A responsabilidade civil é assim um mecanismo legal de distribuição dos riscos de uma atividade”. 
consequente. $^{225}$

Igualmente a já mencionada função punitiva da responsabilidade civil colabora para o alcance de um efeito preventivo, ainda que indireto. Isto porque, a aplicação de uma indenização cujo valor ultrapasse a equivalência do dano causado, a par de caracterizar uma punição, também carrega um claro objetivo preventivo, através do que Paolo Gallo ${ }^{226}$ denomina "função moralizadora dos danos punitivos". Nessa concepção, em caso de danos difusos, capazes de afetar um grande número de pessoas, mesmo em locais bem distantes daquele aonde se encontra o agente causador do dano, ou ainda, transtemporais, a ideia de simples reparação do dano não é hábil para incentivar a prevenção. Em contrapartida, a exigência superior de tutela da pessoa e de valores considerados relevantes, que não podem ser reduzidos a meros dados contábeis, justifica a aplicação dos "danos punitivos" com cariz "moralizador". O significado dessa perspectiva reside na mensagem ao causador do dano de que contra certos valores não se admite violação, ainda que de um ponto de vista puramente econômico seja mais apropriado agir diversamente.

224. Wanderley FERNANDES observa que: “embora a racionalidade econômica seja pautada pelo lucro, sendo o risco um elemento a ser considerado pelo agente econômico, a racionalidade jurídica acaba por valer-se do conceito econômico de risco para alocar ao titular da atividade econômica o dever de reparação dos danos causados a terceiros". Cláusulas de exoneração e de limitação de responsabilidade. São Paulo: Saraiva, 2013, p. 84.

225. A análise econômica da responsabilidade civil evidencia que o efeito preventivo pode estar presente tanto na responsabilidade objetiva, quanto na subjetiva, conforme demonstra MENDONÇA, Diogo Naves. O dano e a sua quantificação: perspectivas de direito e economia. Dissertação de Mestrado. Faculdade de Direito. Universidade de São Paulo. São Paulo. 2012. p.119-120: "Tratando-se de responsabilidade objetiva, se a indenização equivale exatamente ao prejuízo, as partes têm incentivos corretos para adotar medidas de precaução, sendo induzidas a fazê-lo se e apenas se os custos forem inferiores à respectiva redução nos danos esperados. Em sentido contrário, fixando-se indenização inferior ou superior ao prejuízo, as medidas de precaução tenderão a ser insuficientes ou excessivas. Além disso, a igualdade entre indenização e prejuízo concede corretos incentivos a que os potenciais lesantes submetidos à responsabilidade objetiva engajem-se em medida desejável nas atividades de risco. Afinal, só será realizada aquela atividade caso os benefícios obtidos com ela superem seus custos, incluindo-se os resultantes dos prejuízos causados a terceiros. Tratando-se de produtos postos no mercado, por exemplo, os prejuízos comporão de modo exato o custo total do produto, afetando a demanda e, por consequência, o patamar de atividade. No entanto, caso a indenização seja fixada em um montante inferior ou superior ao prejuízo efetivo, os níveis de atividade tenderão a ser socialmente excessivos ou indesejavelmente baixos. [...] Já diante de uma regra de responsabilidade subjetiva, caso a indenização corresponda fielmente ao prejuízo, o potencial causador de danos será induzido a cumprir o parâmetro de diligência exigido, tomando as medidas adequadas de precaução. Se a indenização superar o prejuízo, o lesante em potencial terá incentivos ainda mais fortes para encontrar o parâmetro de diligência. No entanto, caso a indenização seja inferior ao prejuízo causado, o parâmetro de cuidado poderá não ser cumprido, especificamente na hipótese em que os custos de precaução exigidos pelo parâmetro de cuidado forem superiores à indenização fixada, o que resultará em uma dissuasão inferior ao ótimo social ("underdeterrence")."

226. Pene private e responsabilità civile. Milano: Dott. A. Giuffrè Editore, 1996, p.167-169. 
O segundo sentido da função preventiva - o primário, por sua vez, sustenta que a responsabilidade civil pode atuar antecipadamente a ocorrência do dano para gestão e controle dos riscos, em um sentido preventivo prospectivo, voltado para o futuro. Essa abordagem se opõe radicalmente ao mecanismo tradicional de responsabilidade civil apoiado em uma conotação curativa e encontra fundamento nos princípios da precaução e da prevenção, que não poderiam restar indiferentes à responsabilidade civil, consoante ressalta Daphné Tapinos:

De fato, a proliferação e a extensão de alguns danos, em particular na área do meio ambiente e saúde, situaram o futuro da responsabilidade civil e a questão da adaptação dessa instituição aos fatos no centro das discussões. Não somente os riscos associados ao progresso constante da tecnologia contemporânea são mais numerosos, eles são atualmente menos tolerados pela sociedade. Sintoma da crescente preocupação com segurança, os princípios da prevenção e da precaução parecem cristalizar a crise, amplamente denunciada, que enfrenta atualmente o direito da responsabilidade civil. ${ }^{227}$

Desta feita, cabe observar que o princípio tão caro à responsabilidade civil, alterum non laedere, pode perfeitamente ser compreendido como um atuar anterior à ocorrência do prejuízo, pois ordena precisamente não causar dano a outrem, incentivando tanto a prevenção ex ante, como também a reparação post factum. ${ }^{228}$

Privilegia-se, dessa forma, a coexistência social ordenada, ao abrigo de violações nas condições existenciais, sejam individuais ou difusas, atuais ou transgeracionais, sem descurar do aspecto protetivo que acompanha a responsabilidade

227. Prevention, precaution et responsabilité civile: risque avéré, risque suspecté et transformation du paradigme de la responsabilité civile. Paris: L'Harmattan, 2008, p.20-21. Em língua original: "Les principes de prévention et de précaution répondent à une logique préventive d'anticipation des dommages que résume la maxime bien connue 'mieux vaut prévenir que guérir'. Ils s'opposent donc au mécanisme traditionnel de la responsabilité civile fondée sur une logique curative. En effet, l'objet de cette dernière est d'énoncer les 'règles qui obligent l'auteur d'un dommage causé à autri à réparer ce préjudice en offrant à la victime une compensation'. Dans sons sens classique, la responsabilité civile intervient ainsi en aval, après la réalisation d'un dommage, qu'elle a pour objet de réparer. Pourtant, le droit de la responsabilité civile ne pouvait rester insensible à la reconnaissance juridique des principes de prévention et de précaution. [...] Symptôme du souci croissant de sécurité, les principes de prévention et de précaution semblent cristalliser la crise, partout dénoncée, que traverse actuellement le droit de la responsabilité civile."

228. Nesse sentido, consulte-se: HERRERA, Edgardo López. La función preventiva de la responsabilidad civil y su relación con las otras funciones. Revista de derecho de daños 2008-2: prevención del dano. Dirigido por Jorge Mosset Iturraspe y Ricardo Luis Lorenzetti. Santa Fe: Rubinzal-Culzoni, 2008, p.201. 
civil, quando exprime um dever de garantia ${ }^{229}$ em favor de todos os membros da sociedade ao contrapor liberdades e segurança. Ao considerar-se que o Princípio da Reparação Integral e o retorno ao status quo ante em sua totalidade é ficção teórica, melhor adaptável aos danos patrimoniais, e de intrincada aplicação tanto aos danos difusos e coletivos quanto aos danos causados aos direitos da personalidade, o realce à função preventiva prospectiva da responsabilidade civil, que inclui o risco, a potencialidade do dano e a tutela preventiva como discussão prioritária, é tarefa que o ordenamento jurídico não apenas admite como incentiva. Em consequência, "a responsabilidade civil passa a se preocupar com as questões que estão por vir, todavia sem olvidar da necessidade de reparação dos danos já ocasionados". 230

A partir da compreensão da responsabilidade civil como instituto voltado à proteção de bens e interesses atribuídos pelo Direito, não se justifica axiomaticamente a sua restrição ao escopo reparatório, mas um diálogo entre as variadas funções que teleologicamente encontram fundamento na Constituição Federal, para a promoção de valores voltados não apenas à vítima do dano, mas à proteção do gênero humano no contexto social. Somente a junção desses fatores a benefício da sociedade é capaz de dar concretude à ideia de "direito justo", na elaboração de Karl Larenz:

En resumen: no hay un único principio de responsabilidad por daños, sino varios, y cada uno de ellos tiene su proprio campo de aplicación. Es común a todos la idea de una justa compensación del daño o de un justo reparto de determinados riegos de daños. En esa medida todos ellos son principios del Derecho justo. ${ }^{231}$

Sendo esse o panorama atual, resta demonstrar a seguir os princípios da precaução e da prevenção, que justificaram e expandiram o denso território normativo, dogmático e metodológico da Responsabilidade Civil Preventiva, com o objetivo de reconhecer nos mesmos uma norma fundante e uma matriz estratégica que ordene a

229. STARCK, Boris. Essai d'une théorie générale de la responsabilité civile considérée en sa double fonction de garantie et de peine privée. Paris: L. Rodstein, 1947, p.43: "Etudier la responsabilité sous l'angle d'un conflit de droits opposant l'auteur du dommage et la victime, à l'effet de savoir dans quelle mesure l'ordre juridique positif garantit aux hommes leurs libertés ou leur securité, tel est l'objet propre de la théorie de la garantie.

230. LEITE, José Rubens Morato; MELO, Melissa Ely. As funções preventivas e precaucionais da responsabilidade civil por danos ambientais. Revista Sequência, no 55, p.195-218, dez. 2007, p.210.

231. Derecho justo: fundamentos de etica juridica. Traducción y presentación Luis Díez-Picazo. Madrid: Editorial Civitas, 1991, 125. 
interpretação e a reconstrução teórica do instituto. ${ }^{232}$

232. É necessário empreender uma tarefa de reconstrução teórica da responsabilidade civil, que, na sugestão de Ricardo Luis LORENZETTI, deve partir das responsabilidades especiais, constatando nestas a heterogeneidade, e a partir desses dados, construir uma nova teoria geral, que compreenda os diversos subsistemas de responsabilização, a exemplo da temática ambiental, cujos princípios adotam um caráter reestruturante do sistema. Teoria da decisão judicial: fundamentos de direito. Trad. Bruno Miragem. Notas Cláudia Lima Marques. São Paulo: Editora Revista dos Tribunais, 2010, p.49. 


\section{A ARQUITETURA DA RESPONSABILIDADE CIVIL PREVENTIVA}

\section{CAPÍTULO 1. PRINCÍPIOS JURÍDICOS ESTRUTURANTES DA RESPONSABILIDADE CIVIL PREVENTIVA}

Estamos apenas no começo da ciência, e muito distante do tempo em que se acreditava possivel descrever todo o universo em termos de algumas poucas leis fundamentais. Encontramos o complexo e o irreversível no domínio microscópico (tal como associado às partículas elementares), no domínio macroscópico que nos cerca e no domínio da astrofísica. Cabe às futuras gerações construir uma nova ciência que incorpore todos esses aspectos, porque, por enquanto, a ciência continua em sua infância. ${ }^{233}$ (Ilya Prigogine)

\subsection{PRINCÍPIOS DA PRECAUÇÃO E DA PREVENÇÃO E A METODOLOGIA DE INTERPRETAÇÃO DA RESPONSABILIDADE CIVIL PREVENTIVA: A HERMENÊUTICA DA SUSPEIÇÃO}

O presente capítulo trata do tema relativo aos princípios estruturantes da Responsabilidade Civil Preventiva - princípio da precaução e princípio da prevenção.

Inicialmente, importa destacar, consoante exposto em tópico anterior, que quando a responsabilidade civil diversifica as suas funções, para absorver também a função preventiva prospectiva, ela o faz mediante a formação de um núcleo de significado estabelecido pelos princípios da precaução e da prevenção. Isso possibilita a análise crítica da autoridade das regras postas, que se submetem a reavaliação à luz de suas consequências para os valores envolvidos no caso concreto.

De início, observa-se não haver um consenso acerca do significado de princípio, conceito polissêmico decorrente da diversidade de posições doutrinárias 
existentes. $^{234} \mathrm{~A}$ importância do seu estudo reside em sua essência normativa e conteúdo axiológico, que explica, justifica e ordena os específicos campos de aplicação, expressando sentidos de dever-ser, podendo estar positivados ou não. ${ }^{235}$

Assim como as regras, os princípios são espécies de normas jurídicas que expressam um conteúdo deôntico, e se distinguem a partir do preceito normativo, pois a regra possui determinações referentes a um suporte fático definido no texto legal, enquanto os princípios não possuem um preceito e nem um âmbito de aplicação pré-definido. ${ }^{236}$ Essa diferenciação denota ao princípio uma maior generalidade, o que o faz ser compreendido, na difundida lição de Robert Alexy, como mandamentos de otimização ${ }^{237}$ que impõem na maior medida possível a sua realização.

Além disso, constatando o "avanço do Direito como norma ao Direito com princípios", Rodolfo Luis Vigo destaca que a proposta dos princípios implica:

a) que a validade jurídica já não pode ser reduzida a exigências formais, mas requer considerações substanciais éticas ou axiológicas;

b) que os meros tests de origem ou pedigree não bastam para identificar o Direito vigente;

c) que os órgãos com capacidade jurígena encontram limites preexistentes;

d) que é preciso problematizar o caráter operativo do Direito, pois já não basta a lógica formal mas se deve "pesar" o Direito disponível;

234. Um panorama sobre as contradições existentes na distinção entre princípios e regras, com análise de Ronald Dworkin, Robert Alexy, Humberto Ávila, Ana Paula Barcellos e Friedrich Müller, pode ser consultado em SILVA, Virgílio Afonso da. Princípios e regras: mitos e equívocos acerca de uma distinção. Revista Latino-Americana de Estudos Constitucionais 1 (2003): 607-630.

235. A Constituição Federal de 1988 reconhece a existência de princípios "implícitos", ou "não expressos", em seu art. ${ }^{\circ}, \S 2^{\circ}$ : Os direitos e garantias expressos nesta Constituição não excluem outros decorrentes do regime e dos princípios por ela adotados, ou dos tratados internacionais em que a República Federativa do Brasil seja parte.

236. Para um estudo mais detido que escaparia aos propósitos desta pesquisa, é importante consignar que inúmeros critérios podem ser apontados para a distinção entre regras e princípios, consoante enumeração de Fernando Rodrigues MARTINS, considerando o plano da interpretação da norma, o modo de aplicação, a interação normativa, a densidade axiológica, a conexão histórico-temporal e o plano da validade. Princípio da Justiça Contratual. São Paulo: Saraiva, 2011, p.273-274.

237. ALEXY, Robert. Teoria de los derechos fundamentales. Trad. Carlos Bernal Pulido. Madrid: Centro de Estudios Politicos y Constitucionales, 2007, p.83. 
e) que se deve questionar a rígida separação entre descrição e prescrição. ${ }^{238}$

Por conterem uma estrutura aberta, os princípios guardam um conteúdo normativo-material em composição com a moral coletiva do corpo social, que participa da composição dos limites de sua racionalidade, em uma relação dialógica entre hermenêutica e concretude. Disso decorre a necessidade de manejar o estudo dos princípios de forma transdisciplinar, com o auxílio da sociologia, filosofia, economia e outras ciências, no intuito de verificar as razões pelas quais eles são absorvidos normativamente.

Esse foi o propósito dos dois primeiros capítulos que compõem a Parte 1 do presente estudo, qual seja, indicar que as bruscas e aceleradas transformações percebidas nos aspectos social, econômico, tecnológico e científico no alvorecer do século passado resultaram na configuração de uma nova sociedade, produtora de uma dimensão inédita de riscos, capazes de denunciar a fragilidade do sistema jurídico até então vigente para lidar com as suas consequências.

A partir da necessidade do Direito traduzir respostas satisfatórias às novas exigências sociais, passa o mesmo a absorver novas funções, aptas a indicar o caminho a seguir, o que, no tocante à responsabilidade civil, resulta no reconhecimento de que a mesma também incorpora uma função preventiva prospectiva, cuja estruturação reside nos princípios da precaução e da prevenção. Em consequência, referidos princípios conferem uma dimensão emancipatória que autoriza o reconhecimento da Responsabilidade Civil Preventiva.

Para tanto, fez-se necessária a superação do positivismo dominante do século XX, transição fundamental para uma importante ressignificação metodológica em matéria de interpretação jurídica, que Francisco Amaral identifica como a passagem do "paradigma da aplicação" para o "paradigma judicativo-decisório". ${ }^{239}$ Nessa visão, abandona-se o procedimento lógico-dedutivo e o silogismo jurídico realizado a partir da norma geral e abstrata, típico de um modelo de interpretação normativista, cujas origens

238. Interpretação jurídica: do modelo juspositivista-legalista do século XIX às novas perspectivas. 2. ed. rev. São Paulo: Editora Revista dos Tribunais, 2010, p.240.

239. O Código Civil brasileiro e o problema metodológico de sua realização. Do paradigma da aplicação ao paradigma judicativo-decisório. In: CASTILHO, Ricardo; TARTUCE, Flávio (Coord.). Direito Civil: direito existencial e direito patrimonial. São Paulo: Método, 2006, p.21. 
remontam à Escola da Exegese. ${ }^{240}$ Em substituição, busca-se um modelo hermenêutico de conteúdo axiológico, jurisprudencialista, mais consentâneo com a Jurisprudência das Valorações. ${ }^{241}$ Com efeito, ao fazer referência à responsabilidade civil e ao papel do juiz, Renan Lotufo recorda que "o Código Civil de 2002 confia nos juízes como integradores das leis, não como meros locutores do texto escrito". ${ }^{242}$ Nessa tarefa de integração, os princípios tendem a ter maior proeminência do que estruturas e formas, desmistificando a natureza meramente técnico-instrumental do Direito Civil.

Aqui reside a importância dos princípios da precaução e da prevenção para estruturação sistemática da Responsabilidade Civil Preventiva. Em virtude dos princípios exercerem uma função normogenética e sistêmica, ${ }^{243}$ as regras formuladas devem guardar correspondência com os seus preceitos, sob pena de comprometimento de sua validade material. Isto é, uma regra no campo da responsabilidade civil que atenda à função preventiva prospectiva, nos termos tratados no capítulo anterior, será materialmente válida se o seu conteúdo normativo coadunar com os valores instituídos pelos princípios da precaução e da prevenção.

Nessa mesma ótica, observa Teresa Ancona Lopez que "os sistemas jurídicos adquirem a identidade de seus princípios, em que, juntando e 'costurando' as

240. Segundo GILISSEN, John. Introdução histórica ao Direito. Trad. A.M.Hespanha e L.M.Macaísta Malheiros. 2a ed. Lisboa: Fundação Calouste Gulbenkian, 1995, p.515: “A partir da promulgação do Code Civil, os juristas começaram a estudá-lo dedicando-se mais especialmente à análise do seu texto. Consideravam-no como algo de absolutamente novo, que era necessário explicar sem ter o passado em conta. Atribuíram à análise textual uma importância capital, explicando um artigo a partir de outro, combinando-os entre si (...) Isolavam assim o Code Civil - e também os outros códigos - do meio social no qual ele tinha nascido e no qual ele devia ser aplicado".

241. LOSANO, Mario G. Sistema e estrutura no direito. Vol. 2. O século XX. Trad. Luca Lamberti. São Paulo: Martins Fontes, 2010, p.248: "Por isso, prosseguindo e integrando a jurisprudência dos interesses, a jurisprudência dos valores pretende indicar qual é a origem dos valores que guiam a decisão do juiz quando a norma positiva não lhe oferece critérios suficientes para avaliar o caso concreto. Consequentemente, a jurisprudência dos valores completa - mas não substitui - a jurisprudência dos interesses: quando a analogia já não é de ajuda, quando não é possível verificar quais interesses moveram o legislador, quando, em suma, as normas são imprecisas ou lacunosas, então intervém a jurisprudência dos valores para indicar quais valores podem ser aplicados compativelmente com o ordenamento jurídico." Essa corrente metodológica é trabalhada por jusfilósofos como Esser, Larenz, Wilburg e Canaris.

242. A responsabilidade civil e o papel do juiz no Código Civil de 2002. In: NERY, Rosa Maria de Andrade e DONNINI, Rogério (Organizadores). Responsabilidade Civil: estudos em homenagem ao Professor Rui Geraldo Camargo Viana. São Paulo: Editora Revista dos Tribunais, 2009, p.462.

243. BERBERI, Marco Antônio Lima. Os princípios na teoria do direito. Rio de Janeiro: Renovar, 2003, p. 179 . 
regras, os preceitos e as normas formam um sistema uno". ${ }^{244}$ Portanto, a sistematização da Responsabilidade Civil Preventiva é o resultado da atuação dos princípios da precaução e da prevenção.

Contudo, a possibilidade que esse novo paradigma tem de efetivamente ocupar o lugar até recentemente ocupado de modo hegemônico pelo formalismo e pelo normativismo conduz o operador do Direito à necessária construção de uma hermenêutica crítica e especulativa, ${ }^{245}$ na tentativa de superar a crise pela qual perpassa a responsabilidade civil, capacitando esse instituto com instrumentos jurídicos que resguardem inteiramente as inquietações e necessidades do estágio atual do desenvolvimento. Demarque-se que "uma posição 'crítica' há de ser vista, portanto, não só como uma avaliação crítica de nossa condição presente, mas crítica em trabalhar na direção a uma nova existência". ${ }^{246}$

O desconforto trazido pela racionalidade tradicional e retrospectiva da responsabilidade civil, em lidar com contingências, riscos e danos em tempos pósmodernos, aponta para o reconhecimento de sua inadequação, diante da complexidade das novas formas de produção e ciência, e abre espaço para o surgimento de padrões alternativos de fundamentação, no qual sobressai a aplicação dos princípios da precaução e da prevenção.

Com efeito, referidos princípios são capazes de conferir novo significado, finalidade e implicações ao tradicional instituto da responsabilidade civil, rompendo com a unicidade do padrão retrospectivo instituído, constituindo-se em um instrumento de normas que atendam a um fundamental interesse da experiência social - a gestão dos riscos e prevenção de sua potencialidade danosa.

Com inspiração nos mesmos princípios da precaução e da prevenção, é possível realizar o exercício de um pensamento crítico nos domínios da responsabilidade civil, ao questionar "a normatividade que está ordenada/legitimada em uma dada formação

\footnotetext{
244. Princípio da precaução e evolução da responsabilidade civil. São Paulo: Quartier Latin, 2010, p.90.

245. FARIA, José Eduardo. Direito e conjuntura. 2. ed. São Paulo: Saraiva, 2010, p.121.

246. WOLKMER, Antonio Carlos. Introdução ao pensamento jurídico crítico. 5. ed. rev. São Paulo: Saraiva, 2006, p.5.
} 
social e admitir a possibilidade de outras formas de práticas diferenciadas no jurídico", 247 e por consequência, apontar outro referencial epistemológico que atenda à sociedade de riscos.

A partir da admissão de que a interpretação é um processo criativo e pragmático de direito, os princípios da precaução e da prevenção convidam ao emprego de um conhecimento prudente, pois a complexidade da evolução tecnocientífica já tratada nos capítulos anteriores dissociou a capacidade de ação (controle das causas) e a capacidade de previsão (controle das consequências), muitas vezes abstraindo do domínio humano a administração segura entre causa e efeito. ${ }^{248}$

Não se trata de um pensamento redutor, e sim de uma opção por uma atitude epistemológica que, por exigência prática, considera as indesejáveis implicações concretoparticulares da realidade social e exigem prudência. Recorde-se, no ponto, António Castanheira Neves, ao indicar que na esteira do funcionalismo, o direito passa a ser "um instrumento - um finalístico instrumento e um meio ao serviço de teleologias que de fora o convocam e condicionantemente o submetem". ${ }^{249}$ Nesse desiderato, os princípios da precaução e da prevenção induzem e incentivam o pleno desenvolvimento da Responsabilidade Civil Preventiva como um instrumento a serviço da almejada segurança em tempos de complexidades não inteiramente identificadas.

Em oposição ao esquema causal e retrospectivo da responsabilidade civil reparatória, que em determinadas situações de danos graves e irreversíveis pouco tem a oferecer, a absorção dos princípios da precaução e da prevenção contribuem para uma performance e eficácia mais consentâneas com as expectativas da atualidade, e novos campos são abertos para a atuação dos operadores do Direito. Para tanto, a postura hermenêutica e até mesmo arrojada, a ser adotada, não mais trabalha com a certeza do dano, e sim com a suspeição de sua ocorrência, com foco na dimensão das consequências. Não se podem omitir, nesse sentido, as recomendações de Boaventura Sousa Santos, quanto à adoção da hermenêutica da suspeição:

247. WOLKMER, Antônio Carlos. op.cit., p.85.

248. SANTOS, Boaventura de Sousa. Para um novo senso comum: a ciência, o direito e a política na transição paradigmática. Vol. 1. A crítica da razão indolente: contra o desperdício da experiência. 4. ed. São Paulo: Cortez, 2002, p.80.

249. O direito hoje e com que sentido? $2^{\mathrm{a}}$ ed. Lisboa: Instituto Piaget, 2011, p.30. 
O princípio da prudência faz-nos uma dupla exigência. Por um lado, exige que, perante os limites da nossa capacidade de previsão, em comparação com o poder e a complexidade da práxis tecnológica, privilegiemos perscrutar as consequências negativas desta em detrimento das suas consequências positivas. Não deve ver-se nisto uma atitude pessimista e muito menos uma atitude reacionária. Uma das virtualidades do utopismo tecnológico é que, hoje, sabemos melhor aquilo que não queremos do que aquilo que queremos. Se a nossa capacidade de previsão é menos limitada a respeito das consequências negativas do que a respeito das consequências positivas, é de bom senso concentrar o conhecimento emancipatório nas consequências negativas. Isto implica assumir perante ela - e esta é a segunda exigência - uma certa"hermenêutica da suspeição", como Ricoeur lhe chamaria: as consequências negativas duvidosas, mas possíveis, devem ser tidas como certas. ${ }^{250}$

A responsabilidade civil reparatória e retrospectiva, ao exigir o cumprimento de uma estrutura conceitual e lógica, pode tornar-se distante da teleologia imposta em determinados setores na vivência atual, a ponto de comprometer o seu conteúdo normativo material, com os seus problemas e historicidade concretos apontando para uma crise no sentido ${ }^{251}$ da responsabilidade civil.

Diante dessa constatação, é forçoso concluir que a sistematização de um modelo de Responsabilidade Civil Preventiva está consolidada, por exigência sociológica (complexidade estrutural da sociedade atual), axiológica (mutação de referenciais valorativos com ênfase em prevenção), crítico-cultural (desconstrução e superação de uma racionalidade normativa carente de fundamentação) e também funcional (capacidade de resposta e superação de conflitos).

Os princípios $^{252}$ da precaução e da prevenção, ao exprimirem sentido

250. Para um novo senso comum: a ciência, o direito e a política na transição paradigmática. Vol. 1. A crítica da razão indolente: contra o desperdício da experiência. 4. ed. São Paulo: Cortez, 2002, p.80.

251. CASTANHEIRA NEVES, António. O direito hoje e com que sentido? $2^{\mathrm{a}}$ ed. Lisboa: Instituto Piaget, 2011, p.17: "Não se trata, assim, tão-só do problemático que a porventura assimetria, a dessincronização, a inadequação sistemática entre o direito e o seu 'meio' contextual (a sociedade que o solicita) hoje provoquem, ou sequer da problemática que já filosoficamente sempre se justificaria - o problema ontológico da compreensão do seu ser, o problema axiológico da fundamentação da sua validade. Trata-se, mais profundamente, do problema radical do seu sentido e subsistência para nós nesta nossa situação histórica (histórico-social e histórico-cultural) e em que nós a nós próprios afinal também radicalmente nos interrogamos."

252. ÁVILA, Humberto. Teoria dos princípios: da definição à aplicação dos princípios jurídicos. São Paulo: Malheiros, 2011, p.80: “Os princípios instituem o dever de adotar comportamentos necessários à realização de um estado de coisas, ou, inversamente, instituem o dever de efetivação de um estado de coisas pela adoção de comportamentos a ele necessários. Essa perspectiva de análise evidencia que os princípios implicam em comportamentos, ainda que por via indireta ou regressiva". 
deôntico, instituem o dever do operador do Direito adotar uma hermenêutica necessária à promoção de um fim devido. São normas abertas que veiculam o output do meio social no conteúdo material de sua previsão. Por sua vez, é o valor ético-social da segurança, dominante objetiva e uniformemente na sociedade contemporânea, que no campo de atuação da responsabilidade civil irá fundamentar e orientar o intérprete na elucidação das medidas necessárias a atingir tal finalidade, através de uma atuação dinâmica que necessita ser avaliada e individualizada razoavelmente.

Todos esses fatores serão considerados a seguir, no estudo das especificidades dos princípios da precaução e da prevenção no ordenamento jurídico atual.

\subsection{GÊNESE DO PRINCÍPIO DA PRECAUÇÃO E ÂMBITO DE APLICAÇÃO}

A evolução da ciência, tecnologia e indústria é um processo tão inevitável quanto essencial à qualidade de vida humana. Essa constatação é evidente ao senso comum, basta recordar que em um período não muito longínquo, a partir do século XIX, o alargamento dos limites contingentes ao conhecimento científico foi responsável por transformações às quais o homem da pós-modernidade não poderia prescindir, tanto em suas relações sociais, como na própria condição existencial, imprimindo ao nível filosófico, político, econômico, social e cultural a abertura de caminhos irreversíveis.

A enumeração dessas verdadeiras metamorfoses é infinita: pequenas oficinas transmudaram-se em grandes indústrias; o desenvolvimento do maquinismo a vapor revolucionou os meios de transporte, sucedido pelo motor de explosão, o que permitiu a criação dos automóveis e em seguida, de aeronaves; o incremento dos meios de comunicação facilitou a integração e divulgação de informações por toda a humanidade, a partir do telégrafo, evoluindo ao telefone, até alcançarmos a transferência de dados pela rede mundial de computadores, cada vez mais suportada por fibras ópticas em substituição aos fios de cobre; a eletricidade provocou um giro nos processos de fabricação, para oportunizar, em seguida, o conforto no interior de residências; o advento da lâmpada incandescente substituiu o lampião a gás e a lanterna de querosene na iluminação das cidades e casas, e mais recentemente, novos artefatos de maior eficiência energética são 
utilizados em substituição.

Em matéria de avanços importantes para a medicina moderna, valem mencionar o surgimento de vacinas, exames eletromagnéticos, anestesia, técnicas de cultura de células, antibióticos, avanços na anatomia e no conhecimento do sistema circulatório, bacteriologia, além do mapeamento do genoma humano após a descoberta do DNA, entre as conquistas mais decisivas das ciências médicas hoje praticadas. ${ }^{253}$

Entretanto, nem sempre as consequências dessa inevitável evolução podem ser avaliadas como positivas, pois enfocadas sob ponto de vista oposto, é possível constatar o acúmulo de danos ao ser humano e ao planeta, derivados de fatores como a emissão de substâncias tóxicas e radioativas, redução da diversidade biológica, efeitos nefastos de medicamentos a uma geração de pessoas, surgimento de doenças derivadas do uso de hormônios em produtos alimentícios, além de tantas incertezas decorrentes desse mesmo progresso, a exemplo dos efeitos sobre a saúde humana das ondas eletromagnéticas da telefonia móvel bem como ingestão de organismos geneticamente modificados (OGM).

Em decorrência, como efeito típico da Sociedade de Riscos já retratada no primeiro capítulo dessa pesquisa, manifestam-se temores e dúvidas a respeito dos graves danos possíveis. Nesse cenário, a crença no progresso trazido pela ciência e a garantia de segurança são fortemente abaladas, e tem início o discurso do risco em meio ao paradoxo estabelecido pela incerteza. Eric Hobsbawm afirmou que "nenhum período da história foi mais penetrado pelas ciências naturais nem mais dependente delas do que o século XX. No entanto, nenhum período, desde a retratação de Galileu, se sentiu menos à vontade com elas. Este é o paradoxo com o qual o historiador do século deve lutar." 254

Em meio à falta de consenso em alguns setores fundamentais ao interesse público, como a saúde e o ambiente, a respeito da avaliação científica sobre as consequências de suas próprias atividades, resta como objetivo a ser alcançado pelos operadores jurídicos encontrar um ponto de equilíbrio entre a natural e espontânea

253. FRIEDMAN, Meyer; FRIEDLAND, Geral W. As dez maiores descobertas da medicina. Trad. José Rubens Siqueira. São Paulo: Companhia de Bolso, 2006.

254. Age of extremes: the short twentieth century 1914-1991. London: Abacus, 1995, p.522. Tradução livre. Em língua original: "No period in history has been more penetrated by and more dependent on the natural sciences than the twentieth century. Yet no period, since Galileo's recantation, has been less at ease with it. This is the paradox with which the historian of the century must grapple." 
aspiração do homem ao desenvolvimento das ciências em geral, e a manutenção da segurança, que por sua vez é obrigação veiculada pelo Direito. Desse balanceamento, surge a proposta do princípio da precaução, que se transmuta de regra de comportamento a norma jurídica, alargando o seu campo de aplicação a uma multiplicidade de situações.

O princípio da precaução nasce, portanto, como exigência de antecipação de riscos e consequências possivelmente danosas, posto que a dissolução do mito da infalibilidade da ciência fortaleceu um sentido de prudência que considera o conhecimento científico e tecnológico não mais absoluto e definitivo. Representa, pois, uma resposta normativa em face da incerteza.

Considera-se que o marco referencial do princípio da precaução surgiu na Alemanha, ${ }^{255}$ com o intuito de conduzir ações para o controle da poluição atmosférica. Os alemães, em um período de grande movimentação social de cunho ambientalista, desenvolveram esse conceito concebido como um princípio de política ambiental, em resposta à constatação de que as atividades industriais e comerciais indiscriminadas produziram uma série de danos ambientais de dimensões continentais que ameaçavam não apenas a Alemanha, mas a Europa em geral, como a poluição do Mar do Norte, o aquecimento global e o fenômeno da chuva ácida que devastava sua floresta de coníferas.

Emerge, assim, a ideia do Vorsorgeprinzip. Do exame da palavra em sua língua originária, depreende-se que o termo Vorsorge expressa preocupação com o cuidar do futuro (prefixo vor - indica antecedência, conjugado a Sorge - significa preocupação, apreensão, cuidado, solicitude). O verbo Vorsorgen significa, portanto, preocupar e cuidar de algo com antecedência. Isso denota um avanço em relação a uma noção simplificada de atuação preventiva, pois inclui um aspecto temporal prospectivo, além da percepção de gestão responsável.

De forma gradual, o Vorsorgeprinzip começou a ser incorporado, inicialmente no Programa Ambiental de 1971 (Umweltprogramm) e após, no Relatório

255. Nesse sentido: PRIEUR, Michel. Le Principe de Précaution: "Les prolégomènes du concept de précaution doivent être recherchés dans la doctrine en Allemagne dans la fin des années 1970 avec le terme 'Vorsorgeprinzip' repris par la loi et par la jurisprudence des tribunaux administratifs allemands pour qui la précaution s'impose même dans des cas concrets ou le lien de causalité n'est pas encore établi”. Disponível em <http://www.legiscompare.fr/site-web/IMG/pdf/2-Prieur.pdf>. Acesso em: 20 set. 2013. 
Ambiental de 1976 (Umweltbericht) do governo alemão, aqui enunciado como um princípio de aplicação geral, indicativo de que a política ambiental não está totalmente realizada apenas afastando perigos iminentes ou eliminando danos já ocorridos. A política ambiental de precaução vai além da mera proteção de recursos naturais e requer que ela seja desempenhada com cuidado. Esse princípio foi incorporado, também, no $§ 1^{\circ}$ da Lei de Controle de Emissões (Bundes-Immissionsschutzgesetz - BimSchG) e $\S 1^{\circ}$ da Lei de Recursos Hídricos (Wasserhaushaltsgesetz - WHG). O ponto central do conceito alemão em termos de precaução foi a ideia de que os governos devem adotar medidas para minimizar os riscos ambientais, antecipando e impedindo os possíveis danos.

De salientar-se que o princípio da precaução não exige a total inexistência de desgaste ao meio ambiente, mas sim, que a sua exploração ocorra da forma menos danosa que se possa alcançar. Em outras palavras, os recursos naturais e o espaço vital podem ser explorados pelo homem, porém, da forma cautelosa, procurando-se sempre assegurar que eles possam ser utilizados pelas próximas gerações.

O princípio da precaução surgiu a partir da evidência de que os métodos tradicionais de tomada de decisão ambiental anteriormente utilizado para evitar a ocorrência de danos sérios ou irreversíveis não eram capazes de cumprir tal finalidade. A abordagem permissiva à regulamentação ambiental baseava-se na ideia de que a ciência poderia prever limitadamente o resultado em termos de impacto ambiental de uma determinada atividade, e explorar a capacidade de assimilação dos ecossistemas às atividades humanas até esse limite. Assim, a ação para proteger o ambiente poderia ser justificada apenas quando houvesse uma evidência cientificamente demonstrável de que a ausência de medidas protetivas causaria efetivamente um dano considerável. Sob o ponto de vista econômico, como toda intervenção tem um custo, a racionalidade desse pensamento tende a reconhecer como injustificado o investimento caso, diante da incerteza científica, não haja razão para tanto.

A partir da inovação alemã, a expansão do princípio da precaução ocorreu rapidamente. No decorrer dos anos oitenta, referido princípio alcançou o cenário do direito internacional, pois havia um consenso geral de que o desenvolvimento das atividades humanas tinha alcançado uma dimensão tão larga que as suas consequências sobre o meio ambiente não ficavam limitadas a um espaço local. Essa visão é bem explorada por Ulrich 
Beck, ${ }^{256}$ conforme tratamos no primeiro capítulo desse estudo, ao demonstrar que os efeitos adversos da modernidade reflexiva evoluíram a dimensões transnacionais, com alcance até mesmo global.

Assim, a ampliação de consciência sobre riscos significativos, capazes de causar danos graves em larga escala, provocou a necessidade de empreender medidas de precaução que ultrapassam a simples prevenção, ou seja, medidas capazes de lidar com atividades que podem, ou não, apresentar efeitos negativos, e não apenas atividades cujos riscos já são conhecidos. A precaução tinha por norte transcender a prevenção.

A partir desse contexto, referências normativas ao princípio da precaução difundiram-se amplamente, incorporadas em convenções e declarações internacionais, bem como nos ordenamentos jurídico internos, em paulatina evolução.

Em 1987, a Conferência Internacional sobre a proteção do Mar do Norte referiu-se a uma "abordagem de precaução". Nos anos posteriores, diversas convenções bilaterais e multilaterais fizeram referência tanto a uma "abordagem de precaução" quanto a um "princípio de precaução". 257

Em 1992, o princípio da precaução obteve o seu reconhecimento jurídico internacional definitivo, através da acolhida no Direito Comunitário Europeu pelo Tratado de Maastricht, em seu art. 130-R (posteriormente, confirmado junto ao art. 174 do Tratado de Amsterdã) e na Conferência das Nações Unidas sobre Meio Ambiente e Desenvolvimento (ECO-92), restando consolidado no Princípio 15 da Declaração do Rio de Janeiro com o seguinte enunciado:

Princípio 15 - De modo a proteger o meio ambiente, o princípio da precaução deve ser amplamente observado pelos Estados, de acordo com suas capacidades. Quando houver ameaça de danos sérios ou irreversíveis, a ausência de absoluta certeza científica não deve ser utilizada como razão para postergar medidas eficazes e economicamente viáveis para prevenir a degradação ambiental.

256. BECK, Ulrich. Sociedade de Risco: rumo a uma outra modernidade. Trad. Sebastião Nascimento. São Paulo: Ed. 34, 2010, passim.

257. Para uma ampla consulta acerca da consagração progressiva do Princípio da Precaução nas convenções internacionais: SADELEER, Nicolas de. O Estatuto do Princípio da Precaução no Direito Internacional. In: VARELlA, Marcelo Dias; PLATIAU, Ana Flávia Barros (Org.). Princípio da precaução. Belo Horizonte: Del Rey, 2004, p.51 et seq. 
No aspecto social, os debates públicos e a popularização do princípio da precaução ocorreram quando eclodiram crises sanitárias de grande repercussão, como a encefalopatia espongiforme bovina (mal da vaca louca) e os conflitos em torno dos organismos geneticamente modificados (OGMs).

De observar-se que o alargamento da abrangência de proteção das normas internacionais para campos transfronteiriços não se restringiu ao meio ambiente, haja vista que a supremacia dos valores da pessoa humana e consequente proteção dos direitos humanos também ultrapassaram os limites dos ordenamentos jurídicos internos. Aliás, consoante recorda Guido Fernando Silva Soares, ${ }^{258}$ as primeiras normas internacionais com claros propósitos de prevenção surgiram na regulamentação internacional do trabalho, diante dos perigos representados pelas atividades industriais aos trabalhadores.

No Brasil, o núcleo base para a adoção do princípio da precaução já se fazia presente na Lei de Política Nacional do Meio Ambiente no Brasil - Lei n. 6938/81, através da imposição da avaliação dos impactos ambientais (AIA), ${ }^{259}$ conforme previsão em seu art. $9^{\circ}$, III, e por meio do objetivo de compatibilização do desenvolvimento econômicosocial com a preservação da qualidade do meio ambiente e do equilíbrio ecológico e a preservação e restauração dos recursos ambientais com vistas à sua utilização racional e disponibilidade permanente, de acordo com art. $4^{\circ}$, I e VI.

258. Direito internacional do meio ambiente: emergência, obrigações e responsabilidades. São Paulo: Atlas, 2001, p.580: “[...] (razão pela qual a gênese da nova política do Direito Internacional em direção à previsão deve ser buscada na análise das convenções da OIT de prevenção de acidentes de trabalho) e, depois, para o meio ambiente (as normas de segurança operacional das instalações industriais, em particular, aquelas ligadas a um setor de atividades suficientemente perigosas, como indústria nuclear, para exigir regulamentação internacional específica, com a ativa cooperação entre a OIT, a Aiea e a OMS e as primeiras convenções internacionais sobre responsabilidade por risco)".

259. A Resolução no 001/1986 do CONAMA (Conselho Nacional do Meio Ambiente) estabelece as diretrizes para implementação da AIA (Avaliação de Impacto Ambiental): Artigo $6^{\circ}$ - $\mathrm{O}$ estudo de impacto ambiental desenvolverá, no mínimo, as seguintes atividades técnicas: I - Diagnóstico ambiental da área de influência do projeto completa descrição e análise dos recursos ambientais e suas interações, tal como existem, de modo a caracterizar a situação ambiental da área, antes da implantação do projeto, considerando: a) o meio físico [...] b) o meio biológico e os ecossistemas naturais [...] c) o meio sócio-econômico [...] II - Análise dos impactos ambientais do projeto e de suas alternativas, através de identificação, previsão da magnitude e interpretação da importância dos prováveis impactos relevantes, discriminando: os impactos positivos e negativos (benéficos e adversos), diretos e indiretos, imediatos e a médio e longo prazos, temporários e permanentes; seu grau de reversibilidade; suas propriedades cumulativas e sinérgicas; a distribuição dos ônus e benefícios sociais. III - Definição das medidas mitigadoras dos impactos negativos, entre elas os equipamentos de controle e sistemas de tratamento de despejos, avaliando a eficiência de cada uma delas. IV - Elaboração do programa de acompanhamento e monitoramento (os impactos positivos e negativos, indicando os fatores e parâmetros a serem considerados. 
Registre-se que a avaliação de impacto ambiental (AIA) é um dos instrumentos jurídicos capazes de materializar o princípio da precaução (e também da prevenção) no Brasil, inclusive por exigência da Constituição Federal, em seu art. 225, § $1^{\mathrm{o}}, \mathrm{IV},{ }^{260}$ dispositivo que em seu caput estabelece o dever tanto do Poder Público como de toda a coletividade de proteger e preservar o meio ambiente para presentes e futuras gerações.

Duas convenções internacionais ratificadas pelo Brasil inseriram o princípio da precaução no ordenamento jurídico: a Convenção da Diversidade Biológica, ${ }^{261}$ que assim estabelece em seu preâmbulo: “[...] a falta de plena certeza científica não deve ser usada como razão para postergar medidas para evitar ou minimizar essa ameaça"; bem como a Convenção-Quadro das Nações Unidas sobre a Mudança do Clima, ${ }^{262}$ a qual dispõe: "Princípio 3. As partes devem adotar medidas de precaução para prever, evitar ou minimizar as causas da mudança do clima e mitigar seus efeitos negativos. Quando surgirem ameaças de danos sérios ou irreversíveis, a falta de plena certeza científica não deve ser usada como razão para postergar essas medidas, levando em conta que as políticas e medidas adotadas para enfrentar a mudança do clima devem ser eficazes em função dos custos, de modo a assegurar benefícios mundiais ao menor custo possível."

Sob o aspecto criminal, a não adoção de medidas de precaução em caso de risco ambiental grave ou irreversível quando exigido pela autoridade competente foi tipificada à categoria de ilícito penal pela Lei de Crimes Ambientais - Lei n. 9.605/98, em seu art. 54, $\S 3^{\circ}$.

Não se olvide que o princípio da precaução (igualmente o da prevenção) também informa o Código de Defesa do Consumidor - Lei n. 8078/90, quando estabelece

260. Constituição Federal de 1988 - Art. 225 - Todos têm direito ao meio ambiente ecologicamente equilibrado, bem de uso comum do povo e essencial à sadia qualidade de vida, impondo-se ao Poder Público e à coletividade o dever de defendê-lo e preservá-lo para as presentes e futuras gerações. $\S \mathbf{1}^{\mathbf{0}}$ Para assegurar a efetividade desse direito, incumbe ao Poder Público: IV - exigir, na forma da lei, para instalação de obra ou atividade potencialmente causadora de significativa degradação do meio ambiente, estudo prévio de impacto ambiental, a que se dará publicidade.

261. Em 05/06/92 referida convenção foi assinada no Rio de Janeiro, e posteriormente ratificada pelo Congresso Nacional pelo Decreto Legislativo n. 2 de 03/02/94, tendo entrado em vigor no Brasil em 29/05/94.

262. Em 09/05/92 referida convenção foi assinada em New York, ratificada pelo Congresso Nacional pelo Decreto Legislativo n. 1 de 03/02/94, e passou a vigorar em 29/05/94. 
o direito básico à segurança e à saúde do consumidor (art. $6^{\circ}$, I) bem como a efetiva prevenção de danos patrimoniais, morais, individuais, coletivos e difusos assegura proteção contra riscos decorrentes do mercado de consumo (art. $6^{\circ}$, VI). Para tanto, o Código de Defesa do Consumidor estabelece deveres para a efetivação da prevenção de danos. Os deveres positivos são expressos basicamente no dever de informar sobre os riscos dos produtos e serviços (arts. $6^{\circ}$, III, $8^{\circ}$ e $9^{\circ}$ ). Quanto aos deveres negativos (de abstenção), destaca-se o de não introduzir no mercado produtos que sabe (aplicação do princípio da prevenção - riscos certos), ou que deveria saber (aplicação do princípio da precaução - riscos incertos) apresentar alto grau de nocividade ou periculosidade à saúde e à segurança dos consumidores (art. 10, caput). ${ }^{263}$ Ademais, o art. $7^{\circ}$ da mesma lei permite a interface com outras fontes, ao configurar-se em uma cláusula de abertura ${ }^{264}$ para outros direitos sistematicamente previstos.

Também a Lei de Biossegurança - Lei n. 11.105/05, que estabelece normas de segurança e fiscalização de atividades que envolvam organismos geneticamente modificados (OGM), bem como células-tronco embrionárias, por sua vez, faz expressa referência ao princípio da precaução em seu art. $1^{\text {o }}{ }^{265}$ Contudo, ao não indicar critérios de concretização do princípio da precaução, esta lei teve a sua constitucionalidade questionada em duas oportunidades. Com relação à arguição de inconstitucionalidade de seu art. $5^{\circ}$, que permite a utilização de células-tronco embrionárias para fins de pesquisa e terapia, a mesma foi afastada pelo STF em julgamento da Ação Direta de Inconstitucionalidade (ADI 3510). ${ }^{266}$ Outro ponto polêmico diz respeito à arguição de

263. Bruno MIRAGEM observa que: “A prevenção neste sentido, não representaria apenas a adoção de providências materiais para evitar a realização do dano, mas de modo igual, as providências tendentes ao desestímulo dos fornecedores que ofendam os direitos dos consumidores a não repetir esta conduta, bem como de exemplo aos demais agentes econômicos para que não reproduzam tal comportamento". Direito do consumidor. São Paulo: Editora Revista dos Tribunais, 2008, p.132.

264. Lei 8078/90 - Art. $7^{\circ}$. Os direitos previstos neste Código não excluem outros decorrentes de tratados ou convenções internacionais de que o Brasil seja signatário, da legislação interna ordinária, de regulamentos expedidos pelas autoridades administrativas competentes, bem como dos que derivem dos princípios gerais do direito, analogia, costumes e equidade.

265. Lei $11.105 / 05$ - Artigo $1^{\circ}$ : Esta Lei estabelece normas de segurança e mecanismos de fiscalização sobre a construção, o cultivo, a produção, a manipulação, o transporte, a transferência, a importação, a exportação, o armazenamento, a pesquisa, a comercialização, o consumo, a liberação no meio ambiente e o descarte de organismos geneticamente modificados - OGM e seus derivados, tendo como diretrizes o estímulo ao avanço científico na área de biossegurança e biotecnologia, a proteção à vida e à saúde humana, animal e vegetal, e a observância do princípio da precaução para a proteção do meio ambiente.

266. Brasil - Supremo Tribunal Federal - Tribunal Pleno - ADI: 3510 DF - Relator: Min. AYRES BRITTO - Data de Julgamento: 29/05/2008 - Data de Publicação: DJe-096 27/05/2010. 
inconstitucionalidade (ADI 3526), ${ }^{267}$ acerca das competências atribuídas pela lei à CTNBio - art. 14, e a liberação da comercialização de soja transgênica no Brasil.

A seu turno, a Política Nacional de Resíduos Sólidos - Lei n. 12.305/10, que estabelece diretrizes para o gerenciamento de resíduos, através de seu art. $6^{\circ}$, inciso I, adota o princípio da precaução, bem como o da prevenção, como contribuição para a efetivação do desenvolvimento sustentável e precursor de uma visão sistêmica na gestão dos resíduos, ${ }^{268}$ que considere variáveis nos níveis ambiental, social, cultural, econômica, tecnológica e de saúde pública.

Igualmente, através da implementação da Política Nacional de Proteção e Defesa Civil - Lei n. 12.608/12, foi criada uma estrutura jurídica específica para a prevenção de desastres ambientais, caracterizados pela incerteza, magnitude e imprevisibilidade, através de uma abordagem sistêmica das ações de prevenção, mitigação, preparação, resposta e recuperação (art. $4^{\circ}$, inciso II), com ênfase na prioridade às ações preventivas relacionadas à diminuição de desastres (art. $4^{\mathrm{o}}$, inciso III). Note-se que a implementação de ações como identificação, mapeamento e monitoramento de riscos é prevista como um dever dos poderes públicos de todas as esferas (art. $2^{\circ}$ ), com aplicação evidente do princípio da precaução, ao estabelecer que "A incerteza quanto ao risco de desastre não constituirá óbice para a adoção das medidas preventivas e mitigadoras da situação de risco" $\left(\operatorname{art.} 2^{\circ}, \S 2^{\circ}\right)$.

Importante observar que esta lei é considerada um marco no "Direito dos Desastres" no Brasil, e em consequência, para a Responsabilidade Civil Preventiva, pois "serve de base estruturante para a superação de um modelo meramente reativo a eventos catastróficos em direção a um círculo virtuoso de gestão dos riscos catastróficos”, pois permite reconfigurar "o centro gravitacional de todo o sistema jurídico no tratamento dos

267. Ação Direta de Inconstitucionalidade 3526 disponível para consulta no endereço eletrônico:. http://www.stf.jus.br/portal/geral/verPdfPaginado.asp?id=436060\&tipo=TP\&descricao=ADI/3526>. Acesso em: 22 set./2013.

268. Patrícia Faga Iglecias LEMOS observa que: "Nos termos da Política Nacional de Resíduos Sólidos, são responsáveis pelos resíduos os fabricantes, os importadores, os distribuidores, os comerciantes, os consumidores e os titulares de serviços públicos de limpeza urbana e de manejo de resíduos. Defendemos a mais ampla interpretação dos gestores de risco, de forma a abarcar também a figura do mero possuidor de resíduos, com base na sistemática geral da Lei da Política Nacional do Meio Ambiente". Resíduos sólidos e responsabilidade civil pós-consumo. São Paulo: Editora Revista dos Tribunais, 2011, p.241. 
desastres, institucionalizando a prioridade funcional preventiva". ${ }^{269}$

De todo o exposto, denota-se que o princípio da precaução se expandiu para além das áreas tradicionais do ambientalismo, ao atuar igualmente no domínio da proteção da saúde e integridade física humana em relação aos "novos riscos" verificados na Sociedade de Riscos: riscos nucleares (cuja realidade é devastadora, a exemplo de Tchernobyl e Fukushima); riscos sanitários representados pelas indústrias farmacêuticas, agroalimentares e químicas, pela nanotecnologia e biotecnologia; riscos apresentados pela exposição às energias eletromagnéticas; ${ }^{270}$ riscos relacionados ao consumo em geral; riscos de desastres, entre outros.

Ainda com relação ao âmbito de aplicação, o princípio da precaução comporta a obrigação de proteção dos vulneráveis através da responsabilidade civil, aqui compreendidos tanto as gerações futuras como também os animais não humanos e a natureza considerada em sua totalidade, ou seja, os "companheiros da aventura humana (animais, plantas, rios, mares etc.)".271

No tocante às gerações futuras, o princípio da precaução aponta o caminho para o reconhecimento de um conceito de justiça aberto à perspectiva intergeracional. Para tanto, Émilie Gaillard ${ }^{272}$ destaca a necessidade de abstrair a noção de justiça do paradigma da reciprocidade, fundado na ideia de contato social entre pessoas, impossível de ser verificado quando houver distância temporal. A ultrapassagem desse paradigma implica o reconhecimento de que deve ser garantido aos sucessores da humanidade atual o acesso suficiente aos recursos que possam lhes suprir as mesmas necessidades essenciais das

269. CARVALHO, Délton Winter. As mudanças climáticas e a formação do Direito dos Desastres. Revista NEJ - Eletrônica. Vol. 18. n. 3, p.397-415, set-dez 2013, p.397-398.

270. Elza Antônia P.C Boiteux e Fernando Netto Boiteux enumeram, com base em estatística elaborada por pesquisas científicas, as doenças passíveis de serem causadas pelos campos eletromagnéticos: leucemia em adultos e crianças; câncer no cérebro de adultos e crianças; câncer de mama em homem e mulheres; campos eletromagnéticos como agente carcinogênico de "amplo espectro" para todas as espécies de câncer; aborto espontâneo; outras disfunções da reprodução ou do desenvolvimento; esclerose lateral amiotrófica; mal de Alzheimer; infarto agudo do miocárdio; suicídio; outras consequências nocivas à saúde, diversas do câncer (depressão, sensibilidade à eletricidade). Poluição eletromagnética e meio ambiente: o princípio da precaução. Porto Alegre: Sérgio Antônio Fabris editor, 2008, p.42-43.

271. SARLET, Ingo Wolfgang; FENSTERSEIFER, Tiago. Direito Constitucional Ambiental: estudos sobre a Constituição, os Direitos Fundamentais e a Proteção do Ambiente. São Paulo: Editora Revista dos Tribunais, 2011, p.160.

272. Générations futures et droit privé: vers un droit des generations futures. Paris: L.G.D.J, 2011, p.337-341. 
gerações presentes. Cria-se um novo pacto social de dimensões temporais locais e globais, que se coloca de maneira aberta à humanidade presente e futura, e para além disso, à proteção da vida como um valor em si mesmo.

A consagração desse "direito das gerações futuras", portanto, está fundamentado em dois elementos - o princípio da não discriminação temporal e o princípio da dignidade das gerações futuras, o que abre a possibilidade de recepção, pelos civilistas, de um conceito de responsabilidade intergeracional. ${ }^{273}$ Essa recepção de tutela das gerações futuras pelo Direito privado, especialmente através da responsabilidade civil, não passou despercebida aos olhos da doutrina brasileira. Com efeito, Cláudia Lima Marques e Bruno Miragem perceberam que:

\begin{abstract}
No novo direito privado, tanto a noção de tutela do interesse das futuras gerações, quanto a responsabilidade decorrente de sua atuação surgem - ainda que em estágio inicial - do desenvolvimento do princípio da precaução e seus efeitos, bem como sobre a possibilidade e conveniência de sua proteção autônoma em relação aos titulares atuais de direitos [...] Essa proteção é reconhecida em diversas relações jurídicas de direito privado, relaciona-se atualmente com a bioética e as novas formas de fecundação in vitro e a preservação de embriões pro futuro; ou ainda a identificação de novos riscos e/ou danos futuros e sua contemplação pelo instituto da responsabilidade civil, especialmente no direito ambiental. ${ }^{274}$
\end{abstract}

Se o dever fundamental de proteção em relação às gerações futuras encontra fundamento no art. 225, caput, da Constituição Federal de 1988, o mesmo dispositivo estatui similar dever de tratamento e cuidado com relação ao bem-estar animal e preservação de espécies ameaçadas de extinção, de forma a moldar a conduta humana, ex vi art. $225, \S 1^{\circ}$, VII. Trata-se da consagração do princípio de justiça intergeracional, e do princípio de justiça interespécies. ${ }^{275}$

Neste ponto, a existência pode ter por fundamento além mesmo do

273. GAILLARD, Émilie, op.cit., p.353, defende em síntese que "Le principe de précaution apparaissait, à maints égards, comme l'indicateur de l'émergence de cette nouvelle manière de penser le droit de la responsabilité qui soit ouverte à l'égard des générations futures".

274. O novo direito privado e a proteção dos vulneráveis. São Paulo: Editora Revista dos Tribunais, 2012, p.166-167.

275. SARLET, Ingo Wolfgang; FENSTERSEIFER, Tiago. Direito Constitucional Ambiental: estudos sobre a Constituição, os Direitos Fundamentais e a Proteção do Ambiente. São Paulo: Editora Revista dos Tribunais, 2011, p.154 e p. 160-162. 
personalismo ético, a ética biocêntrica mediante o reconhecimento de sua ontologia biológica com fundamento na solidariedade grupal e no direito à auto realização, como exigência de igualdade de tratamento nas situações iguais e na solidariedade universal, considerando a identidade da mesma espécie. ${ }^{276}$

Assim, o princípio da precaução ultrapassa uma lógica individualista e patrimonialista, que concebe o ambiente como propriedade a ser desfrutada, e aprofunda uma visão humanista, holística e solidarista que estimula a sensibilização para uma ética coletiva e universal.Além da expressa previsão constitucional brasileira (art. 225, caput, CF/88), é possível vislumbrar no Preâmbulo da Declaração Universal dos Direitos Humanos $^{277}$ a referência a "todos os membros da família humana", da qual se denota uma dimensão temporal que abriga todas as gerações em seu escopo de proteção, o que é reforçado pela referência aos "direitos iguais e inalienáveis", reafirmando o tratamento equitativo a todas as gerações humanas.

A estreita relação entre o princípio da precaução, o Princípio de Justiça Intergeracional e o Princípio de Justiça Interespécies é inerente ao desenvolvimento sustentável e deve nortear o critério econômico das decisões atuais sobre o uso dos recursos disponíveis. Disso decorre, conforme sugere Edith Brown Weiss, ${ }^{278}$ a razão para que a sustentabilidade seja exigida do ponto de vista normativo, com a atribuição de direitos e responsabilidades, respectivamente, às futuras e atuais gerações.

A implementação desses direitos e responsabilidades, ainda com apoio no

276. AzEvedo, Antonio Junqueira de. Crítica ao personalismo ético da Constituição da República e do Código Civil. In: AZEVEDO, Antônio Junqueira de; Tôrres, Heleno; Carbone, Paolo (orgs.). Princípios do novo Código Civil brasileiro e outros temas. Homenagem à Tullio Ascarelli. São Paulo: Quartier Latin, 2008, p.23: "Como decorrência do valor ontológico da vida, surgem outras regras, quer éticas quer jurídicas; assim, o respeito à integridade física e o respeito às condições mínimas de sobrevivência, no âmbito dos indivíduos, e o direito de proteção da natureza, no âmbito metaindividual. Daí também artigos de lei reconhecendo o direito a alimentos (até mesmo quando alimentando é culpado de sua situação), o direito á casa própria, à saúde e até mesmo, para a subsistência, o direito à propriedade em geral. Paralelamente, há as leis de proteção aos animais e as ambientais em geral, todas fundadas no valor da vida.".

277. Declaração Universal dos Direitos Humanos, adotada e proclamada pela resolução 217 A (III) da Assembleia Geral das Nações Unidas em 10 de dezembro de 1948. Preâmbulo: "Considerando que o reconhecimento da dignidade inerente a todos os membros da família humana e de seus direitos iguais e inalienáveis é o fundamento da liberdade, da justiça e da paz no mundo [...]".

278. In Fairness To Future Generations and Sustainable Development. American University International Law Review. Vol. 8, n. 1, p.19-26, 1992, p.25. 
pensamento da professora norte-americana, ${ }^{279}$ deve ser apoiada em dois níveis: estratégias amplas e ações específicas. A estratégia mais importante é dar representação aos interesses das gerações futuras nos processos de tomada de decisão atuais, moldando as ações presentes também no interesse da manutenção da higidez às futuras gerações. Essa representação deve ocorrer em diversas instâncias: na tomada de decisão administrativa, nas decisões judiciais, e sobretudo, no mercado. No Brasil, o Ministério Público na defesa dos interesses difusos, bem como os órgãos estatais criados com a finalidade específica de proteção dos interesses (por exemplo, CTNBio, IBAMA, Agências Reguladoras etc.) podem cumprir essa função representativa das futuras gerações, mediante o manejo do princípio da precaução.

A responsabilidade atual para com as gerações futuras exige a ampliação de perspectiva, em um sentido prospectivo. Isso requer, além da adaptação das instituições, investimentos econômicos, consciência pública e vontade política, a remodelação dos instrumentos jurídicos para a efetividade desse processo. Disso decorre a proposta da Responsabilidade Civil Preventiva.

\subsection{A NORMATIVIDADE DO PRINCÍPIO DA PRECAUÇÃO E SUA INTEGRAÇÃO À RESPONSABILIDADE CIVIL: UMA RELAÇÃO DIALÓGICA E DINÂMICA}

O valor normativo do princípio da precaução, o que equivale a dizer, a sua possibilidade de ser reconhecido autonomamente como norma jurídica, com possibilidade de aplicação direta aos processos judiciais, já foi objeto de dúvida ao sabor de variados argumentos, desde as suas primeiras manifestações, há aproximadamente quatro décadas. O relatório apresentado ao Primeiro Ministro da França, elaborado por Geneviève Viney e

279. WEISS, Edith Brown. In Fairness To Future Generations and Sustainable Development. American University International Law Review. Vol. 8, n. 1, p.19-26, 1992, p.25. Sintetiza a autora: "This notion conveys both rights and responsibilities. Most impor tantly, it implies that future generations have rights too. These rights have meaning only if we, the living, respect them, and in this regard, transcend the differences among countries, religions, and cultures.". 
Philippe Kourilsky, ${ }^{280}$ apresenta três entendimentos acerca dessa justiciabilidade do princípio da precaução, a seguir expostos.

Em primeiro plano, observa-se que referido princípio já foi assimilado a um "standard", 281 na vertente "standard de julgamento"282 - uma norma dotada de flexibilidade e indeterminação provisória de conteúdo, à disposição do magistrado que definirá casuisticamente o seu escopo, dependendo dos interesses em concreto; e no modal "standard interpretativo da conduta do agente"283 - em que o comportamento do responsável com relação à observância de medidas de prevenção e precaução seria relevante para a fixação do quantum devido.

De outro lado, há entendimentos que negam autonomia jurídica ao mencionado princípio, sob a consideração de que seria uma simples diretiva (soft law) destinada a orientar a ação do legislador e de autoridades administrativas regulatórias, sem aplicabilidade imediata e alcance cogente. Esta é a posição adotada por Nicolas de Sadeleer, ${ }^{284}$ ao abordar a integração de conceitos de soft law no direito convencional. Para o jurista francês, a referência ao princípio da precaução em declarações internacionais, como o Princípio 15 da "Declaração do Rio de Janeiro", não incorpora os traços necessários para o seu reconhecimento como norma jurídica, o que só ocorre de acordo com a natureza do texto que o enuncia.

De fato, é sabido que as declarações internacionais não passam pelo procedimento de ratificação do Poder Legislativo, ao contrário das convenções ou tratados, que se tornam obrigatórios no direito interno após a sua ratificação e entrada em vigor.

280. Le principe de précaution. Paris: Odile Jacob, 2000, p.124-126.

281. Teresa Ancona LOPEZ explica: "Em suma, o standard não é nem o princípio, nem a cláusula geral, mas, dentro da técnica jurídica, pode aparecer como conteúdo da cláusula geral, como conceito flexível do princípio e pode se igualar aos conceitos vagos ou indeterminados, pois é "norma em branco". O standard é norma, como o princípio, mas não é regra, pois esta contém apenas a fattispecie." Princípio da Precaução e Evolução da Responsabilidade Civil. São Paulo: Quartier Latin, 2010, p.95.

282. LASCOUMES, Pierre. La précaution, un nouveau standard de jugement. Revue Esprit. Novembre 1997. Disponível em <http://www.esprit.presse.fr/archive/review/article.php? code=10371\&folder=2>. Acesso: 01 set. 2013.

283. LEVY, Daniel de Andrade. Responsabilidade civil: de um direito dos danos a um direito das condutas lesivas. São Paulo: Atlas, 2012, p.158-161.

284. O Estatuto do Princípio da Precaução no Direito Internacional. In: VARELLA, Marcelo Dias; PlAtiAU, Ana Flávia Barros (Org.). Princípio da precaução. Belo Horizonte: Del Rey, 2004, p.5051. 
Contudo, apesar de não apresentarem o caráter de obrigatoriedade, é inconteste que as declarações de princípios repercutem mundialmente para a integração dos mesmos com uma tipologia jurídica pelos Estados, a exemplo do Brasil, que determina a aplicação do princípio da precaução em diversas legislações, consoante já exposto no capítulo anterior.

Por fim, a terceira posição evidenciada pelos autores franceses é a que admite o princípio da precaução como um princípio efetivamente integrante do ordenamento jurídico. Esta é a posição adotada neste estudo em função da realidade brasileira.

O princípio da precaução, de reconhecido valor normativo, porém dotado de natureza principiológica, persegue algumas utilidades, de acordo com Olivier Godard:

O propósito dos princípios é fornecer um fundamento para regras mais precisas e critérios válidos para circunstâncias particulares; ao fazê-lo, eles articulam valores sociais aceitos e legitimam formas de ação em termos abstratos. Estabelecem um significado que dá direção e ilumina procedimentos institucionais instituídos ou propostos. Constituem ponto de referência em um processo de coordenação que necessita acomodar inúmeras transformações e grande diversidade empírica. Eventualmente, os princípios estimulam mudanças no sistema normativo estabelecido. ${ }^{285}$

Por vezes questionado como indefinido e de pouca operacionalidade, ${ }^{286}$ tais críticas não se coadunam com a precisa compreensão do princípio da precaução enquanto norma principiológica, portadora de um sentido geral orientador, capaz de informar o sistema jurídico como um todo e reestruturar a ordem vigente, em especial, ao integrar o sistema da responsabilidade civil provocando uma reavaliação em sua função e pressupostos.

Com efeito, embora a sua origem esteja relacionada ao Direito Ambiental, a elaboração de um "princípio geral de precaução" aplicável a outros ramos do Direito pode

285. GODARD, Olivier. The precautionary principle and chemical risks. Ecole Polytechnique. Centre National de la Recherche Scientifique. April/2012. Disponível em: http://< http://hal.archivesouvertes.fr/docs/00/68/97/61/PDF/cahier_de_recherche_2012-17.pdf.>. Acesso em: 26 set./2013. Tradução livre. No original: "Their purpose is to provide a broad base for more precise rules and criteria valuable for particular circumstances; in doing so, they articulate agreed social values and legitimate forms of commitment into action in rather abstracts terms."

286. QUÉZEL-AMBRUNAZ, Christophe. Essai sur la causalité em droit de la responsabilité civile. Paris: Dalloz, 2010, p.413: "Le champ d'application du principe de précaution n'est pas défini." 
resultar de diversos mecanismos jurídico-interpretativos, tais como sugere Mathilde Boutonnet, ${ }^{287}$ no tocante às técnicas de indução-dedução e "déambulation".

Assim, a partir da multiplicidade de fontes normativas do princípio em análise, é possível induzir um princípio da precaução que percorra diferentes ramos do direito interno, oscilando entre o direito privado e o direito público. Uma vez concluída esta indução, que resulta no princípio geral da precaução, a partir do raciocínio dedutivo, por sua vez, resultaria a criação do subprincípio da precaução, derivado daquele geral, com atuação na responsabilidade civil, bem como nos diversos ramos do Direito, a exemplo do sanitário, consumidor, administrativo, securitário, biodireito, concorrência e até mesmo no direito penal.

Já a outra técnica referida - "déambulation", diz respeito à capacidade de um princípio ser aplicado em ordens jurídicas diversas, ultrapassando fronteiras, por ser a expressão de uma consciência jurídica verificada em um contexto amplo. Considerando o direito interno, a "déambulation" do princípio da precaução ao direito privado, com especial aplicação à responsabilidade civil, poderia ocorrer a partir do seu enquadramento como um princípio geral de direito. ${ }^{288}$

Além dos referidos mecanismos tendentes a elaborar um "princípio geral de precaução" aplicável aos diversos domínios jurídicos, cabe ainda, em consequência da visão funcional do Direito, informada por uma axiologia ética, solidária e humanista, conforme já tratado nos capítulos precedentes, destacar a metodologia do "diálogo das fontes" (Dialogue des sources), como um método de interpretação, integração e aplicação de normas capaz de validar e legitimar a inserção do princípio da precaução (bem como prevenção) enquanto princípio estruturante da Responsabilidade Civil Preventiva, conforme descrição de Erick Jayme:

Quando se fala em comunicação em direito internacional privado, o fenômeno mais importante é o fato de que a solução de conflitos de lei surge como o resultado de um diálogo entre as fontes mais heterogêneas. Os direitos, constituições, convenções

287. Referidas técnicas foram aqui abordadas com base na exposição realizada por BOUTONNET, Mathilde. Le principe de précaution en droit de la responsabilité civile. Paris: L.G.D.J., 2005, p.148-152.

288. BOUTONNET, Mathilde, op.cit., p.151, em língua original: “ Or, le principe de précaution ne pourraitil pas relever de la catégories des principes 'déambulants'?" 
internacionais, sistemas nacionais: todas essas fontes não se excluem mutuamente, elas "dialogam" umas com as outras. Os juízes devem coordenar essas fontes, ouvindo o que eles dizem. ${ }^{289}$

O alcance dessa metodologia no contexto pós-moderno do Direito, com sua inerente complexidade (riscos e incertezas) e pluralidade (múltiplas fontes normativas vinculadas à diversidade inerente ao plexo social e valorativo), favorece uma solução sistemática mais harmoniosa e móvel, entre normas de origens e características variadas, consoante exposto por Cláudia Lima Marques:

O diálogo das fontes é diálogo entre leis postas, mas também pode atingir normas narrativas de inspiração, soft law, costumes, princípios gerais, a exemplo do art. $7^{\circ}$ do $\mathrm{CDC}$, e reconhece a força dos princípios imanentes do sistema e do bloco de constitucionalidade. ${ }^{290}$

A responsabilidade civil contemporânea deve orientar-se no sentido de promover com efetividade a segurança e proteção de bens e interesses fundamentais contra a realização de danos graves. Para tanto, não é suficiente interpretar as suas regras de forma estrutural e isolada, mas sim reconhecer as suas funções na sociedade contemporânea e relacionar o seu sentido e alcance com outras normas presentes no ordenamento jurídico. Isto se faz através de uma hermenêutica concretizadora, relacionada aos efeitos da norma na realidade do caso, o que só é possível através de uma visão conjuntural, orientada pelos valores constitucionais que impulsionam à prevenção de danos e incolumidade do ser humano e do meio ambiente.

Nesse passo, os critérios clássicos para solução de antinomias ${ }^{291}$ anterioridade, especialidade e hierarquia, são adaptadas, no propósito de permitir o

289. Erik Jayme. Identité culturelle et intégration: le droit international privé postmoderne. Collected Courses of the Hague Academy of International Law 251. The Hague/Boston/London: Martinus Nijhoff Publishers, 1995, p.259. Em língua original: "Dès lors que 1'on évoque la communication en droit international privé, le phénomène le plus important est le fait que la solution des conflits de lois émerge comme résultat d'un dialogue entre les sources les plus hétérogenes. Les droits de l'homme, les constitutions, les conventions internationales, les systèmes nationaux: toutes ces sources ne s'excluent pas mutuellment; elles 'parlent" l'une à l'autre. Les juges sont tenus de coordonner ces sources en écoutant ce qu'elles disent."

290. O "diálogo das fontes" como método da nova teoria geral do direito: um tributo a Erik Jayme. In: MARQUES, Cláudia Lima (Coord). Diálogo das fontes: do conflito à coordenação de normas do direito brasileiro. São Paulo: Editora Revista dos Tribunais, 2012, p.24-25.

291. ${ }^{291}$ BOBBIO, Norberto. Teoria do ordenamento jurídico. 6 a ed. Trad. Maria Celeste C. J. Santos. Brasília: Editora Universidade de Brasília, 1995, p.92. 
intercâmbio entre normas de diferentes níveis formais e substantivos. Volvendo à lição da doutrina que introduziu esse método no Brasil, denota-se uma nova roupagem àqueles critérios que se amolda em espécies de diálogos - diálogo sistemático de coerência, diálogo sistemático de complementaridade ou subsidiariedade e diálogo sistemático de adaptação ou coordenação:

[...] a nova hierarquia, que é a coerência dada pelos valores constitucionais e a prevalência dos direitos humanos; a nova especialidade, que é a ideia de complementação ou aplicação subsidiária das normas especiais, entre elas com tempo e ordem nesta aplicação, primeiro a mais valorativa, depois, no que couberem, as outras; e a nova anterioridade, que não vem do tempo de promulgação da lei, mas sim da necessidade de adaptar o sistema cada vez que uma nova lei nele é inserida pelo legislador. ${ }^{292}$ (grifos nossos)

A jurisprudência brasileira já é sensível ao uso dessa metodologia, na busca de uma aplicação coerente de várias fontes de direito, assegurando a conformidade entre as mesmas, a supremacia dos valores constitucionais e a observância de deveres impostos para a proteção da fundamentalidade de bens e direitos, da dignidade humana e da proteção dos vulneráveis, consoante demonstração abaixo.

A adoção do "diálogo das fontes" pelos tribunais, em suas três vertentes, com especial enfoque preventivo, fica clara, por exemplo, no julgado do Tribunal Regional do Trabalho da $9^{\text {a }}$ Região, ${ }^{293}$ que reconhece o diálogo sistemático de coerência

292. MARQUES, Cláudia Lima. Op.cit., p.31.

293. Brasil - TRT 9 $9^{\mathrm{a}}$ Região - 2 $2^{\mathrm{a}}$ Turma - Processo No RO-13064/2012-001-09-00.0 - Relatora: Ana Carolina Zaina - Diário Eletrônico da Justiça do Trabalho - Data de Publicação: 01 de julho de 2013. EMENTA: MEIO AMBIENTE DO TRABALHO - ARTIGO 225 DACONSTITUIÇÃO FEDERAL DIÁLOGO DE FONTES - PROTEÇÃO PRO HOMINE - No atual contexto pós-positivista em que se situa o Direito, tem-se entendido cada vez mais que se tratando de lide que versa sobre o meio ambiente de trabalho, não basta a subsunção dos fatos aos artigos 192, 194 e 195 da CLT e tampouco às normas regulamentadoras. Há dispositivos da Lei Fundamental que devem dialogar ativamente com os preceitos legais citados, sobretudo os artigos $7^{\circ}$, XII e art. 25 da CF. Assim, há necessidade da busca da legalidade substancial que tem em mira a concretização dos princípios constitucionais e, em essência, a valorização da dignidade da pessoa humana no caso sub judice. DIREITO AMBIENTAL DO TRABALHO - PRINCÍPIO DO DESENVOLVIMENTO SUSTENTÁVEL - PRINCÍPIO DA PREVENÇÃO - CONVENÇÕES 155 e 161 DA OIT - Um dos princípios basilares do Direito Ambiental do Trabalho é o princípio do desenvolvimento sustentável, conformado na tríplice base da equidade social, do desenvolvimento econômico e na preservação do meio ambiente para as presentes e futuras gerações, possuindo estreita imbricação com o princípio da prevenção, este referente à adoção de medidas que evitem os perigos concretos e conhecidos em determinado ambiente de trabalho. [...] A poluição trabalhista é caracterizada pelo desequilíbrio do meio ambiente laboral e que conspurca contra a saúde do trabalhador, gerando consequência importante na aplicação da responsabilidade civil objetiva do empregador poluidor, nos termos do art. 4, § $1^{\circ}$ da Lei 6938/1981 (Lei da Política Nacional do Meio Ambiente). 
estabelecido entre o dever de prevenção imposto constitucionalmente para a higidez do meio ambiente laboral e as normas infraconstitucionais (legais ou regulamentadoras).

\section{Percebe-se o diálogo sistemático de complementaridade na decisão do}

Superior Tribunal de Justiça ${ }^{294}$ que estabelece a aplicação coordenada de leis especiais a fim de evitar impacto direto no meio ambiente e na disponibilidade de recursos hídricos para a população atual e futura (diálogo sistemático de complementaridade).

Por fim, visualiza-se o diálogo sistemático de adaptação, no acórdão do Tribunal de Justiça de São Paulo ${ }^{295}$ que soluciona antinomias entre normas que

294. Brasil - STJ - Segunda Turma - Resp 2007/0234852-0 - Relator Ministro Herman Benjamin - Data do julgamento 25/08/2009 - Data da publicação Dje 27/04/2011 - EMENTA - "ADMINISTRATIVO. POÇO ARTESIANO IRREGULAR. FISCALIZAÇÃO. OBJETIVOS E PRINCÍPIOS DA LEI DA POLÍTICA NACIONAL DE RECURSOS HÍDRICOS (LEI 9.433/97). COMPETÊNCIA COMUM DO MUNICÍPIO. 1. Hipótese em que se discutem os limites da competência fiscalizatória municipal relacionada à perfuração de poço artesiano e sua exploração por particular. [...] A Lei da Política Nacional de Recursos Hídricos significou notável avanço na proteção das águas no Brasil e deve ser interpretada segundo seus objetivos e princípios. 9. Três são os objetivos dorsais da Lei 9.4433/97, todos eles com repercussão na solução da presente demanda: a preservação da disponibilidade quantitativa e qualitativa de água, para as presentes e futuras gerações; a sustentabilidade dos usos da água, admitidos somente os de cunho racional; e a proteção das pessoas e do meio ambiente contra os eventos hidrológicos críticos, desiderato que ganha maior dimensão em época de mudanças climáticas. [...] 11. As águas subterrâneas são "recurso ambiental", nos exatos termos do art. $3^{\circ}$, V, da Lei da Política Nacional do Meio Ambiente (Lei 6.938/81), o que obriga o intérprete, na solução de litígios associados à gestão de recursos hídricos, a fazer uma leitura conjunta dos dois textos legais, em genuíno exercício de diálogo das fontes. 12. É evidente que a perfuração indiscriminada e desordenada de poços artesianos tem impacto direto no meio ambiente e na disponibilidade de recursos hídricos para o restante da população, de hoje e de amanhã. Feita sem controle, também põe em risco a saúde pública, por ausência de tratamento, quando for de rigor. 13. Em síntese, o Município tem competência para fiscalizar a exploração de recursos hídricos, superficiais e subterrâneos, em seu território, o que lhe permite, por certo, também coibir a perfuração e exploração de poços artesianos, no exercício legítimo de seu poder de polícia urbanístico, ambiental, sanitário e de consumo. 14. Recurso Especial provido."

295. Brasil - TJSP - 8 a Câmara de Direito Público - Ap.Cível 0025739-73.2011.8.26.0071 - Relator João Carlos Garcia - Data do julgamento: 29/01/2014 - Data do registro: 30/01/2014. EMENTA: "MANDADO DE SEGURANÇA - ZONEAMENTO URBANO - LOTEAMENTO RESIDENCIAL COM CLÁUSULAS RESTRITIVAS DE EDIFICAÇÃO INSTITUÍDAS PELO LOTEADOR MORADIA UNIFAMILIAR - NOVA LEI MUNICIPAL DE OCUPAÇÃO DO SOLO URBANO [...] REGÊNCIA SIMULTÂNEA DE NORMAS DE DIFERENTES FONTES - COEXISTÊNCIA NECESIDADE DE PRESERVAÇÃO DOS VALORES PERSEGUIDOS POR SOCIEDADE REGIDA PELO [...] Voto: [...] Concernente ao mérito e ao que se tem dos fatos, a questão posta se resume em saber se existe e como resolver antinomia normativa entre a cláusula restritiva de uso, instituída pelo loteador, em loteamento regularmente registrado, nos termos do Decreto-lei 58/37 no caso dos autos, concernente à destinação estritamente residencial das moradias e à expressa proibição de habitação coletiva (fls. 105/107) e a nova legislação municipal de parcelamento do solo, ao autorizar o uso do imóvel para serviços que denotam contradição com a finalidade restritiva de edificações de habitações unifamiliares. [...] De qualquer forma, ainda que se fizesse leitura menos cuidadosa dos textos normativos municipais, ainda assim, repita-se, não se estaria diante de antinomia que resultasse na sobreposição de uma sobre outra norma. É que a proteção do meio ambiente e do patrimônio urbanístico, nos dias de hoje, se faz por normas provindas de diferentes fontes, que convergem para a sua disciplina jurídica [...].” 
estabelecem restrições urbanístico-ambientais e posterior legislação municipal de parcelamento de solo urbano, com realce a um consensualismo solidarista, coletivo e intergeracional.

Da análise dos julgados acima referidos, percebe-se nitidamente que o diálogo de normas empreendido teve em vista a promoção de um ethos jurídico, concretizado nos princípios da precaução, assim como prevenção, que cumprem uma finalidade teleológica nas soluções concretas.

Este método de interpretação é situado na compreensão de incompletude do sistema jurídico, considerado como aberto e móvel. Pertinente aqui prestigiar o pensamento de Claus-Wilhelm Canaris, para o qual a finalidade do enquadramento do Direito enquanto sistema é o de "traduzir e realizar a adequação valorativa e a unidade interior da ordem jurídica". ${ }^{296}$ Daí a sua concepção apresentar duas características constantes: a ordem e a unidade. A ordem seria a adequação intrínseca de uma ordem normativa para a realização de valores (ordem teleológica), sendo que a determinação do sentido valorativo é histórico-social. Já a unidade interior corresponde ao fato de que as disposições normativas e valorativas do Direito estão relacionadas constantemente umas às outras, sistematizada pelos princípios gerais da ordem jurídica. Surge, desse entendimento, a definição de sistema como "uma ordem axiológica ou teleológica de princípios gerais de Direito, na qual o elemento de adequação valorativa se dirige mais à característica de ordem teleológica e o da unidade interna à característica dos princípios gerais". 297

Assim, através dessa perspectiva dialogada de normas, encontramos um caminho seguro, que reconheça a coexistência de modelos de responsabilidade civil impostos pelas condições pós-modernas. Por ela, é possível atingir uma coerência interna e externa do sistema, e abarcar o fenômeno jurídico em sua totalidade. Em especial, considerando que a estrutura da responsabilidade civil repousa sobre cláusulas gerais, essa solução assegura a validade e autoridade do instituto frente ao caráter dinâmico e crescente complexidade das relações sociais, com um caráter valorativo e promocional do Direito,

296. Pensamento sistemático e conceito de sistema na ciência do direito. Trad. A. Menezes Cordeiro. 3. Ed. Lisboa: Fundação Calouste Gulbenkian, 2002, p.23.

297. CANARIS, Claus-Wilhelm, op.cit., p.77-78. 
tendo como vértices os deveres de precaução e prevenção para o alcance da segurança e afirmação dos direitos fundamentais e dignidade humana respaldados na Constituição Federal, em uma hierarquia axiológico-normativa.

No entanto, a aplicação do princípio da precaução está vinculada à presença de condições que justifiquem a sua utilização. É o que será tratado, em sequência.

\subsection{RISCO E INCERTEZA: CONDIÇÕES PARA A APLICAÇÃO DO PRINCÍPIO DA PRECAUÇÃO}

A precisão acerca do conteúdo do princípio da precaução é um dos pontos apontados pela doutrina especializada como problemático - "a working definition", 298 diante da variedade de definições que podem ser encontradas nas normas que indicam a sua implementação.

A multiplicidade de elementos considerados a partir do princípio, permitiu o desenvolvimento de concepções diversas sobre a intensidade de sua aplicação, com posicionamentos extremados, minimalistas e intermediários. ${ }^{299}$

De um lado, com a marca de um acentuado rigor, busca-se a garantia do ilusório "risco zero" de uma atividade, impondo aos seus gestores a prova cabal de inocuidade do ato desenvolvido ou autorizado, recomendando a moratória ou suspensão definitiva da atividade se constatada qualquer possibilidade de risco. Críticas a essa posição denotam, sobretudo, a possibilidade de estagnação da atividade econômica.

Em posição radicalmente oposta, a aplicação do princípio da precaução somente deve ocorrer na presença de um risco altamente provável e suscetível de causar danos graves e irreversíveis, desde que, considerados os custos econômicos, a aplicação das medidas de precaução e seus benefícios forem menos dispendiosos do que a assunção

298. World Commission on the Ethics of Scientific Knowledge and Technology (COMEST). The Precautionary Principle. France: UNESCO, 2005, p.14.

299. Referidos posicionamentos foram retratados por VINEY, Geneviève; KOURILSKY, Philippe. Le principe de précaution. Paris: Odile Jacob, 2000, p.139-141. 
do risco, não ocorrendo, ainda, a inversão do ônus da prova em relação ao gestor.

Por fim, um entendimento moderado defende a aplicação do princípio da precaução se houver a demonstração de uma hipótese de risco cientificamente aceitável e acolhida como plausível pela comunidade científica dominante no momento da tomada de decisão. Essa compreensão permite ao gestor da atividade, e em segundo plano, ao Poder Judiciário, o manejo de mecanismos hábeis para a busca do efeito mais razoável para a hipótese concreta, como a avaliação de critérios de probabilidade apresentados pelas partes envolvidas, a análise científica mais precisa acerca do possível risco, os custos econômicos, fatores sociais, culturais, éticos, entre outros. Assim, a decisão sobre a suspensão da atividade será conjugada mediante uma plêiade de relevantes informações.

Essa aplicação variável pode ser ilustrada por um estudo realizado por Mathilde Boutonnet, com abordagem empírica, sobre a utilização do princípio da precaução na responsabilidade civil pelos tribunais franceses. A autora menciona que é possível extrair da grande maioria das decisões que tratam dos riscos potenciais relacionados, principalmente, com a implementação de antenas de telefonia móvel, saúde, medicamentos e meio ambiente, o reconhecimento induvidoso da natureza principiológica da precaução. ${ }^{300}$ Contudo, a observação jurisprudencial efetuada pela professora francesa revela que o princípio da precaução apresenta perfil "multifacetado", complexo e original, que o permite percorrer diversas áreas do Direito e cumprir objetivos múltiplos. Assim, referido princípio poderá assumir a feição de:

a) princípio geral e princípio de direito privado - pois surgido originariamente no direito internacional, passou a ocupar o direito interno inicialmente no domínio ambiental e deste, mediante o emprego do raciocínio indutivo, operou a passagem de um princípio de direito público a um princípio aplicável também ao direito privado, em especial no tocante ao direito à saúde;

b) princípio diretor e princípio normativo - essa dualidade é refletida no princípio da precaução quando, por um lado, apresenta um perfil “diretor”, sendo capaz de influenciar os pressupostos da responsabilidade, seja promovendo o alargamento da noção

300. BOUTONNET, Mathilde. Bilan et avenir du principe de précaution en droit de la responsabilité civile. Recueil Dalloz n ${ }^{\circ}$ 40, 18 novembre 2010, p.2662. 
de dano em relação ao risco incerto, seja favorecendo a prova da culpa derivado de um comportamento à luz de uma incerteza científica; e de outro, é "normativo", pois dotado de justiciabilidade, exequibilidade e sancionabilidade pelo juiz;

c) princípio de responsabilidade civil e princípio de ação - O princípio da precaução pode ser invocado como fundamento de uma ação de responsabilidade civil, assumindo a natureza de "princípio da responsabilidade civil" (assim como o princípio da responsabilidade pelo fato das coisas em relação ao guardião, o princípio de responsabilidade pelo fato de outrem em relação à pessoa que deva assumir as consequências do dano, o princípio da responsabilidade subjetiva em relação ao culpado, o princípio da reparação integral em relação ao montante correspondente ao valor do dano);

d) princípio aplicável aos fatos geradores e aos efeitos - O princípio da precaução, de um lado, é voltado aos fatos geradores de consequências danosas não realizadas, que manifestam uma situação de simples risco, anterior ao dano. Em outras palavras, à semelhança do "trouble anormal du voisinage, ${ }^{301}$ procura-se apreender o fato que está na origem do possível dano, causador de efeitos em vias de realização e não consumados. De outro turno, a precaução é um princípio de responsabilidade civil voltado à sanção de um fato gerador do qual decorrem certos riscos que são possíveis de prevenir através de medidas preventivas. ${ }^{302}$

Embora a flexibilidade normativa faça parte da natureza dos princípios jurídicos, as divergências de posições quanto ao princípio da precaução têm-se revelado como um fator de insegurança jurídica, o que obviamente não reduz a importância de sua aplicação, mas ressalta a necessidade de estabelecimento de balizas seguras para a sua utilização.

Apesar da diversidade de definições existentes acerca de seu conteúdo, é

301. Essa teoria é derivada do art. 44 do Code Civil francês, que dispõe: "La propriété est le droit de jouir et disposer des choses de la manière la plus absolue, pourvu qu'on n'en fasse pas un usage prohibé par les lois ou par les règlements." Abordagem mais detalhada é realizada na Parte II desta pesquisa, no capítulo referente ao "dano", infra.

302. BOUTONNET, Mathilde. Bilan et avenir du principe de précaution en droit de la responsabilité civile. Recueil Dalloz $\mathrm{n}^{\circ}$ 40, 18 novembre 2010, passim. A autora conclui, ao afirmar, em língua original: "Ainsi, principe de droit privé, directeur et normatif, le principe de précaution est également un principe de droit de la responsabilité tourné vers la sanction d'un fait générateur dont il découle certains risques qu'il est possible de prévenir par le biais de mesures préventives". 
possível constatar a presença de dois elementos constantes para a sua aplicação: o risco e a incerteza científica. Este aspecto reflete-se na Recomendação do Conselho Europeu sobre o princípio da precaução, ${ }^{303}$ nos seguintes termos: "7. considera que é apropriado utilizar o princípio da precaução, quando a possibilidade de efeitos nocivos para a saúde ou o ambiente for identificada e a avaliação científica preliminar com base em dados disponíveis não permitirem concluir com certeza o nível de risco."

Portanto, identificar as dimensões do risco e da incerteza apresenta-se primordial para a concretização da Responsabilidade Civil Preventiva, pois esses elementos influenciarão decisivamente a ressignificação dos pressupostos desse instituto jurídico. Passemos, a seguir, à abordagem das características centrais desses elementos.

\subsection{CONCEITO DE RISCO E TIPOLOGIA CONFORME A GRADUAÇÃO DE INCERTEZA: DO PRINCÍPIO DA PREVENÇÃO AO PRINCÍPIO DA PRECAUÇÃO}

Do conhecimento filosófico clássico, Nicola Abbagnano ${ }^{304}$ apresenta importantes lições que permitem a reflexão sobre o conceito de risco para a atualidade. Aristóteles considerava o risco como "o aproximar-se daquilo que é terrível”. Platão compreendia o risco como "belo e inerente à aceitação de certas hipóteses ou crenças". Já o existencialismo contemporâneo relaciona o risco à escolha e decisão. É nesse sentido que o referido filósofo apresenta a correlação desses elementos fundamentais para a justificação da Responsabilidade Civil Preventiva: “A pretensão implícita na decisão baseia-se numa indeterminação efetiva, ou seja, na possibilidade de que as coisas se passem de maneira diferente daquilo que eu decido; mas também se baseia no fato de eu, que decido, assumir

303. Conseil Européen. Reunión de Nice. 7-9 déc 2000. Annexe III. Résolution sur le Principe de Précaution. Disponível em <http://www.europarl.europa.eu/summits/nice2_fr.htm>. Acesso em: 25 set. 2013. Tradução livre. Em língua original: "7. considère qu'il y a lieu de recourir au principe de précaution dès lors que la possibilité d'effets nocifs sur la santé ou l'environnement est identifiée et qu'une évaluation scientifique préliminaire sur la base des données disponibles, ne permet pas de conclure avec certitude sur le niveau de risque".

304. Dicionário de filosofia. Trad. Alfredo Bosi e Ivone Castilho Benedetti. São Paulo: Martins Fontes, 2007, p.859. 
esse risco, bem como na consideração de todas as possíveis garantias que eu possa obter". 305

Ab initio, faz-se necessário distinguir conceitos próximos relacionados ao risco, como álea ou perigo. Pois bem. O risco implica um modo particular de se referir a um evento futuro contingente, através da percepção da antecipação dos seus efeitos; já o perigo compromete a segurança de uma forma conhecida, presente e real; e a álea é um acontecimento futuro e casual, sendo possível a sua não realização e por consequência, é insuscetível de estimação (neste sentido, a álea é relacionada à "sorte", ou "esperança"). ${ }^{306}$ O que efetivamente distingue o risco daquelas outras noções, não é a maior ou menor imprevisibilidade do evento, mas sim o fato de que, no risco, a antecipação do acontecimento conduz à avaliação das possíveis consequências danosas para sopesar um coeficiente de probabilidade e discernir o seu valor. Por outras palavras, no risco, ao administrador ou gestor é atribuído um caráter ativo, pois o mesmo comanda o processo avaliatório para a sua detecção e antecipação de consequências.

O risco de que se trata, para a aplicação do princípio da precaução, não se enquadra no senso comum de algo indesejável, capaz de produzir dissabores ou consequências desagradáveis. O risco derivado da noção de "Sociedade de Risco"307 diz respeito a consequências tão graves e irreversíveis, que não há como indenizar as vítimas ou retornar ao status quo ante. Além disso, a concepção de risco que surgiu com a modernidade, ${ }^{308}$ considera aquele como derivado de criações humanas, diferenciando-se da concepção neutra que já existia na pré-modernidade, que excluía a ação humana da causa

305. Nicola ABBAGNANO, op.cit., p.859.

306. Para o Código Civil brasileiro, artigo 458, aleatório é o contrato em que uma prestação pode deixar de existir em virtude de um acontecimento futuro e incerto. É o caso dos contratos de compra e venda de colheitas futuras de safras incertas, e do contrato de seguro, em que a contraprestação do segurador será adimplida se ocorrer um evento futuro previamente estabelecido na apólice.

307. BECK, Ulrich. Sociedade de Risco: rumo a uma outra modernidade. Trad. Sebastião Nascimento. São Paulo: Ed. 34, 2010, p.27-28.

308. BECK, Ulrich, op.cit., p.23: "Modernização significa o salto tecnológico de racionalização e a transformação do trabalho e da organização, englobando para além disto muito mais: a mudança dos caracteres sociais e das biografias padrão, dos estilos e formas de vida, das estruturas de poder e controle, das formas políticas de opressão e participação, das concepções de realidade e das normas cognitivas. O arado, a locomotiva a vapor e o microchip são, na concepção sociocientífica da modernização, indicadores visíveis de um processo de alcance muito mais profundo, que abrange e reconfigura toda a trama social, no qual se alteram, em ultima instância, as fontes da certeza das quais se nutre a vida". 
de riscos.

$\mathrm{Na}$ atualidade, a concepção de risco que advém da evolução da tecnologia e ciência próprias da modernidade visita diversas teorias sociais, ${ }^{309}$ cada qual com um posicionamento próprio. Nesse contexto de incerteza em que está inserido o risco, cabe indagar a existência de algum critério para a sua avaliação, que seja útil ao operador do Direito. É certo que a sua definição conceitual é muito complexa e está longe de atingir consenso, seja no meio científico, sociológico ou jurídico. Ademais, a noção de risco, que acompanha o homem no seu desenvolvimento ao longo dos séculos, é abordada por diversas disciplinas, o que o torna suscetível a múltiplas interpretações, por vezes até mesmo antagônica.

No entanto, considerando que a Responsabilidade Civil Preventiva tem como um dos escopos antever a ocorrência do possível dano, diante da existência de riscos certos (prevenção) ou incertos (precaução), torna-se importante a busca de subsídios que auxiliem a sua identificação. ${ }^{310}$

Segundo Rafaelle de Giorgi, ${ }^{311}$ o risco está relacionado com a probabilidade de que se produza um dano futuro que poderia ter sido evitado se a decisão tomada em certo momento pudesse ser outra, realizando, assim, uma conexão com o futuro, referente às certezas e incertezas que influem o processo de tomada de decisões na sociedade atual e

309. Uma análise sociológica aprofundada escapa aos propósitos da presente pesquisa. No entanto, a título de referência, é possível destacar, no âmbito da sociologia, a perspectiva culturalista do risco, de que são representantes DOUGLAS, Mary e WILDAVSKY, Aaron. Risk and culture: an essay on the selection of technological and environmental dangers. Berkeley: University of California Press, 1982; a sociedade de risco, conceito desenvolvido por BECK, Ulrick. Sociedade de Risco: rumo a uma outra modernidade. Trad. Sebastião Nascimento. São Paulo: Ed. 34, 2010; sociedade de risco associada ao conceito de modernização reflexiva, em BECK, Ulrich, GIDDENS, Anthony, LASH, Scott. Modernização reflexiva. São Paulo: Editora da Universidade Estadual Paulista, 1997; a abordagem sistêmica do risco, desenvolvida por LUHMANN, Niklas. Risk: a sociological theory. Translated by Rhodes Barret. Berlin: Walter de Gruyter, 1993; a governamentalização e o risco, idéia inicialmente tematizada por Foulcault, e posteriormente desenvolvida por autores que exploram o risco no contexto da vigilância, disciplina e regulação das populações, como LUPTON, Deborah. Risk and sociocultural theory: new directions and perspectives. Cambridge: Cambridge University Press, 1999 e NOIVILLE, Christine. Du bon gouvernement des risques. Paris: Presses Universitaires de France, 2003.

310. LOPEZ. Teresa Ancona. Princípio da Precaução e evolução da responsabilidade civil. São Paulo: Quartier Latin, 2010, p.26: "É justamente a diferença entre o risco comprovado, que tem no seu conteúdo a ameaça de perigo, e o risco hipotético ou potencial, que vai fundamentar as diferenças entre prevenção e precaução".

311. Direito, democracia e risco: vínculos com o futuro. Porto Alegre: Sérgio Antônio Fabris Editor, 1998 , p.14 e 86. 
que repercutem em sua estrutura, projetando suas consequências além do tempo presente. Diante da incerteza, destaca ainda o autor, a experiência se apresenta como um elemento de grande valia na tentativa de previsão para o futuro, na medida em que as informações que dela decorrem permitem antecipar o que pode acabar ocorrendo em determinadas situações, e auxiliar na orientação de ações.

Na observação de Niklas Luhmann, ${ }^{312}$ o conceito usual de risco aparece em oposição à noção de segurança, onde o risco é medido em um cálculo de probabilidades. Para esse sociólogo, há distinção entre risco e perigo, embora ambos estejam associados à perda potencial futura. O risco é definido quando há o reconhecimento do dano relacionado à tomada de decisões próprias, e o perigo como o dano que foi causado por fontes externas àquele que sofreu a consequência. Os perigos transformam-se em riscos à medida que aumentam as ocasiões em que se deve decidir e o número de alternativas para escolher. Sustenta que é característico da sociedade moderna apontar o futuro como risco, pois se torna cada vez mais dependente da tomada de decisão, o que traz consigo a necessidade de apontar responsabilidades quando ocorrem consequências indesejadas. Em outras palavras, o risco se concretiza sempre que há uma "disfunção do sistema". Nesta perspectiva, o risco é definido como uma ou mais condições de uma variável que possui potencial para interromper um sistema, causando a sua degradação completa, o desvio de metas preestabelecidas ou a implicação do aumento dos recursos referentes a pessoal, equipamentos, instalações, materiais ou meios financeiros.

A seu turno, a definição de risco, para Anthony Giddens, ${ }^{313}$ é realizada a partir de sete perfis: a globalização do risco no sentido de intensidade; globalização do risco no sentido de expansão da quantidade de eventos contingentes que afetam grande quantidade de pessoas; risco derivado do meio ambiente criado, ou seja, a infusão de conhecimento humano no ambiente material; desenvolvimento de riscos ambientais institucionalizados; consciência do risco como risco, ou seja, as lacunas de conhecimento não podem ser convertidas em certeza pelo conhecimento não científico; consciência dos riscos pelo grande público; consciência das limitações da perícia.

312. A elaboração do complexo pensamento de Niklas Luhmann poderá ser consultada em Risk: a sociological theory. Translated by Rhodes Barret. Berlin: Walter de Gruyter, 1993, p.36.

313. As consequências da modernidade. São Paulo: editora UNESP, 1991, p.111-112. 
Dos pensamentos expostos, pode-se extrair a certeza da complexidade existente na definição do risco para as ciências sociais. Contudo, a constância ou repetição de elementos nos diversos enfoques parece convergir para um núcleo comum, reunidos abaixo em um esforço de síntese:

a) a noção de risco pressupõe cenários de incerteza;

b) a noção de risco remete à ideia de probabilidade de sua materialização;

c) a concretização do risco traz um efeito negativo;

d) a consciência da sociedade sobre os riscos aos quais está sujeita é incompleta;

e) a sociedade depende dos conhecimentos técnicos e científicos para identificação do risco;

f) o risco pode ser reconhecido, evitado ou controlado, mas não dissipado;

g) novas formas de risco emergem continuamente, em decorrência do incremento da complexidade social, e até mesmo da ampliação do conhecimento técnico e científico;

h) os estudos sobre as causas dos riscos permitem a elaboração de um planejamento mínimo e ação preventiva.

O risco, na verdade, acompanha o ser humano no seu desenvolvimento ao longo dos séculos. Porém, a percepção atual acerca dos riscos tende a compreendê-los como consequência de racionalidade limitada e insegurança, que deve ser evitada. Neste sentido, é a conclusão de Franz Josef Brüseke, para o qual:

Em outras áreas podemos observar, nos últimos tempos, grandes avanços referente à percepção de padrões de possibilidades, relevantes para a sociedade. Assim, depois de uma fase meramente reativa, quando se tratava de catástrofes, surgem cada ano mais estudos sobre as causas delas, para chegar a um mínimo de planejamento e ação preventiva (...) Estudos sobre riscos, são estudos sobre um determinado campo de eventos onde estão em jogo perdas indesejadas. A contingência do Ser permite que possamos cercar estes riscos com meios probalísticos, permite que possamos trilhar outros caminhos do que os mais 
arriscados. A possibilidade, não obstante, não deve ser confundida com a probabilidade, como a probabilidade, tampouco, é um sinônimo de contingência. ${ }^{314}$

A digressão exposta poderá auxiliar o operador do Direito a encontrar um critério apriorístico para a fixação da ideia de risco no âmbito jurídico, especialmente para a aplicação da Responsabilidade Civil Preventiva. Como bem ressaltou Geneviève Viney e Phillippe Koulrilsky, "a avaliação dos riscos é etapa essencial da racionalização dos riscos que deve levar a separar os riscos potenciais do delírio e da simples apreensão". ${ }^{315}$

Nesse ponto, destaca-se a antecipação da suspeita de risco como a nota essencial para a aplicação do princípio da precaução, e esse olhar de cautela prospectiva é marcada pela limitação dos conhecimentos científicos e a da previsibilidade de suas consequências.

Aliás, a distinção entre os princípios da precaução e da prevenção, reside justamente na graduação da incerteza acerca dos riscos, considerados incertos para o primeiro, e certos para o segundo.

Na lição de Nicolas de Sadeleer, o princípio da prevenção será instado a intervir quando a concepção de risco utilizado se referir aos riscos aonde a relação de causa e efeito é conhecida, ou seja, são riscos certos. Neste caso, "as ameaças são tangíveis, a situação pode rapidamente se tornar crítica, e portanto, é conveniente prevenir a tempo as consequências prejudiciais que poderão ocorrer".316 Já o princípio da precaução se distingue da prevenção porque as ameaças são potenciais, incertas, hipotéticas, ou seja, caracterizam situações em que a possibilidade de ocorrência de danos não foram provadas conclusivamente, e justamente por isso, exige cautela e ações preventivas, o que se traduz em um marco ainda mais avançado para a redução do risco.

Pode-se, portanto, resumir a distinção, ao afirmar que para a aplicação de

314. Riesgo y Contingencia. In: VARELLA, Marcelo Dias (Org.). Derecho, sociedad y riegos: la sociedad contemporánea vista através de la idea de riesgo. Brasília: UNICEUB e UNITAR, 2006, p.112. Tradução livre.

315. Le Principe de Précaution. Paris: Éditions Odile Jacob, 2000, p.41; “Toute démarche de précaution commence par la difficile analyse des risques. Il va de soi que 1 risque doit être défini, évalué et gradué. Cette proposition est moins élémentaire qu'il n'y paraît. Elle est l'étape essentielle de rationalisation des risques qui doit conduire à séparer le risque potentiel du fantasme et de la simple appréhension."

316. Les príncipes du pollueur-payeur, de prévention et de précaution: essai sur la genèse et la portée juridique de quelques príncipes du droit de l'environnement. Bruxelles: Bruylant, 1999, p.136. 
critérios de prevenção, o risco é identificado, um evento provável, ao passo que para a incidência da precaução, plaina uma incerteza científica acerca da existência de um risco grave, pois esse não foi suficientemente demonstrado

Diante destes caracteres, é forçoso concluir que o critério da probabilidade para avaliação do risco, embora seja aplicável às situações em que esse seja certo, e portanto, passível de aplicação do princípio da prevenção, não é um critério a ser utilizado em situações de risco incerto ou potencial, às quais se aplica o princípio da precaução.

Com efeito, na presença de uma incerteza científica acerca do risco, o critério que melhor indica a aplicação do princípio da precaução é a plausibilidade, o que evidencia um motivo de inquietude ou dúvida legítima. Para verificação da plausibilidade, a seu turno, é possível estabelecer indicativos. Assim, a existência de um possível risco deve ser indicada por alguma suspeita advinda de experiências anteriores, como por exemplo, as primeiras culturas de milho transgênico pareciam indicar que esta espécie de milho poderia matar borboletas. ${ }^{317}$ Além disso, a aferição de plausibilidade pode decorrer de um aspecto puramente teórico, desde que cientificamente defensável, ou seja, se a suspeita de risco for demonstrada com rigor metodológico, mesmo que por um número minoritário de pesquisadores.

O Relatório da UNESCO sobre o princípio da precaução aponta elementos distintivos claros entre probabilidade e plausibilidade, cuja consulta não se pode, nesta oportunidade, dispensar:

Quando julgamos que uma hipótese é plausível porém outra não é, não estamos dizendo que a hipótese plausível é mais provável que a implausível, embora estejamos dizendo que a hipótese plausível possui maior possibilidade que a outra. Nós somente podemos julgar a probabilidade quando possuirmos evidências suficientes para realizar essa determinação. Quando faltar evidências suficientes sobre as duas hipóteses, precisamos suspender nosso julgamento sobre qual hipótese é verdadeira porque somos ignorantes sobre ela. Porém não precisamos suspender nosso julgamento prático, porque ainda precisamos decidir como agir com respeito à estas possíveis hipóteses. Então, se eu detectar um novo grânulo em minha pele e minhas duas hipóteses são "é cancerígeno" e "é benigno", eu não tenho que determinar que o grânulo é provavelmente cancerígeno para ir ao médico e avaliar. Eu

317. VOIDEY, Nadège. Le risque en droit civil. Paris: Presses Universitaires d'Aix-Marseille, 2005, p.164. 
posso considerar a hipótese do câncer como uma séria possibilidade mesmo se eu não a considero como verdadeira ou mesmo minimamente provável. ${ }^{318}$

Assim, enquanto a prevenção consiste em utilizar as medidas necessárias para a não ocorrência de um evento previsivel sobre o qual é factível uma avaliação de probabilidade, na precaução plaina uma incerteza científica difusa sobre a qual não é possível um raciocínio de probabilidade, mas sim de plausibilidade, o que equivale a dizer, uma avaliação acerca de sua real possibilidade.

Comparando-se o princípio da precaução com o da prevenção, observa-se que o segundo exige que os riscos comprovados sejam banidos, ou ao menos informados, enquanto o primeiro determina que a ação para eliminar possíveis danos seja assegurada antes mesmo que o risco seja estabelecido com evidência científica absoluta.

O princípio da precaução, portanto, exige um plus com relação ao princípio da prevenção, pois, juntamente com o risco (elemento constante na identificação dos dois princípios mencionados), a precaução exige a mais a verificação de incerteza científica quanto à evidência do possível risco.

A distinção é relevante sob o ponto de vista da causalidade. Nas situações passíveis de aplicação do princípio da prevenção, previne-se porque já é sabido com antecedência quais as consequências da prática de determinada atividade ou produto. A seu turno, com relação ao emprego do princípio da precaução, previne-se porque não é possível estabelecer quais as consequências que determinada atividade ou produto pode causar. E por isso, a perquirição da relação de causalidade para o estabelecimento de responsabilidade deverá partir do reconhecimento de nexos de imputação que se diferenciam da análise tradicional empregada na responsabilidade reparatória e retrospectiva, conforme será abordado em momento próprio nesta pesquisa.

Desenhadas as distinções doutrinárias entre os dois princípios estruturantes da Responsabilidade Civil Preventiva, é importante mencionar que ambos tem em comum a imposição de uma atuação preventiva frente aos riscos, exigindo para tanto, a responsabilidade compartilhada de diversos atores, cabendo ao Estado a criação de 
instrumentos normativos para uma política preventiva, à Administração Pública e empresas privadas a sua implementação, ao Judiciário a garantia de que sua aplicação atende aos preceitos legais, e à sociedade em geral o dever de adotar uma responsabilidade jurídica de prevenção, da qual decorrem obrigações de fazer e de não fazer. ${ }^{319}$

Nesse âmbito, dois tipos de medidas preventivas podem ser acionadas, conforme lição de Michel Prieur: ${ }^{320}$ a prevenção clássica, para evitar a ocorrência de danos que sabemos de antemão as consequências (por exemplo, explosões ou incêndios relacionados ao uso de inflamáveis ou explosivos, no Brasil, normatizadas através da aplicação dos arts. $9^{\circ}$ e 10 do Código de Defesa do Consumidor, que impõe aos fornecedores um dever geral de vigilância e informação, inclusive pós-contratual); ${ }^{321}$ bem como a prevenção reforçada pela precaução, a fim de evitar a ocorrência de danos que não se sabe discernir as consequências em virtude da incerteza ou controvérsia científica acerca do seu real impacto (por exemplo, os efeitos a longo prazo dos resíduos químicos nos oceanos, da radiação, dos organismos geneticamente modificados, dos pesticidas). A

319. LEITE, José Rubens Morato; AYALA, Patryck de Araújo. Dano ambiental: do individual ao coletivo extrapatrimonial. $4^{\mathrm{a}}$ ed. São Paulo: RT, 2011, p.57: “[...] é importante salientar que esta tarefa de atuar, preventivamente, deve ser vista como uma responsabilidade compartilhada, exigindo uma atuação de todos os setores da sociedade, cabendo ao Estado criar instrumentos normativos e política ambiental preventiva, conforme já pontuado."

320. Le Principe de Précaution. Disponível em: http://www.legiscompare.fr/site-web/IMG/pdf/2Prieur.pdf. Acesso em: 25 set./2013. No original: “Aussi doit-on dorénavant clairement distinguer deux types de mesures de prévention : la prévention classique pour éviter la survenance de dommages dont on connaît par avance les conséquences (par exemple en ce qui concerne les explosions ou les incendies liés à l'usage de produits inflammables ou explosifs, ou les rejets dans les eaux de produits toxiques) et la prévention renforcée ou prévention - précaution pour éviter la survenance de dommages dont on ne connaît pas les conséquences en raison de l'incertitude scientifique ou de la controverse scientifique concernant leurs conséquences réelles (par exemple les effets à long terme de rejets chimiques dans les océans, les effets des faibles doses de radioactivité, les effets des organismes génétiquement modifiés, les effets des pesticides ). L'incertitude dont il s'agit n'est pas liée à la survenance du risque mais aux conséquences que cette survenance peut déclencher."

321. Claudia Lima MARQues acrescenta: "Pode-se interpretar o art. 10 como instituindo um dever póscontratual, isto é, um dever de vigilância, dever de informar o consumidor, se "tiver conhecimento" da periculosidade de um produto, que ajudou a colocar no mercado. Assim, o farmacêutico informado sobre a proibição de determinado remédio, que causa o câncer, deve informar seus ex-parceiros contratuais da periculosidade do produto vendido, afixando, por exemplo, um cartaz no estabelecimento comercial. Assim, também, o supermercado que descobre que determinado queijo vendido está causando intoxicação nas pessoas que o ingerem, determinada revendedora de carros que descobre que algumas das peças vendidas vieram com defeito de fábrica nos freios. São casos em que os princípios da transparência e da boa-fé nas relações contratuais irão se unir aos princípios da proteção da confiança do consumidor na segurança normal do produto vendido, para impor um dever nitidamente pós-contratual ao fornecedor direto, e não simplesmente extracontratual, como o é para o fabricante". In: MARQUES, Cláudia Lima; BENJAMIN, Antônio Herman V.; MIRAGEM, Bruno. Comentários ao Código de Defesa do Consumidor. 2. ed. rev., atual. e ampl. São Paulo: Editora Revista dos Tribunais, 2006, p.251. 
incerteza em questão não está relacionada com a ocorrência do risco, mas com as consequências que podem advir de sua ocorrência.

Uma outra nota distintiva pode ser destacada. A prevenção admite uma avaliação completa dos riscos, que são passíveis de estimação quantitativa quanto à exposição ao indivíduo e à coletividade e quanto aos danos esperados. Isso oferece uma base sólida para políticas de prevenção, e sobretudo, fornece os elementos necessários para cobertura securitária (segurança social ou empresas seguradoras privadas). Já a incerteza científica inerente à precaução não oferece essa mesma facilidade para a identificação das políticas de precaução, tampouco fornece elementos sobre os quais é realizado o cálculo de risco para contratação de seguros. Isso pode ser um incentivo para o interesse em reforçar os limiares de segurança com o intuito de impedir que os danos efetivamente venham a acontecer. $^{322}$ Realizada a distinção entre riscos certos (aplicação do princípio da prevenção) e incertos (aplicação do princípio da precaução), é importante destacar que, mesmo com relação aos riscos certos, a incerteza se fará presente. Isto porque, ainda que o perigo seja conhecido e a probabilidade de ocorrência do dano passível de estimação, a incerteza dirá respeito exatamente ao momento, assim como à magnitude desses danos. Ou seja, enquanto na precaução a incerteza reside na evidência dos riscos, na prevenção ela se verifica com relação ao instante da ocorrência dos danos estimados, bem como à sua extensão. Disso decorre que ambas as possibilidades - riscos certos ou incertos, guardam relevância para a atuação dos mecanismos da Responsabilidade Civil Preventiva.

\subsection{INCERTEZA CIENTÍFICA E GERENCIAMENTO PROPORCIONAL DE RISCOS: AVALIAÇÃO (RISK ASSESSMENT), GESTÃO (RISK MANAGEMENT) E INFORMAÇÃO (RISK COMMUNICATION)}

$\mathrm{Na}$ civilização técnicocientífica, os riscos associados a novas tecnologias são incertos e abrem espaço a uma vulnerabilidade imaginária, pois não podem ser identificados com precisão. Embora virtual, os seus efeitos, por desconhecidos que são,

322. Nesse sentido: GODARD, Olivier. The precautionary principle and chemical risks. Ecole Polytechnique. Centre National de la Recherche Scientifique. April/2012. Disponível em: http://< http://hal.archives-ouvertes.fr/docs/00/68/97/61/PDF/cahier_de_recherche_2012-17.pdf.>. Acesso em: 26 set./2013. 
podem alcançar limites além do reparável. E no anseio de garantir o mais próximo possível o quimérico "risco zero", o raciocínio jurídico e a aplicação dos instrumentos do Direito confinam com a falta de certeza, realçando a importância dos mecanismos de gerenciamento de riscos para avaliação de sua tolerabilidade, como aprofundamento em pesquisa, uso de estatísticas e cálculo de probabilidades, perícias, veiculação de informação e pesquisas de opinião, além de sopesar os custos do gerenciamento. Destaca Teresa Ancona Lopez que "o risco deve ser avaliado dentro dos parâmetros risco/utilidade e custo/benefício. A análise social e econômica é de fundamental importância". ${ }^{323}$ Dessa forma, a segurança e dever de proteção em relação aos riscos são assegurados no domínio jurídico através da aplicação dos princípios da precaução e da prevenção.

Com relação ao princípio da precaução, grande parte das definições normativas colocam como premissa para a sua implementação a incerteza científica quanto aos riscos. Com efeito, o Princípio 15 da Declaração do Rio de Janeiro menciona “[...] a ausência de certeza absoluta [...]"; a Convenção da Diversidade Biológica, estabelece no Preâmbulo "[...] a falta de plena certeza científica [...]; a Convenção-Quadro das Nações Unidas sobre a Mudança do Clima, dispõe em seu Princípio 3, “[...] a falta de plena certeza científica [...]”; a Política Nacional de Proteção e Defesa Civil - Lei n. 12.608/12 estabelece que "[...] A incerteza quanto ao risco"; entre tantos outras normas que poderiam aqui ser mencionadas.

A realidade pós-moderna que se traduziu em uma "Sociedade de Riscos" é caracterizada por uma complexidade generalizada e pela fragmentação das bases institucionais tradicionais. Se até meados do século XX a ciência era considerada incontestável, a partir de então foi necessário reconhecer a insuficiência e a limitação de suas abordagens, bem como a multiplicidade de teorias antagônicas. É certo que, no caminhar da evolução científica, a decadência do cienticismo levou à percepção de que “estamos apenas no início da aventura", consoante ressalta com a autoridade conferida por um prêmio Nobel, o professor e cientista Ilya Prigogine:

“Assistimos ao surgimento de uma ciência que não mais se limita a situações simplificadas, idealizadas, mas nos põe diante da complexidade do mundo real, uma ciência que permite que se viva a criatividade humana, como a expressão singular de um traço fundamental

323. Princípio da precaução e evolução da responsabilidade civil. São Paulo: Quartier Latin, 2010, p.49. 
comum a todos os níveis da natureza". 324

Aqui, reside a interface entre a ciência e a lei. ${ }^{325}$ A complexidade ${ }^{326}$ tecnocientífica exige do operador jurídico contemporâneo uma compreensão plural sobre aspectos variados, locais e globais, que compõem uma moldura efêmera e instável da sociedade, do indivíduo e de suas certezas. Essa alteração na postura operativa frente à ambiguidade das próprias condições de existência estimula um processo de substituição nas formas de conjecturar as variáveis globais, destacando um novo modo de análise e ação frente à incerteza, instabilidade e efemeridade, e convida a uma investigação multidisciplinar.

A ideia fundamental da incerteza da ciência é aquela que gira em torno da coexistência de inúmeras explicações possíveis e distintas, especialmente sobre questões relacionadas ao meio ambiente e à saúde. Para ilustração, na atualidade, destacam-se como setores aonde ainda não há consenso científico acerca de suas repercussões para a vida humana e o ecossistema, a nanotecnologia, a segurança de alimentos derivados de organismos geneticamente modificados, riscos advindos das ondas eletromagnéticas de telefones celulares, riscos químicos (pesticidas, cosméticos, medicamentos) entre outros. Trata-se de sistemas complexos aonde há uma inerente dúvida, cuja avaliação de riscos deve ser realizada de forma racional, visando uma análise de custos e benefícios sociais.

A incerteza científica não se confunde com a completa falta de informação sobre possíveis consequências da tecnologia e ciência, mas sim com a falta de conhecimento conclusivo acerca de suas propriedades, que permanecem no domínio da conjectura ou hipótese, embora a pesquisa a seu respeito tenha sido formulada de acordo

324. O fim das certezas. Trad. Roberto Leal Ferreira. São Paulo: Editora da Universidade Estadual Paulista, 1996, p.14.

325. FOSTER, Caroline E. Science and the Precautionary Principle in International Courts and Tribunals: expert evidence, burden of proof and finality. Cambridge: Cambridge University Press, 2011, p.10: "This is important in the context of scientific disputes. The interface between science and law generates changes in the dynamics of what will pass for scientific knowledge and expertise. All involved need to be aware of the social and legal construction of scientific knowledge and scientific expertise, as well as their fragility in sceptical legal contexts".

326. Marcelo BALICKI explica que "O pensamento complexo está ligado a uma pesquisa transdisciplinar e a um saber ambiental. A especificidade desses processos depende tanto das condições epistemológicas, que fundamentam sua apreensão cognitiva, como das condições políticas que levam a sua expressão na ordem do real. É, pois, uma questão de poder que atravessa as ciências e os saberes." A delimitação do Princípio da Precaução e o paradigma complexo de Edgar Morin. Revista de Direito Ambiental, v.12, n.48 (out./dez. 2007), p. 140-178, São Paulo: Revista dos Tribunais, 2007. 
com os padrões científicos apropriados.

Assim, dentro de certos limites regidos pela plausibilidade e probabilidade estatística, tenta-se buscar o máximo possível a certeza. Contudo, ao considerar-se que a ciência trabalha com elementos da natureza, e que essa é um sistema dinâmico, inúmeras consequências residem fora desse âmbito de previsibilidade. ${ }^{327}$ Há sempre um cenário incerto diante de consequências não racionalizáveis a priori.

Diante disso, nota-se que a incerteza, na sociedade contemporânea, emerge sob duplo aspecto: tanto com relação às dificuldades impostas pela complexidade (imprevisibilidade, multiplicidade, não linearidade) dos objetos de análise, como com relação ao conhecimento científico em si mesmo considerado (limitado). O reconhecimento dessas barreiras, no entanto, não deve autorizar o descrédito ou inutilidade da ciência, ao contrário, reafirma o seu valor fundamental e convida ao seu aprofundamento, a fim de controlar e gerenciar esses sistemas, tanto quanto possível.

Portanto, o uso do princípio da precaução não é um incentivo ao abandono de abordagens racionais trazidas pelos avanços tecnocientíficos, mas ao contrário, pugna por um aprofundamento da razão e o enfrentamento de complexidades com razoabilidade. ${ }^{328}$ Por outras palavras, a aplicação do referido princípio não justifica a inação na prevenção de riscos, e sim conduz a um processo de apoio à decisão, que deve ser utilizado quando não há informação suficiente sobre um possível efeito adverso que possa ocorrer no futuro, seguindo a difusão de conhecimento naquele momento estabelecida. Olivier Godard apresenta este entendimento, o que permite compreender o princípio da precaução como um princípio de ação:

327. Conclui-se que: "First of all, complex systems that can flip between multiple states and their accompanying non-linearity provide a special challenge to our ability to predict future states. There is an inherent uncertainty in these systems, an uncertainty that typically cannot be avoided by more research". World Commission on the Ethics of Scientific Knowledge and Technology (COMEST). The Precautionary Principle. France: UNESCO, 2005, p.26.

328. GRISON, Denis. Vers une philosophie de la precaution. Paris: L'Harmattan, 2009, p.56: "Nous devons apprendre à être raisonnables et pas seulement rationnels, à nous appuyer sur non émotions sans nous laisser aveugler par elles, à rentrer dans le débat argumentatif et à construire ensemble un "espace public des raisons". Il y faut de la rigueur mais aussi un esprit d'ouverture, de l'esprit de géométrie mais aussi de l'esprit de finesse, de l'humilité mais aussi de la confiance dans les puissances de la raison. La précaution ne nous demande certainement pas d'abandonner les démarches rationnelles; tout au contraire, c'est d'un approfondissement de la raison que nous avons besoin. Et, comme pour tout approfondissement, c'est a plus de complexité que nous devons nous affronter, c'est de plus de raison que nous avons besoin!" 
O que os autores chamam de 'efeito precaução' resulta da incidência, sobre o risco percebido ex ante, da perspectiva de melhoria da informação atribuída ao estado de incerteza científica inicial: uma incerteza científica é interpretada pelos autores como uma promessa de melhor conhecimento futuro, o que o distingue da álea pura. ${ }^{329}$

Uma outra faceta do princípio da precaução é constituir um incentivo para o desenvolvimento seguro, obrigando ao emprego da "melhor tecnologia disponível", 330 considerando-se os avanços dos processos, recursos ou métodos de operação que sinalizam mudanças no estado da arte. O governo brasileiro, por exemplo, seguindo uma tendência mundial, estabeleceu um calendário progressivo proibindo a venda de lâmpadas incandescentes no país até junho de $2017,{ }^{331}$ substituindo essa tecnologia pela utilizada em lâmpadas fluorescentes, consideradas mais eficientes. Demonstração clara de atuação preventiva com relação ao desenvolvimento sustentável.

A identificação do princípio da precaução como uma exigência de ação antes que a certeza sobre a possibilidade de danos possa ser cientificamente estabelecida, conduz ao questionamento sobre quais são os elementos que autorizam o uso do princípio para a restrição de uma atividade, e até qual momento o mesmo será imposto.

A utilização do princípio da precaução implica sempre uma escolha por valores sociais especialmente protegidos, em consideração à saúde pública e proteção ambiental, que em hipóteses de conflito com aspectos econômicos, devem ter precedência.

Quando se trata de efeitos irreversíveis e de grande repercussão, ainda que a comunidade científica não tenha uma conclusão acerca de um aspecto específico da atividade, porém, o risco é avaliado como potencial, será a possível gravidade dos efeitos que o limiar necessário para o acionamento do princípio da precaução.

Em outras palavras, é a plausibilidade do risco aliada à dimensão do dano que vai impulsionar, de forma proporcional, a imposição de medidas, como o estabelecimento de um programa de pesquisa mais aprofundado ou até mesmo a suspensão

329. Le principe de précaution comme norme de l'action publique, ou la proportionnalité en question. Revue économique. Vol. 54, N 6, p.1245-1276, novembre 2003, p.1271.

330. WOLFRUM, Rüdiger. O princípio da precaução. In: VARELLA, Marcelo Dias; PLATIAU, Ana Flávia Barros (Org.). Princípio da precaução. Belo Horizonte: Del Rey, 2004, p.21.

331. Ministério de Minas e Energia, Portaria n 1007, de 31 de dezembro de 2010. 
da atividade, até que seja restabelecida a confiança na operação interrompida, em função da responsabilidade perante a coletividade.

Portanto, o princípio da precaução não se coaduna com a inação, não se trata de pregar autoritariamente uma ciência não aprofundada que anuncia uma "verdade absoluta". Sob esse aspecto, com realce à importância da proporcionalidade para a aplicação do princípio da precaução, Olivier Godard:

O Princípio da Precaução não consiste em procurar alcançar assintomaticamente um estado de risco potencial através da promoção de "precauções máximas". Seu objetivo não pode ser o de fazer de tudo para evitar de forma absoluta a realização de dano potencial, mesmo graves e irreversíveis, mesmo apocalíptico. A sua ideia diretriz é o da prevenção precoce, porém proporcional, de riscos potenciais. Todas as hipóteses de risco não podem ser consideradas como igualmente válidas. Uma das tarefas essenciais dos comités de peritos científicos é julgar a plausibilidade ou consistência científica de hipóteses de riscos com base em uma escala relevante para a ação pública. ${ }^{332}$

Essa plausibilidade poderá ser identificada através de critérios de evidência, expostos por Alan Randall. ${ }^{333}$ Em primeiro lugar, a evidência que justifique a interrupção cautelar de um negócio, naturalmente, deve ser científica e verossímil, devendo ser afastado o "catastrofismo" infundado. As evidências devem ser científicas, acerca das

332. Le principe de précaution comme norme de l'action publique, ou la proportionnalité en question. Revue économique. Vol. 54, $\mathrm{N}^{\circ}$ 6, p.1245-1276, novembre 2003, p.1274. Tradução livre. Em língua original: "Le PP ne consiste pas à rechercher à atteindre asymptotiquement un état de risque potentiel zéro en promouvant un «maximum de précautions ». Son objectif ne peut pas être de tout faire pour empêcher absolument la réalisation d'un dommage potentiel, même grave et irréversible, même apocalyptique. Son idée directrice est celle d'une prévention précoce, mais proportionnée, des risques potentiels. Toutes les hypothèses de risque ne peuvent pas être considérées comme également valides. Une des tâches essentielles des comités d'experts scientifiques consiste à juger de la plausibilité ou de la consistance scientifique des hypothèses de risques en fonction d'une graduation pertinente pour l'action publique"

333. Risk and precaution. Cambridge: Cambridge University Press, 2011, p.105. Em língua original: "First, the evidence that would justify a precautionary interruption of business as usual should be scientific and credible - one cannot take seriously a PP that can be triggered by unfounded panic. The evidence underpinning decisions should reflect accurately what is broadly accepted in the scientific community, what controversies remanin active and why, and what remains uncertain or unknown. Second, science and the institutions that support it should have adequate defenses against distortions (including inflated threat- claims that may induce unfounded panic, and unwarranted insistence that there is nothing to worry about) and the cynical exploitation of cognitive biases in service of various interests. The third issue is, giver scientific uncertainty, how much credible evidence of threat is enough to trigger a precautionary response? We should perhaps entertain the prospect that the acceptable amount and quality of evidence might logically be related to the magnitude of potential harm. We may take precautions against catastrophic harm een when we are quite unsure if it might be experienced in the default (without precautions) case." 
controvérsias que permanecem presentes e os seus motivos, bem como o que permanece incerto ou desconhecido. Em segundo lugar, há de se estabelecer defesas contra distorções infundadas capazes de gerar pânico, ou ainda, contra exploração "cínica” de correntes de conhecimento a serviço de interesses diversos. A terceira questão diz respeito ao momento de aplicação da precaução, o que está estreitamente relacionado com a magnitude do dano potencial. Assim, é necessário tomar medidas de precaução contra danos em larga escala mesmo se houver relativa insegurança quanto à sua efetiva e possível ocorrência.

Destas considerações, denota-se que a regulamentação mais ou menos rígida acerca das atividades de risco, como a utilização de determinadas tecnologias ou produtos, deve ser avaliada a partir da proporcionalidade atribuída aos seus efeitos positivos e negativos. Essa sensibilidade não é estranha aos tribunais brasileiros, quando, por exemplo, o Superior Tribunal de Justiça, valendo-se da proporcionalidade, julgou questão atinente ao uso da precaução e a permissão do uso do fogo no processo produtivo agrícola. ${ }^{334}$

334. Brasil - Superior Tribunal de Justiça - T2 - SEGUNDA TURMA - REsp: 1285463 SP 2011/0190433-2 - Relator: Ministro HUMBERTO MARTINS - Data de Julgamento: 28/02/2012 - Data de Publicação: DJe 06/03/2012 - Ementa: "DIREITO AMBIENTAL. AÇÃO CIVIL PÚBLICA. CANA-DEAÇÚCAR. QUEIMADAS. ART. 21, PARÁGRAFO ÚNICO, DA LEI N. 4771/65. DANO AO MEIO AMBIENTE. PRINCÍPIO DA PRECAUÇÃO. QUEIMA DA PALHA DE CANA. EXISTÊNCIA DE REGRA EXPRESSA PROIBITIVA. EXCEÇÃO EXISTENTE SOMENTE PARA PRESERVAR PECULIARIDADES LOCAIS OU REGIONAIS RELACIONADAS À IDENTIDADE CULTURAL. INAPLICABILIDADE ÀS ATIVIDADES AGRÍCOLAS INDUSTRIAIS. 1. O princípio da precaução, consagrado formalmente pela Conferência das Nações Unidas sobre o Meio Ambiente e o Desenvolvimento - Rio 92 (ratificada pelo Brasil), a ausência de certezas científicas não pode ser argumento utilizado para postergar a adoção de medidas eficazes para a proteção ambiental. Na dúvida, prevalece a defesa do meio ambiente. 2. A situação de tensão entre princípios deve ser resolvida pela ponderação, fundamentada e racional, entre os valores conflitantes. Em face dos princípios democráticos e da Separação dos Poderes, é o Poder Legislativo quem possui a primazia no processo de ponderação, de modo que o Judiciário deve intervir apenas no caso de ausência ou desproporcionalidade da opção adotada pelo legislador. 3. O legislador brasileiro, atento a essa questão, disciplinou o uso do fogo no processo produtivo agrícola, quando prescreveu no art. 27, parágrafo único da Lei n. 4.771/65 que o Poder Público poderia autoriza-lo em práticas agropastoris ou florestais desde que em razão de peculiaridades locais ou regionais. 4. Buscou-se, com isso, compatibilizar dois valores protegidos na Constituição Federal de 1988, quais sejam, o meio ambiente e a cultura ou o modo de fazer, este quando necessário à sobrevivência dos pequenos produtores que retiram seu sustento da atividade agrícola e que não dispõem de outros métodos para o exercício desta, que não o uso do fogo. 5. A interpretação do art. 27, parágrafo único do Código Florestal não pode conduzir ao entendimento de que estão por ele abrangidas as atividades agroindustriais ou agrícolas organizadas, ou seja, exercidas empresarialmente, pois dispõe de condições financeiras para implantar outros métodos menos ofensivos ao meio ambiente. Precedente: (AgRg nos EDcl no REsp 1094873/SP, Rel. Min. HumbertoMartins, Segunda Turma, julgado em 04/08/2009, DJe 17/08/2009). 6. Ademais, ainda que se entenda que é possível à administração pública autorizar a queima da palha da cana de açúcar em atividades agrícolas industriais, a permissão deve ser específica, precedida de estudo de impacto ambiental e licenciamento, com a implementação de medidas que viabilizem amenizar os danos e a recuperar o ambiente. Tudo isso em respeito ao art. 10 da Lei n. 6.938/81. Precedente:(EREsp 418.565/SP, Rel. Min. Teori Albino Zavascki, Primeira Seção,julgado em 29/09/2010, DJe 
O fundamento constitucional do princípio da proporcionalidade pode ser extraído implicitamente da Constituição Federal, como um princípio não escrito inerente ao Estado de Direito. Por influência alemã - em especial a teoria estrutural de Robert Alexy e o juízo de ponderação, ${ }^{335}$ reconhece-se que o princípio da proporcionalidade é composto por três subprincípios, que constituem expressão da ideia de "mandamentos de otimização". O primeiro - da adequação, exige o estudo da relação meio-fim, constatandose a existência de uma finalidade instituída na Constituição que possa justificar a restrição de um direito. O segundo - da indispensabilidade, preconiza que devem ser afastadas todas as alternativas que resultem mais gravosas para o direito fundamental afetado. Por fim - da proporcionalidade em sentido estrito, os meios eleitos devem ser adotados no limite adequado (razoável) ao benefício que o resultado gera para a coletividade. ${ }^{336}$ Assim, no que concerne à aplicação do princípio da precaução como fundamento para a restrição dos princípios gerais da atividade econômica, insertos no art. 170 da Constituição Federal, a decisão judicial deverá realizar um balanceamento axiológico com o objetivo de chegar a uma diretiva segura, com aplicação adequada do componente valorativo na interpretação da norma. ${ }^{337}$

Não é apenas a doutrina constitucionalista que oferece soluções para a hipótese de colisão de direitos. ${ }^{338}$ Com efeito, a experiência portuguesa exposta por António Menezes Cordeiro, apresenta um relevante quadro de soluções, com apoio em Corrêa Teles e Coelho da Rocha:

16. Se o direito de um se encontra com o exercício do direito de outro, o direito menor deve

13/10/2010). Recurso especial provido.”

335. ALEXY, Robert. Constitucionalismo discursivo. Trad. Luís Afonso Heck. 2. ed. Porto Alegre: Livraria do Advogado Editora, 2008, p.156: “A ponderação desempenha, na prática atual de muitos tribunais constitucionais, um papel central [...]. Ele pode ser formulado na regra seguinte: Quanto maior é o grau de não-cumprimento ou prejuízo de um princípio, tanto maior deve ser a importância do cumprimento do outro. Essa regra pode ser designada como 'lei da ponderação"”.

336. NETO, João Pedro Gebran. A aplicação imediata dos direitos e garantias fundamentais: a busca de uma exegese emancipatória. São Paulo: Editora Revista dos Tribunais, 2002, p.113-117.

337. LARENZ, Karl. Metodologia da ciência do direito. Trad. José Lamego. 3 ed. Lisboa: Fundação Calouste Gulbenkian, 1997, p.300.

338. "Trata-se de um termo técnico, cujo afinamento remonta aos clássicos Thibaut e Mackeldey, e que devemos ter como pressuposto. Há colisão, em sentido próprio e como foi adiantado, quando dois ou mais direitos subjetivos assegurem, aos seus titulares, permissões incompatíveis entre si. A colisão de direitos pressupõe, deste modo, um concurso real de normas". MENEZES CORDEIRO, Antônio. Tratado de Direito Civil V. Parte Geral. Exercício Jurídico. Coimbra: Almedina, 2011, p.385. 
ceder ao maior. 17. Em paridade de direitos, o primeiro em tempo é primeiro em direito. 18. Se for desconhecida a prioridade do tempo, aquele que menos sofre deve ceder ao outro, que sofreria mais. 19. Assim aquele que trata de captar lucro, deve ceder àquele, que trata de conseguir a sua indemnização. 20. Sendo possível usarem ambos do seu direito, cedendo cada um uma parte d'ele, cada qual deve ceder o bastante, para usarem ao mesmo tempo. 21. O direito maior e mais extenso encerra em si o menor, e mais limitado [...] $5^{\mathrm{a}} \mathrm{Na}$ colisão dos direitos prefere o maior, isto é, o mais favorecido pelas leis; $6^{\text {a }}$ Se são igualmente favorecidos, aquelle que tem por fim evitar um dano, deve preferir áquele que tracta de obter um [benefício]; $7^{\mathrm{a}} \mathrm{Se}$ os direitos são perfeitamente iguais, deve cada um ceder em parte, quando seja necessário, para que ambos o exercitem.

A aplicação do princípio da proporcionalidade para orientar uma decisão razoável acerca da imposição de medida precautória faz-se importante, sobretudo, para evitar a "avaliação heurística"339 que atribui importância desigual aos riscos de acordo com a percepção e proximidade que se mantém em relação ao mesmo, bem como evita o "efeito paralisante" que a aplicação excessiva do princípio da precaução poderia acarretar, e justamente neste argumento reside a sua maior crítica, exposta por Cass Sustain:

Eu não afirmo que precauções são um equívoco, ou mesmo que é impossível reconstruir o Princípio da Precaução em fundamentos sensíveis. Por enquanto, o meu único lamento é que este princípio é uma bruta, e às vezes perversa maneira de promover objetivos desejáveis - e que se isso for considerado para tudo aquilo que vale a pena, ele é paralisante, e portanto, inútil. ${ }^{340}$

Na evolução do pensamento do professor norte-americano, o mesmo destaca que, embora por ele considerada inútil, o uso frequente da precaução como fonte de orientação pode ser explicado por mecanismos cognitivos identificados por economistas comportamentais, como a aversão à perda, a disponibilidade heurística, probabilidades negligenciadas e indiferença quanto aos efeitos sistêmicos (system neglect) da regulação. ${ }^{341}$

339. SUSTEIN, Cass R. Laws of fear: beyond the precautionary principle. Cambridge: Cambridge University Press, 2005, p.36: "The availability heuristic illuminates the operation of the Precautionary Principle, by showing why some hazards will be on-screen and why others will be neglected".

340. SUSTEIN, Cass R., op.cit., p.34. No original: "I do not contend that precautions are a mistake, or even that it is impossible to reconstruct the Precautionary Principle on sensible foundations. For now, my only claim is that the principle is a crude and sometimes perverse way of promoting desirable goals and that if it is taken for all that it is worth, it is paralyzing, and therefore not helpful at all."

341. SUSTEIN, Cass R. Para além do Princípio a Precaução. Tradução de Letícia Garcia Ribeiro. Revista de Direito Administrativo, Rio de Janeiro, v. 259, p.11-71, jan./abr. 2012, p.12. 
A partir dos elementos acima indicados, se a autoridade concluir pela restrição de determinada atividade por imposição da medida precautória, as hipóteses científicas devem ser submetidas a um processo de avaliação contínua para a seleção e determinação daquela que for mais adequada para o controle dos riscos. Ou seja, além do princípio da proporcionalidade, ${ }^{342}$ os múltiplos interesses em jogo são salvaguardados por uma série de outros princípios, concernentes à gestão do risco: não discriminação, coerência, análise de benefícios e custos da ação e omissão, revisão das medidas à luz de novos conhecimentos científicos e por fim, que tais medidas sejam capazes de designar a quem incumbe apresentar as provas científicas necessárias para uma avaliação do risco mais completa.

O Princípio ALARA (As low as reasonably achievable), bem como o ALATA (As low as technics achievable), também são estratégias utilizadas para a gestão de riscos, no sentido, respectivamente, de manter as exposições aos riscos tão baixas quanto razoavelmente seja possível, ou tão baixa quanto tecnicamente possível. O primeiro é utilizado no contexto de proteção contra a radiação, e o segundo foi reconhecido na Bundesimmissionschutzgesetz alemã de 1974, em seu art. 5.1.2, que fazia referência à limitação de emissões conforme a melhor tecnologia disponível. ${ }^{343}$

No Brasil, não há uma regulamentação de riscos geral estipulando critérios relacionados precisamente à sua avaliação e gestão. No entanto, respeitando as especificidades de cada atividade, existem normativas direcionadas, previstas em leis especiais e respectivos regulamentos, a exemplo das ilustrações abaixo.

Assim, com este propósito, a Lei de Biossegurança (Lei n. 11.105/05) transfere a função de avaliação de riscos (risk assessment) ao "parecer técnico favorável da CTNBio" (art. 60, VI). Já a Lei de Política Nacional de Resíduos Sólidos (Lei n. 12.305/10), estabelece no art. $9^{\circ}$ uma ordem de prioridade na gestão e gerenciamento de resíduos (risk management): "geração, redução, reutilização, reciclagem, tratamento dos resíduos sólidos e disposição final ambientalmente adequada dos rejeitos”. E a seu turno, a

342. Conseil Européen. Reunión de Nice. 7-9 déc 2000. Annexe III. Résolution sur le Principe de Précaution. Disponível em <http://www.europarl.europa.eu/summits/nice2_fr.htm>. Acesso em: 25 set. 2013.

343. TELLO, Antonio Eduardo Embid. Precaución y derecho: el caso de los campos electromagnéticos. Madrid: Iustel, 2010, p.241. 
Lei de Política Nacional de Proteção e Defesa Civil (Lei n. 12.608/12), determina a criação de mecanismos facilitadores para a divulgação de riscos de desastres (risk communication), em ambiente informatizado, que atuará por meio de base de dados compartilhada visando ao oferecimento de informações para prevenção, mitigação, alerta, resposta e recuperação em todo o território nacional.

De acordo com as legislações acima mencionadas, é possível estabelecer três fases concernentes ao gerenciamento dos riscos (embora uma ou outra etapa receba maior ou menor destaque nas respectivas áreas); avaliação (risk assessment), gestão (risk management) e informação (risk communication).

A primeira fase é a da avaliação do risco (risk assessment). Esta pode ser quantitativa, onde a ênfase reside na expressão numérica dos resultados, ou qualitativa, em consideração à percepção social do risco e suas repercussões econômicas. O seu desenvolvimento ocorre em três momentos sequenciais: a) identificação de potenciais resultados; b) estimação sobre a magnitude desses resultados; c) probabilidade de realização desses resultados. ${ }^{344} \mathrm{Na}$ segunda fase, de gestão dos riscos (risk management), os resultados da avaliação são considerados para amparar a decisão sobre as medidas adequadas para o específico risco. Trata-se de um conjunto de ações baseadas em informações necessárias para a legitimação da decisão, tais como: dados científicos obtidos na avaliação dos riscos (toxicologia, epidemiologia, estatísticas etc.); fatores econômicos indicativos do custo dos riscos e os benefícios de reduzi-lo, os custos da prevenção e a distribuição de efeitos; considerações legais acerca de normas que estabelecem forma, intensidade e métodos para a redução dos riscos; fatores sociais dos indivíduos ou grupos afetados pelos riscos, como valores, estado de saúde, estilo de vida, etnia, local em que habita, condições psicológicas etc.; fatores tecnológicos que incluem a viabilidade, impactos e variedade de opções de gestão de risco; fatores políticos internos e externos ao país; valores sociais acerca dos riscos ambientais e sanitários. ${ }^{345} \mathrm{~A}$ terceira fase é a da comunicação dos riscos avaliados (risk communication). Joakim Zander ${ }^{346}$ observa que o

344. ZANDER, Joakim. The application of the Precautionary Principle in Practice: comparative dimensions. Cambridge: Cambridge University Press, 2010, p.17.

345. RANDALL, Alan. Risk and precaution. Cambridge: Cambridge University Press, 2011, p.53-54.

346. The application of the Precautionary Principle in Practice: comparative dimensions. Cambridge: Cambridge University Press, 2010, p.20. 
interesse na comunicação dos riscos aumentou significativamente nos últimos anos, o que pode ser justificado, por um lado, pela ampliação de leis que prestigiam a transparência, a confiança e o direito à informação, mas sobretudo, em razão da "food scares" e consequentemente, da ampliação de interesse sobre as questões ambientais e sanitárias pelos meios de comunicação e sociedade em geral. Por sua vez, quanto mais preocupada a sociedade se torna, mais ela influencia a gestão de riscos, ao exigir respostas claras com relação à magnitude e a probabilidade da ocorrência de danos.

No ordenamento jurídico brasileiro, de fato, a exigência legal de informações claras, extensivas e compreensíveis a respeito dos riscos apresentados pelos serviços ou produtos inseridos no mercado do consumo é bastante exigente, posto que decorre do dever de segurança que fundamenta a Responsabilidade Civil Preventiva. A análise e a extensão imposta por este direito e dever de informação, serão abordados em momento próprio, na segunda parte dessa pesquisa.

Importante realçar, neste ponto, que não se desconhece que de acordo com diferentes culturas e estratégias políticas, o modo empregado ao gerenciamento dos riscos e aplicação do princípio da precaução pode ser bastante variável, alternando posições mais ou menos rígidas, o que se afigura nítido quando se efetua um comparativo, por exemplo, entre a União Europeia e os Estados Unidos, além da Organização Mundial do Comércio (OMC) e Corte Internacional de Justiça. ${ }^{347}$ Contudo, a identificação de um procedimento para o gerenciamento de riscos que faça a distinção das diferenciadas fases é importante para submetê-lo a um monitoramento jurídico, e fornecer elementos ao magistrado para que possa, diante da realidade, decidir em que momento a situação específica deverá estar ou não acobertada por medidas precautórias ou preventivas, bem como efetuar um controle de proporcionalidade das mesmas. Excelente exemplo é dado por Christine Noiville, referindo-se à repercussão na Europa do caso Pfizer:

[...] o controle da proporcionalidade se deu em quatro etapas: em primeiro lugar, o juiz verificou se a proibição de utilização de certos antibióticos na criação de rebanhos ia ao encontro do objetivo perseguido no caso; em segundo, se medidas alternativas menos restritivas não poderiam ser tomadas; em terceiro - análise menos frequente - se os

347. Para aprofundamento: VARELLA, Marcelo Dias. Variações sobre um mesmo tema: o exemplo da implementação do Princípio da Precaução pela CIJ, OMC, CJCE e EUA. In: VARELLA, Marcelo Dias; PLATIAU, Ana Flávia Barros (Org.). Princípio da precaução. Belo Horizonte: Del Rey, 2004, p.274-295. 
inconvenientes causados por essas medidas não eram descomedidos em relação ao objetivo desejado; e finalmente - situação ainda mais rara - se na análise da relação custo/benefício os inconvenientes não seriam excessivos em relação às vantagens decorrentes de uma inação. Passo a passo, o juiz abordou essas diferentes etapas, analisando se a utilização de antibióticos como fator de crescimento seria indispensável ou não para a produção da carne. $^{348}$

Resta claro que a avaliação das condições sobre a aceitabilidade do risco e o seu gerenciamento não é somente tarefa do governo na definição do interesse público. Cabe a todos os operadores do Direito e ao Poder Judiciário, em especial, a tarefa de modular, através de instrumentos normativos - notadamente os princípios da precaução e da prevenção e a responsabilidade civil - a delimitação dessa escolha, informado pelos valores mais altos consagrados no sistema jurídico. Dúvida não há de que a incerteza científica constitui um desafio não apenas para a ciência e o gerenciamento dos riscos, mas também para a legitimidade das ações e políticas públicas. Ao tempo do Welfare State, as decisões eram modeladas sobre a base de um modelo legal racional, com objetividade estabelecida de acordo com o interesse social, confiança e apoio da opinião pública. Contudo, diante da incerteza, os agentes públicos lidam com possibilidades, informações fragmentadas e valores sociais (especialmente a segurança) - o risco levaria a uma catástrofe? Imaginem-se hipóteses de campanhas de vacinação em massa, combate a insetos transmissores de vírus infecciosos, prevenção de desastres provocados por fatores ambientais como chuvas intensas (e seus derivados, como impermeabilização do solo, drenagem deficiente e enchentes, destino do lixo, leptospirose, ocupação irregular do solo em regiões não atingidas, danos materiais diversos, perda de vidas, trânsito caótico nas cidades). Ou ainda, liberação de produtos tóxicos no mercado, medicamentos, contaminação de lavouras.

Todos esses fatos implicam uma decisão. Para auxiliar o controle e gestão de riscos, são desenvolvidos instrumentos de atuação para a instituição de deveres prévios e observância de padrões mínimos de segurança, ${ }^{349}$ o que ocorre através de normas legais

348. Ciência, decisão e ação: três observações em torno do princípio da precaução. VARELLA, Marcelo Dias (Org.). Governo dos riscos. Brasília: UNICEUB e UNITAR, 2005, p.44.

349. No mesmo sentido: SCHREIBER, Anderson. Novos paradigmas da responsabilidade civil: da erosão dos filtros da reparação à diluição dos danos. São Paulo: Atlas, 2007, p.217 e LEVY, Daniel de Andrade. Responsabilidade civil: de um direito dos danos a um direito das condutas lesivas. São Paulo: Atlas, 2012, p.137. 
ou regulamentadoras, e sua respectiva fiscalização por órgãos designados a cada setor. Nesse desiderato, no Brasil, podemos citar, entre outras, as atribuições exercidas pelo IBAMA - Instituto Brasileiro do Meio Ambiente e dos Recursos Naturais Renováveis, no cumprimento de seus objetivos institucionais relativos ao licenciamento ambiental, ao controle da qualidade ambiental, à autorização de uso dos recursos naturais e à fiscalização, monitoramento e controle ambiental; a CTNBio - Comissão Técnica Nacional de Biossegurança, cuja finalidade é prestar apoio técnico consultivo e assessoramento ao Governo Federal na formulação, atualização e implementação da Política Nacional de Biossegurança relativa a OGM; bem como as Agências Reguladoras, criadas com o objetivo de físcalizar a prestação de serviços públicos praticados pela iniciativa privada, com o compromisso de controlar a qualidade na prestação do serviço, estabelecendo regras às específicas atividades de produção, proteger o interesse da coletividade consumidora, bem como promover a sua eficiente fiscalização, com escopo preventivo de danos.

$\mathrm{Na}$ esfera federal, é exemplo de agência reguladora com expressiva atuação no controle de riscos incertos, a ANVISA (Agência Nacional de Vigilância Sanitária), ao realizar o controle sanitário da produção e comercialização de produtos como medicamentos e agrotóxicos, com expressivo reconhecimento do Poder Judiciário em relação ao seu poder de polícia amparado no princípio da precaução, consoante se depreende da decisão do Tribunal Regional Federal da $1^{\text {a }}$ Região, ${ }^{350}$ com referência à

350. Brasil - TRF-1 - Quinta Turma - AG: 42663 DF 0042663-13.2011.4.01.0000, Relator Desembargador Federal Souza Prudente, Data de Julgamento: 15/08/2012, Data de Publicação: e-DJF1 p.1219 de 22/08/2012. Ementa: "CONSTITUCIONAL E ADMINISTRATIVO. ANVISA. REAVALIAÇÃO DO REGISTRO DE PRODUTO AGROTÓXICO (INGREDIENTE ATIVO METAMIDOFÓS). PRINCÍPIO DA PRECAUÇÃO. PODER DE POLÍCIA DA AGÊNCIA NACIONAL DE VIGILÂNCIA SANITÁRIA. LEGALIDADE. I - Se a Constituição da Republica Federativa do Brasil, no âmbito normativo da tutela cautelar do Meio Ambiente, impõe ao Poder Público e à coletividade o dever de "controlar a produção, a comercialização e o emprego de técnicas, métodos e substâncias que comportem risco para a vida, a qualidade de vida e o meio ambiente" (CF, art. $225, \S 1^{\circ}$, V), enquanto a Lei $\mathrm{n}^{\mathrm{O}}$ 6.938, de 31 de agosto de 1981, ao dispor sobre a Política Nacional do Meio Ambiente, tem, como objetivo principal, a preservação, melhoria e recuperação da qualidade ambiental propícia à vida (art. $2^{\circ}$, caput), há de se entender porque as atividades relativas à produção e comercialização de produtos agrotóxicos, como na espécie dos autos, não poderão deixar de submeter-se ao atuar legítimo do Poder de Polícia da ANVISA. II - Em casos que tais, a presença de indícios dos efeitos maléficos que o referido produto possa causar ao consumidor autoriza a adoção das medidas necessárias, visando a inibição de riscos à sua saúde e qualidade de vida, em homenagem ao princípio da precaução, que, na defesa do interesse sanitário-difuso, haverá sempre de se sobrepor a qualquer outro, mormente quando de cunho eminentemente material, como no caso dos autos, p civilegiando-se, assim, a garantia do direito à saúde e à vida, a que todos fazem jus, nos termos de nossa Constituição Federal. III - Agravo de instrumento provido." 
avaliação de produtos agrotóxicos para respectiva liberação e registro.

Igual legitimidade é conferida à ANAC (Agência Nacional de Aviação Civil), ao regular e fiscalizar as atividades do setor para garantir a segurança do transporte aéreo e prevenção de acidentes, como pode ser verificado no reconhecimento judicial conferido pelo Tribunal Regional Federal da $1^{\mathrm{a}}$ Região, relativo à exigência de instalação de equipamentos de segurança. ${ }^{351}$

Ocorre que a autoridade (agências reguladoras, comitês científicos etc.) designada para avaliar e adotar medidas de precaução, conta com uma ampla margem de apreciação no momento de decidir acerca da pertinência ou não de sua aplicação. No campo da dúvida, a discricionariedade administrativa abre a possibilidade de se questionar a responsabilidade por omissão do poder público, ante os riscos incertos. Disso decorre a verificação sobre quais são os limites do Poder Judiciário no sentido de controlar o exercício desse poder-dever, o que equivale a dizer, a oportunidade e a conveniência dos mesmos.

A questão torna-se relevante, sob pena de negar qualquer aplicação jurídica concreta ao princípio da precaução, especialmente com relação aos órgãos encarregados da

351. Brasil - TRF-1 - Quinta Turma - AGA: 40277 DF 2008.01.00.040277-1, Relator Desembargador Federal João Batista Moreira, Data de Julgamento: 29/10/2008, Data de Publicação: 13/02/2009 eDJF1 p.583. Ementa: "ADMINISTRATIVO. AGRAVO REGIMENTAL/INTERNO. AGRAVO DE INSTRUMENTO. TRANSPORTE AÉREO. EXIGÊNCIA DE SEGURANÇA IMPOSTA PELA ANAC. LEGITIMIDADE. 1. Desde 28 de janeiro de 2005, é obrigatória a instalação de um sistema embarcado de prevenção de colisões ACAS II ou TCAS II tipo 7.0 para qualquer grande avião com motores a turbina que tenha uma configuração para passageiros com mais de 30 assentos, excluindo qualquer assento para tripulante, independentemente da utilização atual da aeronave: transporte de passageiros ou de cargas (item 121.356 da RBHA 121/2005). 2. A aeronave PT-MTC, por se tratar de um 727-200, se trata de um grande avião como motores a turbina e que tem uma configuração de passageiros com mais de 30 assentos, excluindo qualquer assento para tripulante. 3. Diante do longo tempo transcorrido desde o estabelecimento da exigência questionada (28 de janeiro de 2005), não há que se falar em exigüidade do prazo recentemente concedido para a comprovação da instalação do equipamento, assim considerado o dia 4 de agosto de 2008 (art. $1^{\circ}$, Resolução n. 35/2008). 4. Não há direito adquirido de não se submeter e/ou continuar descumprindo exigência legítima atinente à segurança no transporte aéreo. 5. O mero fato de a ANAC ter demorado a exigir o cumprimento da obrigação especificamente quanto à aeronave em testilha não confere à agravante o direito de postergar, ainda mais, o cumprimento de tal exigência. 6. O prazo maior concedido para a comprovação da instalação do sistema ACAS II ou TCAS II, tipo 7.0 (art. 2º Resolução 35/2008), relativamente às aeronaves que já disponham do TCAS I, certamente se justifica pelo fato de se reconhecer alguma eficácia a esse dispositivo de prevenção de colisão. Consequentemente, não há que se falar em violação da isonomia e/ou da razoabilidade, pois o critério de diferenciação afigura-se proporcional, partindo do pressuposto de que se pretende aumentar gradativamente a segurança no transporte aéreo. 7. Não havendo ilegitimidade manifesta na exigência impugnada, o princípio da precaução impõe que ela seja mantida, objetivando evitar a consumação de acidentes aéreos. 8. Agravo regimental/interno não provido." 
avaliação do risco (risk assessment), diante das fragilidades apontadas por Antonio Eduardo Embid Tello:

En primer lugar, porque es en el seno de dicho Comité donde reside la decisión más importante, con mucho, de todo el processo de adopción de medidas precautórias. En segundo lugar, porque dicha decisión, al versar sobre una materia no del todo comprensible para la ciencia, corre un peligro 'extra' de hundir sus raíces en cimientos subjetivos, al ser adoptada por alguien 'materialmente incompetente' para ello (la ciencia no ha reconocido todavia una certeza al respecto, luego de momento 'ha fracasado'). En tercer lugar, porque la evaluación del riesgo, al ser llevada a cabo por instituciones científicas con un grado de control democrático invariablemente inferior al de las instituciones democráticas, y al versar sobre materias inciertas difícilmente discutibles, es fácilmente manipulable por intereses políticos o económicos, que preferirán siempre que el posible riesgo que generan se repute inexistente a litigar más adelante sobre la proporcionalidad de las medidas que contra sus intereses se adopte. ${ }^{352}$

No Brasil, por exemplo, a problemática da competência absoluta da comissão científica com relação à avaliação dos riscos incertos foi objeto de questionamento no divulgado caso da soja "Roundup Ready", especificamente com relação à CTNBio, posto que a introdução de culturas transgênicas na agricultura ainda hoje gera várias dúvidas.

Uma breve referência aos fatos poderá relacionar a questão ao tema ora tratado. Pois bem.

A primeira e grande discussão envolvendo a questão da liberação dos alimentos modificados geneticamente - o estudo prévio de impacto ambiental ocorreu sob a vigência da Lei 8975/95, que regulamentou os incisos II e IV do $§ 1^{\circ}$ do art. 225 da $\mathrm{CF} / 88$. Referida lei estabeleceu normas para o uso das técnicas de engenharia genética e liberaçao no meio ambiente de OGM e autorizou a criação da Comissão Técnica Nacional de Biossegurança (CTNBio). Por sua vez, foi o Decreto 1752/95, que regulamentou a lei, que conferiu a efetiva criação da CTNBio. Essas normas já determinavam a obrigatoriedade de que toda atividade relacionada à OGMs dentro do país precisaria ser previamente aprovada, e todo produto contendo OGM (importação, comércio, transporte, armazenamento, manipulação, consumo, liberação e descarte) deveria observar as 
instruções normativas da CTNBio.

No contexto deste manancial legislativo é que houve o primeiro pedido para uso em escala comercial de um OGM (até então os pedidos se destinavam ao cultivo em caráter experimental), a soja "Roundup Ready”. Pela redação da Lei 8975/95 e Decreto 1752/95, a CTNBio seria competente para emitir parecer técnico conclusivo sobre qualquer liberação de OGM no meio ambiente. Referidas normas não se referiam especificamente ao estudo prévio de impacto ambiental, como determina a CF/88 para as ações consideradas de risco ao meio ambiente (consagrando o princípio da precaução a reger o Direito ambiental).

Ocorre que ao emitir as suas instruções normativas, a CTNBio entendeu ser responsável pelo requerimento do estudo de impacto ambiental apenas quando e se reconhecesse a necessidade no caso concreto. Por sua vez, não reconhecida a necessidade, o parecer técnico realizado por sua Comissão ad hoc seria suficiente, conclusivo e vinculatório para a liberação do OGM no meio ambiente. Desse modo, em 1998, foi liberada a soja da empresa Monsanto, sem a realização do estudo prévio de impacto ambiental. Argumenta-se que além de ter extrapolado a sua competência, a CTNBio violou também o princípio da publicidade e o princípio democrático, ${ }^{353}$ pois não havia sido realizada qualquer audiência pública antes da tomada de decisão normativa que implique interesses gerais, como é o caso de alimentos transgênicos.

Tal liberação motivou o IDEC, Greenpeace e Ibama a ajuizarem ação (Medida Liminar, seguida de Cautelar Inominada e posteriormente Ação Civil Pública) contra a União e as empresas Monsanto e Monsoy Ltda., requerendo a suspensão da liberação comercial da soja RR até a conclusão de estudos sobre sua segurança. O argumento utilizado pela CTNBio foi o de que a soja RR já havia sido testada em outro país, no caso, os Estados Unidos, sem sinais de insegurança, o que dispensaria o estudo prévio de impacto ambiental, pois a segurança foi atestada por meio de documentos entregues à Comissão pela própria empresa interessada. Note-se que o parecer da CTNBio não autorizou o plantio da soja, o que seria competência do Ministério da Agricultura,

353. Neste sentido, Sílvia Helena Serra. Caso Soja Roundup Ready: a violação do princípio democrático e do princípio da publicidade pela CTNBio. In: Derani, Cristiane (Org.). Transgênicos no Brasil e Biossegurança. Porto Alegre: Sérgio Antônio Fabris Editora, 2005, p.157. 
contudo, autorizou sem o estudo determinado na Constituição Federal a liberação do produto. A situação ganhou repercussão nacional em todas as instâncias da sociedade. $\mathrm{O}$ desfecho da questão é conhecido nacionalmente: a ação civil pública foi julgada procedente em $1^{\mathrm{a}}$ instância, e posteriormente, após longa tramitação no Tribunal Regional Federal da $1^{\mathrm{a}}$ região foi dado provimento, por maioria de votos da Turma Julgadora, ao recurso de apelação da Monsanto, para o fim de afastar a exigência da realização de estudo de impacto ambiental e liberar o comércio da soja transgênica. Em junho de 2005, a Procuradoria Geral da República ajuizou a Ação Direta de Inconstitucionalidade (ADI) 3.526 a fim de impugnar diversos dispositivos da atual Lei de Biossegurança - Lei 11.105/05, abordando também a questão que toca ao estudo prévio de impacto ambiental. A decisão final ainda aguarda julgamento pelo Supremo Tribunal Federal. ${ }^{354}$

A questão da obrigatoriedade do estudo prévio de impacto ambiental, nos termos do art. 225 da $\mathrm{CF} / 88$, até hoje gera acirradas discussões. Os argumentos dos defensores ${ }^{355}$ da competência da CTNBio para deliberar sobre os transgênicos e dispensar o estudo do impacto ambiental, em situações justificáveis podem ser resumidos: tanto o estudo de impacto ambiental como a avaliação de risco da CTNBio possuem objetivos comuns, orientados pelo princípio da precaução, quais sejam, identificar implicações negativas do projeto, avaliar benefícios e custos ambientais e alimentar. Além disso, ambos exigem equipes multidisciplinares, em ambos os custos cabem ao proponente, ambos preveem monitoramento em fase posterior ao licenciamento (não realizado na prática no caso de EIA, por deficiência administrativa no país). Ademais, alegam que a CTNBio segue padrões internacionais de biossegurança para análise de risco, sendo mais completo e eficaz que o próprio estudo prévio de impacto ambiental. ${ }^{356}$

Quanto ao caráter vinculante das decisões da CTNBio, argumenta-se ser um órgão oficial do governo, dotado de imparcialidade e tecnicidade, agindo com prevalência do interesse público sobre o particular. Ademais, a própria CF/88 remeteu ao

354. Consulta disponível em <http://www.stf.jus.br/portal/processo/verProcessoAndamento.asp >. Acesso em: 16 de novembro de 2013. Em outubro de 2009, a Procuradoria Geral da República apresentou parecer pelo conhecimento e procedência da ação, e desde então, os autos do processo estão conclusos ao Ministro Relator.

355. É a posição, entre outros, de Nélson Nery Júnior. Rotulagem dos alimentos geneticamente modificados. Biotecnologia no Brasil: uma abordagem jurídica. São Paulo: ABIA, 2002, p.234.

356. Luciano Custódio Teixeira. Alimentos transgênicos: questões controversas. Revista de Direito do Consumidor. Vol. 77. Jan.-Mar./2011, p.312. 
legislador ordinário a competência para regular a imposição do estudo de impacto ambiental, o que ocorreu por meio da Lei de Biossegurança ao conferir as atribuições da CTNBio, que seria o órgão vinculado ao poder público (atendendo ao seu art. 225), ao qual a lei ordinária atribuiu a competência para deliberar em nome do Poder Público sobre a questão. Também a expressão "significativa degradação" contida no art. $225, \S 1^{\circ}$, inc. IV, da $\mathrm{CF} / 88$, é indicativa do tipo de risco que acarreta a exigência do estudo de impacto ambiental, e tal não ocorreria no caso de organismos geneticamente modificados. ${ }^{357}$

Exposta a questão, que bem ilustra a discussão acerca da omissão na adoção de medidas preventivas ou precautórias, cabe avaliar se caberia ao juiz intervir nessa decisão. Não é o propósito, e nem caberia realizar no espaço desta pesquisa, uma ampla análise acerca da natureza jurídica dos atos administrativos discricionários, tampouco as teorias que os fundamentam. A análise da questão estará centrada, sobretudo, no aspecto pragmático.

No tocante à aplicação dos princípios da precaução e da prevenção pela Administração Pública, é possível realizar o controle jurisdicional a partir de dois aspectos. O primeiro, no tocante à restrição excessiva dos princípios gerais da atividade econômica (art. 170, CF/88), como medidas que implicam proibição absoluta de comercialização, produção ou transporte de produtos. Neste caso, o magistrado deverá valer-se essencialmente do princípio da proporcionalidade, bem como dos outros instrumentos já abordados para o equacionamento da situação (análise custo-benefício, gravidade do possível dano, valores sociais etc.).

O segundo, e que toca mais diretamente à Responsabilidade Civil Preventiva, diz respeito a não adoção de medidas preventivas ou precautórias. Recorde-se, que em observância ao princípio da inafastabilidade do controle jurisdicional sobre os atos que regem a Administração Pública, segundo o qual a lei não excluirá da apreciação do Poder Judiciário lesão ou ameaça a direito, estabelecido na Constituição Federal em seu art. $5^{\circ}$, inciso XXXV, caberá intervir na decisão administrativa quando os atos normativos ou fiscalizatórias não estiverem condizentes com a lei ou princípios que estabelecem uma cautela preventiva, não apenas na fase da gestão dos riscos (risk management - aplicação ou não de medidas), mas também com relação à sua avaliação (risk assessment - 
necessidade ou não, diante da gravidade e extensão dos riscos). Essa compreensão não passou à margem da jurisprudência brasileira, especialmente quando se trata das Agências

Reguladoras, em ocasião em que a autonomia desta foi julgada relativa, cabendo ao Poder Judiciário garantir a aplicação do princípio da precaução quando aquela for omissa a seu respeito. Como exemplo, temos o caso decidido pelo TRF-2 ${ }^{\mathrm{a}}$ Região, em demanda movida pelo Ministério Público Federal em desfavor da ANATEL (Agência Nacional de Telecomunicações), com o escopo de impedir a instalação descontrolada de antenas de telefonia celular em municípios fluminenses. O trecho do voto enuncia que:

\begin{abstract}
Da análise dos autos e conforme recentes notícias veiculadas sobre o tema, conclui-se que, até a presente data, não se chegou a um consenso sobre os supostos malefícios que a radiação não-ionizante, proveniente das ERBS, causaria à saúde da população. Deste modo, a dúvida faz com que o Poder Público se veja na obrigatoriedade de levar em conta o princípio da precaução, norteador do Direito Ambiental. ${ }^{358}$
\end{abstract}

358. Brasil - TRF-2 - Sexta Turma Especializada - AC: 200351020063750 RJ 2003.51.02.006375-0, Relator: Desembargador Federal Guilherme Calmon Nogueira da Gama, Data de Julgamento: 26/07/2010, Data de Publicação: E-DJF2R - Data::23/08/2010 - Página::214/215. Ementa: “DIREITO ADMINISTRATIVO E AMBIENTAL. AÇÃO CIVIL PÚBLICA. FISCALIZAÇÃO POR PARTE DA ANATEL DAS ANTENAS DE TELEFONIA CELULAR - ERBs. SAÚDE DA POPULAÇÃO. PRINCÍPIO DA PRECAUÇÃO. 1. Trata-se de remessa necessária e apelações cíveis interpostas pela ANATEL e pelo Ministério Público Federal, contra sentença originária do Juízo da $2^{\text {a }}$ Vara Federal de Niterói. Versa a lide sobre pedido formulado pelo Ministério Público Federal, em ação civil pública, objetivando, em síntese, impedir a instalação descontrolada de antenas de telefonia celular, tecnicamente denominadas Estações Rádio-Base - ERBs, no âmbito dos municípios de Niterói e São Gonçalo. Tem como escopo a proteção à saúde da população, ao meio ambiente e ao patrimônio paisagístico. [...] 5. Da análise dos autos e conforme recentes notícias veiculadas sobre o tema, concluise que, até a presente data, não se chegou a um consenso sobre os supostos malefícios que a radiação não-ionizante, proveniente das ERBS, causaria à saúde da população. Deste modo, a dúvida faz com que o Poder Público se veja na obrigatoriedade de levar em conta o princípio da precaução, norteador do Direito Ambiental. 6. Em que pese a fundamentação expendida na sentença, não se afigura razoável, nem se vislumbra atingido o princípio da eficiência, obrigar-se à Agência Reguladora a operar três vistorias, uma antes da instalação da ERB, outra após a instalação e a última, anualmente. 7. No entanto, há que se manter a decisão quanto à obrigatoriedade de vistoria no local onde se situa a ERB, após sua instalação provisória, tal como se dá com os outros tipos de antena no âmbito das telecomunicações, e consoante normativos referentes ao serviço de telefonia móvel elencados na apelação da ANATEL. 8. De fato, vislumbra-se o cabimento e a correta concretização dos princípios da precaução e da eficiência, exigir que a ANATEL confirme, pessoalmente, através de seus agentes técnicos, as medições que se referem às emissões das ondas de radiofreqüência, atribuindo-se, em consequência, razão ao Parquet Federal [...]11. Impende ressaltar ainda que, desta forma, não estaria o Poder Judiciário adentrando na esfera de competência da ANATEL, mas tão somente adequando sua atuação aos ditames legais, abandonando uma postura omissa, diante do seu dever de fiscalização de padrões de segurança fixados pela própria Administração. Inexistiria, desta forma, a alegada violação à Lei ${ }^{\circ} 9.472 / 97$. 12. A dificuldade de disponibilização de recursos públicos para que a ANATEL possa realizar as diversas tarefas a que está obrigada não pode ser oposta para impedir o cumprimento do aqui se exige, tendo em vista que as determinações visam o cumprimento, por parte da apelante, de suas obrigações básicas de órgão fisscalizador, em prol da segurança e da saúde da população envolvida. 13. Remessa necessária e apelação da ANATEL parcialmente providas. Apelação do MPF julgada prejudicada. Mantida a concessão de liminar.” 
Referida decisão comprova que no ordenamento jurídico brasileiro, os princípios da precaução e da prevenção não se revestem do caráter de simples "diretiva", e incorporam um efetivo valor normativo à disposição do magistrado na orientação de suas decisões.

É inegável que a ciência, porquanto incerta, produz inovações tecnológicas extremamente poderosas e úteis para a sociedade. No entanto, o reconhecimento de contingências traz uma série de questionamentos sobre o que o progresso proporciona à vida das pessoas e à civilização.

Se as respostas não são conclusivas, a urgência quantitativa (mais tecnologia, mais riscos) e qualitativa (limitação de conhecimento para lidar com os riscos), ou ainda que conclusivas os seus efeitos devem ser evitados, torna os princípios da precaução e da prevenção excelentes instrumentos com os quais os ordenamentos jurídicos podem contar para a proteção do indivíduo e da sociedade, e para além disso, como componente do sistema de responsabilidade civil, ${ }^{359}$ dado o caráter normativo que lhes permite expandir os seus domínios na qualidade de princípios diretores, e permear a difusão de valores no direito positivo, em reforço à sua função essencial: evitar a ocorrência de danos graves decorrentes de riscos certos ou incertos. Sendo assim, são princípios que em razão do conteúdo que expressam, devem ser observado de forma primária, expressando uma hierarquia substancial e qualitativa no sistema jurídico.

Cumprida a análise dos princípios que estruturam o modelo da Responsabilidade Civil Preventiva, cumpre, a seguir, demonstrar que o instituto justificase, juridicamente, em deveres e bens os quais a ordem constitucional estabelece como fundamentais, caracterizando um novo paradigma para a responsabilidade civil: o paradigma da fundamentalidade.

359. É o que defende BOUTONNET, Mathilde. Le principe de précaution en droit de la responsabilité civile. Paris: L.G.D.J., 2005, p.33 et seq. 


\section{CAPÍTULO 2. DEVERES E BENS JUSTIFICADORES DA RESPONSABILIDADE CIVIL PREVENTIVA: O PARADIGMA DA FUNDAMENTALIDADE}

Inicialmente, cumpre ressaltar que a responsabilidade, enquanto dever ético na sociedade contemporânea, já foi trabalhada especificamente na Parte I desta pesquisa. Resta, agora, demonstrar que o compromisso de proteção também é imposto juridicamente, e não se confina unicamente ao campo das regras morais.

Parte dos autores que relacionam a responsabilidade civil aos princípios da precaução e da prevenção, normalmente estabelecem a sua justificação a partir da constatação de que danos graves e irreversíveis, decorrentes de riscos certos ou incertos, necessitam ser evitados. ${ }^{360}$ Referido enfoque, porquanto incorrigível, apresenta uma visão parcial do fenômeno da responsabilidade, posto que direciona o olhar unicamente para a evitabilidade das consequências.

O propósito deste capítulo é demonstrar outro norte justificativo para a Responsabilidade Civil Preventiva - abstraindo do paradigma das consequências, rumo ao paradigma da fundamentalidade. Com efeito, percebe-se que a verdadeira razão para a atuação do instituto com especial enfoque preventivo não reside nos possíveis efeitos, ainda que sobressalte a sua repercussão. O que efetivamente justifica a sua expansão são os deveres e bens dotados de fundamentalidade por força da Constituição Federal.

Uma breve digressão, para a perfeita compreensão do enfoque.

A norma jurídica compreendida como razão (ratio) se desdobra em acepções segmentadas quando observada a partir: da finalidade (anima legis); do fundamento (medulla legis); da decisão (ratio decidendi). Mas, dentre tantos caracteres de interesse, o que nela se manifesta tem ponto de encontro com o tema responsabilidade

360. Nesse sentido: TAPINOS, Daphné. Prévention, précaution et responsabilité civile : risque avéré, risque suspecté et transformation du paradigme de la responsabilité civile. Paris: L'Harmattan, 2008, p.21; BOUTONNET, Mathilde. Le principe de précaution en droit de la responsabilité civile. Paris: L.G.D.J., 2005, p.190; THIBIERGE, Catherine. Libres propôs sur l'évolution du droit de la responsabilité: vers um élargissement de la fonction de la responsabilité civile? Revue Trimestrielle de Droit Civil. Paris. n.3. p.561-84. juil./sept. 1999. 
civil: a norma jurídica é sentido de imputação. ${ }^{361}$ Em outras palavras: há determinada suposição de fato e a consequência jurídica (fattispecie e estatuição normativa), ${ }^{362}$ mas o vínculo entre ambas é justamente a imputação. ${ }^{363}$

A seu turno, os deveres - antes de previstos como modelo constitucional ao lado dos direitos fundamentais - representam um meio de expressão da norma no cariz estático, especialmente no direito privado, porém, em outra espécie mais concentrada: o dever jurídico. Localiza-se, nesta vertente, adstrito à estrutura interna da relação jurídica ao lado do direito subjetivo, já que na estrutura externa estariam outros elementos (sujeitos, objeto, fato jurídico e garantia). Neste entendimento:

No dever jurídico - contraposto aos direitos subjectivos propriamente ditos - o sujeito do dever, expondo-se embora a sanções, tem a possibilidade prática de não cumprir. O direito ordena ao titular do dever jurídico que observe um determinando comportamento e apoia esta ordem ou comando com as sanções jurídicas dirigidas ao obrigado que, dolosa ou negligentemente, se exime ao cumprimento do dever. ${ }^{364}$

Assim, sob essa ótica, o dever é meramente reflexivo ao direito subjetivo, o que limita a existência desta modalidade jurídica a outra, a ponto de aparentar certa condição ontológica. Portanto, adotando essa perspectiva, o dever não poderia ser revelado como categoria jurídica autônoma.

Em posição diversa, Hans Kelsen, ${ }^{365}$ ao discordar sobre a pertinência do direito subjetivo ante a afirmação do direito objetivo, explicita que nem sempre o dever jurídico é dependente e anverso do direito subjetivo. Como exemplo, menciona o serviço militar, porque a conduta a ser satisfeita (dever) não se refere a outro indivíduo "situado" ou determinado, senão à comunidade.

361. VASCONCELOS, Arnaldo. Teoria da norma jurídica. 6 ed. São Paulo: Malheiros, 2006. Indica como sucede o pensamento normativista ortodoxo de Kelsen: "A maneira exclusiva, portanto, de uma conduta penetrar no mundo do Direito é ser-lhe imputada uma sanção, donde o destaque ímpar ao ilícito. E nisso consistiu o giro doutrinário do fundador da Teoria Pura do Direito. Como le, e depois dele, o ilícito vai ocupar posição intra-sistemática no Direito".

362. NORONHA, Fernando. Direitos das obrigações. Vol. 1. $2^{\mathrm{a}}$ ed. São Paulo: Saraiva, 2007, p.345.

363. FALCÓN y TELLA, Maria José. Lições de teoria geral do direito. Trad. Cláudia de Miranda Avena, Ernani de Paula Contipelli. São Paulo: Revista dos Tribunais, 2011, p.53.

364. MOTA PINTO, Carlos Alberto. Teoria geral do direito civil. $4^{\mathrm{a}}$ ed. Coimbra: Coimbra Editora, 2005, p.185.

365. KELSEN, Hans. Teoria pura do direito. Trad. João Batista Machado. $4^{\text {a }}$ ed. São Paulo: Martins Fontes, 1994, p.143. 
Para melhor entendimento, é importante estabelecer, mesmo que singelamente, as distinções entre direito subjetivo, dever e obrigação. O direito subjetivo expressa o poder reconhecido pelo ordenamento ao seu titular para realizar interesse próprio. Em concepção mais atual e evoluída, abandona-se a carga egoística de mera vontade, para abranger a noção de exercício limitado no sistema, porque atua em um "âmbito de liberdade concreta reconhecido ao sujeito, mas com limites"366 (a exemplo do abuso do direito alçado à categoria de ato ilícito no Código Civil). Já a obrigação tem por característica essencial ser correlata ao direito de crédito, ao passo que o dever representa uma "situação passiva de conteúdo genérico, que não se especifica em algum comportamento determinado". 367

Portanto, segue observação relevante para o propósito desta pesquisa: enquanto o direito subjetivo referindo-se a carga de autonomia ou faculdade da pessoa pode, por isso, ser renunciado, o dever é marcado pela necessidade, não sendo deferido a ninguém liberar-se do cumprimento senão conforme a lei. ${ }^{368}$ Ademais, as figuras também podem estar jungidas em uma mesma norma, como no caso dos poderes-deveres que exprimem determinada finalidade que transcende o titular, sendo compreendidos como direitos funcionais $^{369}$ (por exemplo, poder familiar em que o pai deve projetar a favor dos filhos).

Quanto à teoria geral do Direito civil, igualmente, a mesma não vinculou, por si só, o dever jurídico ao direito subjetivo. É importante verificar que as normas, a dogmática e a hermenêutica do direito privado trouxeram ao dever jurídico posição de

366. MENEZES CORDEIRO, António. Tratado de direito civil português. Parte geral. Tomo I. Coimbra: Almedina, 2007, p.332.

367. PERLINGIERI, Pietro; FEMIA, Pasquale. Nozioni introduttive e principi fondamentali del diritto civile. $2^{\mathrm{a}}$ ed. Napoli: Edizione Scientifiche italiane, 2004, p.121. Em língua original: "situazione passiva a contenuto generico che non si specifica in alcum comportamento determinato". Os mesmos autores apresentam para o direito italiano a diferenciação de tratamento ainda no âmbito da obrigação, entre obbligazione e obbligo, já ambas designado obrigações têm escopos diversos: "Le situazione soggettive passive correlate al diritto soggettivo sono l'obbligazione e l'obbligo. L'obbligazione è la situazione correlata al diritto di credito: è catterizzata dal dovere di eseguire una determinata prestazione patrimoniale per la soddisfazione di un interesse anche patrimoniale del creditore (1174). L'obbligo è la situazione correlata caratterizzata dalla non patrimonialità della prestazione: in tale ipotesi anche il diritto soggettivo è non patrimoniale (ad es. l'obbligo di fedeltà.) [...] altrettanto spesso in luogo di 'obbligo' si impiega dovere”.

368. COVIELLO, Nicolas. Doctrina general del derecho civil. $4^{\mathrm{a}}$ ed. Buenos Aires: Librería El Foro, 2003, p. 25.

369. CAPELO DE SOUZA, Rabindranath. Teoria geral do direito civil. Tomo I. Coimbra: Coimbra Editora, 2003, p.185. 
destaque e independência, abaixo demonstrada.

Em primeiro passo, observa-se que o Código Civil de 2002 inicia o art. $1^{\mathrm{o}}$ de forma distinta da codificação anterior. Enquanto na legislação passada, pelo art. $2^{\circ}$, fixava-se somente ao homem capacidade de direitos e obrigações na órbita civil, o atual estatuto legislativo consagra a toda pessoa capacidade de direitos e deveres na seara privada. A diferença é significativa: o Código Civil de 1916, acompanhando a ideologia liberal e patrimonialista de então e filiando-se à modalidade obrigação encerrava as potencialidades humanas passivas no binômio crédito-débito (sujeito ativo, sujeito passivo e prestação).

Em posição diversa, a legislação civil atual, ao vincular o conceito de pessoa à capacidade de direitos e deveres, permite na última figura transcender o caráter meramente patrimonial, ampliando a garantia de promoção da pessoa nas situações subjetivas existenciais e extrapatrimoniais. ${ }^{370}$ Aliás, o Código Civil prevê em diversos outros dispositivos a estatuição de deveres, com destaque: proteção aos direitos da personalidade (arts. 11 e 12); fidelidade entre cônjuges (art.1566, I); sustento aos filhos (art.1566, IV); zelo por parte do tutor (art.1741); alimentos (art.1.694); diligência e cuidado do administrador da sociedade (art.1011), e outros.

Recorde-se, ainda, que há deveres identificados além da regra positivada. Isto porque, na esfera das relações obrigacionais ganhou relevante expressão dogmática o princípio da boa-fé, compreendido como a reforma ética do direito privado. ${ }^{371}$

A partir do reconhecimento da complexidade do processo obrigacional, ${ }^{372}$ a boa-fé firmou-se como cláusula permanente de dever de lealdade e cooperação entre as partes, avançando com escopos diversos e em etapas diferenciadas nas relações negociais, como: a) nas tratativas pré-contratuais; b) na interpretação do contrato; c) na execução do contrato; d) na pendência de condição; e) no inadimplemento do contrato e eventual

370. MEIRELLES, Jussara Maria Leal de. Economia, patrimônio e dignidade do pródigo: mais um distanciamento entre o ser e o ter? In: Gustavo Tepedino e Luiz Edson Fachin (coord.).O direito e o tempo: embates jurídicos e utopias contemporâneas. Estudos em homenagem ao Professor Ricardo Pereira Lira. Rio de Janeiro: Renovar, 2008, p.179.

371. LOTUFO, Renan. 20 anos do Código de Defesa do Consumidor: conquistas, desafios e perspectivas. São Paulo: Saraiva, 2011, p.8.

372. SILVA, Clóvis Veríssimo do Couto e. A obrigação como processo. Rio de Janeiro: Editora FGV, 2007, p.63. 
exceção; f) na vedação de exercício inadmissível de posição jurídica.

Entretanto, a mencionada compreensão da complexidade obrigacional revelou categorias mais específicas, com funções igualmente definidas e distintas, que influenciam cada qual no plano da eficácia negocial e no programa contratual. ${ }^{373} \mathrm{~A}$ hermenêutica, por consequência, permite perceber nas relações obrigacionais: deveres principais, deveres secundários e deveres de fidúcia (ou anexos), consoante se depreendem:

A boa-fé na execução dos contratos adveio da própria ideia de complexidade intraobrigacional, desenvolvida, a partir de certa altura, por Siber e, mais tarde, da sua junção com a teoria da violação positiva do contrato, descoberta por Hermann Staub, que também seria aproximada a boa-fé. Em síntese: não basta a execução matemática da prestação: devem ser respeitados deveres (acessórios) de lealdade, de informação e de segurança, para que o fim da obrigação seja mesmo alcançado, para que os valores fundamentais do ordenamento seja observados e para que não ocorra danos colaterais inúteis. ${ }^{374}$

Corresponde a esse cenário a reforma ocorrida no Bürgerliches Gesetzbuch (BGB) que introduziu no corpo da codificação alemã o item 2 no §241, mediante a seguinte redação: “(2) A relação obrigacional também pode, segundo o seu conteúdo, obrigar cada parte ao respeito pelos direitos, pelos bens jurídicos e pelos interesses da outra parte". 375

Assim, se por força da relação obrigacional o credor tem direito a exigir do devedor uma prestação, mesmo que seja omissiva - o que, aliás, representa o item 1 do $\S 241$ do $\mathrm{BGB}^{376}$ - a introdução da nova redação acima referida permite compreender que o legislador germânico ocupou-se, no caso, com o dever cuidado ou respeito da parte com os

373. MARTINS-COSTA, Judith. Contratos. Conceito e evolução. In: LOTUFO, Renan; NANNI, Giovanni Ettore (Coord.). Teoria geral dos contratos. São Paulo: Atlas, 2011, p.56. A autora apresenta abordagem interessante quanto à eficácia no que respeita à dupla valência da vinculação contratual como ato de determinação (fixação de direitos, deveres e obrigações) como ato de comunicação (geradora de legítima expectativa socialmente averiguáveis).

374. MENEZES CORDEIRO, António. Tratado de direito civil português. vol. II. Direito das obrigações. t. 1. Coimbra: Almedina, 2009, p.300.

375. PATTI, Salvatore. Codice civile tedesco. Milano: Giuffrè, 2005, p.123. Tradução livre. No original: "(2) Il rapporto obbligatorio può obbligare, secondo il suo contenuto, ciascuna parte al rispetto dei diritti, dei beni giuridici e degli interessi dell'altra parte".

376. PATTI, Salvatore. Codice civile tedesco. Milano: Giuffrè, 2005, p.123. No original: “(1) In forza del rapporto obbligatorio il creditore è legittimato ad esigere uma prestazione dal debitore. La prestazione può anche consistere in una omissione". 
interesses do alter. Portanto, aos adeptos da crítica de que não há responsabilidade civil sem danos, ${ }^{377}$ já se observa exegese análoga: obrigação sem o dever de prestar. ${ }^{378}$

São deveres, via de consequência, que advêm do exercício expansivo e elucidativo da cláusula geral de boa-fé conectando o sistema jurídico ao sistema social a partir da confiança gerada e legitimamente esperada, sincrônica ou diacronicamente. ${ }^{379}$ Neste passo, a contribuição doutrinária esclarece que:

Os deveres fiduciários, anexos, laterais, ou simplesmente meros deveres de conduta (às vezes chamados também de deveres correlatos, ou colaterais), são aqueles que somente apontam procedimentos que é legítimo esperar por parte de quem, no âmbito de um específico relacionamento obrigacional (em especial quando seja contratual ou ainda précontratual ou pós-contratual, e até supracontratual, isto é, neste caso, sendo concomitante a um contrato, mas indo além dele), age de acordo com os padrões socialmente recomendados de correção, lisura e lealdade, que caracterizam o chamado princípio da boafé contratual. ${ }^{380}$

Referida "obrigação sem dever primário de prestação" foi elaborada pela doutrina alemã com inspiração nos $\S \S 823$ e seguintes do BGB, e acabou absorvida pela doutrina italiana através da "teoria da responsabilidade por contato social". Esta, segundo Mario Barcellona, ${ }^{381}$ é uma regra criada por via analógica, segundo a qual qualquer situação de contato social que produza confiança submete os sujeitos desse contato ao dever (sem prestação), de proteger a esfera jurídica de quem foi gerada a respectiva confiança.

Para o jurista italiano, Carlo Castronovo, também em comentários à referida teoria, a "relação obrigatória sem dever de prestação" está confinada às tratativas

377. Nesse sentido: ANGELIN, Karinne Ansiliero. Dano injusto como pressuposto do dever de indenizar. Dissertação de Mestrado. Faculdade de Direito da Universidade de São Paulo. São Paulo. 2013. p. 132 .

378. MENEZES CORDEIRO, António. Tratado de direito civil português. vol. II. Direito das obrigações. t. 1. Coimbra: Almedina, 2009, p.301.

379. LORENZETTI, Ricardo Luis. Teoria da decisão judicial: fundamentos de direito. Trad. Bruno Miragem. São Paulo: Revista dos Tribunais, 2010, p.172.

380. NORONHA, Fernando. Direito das obrigações. Vol. 1. 2a ed. São Paulo: Saraiva, 2007, p. 80.

381. Trattato della responsabilità civile. Torino: Utet Giuridica, 2011, p. 72. 
precontratuais. $^{382}$

Contudo, como bem recorda Antônio Junqueira de Azevedo, ${ }^{383}$ a obrigação de segurança, na atualidade, está descontratualizada, "de tal forma que, até mesmo sem contrato, qualquer pessoa que tenha algum poder físico sobre outra é responsável por sua segurança". Esta consideração, aliás, é a base para que o notável professor construísse a tipologia “dano social”, que já encontra ressonância jurisprudencial, ${ }^{384}$ ao considerar que além da lesão ao patrimônio material ou moral da vítima, é possível que o dano atinja toda a sociedade, em um rebaixamento do nível de vida da população, o que é evidente quando se trata de segurança (intranquilidade social) ou quebra da confiança (redução da qualidade coletiva de vida).

Com esta concepção que visualiza a obrigação (aqui melhor compreendida como dever) de segurança autônoma, a responsabilidade funda-se, sobretudo, na tutela da confiança em função das expectativas geradas, sobretudo em consideração ao dever de informação que decorre da risk communication, já referida anteriormente, com relação aos riscos que determinada atividade ou produto podem ocasionar. Este perfil de responsabilidade põe em causa a clássica summa diviso entre responsabilidade contratual e extracontratual, e incorpora, nos dizeres de Carneiro da Frada, "uma dimensão prudencial

382. La nuova responsabilità civile. Milano: Dott. A. Giuffrè Editore, 2006, p. 457. Em língua original: "In primo luogo essi invece, nel constituire un preciso dovere di comportamento volto a tutelare una specifica sfera giuridica altrui, segnano la diversità dalla responsabilità aquiliana. Quest'ultima infatti è caratterizzata $\mathrm{ab}$ origine dalla'assenza di doveri di comportamento rivolti a favore di persone determinate: colui che non è vincolato da obblighi è totalmente libero fino a quando non si verifichi la lesione del diritto altrui, salvo che non ricorrano gli estremi di un'azione inibitoria; tale lesione, a prescindere da quasiasi dovere, in realtà inesistente, genera la responsabilità, la quale per definizione non si situa in esito a un vinculum iuris, ma ne rappresenta il sorgere. La responsabilità da violazione di un obbligo di protezione, al contrario, pressuppone appunto un obbligo e perciò si configura come infrazione di un rapporto che lega già i soggetti, attivo e passivo, della fattispecie di danno".

383. Por uma nova categoria de dano na responsabilidade civil: o dano social. Novos estudos e pareceres de direito privado. São Paulo: Saraiva, 2009, p. 380-381.

384. Brasil - TJSP - 4 ${ }^{\text {a }}$ Câmara de Direito Privado - Ap. Cível 0027158-41.2010.8.26.0564 - Rel. Teixeira Leite - Data do julgamento: 18/07/2013. Ementa: "PLANO DE SAÚDE. Pedido de cobertura para internação. Sentença que julgou procedente pedido feito pelo segurado, determinado que, por se tratar de situação de emergência, fosse dada a devida cobertura, ainda que dentro do prazo de carência, mantida. DANO MORAL. Caracterização em razão da peculiaridade de se cuidar de paciente acometido por infarto, com a recusa de atendimento e, consequentemente, procura de outro hospital em situação nitidamente aflitiva. DANO SOCIAL. Caracterização. Necessidade de se coibir prática de reiteradas recusas a cumprimento de contratos de seguro saúde, a propósito de hipóteses reiteradamente analisadas e decididas. Indenização com caráter expressamente punitivo, no valor de um milhão de reais que não se confunde com a destinada ao segurado, revertida ao Hospital das Clinicas de São Paulo. LITIGÃNCIA DE MÁ FÉ. Configuração pelo caráter protelatório do recurso. Aplicação de multa. Recurso da seguradora desprovido e do segurado provido em parte." 
que caracteriza especificamente a interação dos sujeitos; transcendendo com isso o paradigma da causalidade envolvido nas demais formas de responsabilidade". ${ }^{385}$

No Brasil, a responsabilidade pelo contato social, como fundamento para a prevenção de danos, é defendida por Annelise Monteiro Steigleder, ${ }^{386}$ bem como José Rubens Morato Leite e Patryck de Araújo Ayala, ${ }^{387}$ não se fazendo necessária a concretização do dano, pois as externalidades ambientais negativas já seriam suficientes para gerar responsabilidade pelo perigo, ou risco, a que a sociedade é exposta.

Conclui-se, logicamente, que o direito privado avançou na hermenêutica, no sentido de ex ante obrigar, ex ante punir, ex ante admitir a lesão à vítima, e ex ante indicar os valores fundamentais que sustentam o sistema através dos deveres.

Assim, na gama de transformações que a Sociedade de Riscos promoveu à realidade social, destaca-se a necessidade de uma apreensão global do fenômeno que possivelmente poderá tocar a responsabilidade civil, em detrimento de uma perspectiva meramente consequencialista (ex post). Sob esse viés, os elementos que precedem um possível resultado danoso (risco) tornam-se juridicamente relevantes, a partir da admissão da incidência dos princípios da precaução e da prevenção nesse âmbito temporal que precede o resultado naturalístico.

Neste ponto, retorna-se ao raciocínio difundido pela teoria da "obrigação como um todo e como processo", de Karl Larenz, ${ }^{388}$ e difundida no Brasil por Clóvis Couto e Silva, que destaca o aspecto dinâmico que percorre o vínculo obrigacional, ao estabelecer que "a obrigação, vista como processo, compõe-se, em sentido largo, do

385. FRADA, Manuel António de Castro Portugal Carneiro da. Teoria da confiança e responsabilidade civil. Coimbra: Almedina, 2004, p. 903.

386. STEIGLEDER, Annelise Monteiro. Responsabilidade civil ambiental: as dimensões do dano ambiental no direito brasileiro. $2^{\mathrm{a}}$ ed. Porto Alegre: Livraria do Advogado, 2011, p. 157.

387. LEITE, José Rubens Morato; AYALA, Patryck de Araújo. Dano ambiental: do individual ao coletivo extrapatrimonial. $4^{\text {a }}$ ed. São Paulo: RT, 2011, p. 139.

388. Derecho de obligaciones. Trad. Jaime Santos Briz. Madrid: Revista de Derecho Privado, 1958, p. 219. Nas palavras do jurista alemão: “Bajo este concepto entendemos la 'relación de obligación' no sólo como lo hace la ley [...], es decir, como la relación de prestación aislada (crédito y deber de prestación), sino como la relación jurídica total [...] fundamentada por un hecho determinado [...] y que se configura como una relación jurídica especial entre las partes. [...] por el hecho mismo de que en toda relación de obligación late el fin de la satisfacción del interés en la prestación del acreedor, puede y debe considerarse la relación de obligación como un processo. Está desde un principio encaminada a alcanzar un fin determinado y a extinguirse con la obtención de ese fin”. 
conjunto de atividades necessárias à satisfação de interesses do credor”. 389

Adaptando-se o referido enunciado à responsabilidade civil extracontratual, é possível afirmar que por força da incidência dos princípios da precaução e da prevenção, "a responsabilidade, vista como processo, compõe-se, em sentido largo, do conjunto de atividades necessárias à satisfação do neminen laedere, qual seja, a não ocorrência de danos." Se na visão do mencionado jurista, "é precisamente a finalidade que determina a concepção da obrigação como processo", 390 pode-se igualmente compreender que é precisamente a prevenção de danos (função preventiva prospectiva) que determina a concepção da responsabilidade como um processo dinâmico, com atuação ex ante e ex post.

Assim, complementar à noção de responsabilidade civil como um processo, é possível afirmar que os princípios da precaução e da prevenção originam deveres de proteção, que terão uma relevante atuação na determinação da Responsabilidade Civil Preventiva, posto que incidem no período anterior à efetivação de um dano, precisamente no momento concernente à avaliação, gestão e informação de riscos. Ocorre que na fase anterior ao dano, aqui compreendido no seu sentido clássico de pressuposto da responsabilização, os sujeitos encontram-se no exercício de suas esferas de liberdade. E é justamente no exercício desta que deverão se manifestar os deveres para a prevenção em sentido lato. Desse modo, é possível que o instituto promova o valor social da segurança.

Recorde-se, em analogia, que para a configuração da responsabilidade civil pré-contratual, originária da clássica figura da culpa in contrahendo de Rudolph Von Ihering, ${ }^{391}$ porém, abstraindo-se da culpa para uma dimensão objetiva, desnecessário se faz a ocorrência de inadimplemento negocial (o dano ou prejuízo contratual), pois a mesma

389. A obrigação como processo. Rio de Janeiro: Editora FGV, 2006, p.20.

390. SILVA, Clóvis Couto. Op.cit., p.21.

391. Culpa in contrahendo. Ou indemnização em contratos nulos ou não chegados à perfeição Trad. Paulo Cardoso C. Mota Pinto. Coimbra: Almedina, 2008: "Quem contrata, sai deste modo do círculo de deveres puramente negativo do tráfico extracontratual e entra no positivo da esfera contratual, sai do campo da mera culpa in faciendo para o da culpa in non faciendo, da diligentia positiva, e a primeira e mais geral obrigação que assim assume é a seguinte: aplicar a necessária diligentia logo no próprio contratar. Não são apenas as relações contratuais formadas, mas antes logo as que estão em formação que têm de estar sob a protecção das regras sobre a culpa, se não se quiser que o tráfico contratual seja neste aspecto obstaculizado de forma significativa, que cada contraente seja exposto ao perigo de se tornar vítima da negligência alheia". 
deriva da violação de deveres na fase anterior à efetiva celebração contratual, em nítida semelhança à imposição de deveres de proteção impostos pela função preventiva prospectiva da responsabilidade civil, o que comprova que o ordenamento atribui, de fato, significado jurídico a todos os momentos temporais em que recai sobre o sujeito a observância de um dever, no intuito de prevenir a ocorrência de um resultado de repercussões graves.

Portanto, precisamente no âmbito do direito privado, o dever jurídico compreende-se como fundamento de justificação, assimilação e aplicação da Responsabilidade Civil Preventiva, ensejando a visualização do dever de prevenção e dever de precaução (relacionados à segurança e proteção), que vinculam o Estado à sua observação, mas sobretudo, "indica que também os particulares estão juridicamente vinculados ao dever de proteção", 392 afirmando a sua respectiva responsabilidade.

O dever de prevenção, conforme visto no capítulo anterior, é entendido como aquela situação jurídica passiva atribuída a determinada pessoa frente a risco certo que deve ser evitado. Referido dever é tratado na codificação civil, apesar dos microssistemas que o preveem na atualidade adotarem metodologia legislativa diversa, como é o caso do Código de Defesa do Consumidor. ${ }^{393}$

Para melhor contextualização, veja-se dois exemplos.

392. Referido entendimento é exposto por SARLET, Ingo Wolfgand; FENSTERSEIFER, Tiago. Deveres fundamentais ambientais: a natureza de direito-dever da norma jusfundamental ambiental. Revista de Direito Ambiental. Ano 17. Vol. 67. p. 11-70. Jul.set. / 2012, p. 13: “A partir da análise do tratamento jurídico-constitucional dispensado à proteção do ambiente pela Constituição Federal de 1988, constatase que a norma constitucional, além de enuncar deveres de proteção estatais em matéria ambiental, igualmente afirmou a responsabilidade dos particulares [...] Assim, importa consignar que nesta perspectiva são atribuídos aos particulares tanto direitos como deveres fundamentais em matéria ambiental, deveres que, por sua vez, não se confundem com os deveres de proteção e promoção ambiental do Estado [...]”.

393. Cláudia Lima MARQUES esclarece: “O CDC, como codificação, é parcial, é uma pequena (micro) codificação especial, privilegiadora de um sujeito ou grupo de sujeitos. O CDC é um conjunto de normas sistematicamente organizado, destacando-se os três capítulos iniciais como os mais importantes do seu "sistema" (= ordem, todo construído, corpo, limite), a definir seu campo ou âmbito de aplicação (ao que se aplica esta lei), os objetivos (para que se aplica a lei), os princípios básicos da lei (como se aplica valoradamente esta lei) e os direitos básicos do consumidor (assegura o nível de eficácia de aplicação desta lei). [...] O sui generis do CDC aqui não é seu sistema, mas a completude e a ordem de seu sistema [...]. In: BENJAMIN, Antônio Herman V.; MARQUES, Cláudia Lima; BESSA, Leonardo Roscoe. Manual de Direito do Consumidor. São Paulo: Editora Revista dos Tribunais, 2007, p 44 e p. 52 . 
Inicialmente, a regra contida no art. 747 do Código Civil, que estabelece ao transportador o dever de recusar a coisa cujo transporte ou comercialização não sejam permitidos. Percebe-se claramente que o ordenamento atribui um non facere ao transportador no sentido de evitar transporte não permitido em razão de coisa inadequada ou proibida de ser comercializada. Sobre o ponto, Cláudio Luiz Bueno de Godoy relaciona a restrição legal "ao transporte de coisas perigosas, como combustíveis, por exemplo, que devem ensejar obrigatória recusa do transportador a tanto não adequado". 394

Ou seja, diante da suposição de que determinada atividade empresarial, sem adequações técnicas e regulatórias para transporte de produtos químicos passíveis de danos ecológicos, danos à saúde pública e até danos à vida (inclusive do próprio motorista), cujos tanques de embarque estão fixados próximos à pequena comunidade ribeirinha de pescadores, os órgãos protetivos devem valer-se da Responsabilidade Civil Preventiva para obstar o mencionado exercício, mesmo que não iniciado, por nítida quebra do dever de prevenção pelo empresário, sem prejuízo das medidas individuais homogêneas quanto aos danos patrimoniais e extrapatrimoniais advindos a cada morador, quer pelas despesas que desembolsaram para diminuir o impacto do dano em suas esferas quando eventualmente ocorresse, quer pela turbação da paz e sossego causados pelo temor de contaminação do seu meio de sustento.

Outro exemplo é cabível, no tocante ao art. 1291 do Código Civil, quando impõe ao possuidor o dever de não poluir as águas indispensáveis às necessidades vitais dos moradores dos imóveis inferiores, e de recuperar as demais águas poluídas por sua atuação. Inicialmente, quanto a este dispositivo, cumpre interpretação conjugada com a Constituição Federal, porque pelo disposto em seu art. 225, todos têm direito ao meio ambiente equilibrado, não se aceitando a poluição das águas indispensáveis e nem mesmo daquelas não essenciais. Este, inclusive, é o teor do Enunciado $244^{395}$ da III Jornada de Direito Civil do Conselho da Justiça Federal: “O art. 1291 deve ser interpretado conforme a Constituição, não sendo facultada a poluição de águas quer sejam essenciais ou não às

394. GODOY, Cláudio Luiz Bueno de. Código civil comentado: doutrina e jurisprudência: Lei 10.406/02. Cézar Peluso (Coord.). São Paulo: Manole, 2008, p.704.

395. Jornadas de direito civil: enunciados aprovados. Coordenador científico Ministro Ruy Rosado de Aguiar Júnior. Brasília: Conselho da Justiça Federal, Centro de Estudos Judiciários, 2012. Disponível em: http:/www.cjf.jus.br/cjf/CEJ-Coedi/jornadas-cej/enunciados-aprovados-da-i-iii-iv-e-v-jornada-dedireito-civil/compilacaoenunciadosaprovados1-3-4jornadadircivilnum.pdf. Acesso: 01 de agosto de 2013. 
primeiras necessidades de vida".

Portanto, é evidente o dever de prevenção que o possuidor deve ter diretamente em face dos vizinhos e indiretamente ao meio ambiente. No que respeita aos possuidores dos imóveis inferiores, a prevenção se destina à preservação da vida, quanto ao meio ambiente, a higidez. A hipótese é comum nas regiões rurais do país, especialmente quando determinado produtor está prestes a poluir as águas do rio em detrimento aos lindeiros, os quais para evitar a contaminação do gado previamente constroem poços artesianos de abastecimento. A pureza da água é fator de vida e valorização das propriedades rurais. A Responsabilidade Civil Preventiva evitaria a poluição, bem como possibilitaria o acesso à indenização de danos com despesas de prevenção pelos vizinhos. ${ }^{396}$ Neste ponto, cumpre observar que a jurisprudência francesa, ao tratar da indenização do risco (em si mesmo considerado), com aplicação dos princípios da precaução e da prevenção, associado ao trouble anormal de voisinage, já admite com tranquilidade este entendimento, consoante será tratado em momento próprio, na Parte II desta pesquisa.

Por sua vez, o direito privado também trabalha com hipóteses de dever de precaução, que consiste, como já tratado, na incerteza científica quanto à ocorrência de riscos, com suposição plausível de ocorrência de danos ao meio ambiente, à saúde e segurança. ${ }^{397}$ Assim, na conjunção do art. $4^{\text {o }}$, inciso V, do CDC, que versa sobre o incentivo à criação pelos fornecedores de meios eficientes de controle de qualidade e segurança de produtos e serviços, com os dispositivos contidos em seus artigos $8^{\circ}$ e 10 , que vedam a inserção no mercado de produtos especialmente perigosos - ou seja, aqueles que a nocividade ou periculosidade não é inerente, mas sim decorre de algum defeito de

396. Brasil. Tribunal de Justiça de São Paulo. JTACSP, 82/87. "Poluição de águas. Incômodo que foge a limite da tolerabilidade. Com a poluição das águas, o gado dos autores ficou impossibilitado de beber no rio, obrigando os autores a tomar outras providências, tais como a construção de poço ou a utilização de minas. É óbvio que a presença da água em qualquer propriedade rural é relevante fator de valorização, mas ocorre grande desvalorização quando essa água se torna poluída e de mau cheiro, imprópria para consumo dos homens e animais. O CC/1916, art. 554 [C, art. 1.277), assegura aos autores, como vizinhos, o exercício de ação, sem prejuízo das providências administrativas do órgão oficial, que, não obstante haver multado a ré, ainda não conseguiu receber a multa face à discussão provocada pela apelante".

397. LOPEZ. Teresa Ancona. Responsabilidade civil na sociedade de risco. In: Teresa Ancona Lopez, Patrícia Faga Iglecias Lemos e Otávio Luiz Rodrigues Junior (Coord.). Sociedade de risco e direito privado. São Paulo: Atlas, 2013, p.4. 


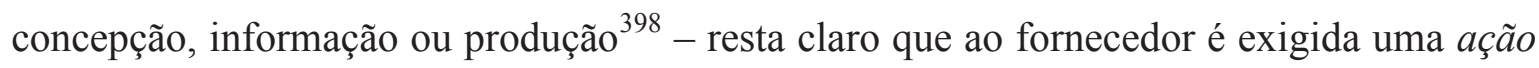
antecipada no sentido de evitar danos, considerando a incerteza científica do produto que colocou em circulação, até porque a norma parte do pressuposto de que ele "deveria saber" o alto grau de periculosidade.

Tal compreensão é respaldada, quando se busca na aplicação da lei atender aos fins sociais a que se destina (art. $5^{\circ}$, LINDB), pois a regra deve ser concretizada atendendo a realidade da vida contemporânea. O preceito normativo, mesmo possuindo escopo limitado e objetivo (informado pelo texto linguístico e pelas necessidades à época de sua elaboração) tem finalidade variável e móvel permitindo ao aplicador múltiplas decisões frente às situações fáticas diferentes e diacrônicas. ${ }^{399}$ Em idêntico sentido, especialmente considerando a pós-modernidade:

O tempo pós-moderno tem consagrado o fim do ideal universal descartiano, na base a qual para cada coisa existiria uma só verdade. Na época da complexidade social e do valor fundante e legitimador da diversidade, do pensamento múltiplo e do pluralismo (mesmo como pluralidade de diferentes espaços e temporalidade heterogênea), devem ser um preceito histórico-realístico para levar decisivamente à superação, exatamente contrário e oposto aquele epistemológico monístico do fundador da modernidade, para avisar e alertar que para cada coisa não existe uma só verdade, mas existem ou podem existir muitas verdades. $^{400}$

Portanto, a leitura atual dos dispositivos acima mencionados permite afirmar o dever de precaução do fornecedor aliado ao direito de informação do consumidor na seara privatista:

A precaução aplica-se no direito do consumidor através da efetivação do direito à informação, em nosso sentir, tendo em vista o que prescreve o art. 9. ${ }^{\circ}$ do CDC. Em se

398. BENJAMIN, Antônio Hermann V.; MARQUES, Cláudia Lima; BESSA, Leonardo Boscoe. Manual de direito do consumidor. São Paulo: Editora Revista dos Tribunais, 2007, p.43.

399. BONNECASE, Julien. The Problem of Legal Interpretation in France. Journal of Comparative Legislation and International Law. Third Series, vol. XII, 1930, p.90.

400. SCALISI, Vincenzo. Fonti-teoria-metodo: alla ricerca della regola giuridica nell'epoca della postmodernità. Milano: Giuffrè, 2012, p.97. Em língua original: "Il tempo postmoderno ha sancito la fine dell'ideale universalistico descartiano, in base al qual per ogni cosa esisterebbe una sola verità. Nell'epoca della complessità sociale e del valore fondativo e legitimante della diversità, del pensiero del molteplice e del pluralismo (intenso come pluralità di differenti spazi e temporalità eterogenere), dev'essere un precetto storico-realistico a prendere decisamente il sopravvento, exatamente contrario e oposto a quello epistemológico monístico del fondatore della modernità, per avvertirci e ammonirci che per ogni cosa non esiste una sola verità, ma esistono o possono esistere piú verità”. 
tratando de nocividade ou periculosidade potencial, mesmo que não provada, há um dever de informar qualificado, ampliado. Reconhece-se que há situações especiais cuja presença de um risco plausível, porém ainda não devidamente estabelecido pela ciência, acarreta $a$ obrigação de agir precauciosa. ${ }^{401}$

De todo o exposto, assevera-se que no âmbito do direito privado há dever jurídico tanto de prevenção, como de precaução.

Realizada a digressão no âmbito civil e consumerista, a seguir, caminha-se para a compreensão dos deveres no âmbito axiomático-constitucional, nesta seara compreendido como deveres fundamentais, como justificativa para a atuação da Responsabilidade Civil Preventiva.

A responsabilidade jurídica, observada sob um ângulo dilatado, já que envolve classificações pertencentes a cada ramo do Direito (civil, penal, tributária, administrativa, individual, coletiva etc.), tem fundamento na articulação normativa e axiológica dos deveres fundamentais.

Inicialmente, cabe observar que a categoria jurídica dos deveres fundamentais é inclusa no constitucionalismo cooperativo ${ }^{402}$ e pós-moderno, contudo sem o mesmo prestígio doutrinário dispensado aos direitos fundamentais. Uma possível razão ao pouco interesse despertado para o aprofundamento dos deveres fundamentais é suscitado:

Os deveres. por conseguinte. são antes de tudo impopulares e então difíceis porque existem como uma censura aos direitos: na verdade direitos e deveres podem ser considerados reciprocamente ligados somente em alguns e importantes casos, mas nem todos, e não é de jeito algum verdade que representam sempre as duas faces de uma mesma moeda. ${ }^{403}$

401. HARTMANN, Ivar Alberto Martins. O princípio da precaução e sua aplicação no direito do consumidor: o dever de informação. Revista de direito do consumidor. Vol. 70. Abril-Junho 2009. São Paulo: Revista dos Tribunais, 2009, p.172.

402. HARBELE, Peter. Estado constitucional cooperativo. Trad. Marcos Augusto Maliska e Elisete Antoniuk. Rio de Janeiro: Renovar, 2007.

403. LOMBARDI, Giorgio. I doveri costituzionali: alcune osservazioni. In: R. Balduzzi, M. Cavino, E. Grosso e J. Luther (Coord.). I doveri costituzionali: la prospettiva del giudice delle legge. Torino: G. Giappichelli, 2007, p.569. Tradução livre. Em língua original: "I doveri dunque sono anzitutto impopolari e poi sono ostici perché esiste come una cesura tra essi e i diritti: infatti diritti e doveri possono essere considerati reciprocamente legati solo in alcuni e importanti casi ma non in tutti, e non è affatto vero che rappresentino sempre le due facce di una stessa medaglia". 
No Estado Liberal, os deveres constitucionais eram mitigados e mais comumente tocados à defesa do Estado e ao recolhimento de impostos, base para a estruturação e funcionamento estatal, mas ao mesmo tempo causa subjacente, respectivamente, dos direitos de liberdade e propriedade. A chegada do Estado Social, de outro lado, ao mesmo tempo em que atribuíram direitos mais relevantes de acessibilidade ao cidadão, de outro deslocou deveres para o Estado e reciprocamente à sociedade. Esses deveres podem ser exemplificados como: escolaridade obrigatória; educação dos filhos por parte dos pais; cultivo e exploração do solo; exercício de funções públicas não remuneradas; prestação de serviço ao Estado. ${ }^{404}$

Neste contexto, não tardou para que a tímida figura dos direitos subjetivos públicos $^{405}$ alcançasse a ampla dimensão dos direitos fundamentais, através do corte epistemológico proposto pelo constitucionalismo contemporâneo, acentuadamente baseado nos direitos humanos e na própria força normativa.

O panorama constitucional-axiomático, gradativamente, vai se modificando a partir de novo marco teórico, o neoconstitucionalismo, com ampliação da jurisdição constitucional e o realce de uma nova hermenêutica, a partir do relacionamento dos princípios e regras frente aos valores, na valorização da argumentação jurídica e no compromisso com a teoria da justiça. ${ }^{406}$

Essa reconfiguração propiciou, em consequência, avanços doutrinários que ampliam o cenário e constroem um perfil polifacético da constituição, porque agora ela está baseada em diversos elementos, conforme ressalta José Afonso da Silva, ${ }^{407}$ a saber: $a$ ) orgânico (regulação da estrutura do Estado e Poder); b) limitativo (criação de normas que consubstanciam direitos e garantias fundamentais); c) sócio ideológico (estabelecimento de critérios normativos de equilíbrio entre o Estado personalista e o Estado solidário); d)

404. NABAIS, José Casalta. O dever fundamental de pagar impostos: contributo para a compreensão constitucional do Estado fiscal contemporâneo. Coimbra: Almedina, 2009, p.48-52.

405. JELLINEK, George. Sistema dei diritti pubblici subbiettivi. Trad. G. Vitagliano. Milano: Società Editrice Libraria, 1912.

406. BARROSO, Luís Roberto. Neoconstitucionalismo e constitucionalização do direito: o triunfo tardio do direito Constitucional do Brasil. In: SOUZA NETO, Cláudio Pereira de; SARMENTO, Daniel (Coord.). A constitucionalização do direito: fundamentos teóricos e aplicações específicas. Rio de Janeiro: Lumen Juris, 2007, p.208.

407. SILVA, José Afonso da. Curso de direito constitucional positivo. São Paulo: Malheiros, 2003, p.44. 
estabilização constitucional (fixação de normas para resolução de conflitos constitucionais e de defesa da constituição); e) formais de aplicabilidade (normas que indicam quais das disposições constitucionais têm aplicabilidade imediata).

Contudo, a novidade metodológica mais expressiva quanto ao objeto desta pesquisa e sua influência na Responsabilidade Civil Preventiva dizem respeito ao novo telos constitucional, porque se antes as funções proporcionadas remontavam tão somente à defesa e ao estabelecimento de programas, o modelo vigente agora revela tarefas para a sua ampla eficácia, especialmente no campo social, a serem cumpridas pelo Estado: a) função procedimental ou institucional; b) função de prestação stricto sensu; e por fim, c) função protetiva. $^{408}$

Neste ponto, cabe uma séria reflexão: se a própria Constituição Federal, considerada o vértice do sistema jurídico, assumiu novas funções capazes de conferir efetividade aos valores ali positivados enquanto princípios e regras, como limitar a responsabilidade civil apenas ao campo da reparação, deixando de reconhecê-la demais atribuições que promovam a pessoa humana e ao mesmo tempo amplie o instituto para o porvir na convivência social?

Ora, a conclusão não poderia ser outra senão a de que a responsabilidade civil ampliou o seu campo de atuação, posto que agora também vise à consecução dos deveres fundamentais.

Portanto, os deveres são fundamento da responsabilidade, especialmente nos lindes do direito privado, até porque:

[...] há que ter em conta a concepção de homem que subjaz às actuais constituições, segundo a qual ele não é um mero indivíduo isolado ou solitário, mas sim uma pessoa solidária em termos sociais, constituindo precisamente esta referência e vinculação sociais do indivíduo - que faz deste um ser ao mesmo tempo livre e responsável - a base do entendimento da ordem constitucional assente no princípio da repartição ou da liberdade como uma ordem simultânea e necessariamente de liberdade e de responsabilidade, ou seja, uma ordem de liberdade limitada pela responsabilidade. Enfim, um sistema que confere primazia, mas não exclusividade, aos direitos face aos deveres fundamentais ou,

408. ALEXY, Robert. Teoría de los derechos fundamentales. Trad. Carlos Bernal Pulido. Madrid: Centro de Estúdios Constitucionales, 2007, p.430. 
socorrendo-nos de K. Stern, um sistema em que os direitos fundamentais constituem a essência da liberdade e os deveres fundamentais o seu correctivo. ${ }^{409}$

E justamente a partir deste entendimento, ressalta-se a importância dos deveres para afirmação dos direitos fundamentais. A título de ilustração, há o destaque ao chamado dever de proteção (Schutzpflicth), através do qual ao Estado é conferida a obrigação de prestar fato ou norma que garanta a respeitabilidade de convívio entre as pessoas em sociedade. A considerar a grande participação do setor privado (para não dizer monopolística) no manejo de ciência e tecnologia, obviamente impõe-se o dever de intervenção do Estado para o equilíbrio das posições jurídicas. ${ }^{410}$

A partir de todo o exposto, importante ainda, estabelecer que os deveres fundamentais encontrem justificação no princípio da solidariedade (art. $3^{\circ}$, inc. I, $\mathrm{CF} / 88),{ }^{411}$ que estabelece parâmetros para a atuação da responsabilidade civil, isto porque, "a pessoa é inseparável da solidariedade: ter cuidado com o outro faz parte do conceito de pessoa". ${ }^{412}$ É irrefutável a constatação de que há um comando, uma direção a seguir no referido dispositivo constitucional, atingindo indistintamente a todos que estiverem submetidos à ordem jurídica brasileira (os particulares e o Estado). Trata-se de uma norma finalística e prospectiva que encontra na responsabilidade civil um excelente instrumento de promoção. Também Carla Amado Gomes, ${ }^{413}$ destaca que a figura dos deveres fundamentais, assenta-se na lógica da solidariedade responsável inerente ao Estado Social,

409. NABAIS, José Casalta. O dever fundamental de pagar impostos: contributo para a compreensão constitucional do Estado fiscal contemporâneo. Coimbra: Almedina, 2009, p.31.

410. GRIMM, Dieter. A função protetiva do Estado. In: SOUZA NETO, Cláudio Pereira de; SARMENTO, Daniel (Coord.). A constitucionalização do direito: fundamentos teóricos e aplicações específicas. Rio de Janeiro: Lumen Juris, 2007, p.158.

411. Em idêntico sentido tempos a posição de SARLET, Ingo Wolfgang; FENSTERSEIFER, Tiago. Deveres fundamentais ambientais: a natureza de direito-dever da norma jusfundamental ambiental. Revista de Direito Ambiental. Ano 17. Vol. 67. p. 11-70. Jul.set. / 2012, p. 13-14: "Tal cenário jurídico-constitucional, especialmente naquilo em que está delineado para a tutela ecológica, encontra forte justificação no (e guarda íntima relação com o) princípio (e dever) constitucional de solidariedade, sem prejuízo das possibilidades no campo da assim designada eficácia do direito (mais propriamente, do complexo de direitos e deveres) fundamental à proteção e promoção do ambiente nas relações entre particulares, o que, no seu conjunto, e diante do quadro de risco existencial imposto pela degradação ecológica, impõe maior carga de responsabilidade no que diz com as ações e omissões dos particulares (pessoas físicas e jurídicas) que, de alguma forma, possam, mesmo que potencialmente em face da aplicação do princípio e dever de precaução - comprometer o equilíbrio ecológico".

412. ${ }^{412}$ PERLINGIERI, Pietro. O direito civil na legalidade constitucional. Trad. Maria Cristina De Cicco. Rio de Janeiro: Renovar, 2008, p.461.

413. Risco e modificação do acto autorizativo concretizador de deveres de proteção do ambiente. Lisboa: Edição da autora, 2012, p.151. 
o que traz ao domínio da responsabilidade civil a assunção de uma perspectiva de reconhecimento da dignidade do outro, bem como de colaboração ativa para a promoção dos interesses sociais, que não se restringe ao âmbito individual e presente, mas alcança também uma solidariedade intergeracional.

No âmbito ambiental, a professora portuguesa assim expressa quanto aos deveres ambientais:

Esta nossa construção pressupõe, no entanto, a existência de deveres (de protecção do ambiente) por causa do exercício de direitos (de circulação, de propriedade, de investigação científica). Ou seja, sobretudo na presença de obrigações de facere, o raciocínio implica que o dever de protecção do ambiente - cuja configuração concreta depende da(s) actividade(s) desenvolvida(s) pelo sujeito - , emerja como contrapartida do exercício de determinados direitos. Não significa isto que o dever de protecção do ambiente seja correlativo de um direito com o mesmo objecto - já vimos que essa orientação é de rejeitar. Trata-se, isso sim, de verificar uma ligação incindível entre uma responsabilidade individual de uso racional de um bem de uso colectivo e a pretensão jurídica de levar a cabo determinadas actividades que, pela sua incidência ambiental, requerem cuidados mais ou menos acrescidos. ${ }^{414}$

Importante destacar, portanto, que os deveres não são tocados tão somente em face do Estado. Por vezes, a Constituição conclama a sociedade, a família, e bem dizer a todos os indivíduos numa consecução axiológico-normativa negativa: o respeito incondicional à dignidade da pessoa, pois é um valor indisponível para frear o poder e a prepotência dos outros. E neste contexto, há ligação direta com o campo obrigacional, pois o desrespeito aos deveres fundamentais gera o rebaixamento do fundamento maior do direito: a pessoa. Esta, como membro de uma ordem jurídica, não pode ser tomada apenas como sujeito de direitos, mas sim funcionalmente como condição de existência dessa mesma ordem. ${ }^{415}$

É de Karl Larenz a concepção do personalismo ético, ou seja, a relação de respeito mútuo que cada um deve a qualquer outro e pode exigir deste, reciprocamente. Trata-se da "relação jurídica fundamental", que constitui a base de toda a convivência na

414. GOMES, Carla Amado. Risco e modificação do acto autorizativo concretizador de deveres de proteção do ambiente. Lisboa: Edição da autora, 2012, p.129.

415. Assim nos posicionamos em outro trabalho: FERREIRA, Keila Pacheco. Abuso do direito nas relações obrigacionais. Belo Horizonte: Del Rey, 2007, p. 96. 
comunidade jurídica e de toda a relação jurídica em particular:

[...] el personalismo etico atribuye al hombre, precisamente porque es "persona" en sentido etico, un valor en sí mismo - y, en este sentido, una "dignidad". De ello se sigue que todo ser humano tiene frente a cualquier otro el derecho a ser respetado por él como persona, a no ser perjudicado en su existencia (la vida, el cuerpo, la salud) y en ámbito proprio del mismo y que cada individuo esta obligado frente a cualquier otro de modo análogo. La relación de respeto mutuo que cada uno debe a cualquier otro y puede exigir de éste es la "relacion juridica fundamental", la cual, según esta concepción, es la base de toda convivencia en una comunidad juridica y de toda relación jurídica en particular. Los elementos esenciales de esta relación jurídica fundamental son el derecho (la pretensión justificada) y el deber, así como la reciprocidad de los derechos y deberes en las relaciones de las personas entre sí. ${ }^{416}$

O conteúdo material da dignidade da pessoa impõe que esta seja considerada como um ser integrado à natureza, cuja nota específica reside na "capacidade do homem de sair de si, reconhecer no outro igual, usar a linguagem, dialogar e, ainda, principalmente, na sua vocação para o amor, como entrega espiritual a outrem", na sensível definição de Antônio Junqueira de Azevedo. ${ }^{417}$ Para o prestigiado professor, este princípio possui como pressuposto absoluto, ou seja, "imperativo jurídico categórico", a intangibilidade da vida humana, confirmado pelo caput do art. $5^{\circ}$ da $\mathrm{CF} / 88$. A seu turno, como "imperativos jurídicos relativos", ou seja, preceitos que "embora fundamentais, na sua qualidade de requisitos mínimos para o desenvolvimento da personalidade e procura da felicidade, não são imperativos radicais", são enumeradas as consequências do referido princípio: a) o respeito à integridade física e psíquica; b) o respeito às condições materiais mínimas para o exercício da vida; c) o respeito aos pressupostos mínimos de liberdade e convivência igualitária entre os homens.

Por esta razão, a não observância dos deveres fundamentais encontra junto às funções fragmentadas da responsabilidade civil e o reconhecimento da função preventiva prospectiva um caminho seguro para a implementação. Nessa perspectiva é possível visualizar uma reação ao inadimplemento constitucional, conforme ressalta:

416. Derecho civil: parte general. Trad. e notas de Miguel Izquierdo y Macías-Picavea. Madrid: Revista de Derecho Privado, 1978, p. 45-46.

417. Caracterização jurídica da dignidade da pessoa humana. Revista dos Tribunais. n. 797. p. 11-26. mar./2002. 
Las obligaciones constitucionales, entonces, son en muchísimos casos - por de pronto, cuando resultan correlaticas de derechos - de capital importancia, porque son las que ayudan a que esos derechos funcionen en la dimensión sociológica (con vigencia sociológica) dentro del mundo jurídico. Si la obligación no se cumple, si no se puede compeler a que se cumpla, si el incumplimiento irreparable no se sanciona, el derecho insatisfecho queda burlado. De modo, pues, que resaltar la trascendencia fundamental de las obligaciones constitucionales que frente al titular de los derechos tienen los sujetos pasivos, es una forma imprescindible de realimentar el movimiento ecuménico por los derechos de la persona humana. ${ }^{418}$

Diante de todas as considerações acima estabelecidas, entende-se que a Responsabilidade Civil Preventiva está assentada sob o paradigma da fundamentalidade, qual seja, a imposição de deveres fundamentais que encontram fundamento constitucional: no aspecto individual, o personalismo, considerada a dimensão existencial da pessoa, e o dever de proteção de sua dignidade e personalidade, bem como, no âmbito coletivo, a solidariedade, ${ }^{419}$ com o consectário dever de respeito ao homem das presentes e futuras gerações, ao planeta e aos recursos naturais, em razão dos riscos gerados pela sociedade atual.

Evoluindo nestas considerações, percebe-se que o paradigma da fundamentalidade aqui proposto também se justifica diante da consideração de que determinados bens, para além da classificação tradicional atribuída pelo Código Civil, em seus arts. 79 a 103, merecem ressignificação em razão do conteúdo fundamental que expressam. Ocorre que as transformações do meio social impõem novas necessidades, o que torna a atribuição de importância a determinados bens modificável consoante à época

418. BIDART CAMPOS, German J. Las obligaciones en el Derecho Constitucional. Buenos Aires: Ediar, 1987, p.10.

419. Maria Celina BODIN DE MORAES ressalta o emprego do princípio da solidariedade aos direitos de "terceira geração": "Neles, aglora uma concepção de solidariedade que é resultante de um anseio típico do século XX, quando pela primeira vez o homem se deparou com a hipótese da destruição do planeta e do esgotamento dos recursos naturais: o sentimento de estarmos, todos nós, "a bordo de um mesmo barco", fustigado por ameaças e tribulações globais que nos fazem, necessariamente, solidários uns aos outros. Estes sérios perigos, criados, na maior parte dos casos, pelo próprio homem e por uma (tecno) ciência que vem se perdendo nos excessos de um alegado progresso, geraram um novo dever, para o qual nossos antecessores não destinaram qualquer atenção: o respeito às gerações futuras. [...] Como consequência, aumento em muito o interesse pelo princípio da precaução, que visa a uma maior reflexão antes da utilização de técnicas novas quando o contexto é de incerteza científica. Anteriormente levado em conta apenas em matérias ambiental, hoje já se defende uma aplicação mais ampla, a ser observada por todos aqueles que detêm o poder de decisão sobre o manejo dos riscos". O Princípio da Solidariedade. Disponível em: <http://www.idcivil.com.br/pdf/biblioteca9.pdf>. Acesso em: 18 jul./2013. 
vivida. Assim, importante ficar consignado que a noção aqui estabelecida leva em conta o conceito jurídico de bens, ${ }^{420}$ que podem ser tanto valores materiais, como também imateriais, que servem de objeto a uma dada relação jurídica, não caracterizada, portanto, por um conteúdo material ou patrimonial.

Diante do personalismo e da solidariedade previstos como valores constitucionais, a ordem jurídica deve tutelar bens inestimáveis em conteúdo patrimonial. Luigi Ferrajoli, nesta ótica, propõe uma redefinição do conceito de bens - na tipologia bens fundamentais:

[...] os bens cuja acessibilidade é garantida a todos e a cada um porque objeto de outros tantos direitos fundamentais e que por isso, da mesma forma que estes, são subtraídos à lógica do mercado: o ar, a água e outros bens do patrimônio ecológico da humanidade e, ainda, os órgãos do corpo humano, os fármacos considerados "essenciais" ou "salvavidas" e similares [...] qualquer bem que seja objeto de um direito fundamental primário. ${ }^{421}$

Os bens fundamentais, por sua vez, observam uma tripla categorização bens personalíssimos; bens comuns; bens sociais - consoante definição:

a) os bens personalíssimos, que são objeto de direitos passivos consistentes unicamente em rígida imunidade ou "liberdade da" sua violação, sua apropriação ou utilização por parte de outros: como os órgãos do corpo humano cuja integridade perfaz um todo com a salvaguarda da pessoa e da sua dignidade; b) os bens comuns, que são objeto de direitos ativos de liberdade consistentes, além de imunidade de devastação e saque, também em faculdade ou "liberdade de" isto é, no direito de todos de aceder ao seu uso e gozo: o ar, o clima e os outros bens ecológicos do planeta, de cuja tutela depende o futuro da humanidade; c) finalmente, os bens sociais, que são objeto de direitos sociais à subsistência e à saúde garantidos pela obrigação da sua prestação: a água, os alimentos básicos e os assim chamados "medicamentos essenciais". 422

O conteúdo expresso pelos bens fundamentais é dotado de uma vitalidade tal que, ainda na lição do jurista italiano, deveriam ser estabelecidas "Cartas constitucionais" e "Cartas internacionais dos bens fundamentais", idôneas para impor

420. BEVILÁQUA, Clóvis. Código Civil dos Estados Unidos do Brasil Comentado. v.1. 6 ${ }^{\mathrm{a}}$ ed. Rio de Janeiro: Francisco Alves, 1940, p. 267.

421. Por uma carta dos bens fundamentais. Trad. Daniela Cademartori e Sergio Cademartori. Sequência, $\mathrm{n}^{\circ}$ 60, p. 29-73, jul. 2010, p. 35.

422. FERRAJOLI, Luigi. Op. cit., p. 39. 
limites rigorosos ao mercado e ao desenvolvimento industrial. ${ }^{423}$

Ora, conforme já tratado nos capítulos anteriores, a partir da assunção dos princípios da precaução e da prevenção, com efetivo valor normativo como integrante do sistema de responsabilidade civil, através do diálogo entre diferentes fontes normativas, entende-se que a proteção eficiente dos bens fundamentais deverá ocorrer a partir do modelo de Responsabilidade Civil Preventiva, e portanto, o ordenamento jurídico brasileiro possui os mecanismos necessários para impor os necessários deveres de segurança e proteção aos poderes privados ou públicos, disciplinando lhes o exercício de seus direitos e liberdades, e assegurar a proteção em relação a danos com relação às referidas categorias de bens.

Conclui-se, portanto, com a afirmação de que a Responsabilidade Civil Preventiva justifica-se no paradigma da fundamentalidade - de deveres fundamentais impostos pelo personalismo e solidariedade, e de bens fundamentais cuja nota de essencialidade reclama a atuação de todas as esferas jurídicas para efetividade de sua proteção, quer em relação aos bens personalíssimos (dimensão individual), quer em relação aos bens comuns ou sociais (dimensão coletiva).

423. FERRAJOLI, Luigi. Op. cit., p. 37. O exemplo utilizado é esclarecer: "Um ato de venda da liberdade de consciência ou de manifestação do pensamento, por exemplo, seria irrealizável e sem sentido, dado que as normas que estabelecem tais liberdades são normas heterônomas cuja existência é independente de qualquer coisa que possamos pensar ou fazer. Pelo contrário, a venda ou destruição de um bem fundamental são fatos, talvez irreversíveis [...]”. 


\section{CAPÍTULO 3. INCIDÊNCIA DA FUNÇÃO PREVENTIVA PROSPECTIVA ATRAVÉS DOS CAMPOS NORMATIVOS DOS ILÍCITOS CIVIS}

Já foi visto que, através de uma abordagem funcionalista, é possível estruturar um modelo com capacidade teleológica para absorver os princípios da precaução e da prevenção. Essa postura, bastante diferenciada da tradição positivista, abre caminho para uma série de alterações e questionamentos dogmáticos, cujo reflexo é sentido na engrenagem interna dos pressupostos da responsabilidade civil.

Guido Alpa recorda que há um núcleo comum na estrutura conceitual em cada ordenamento e em cada época histórica do referido instituto, que seriam: a) a qualificação da ação (ou omissão) geradora de responsabilidade; b) produção de dano; c) correlação entre o comportamento e o dano (nexo de causalidade); d) sanção (punitiva, compensatória, ressarcitória). Contudo, o jurista italiano afirma que as variações e evolução da responsabilidade civil demonstram que, na atualidade, essa estrutura é cambiante, pois não é mais imprescindível a presença concomitante desses quatro pressupostos ou elementos para a obrigação de indenizar:

Pode haver, de fato, uma responsabilidade que não deriva de comportamentos (por exemplo, a responsabilidade objetiva do fabricante); é possível que não exista a correlação estreita ou causal; o dano pode ser hipotético, futuro, condicional; a responsabilidade pode existir independentemente de dano (quando possui natureza puramente sancionatória). ${ }^{424}$

Igualmente, Mário Júlio de Almeida Costa, ao questionar qual o futuro da responsabilidade civil, analisa que "caminha-se mesmo mais longe, admitindo que, à semelhança da culpa, o dano não constitua um seu pressuposto necessário". 425

A complexidade e a heterogeneidade de situações novas percebidas em

424. Tradução livre. La responsabilità civile. Parte Generale. Torino: Utet Giuridica, 2010, p.33. Em língua original: "Si può avere infatti una responsabilità che non discende da comportamenti (es. la responsabilità oggetiva del fabbricante); può mancare la correlazione stretta o causale (è il caso della responsabilità casuale o stocastica); il danno può esse ipotetico, futuro, condizionale; la responsabilità può sussistere senza danno (quando abbia natura puramente sanzionatoria)."

425. Direito das obrigações. 7. ed. rev. e atual. Coimbra: Almedina, 1999, p.462. 
tempos de pós-modernidade e proliferação de riscos, resistem ao emprego de uma interpretação de cariz retrospectivo da responsabilidade civil. A pressão dos fatos (riscos certos e incertos de repercussão indesejada e preservação da condição existencial da pessoa humana) e as novas orientações do direito (garantir a expectativa de segurança com a imposição de deveres e a proteção de bens fundamentais) conduzem a repensar a dogmática estabelecida.

Para que se caminhe nesse sentido evolutivo, não é necessária a modificação legislativa do corpo de regras que compõem a responsabilidade civil. Isto porque, os conceitos jurídicos indeterminados sobre as quais se assentam o instituto (como culpa, risco, abuso do direito, dano, nexo causal, equidade etc.) são dotados de plasticidade, e permitem que sejam forjados inovadores padrões de referência, desde que o intérprete se permita reconhecer que novos problemas sociais demandam novas respostas e soluções.

A linguagem jurídica estabelecida no Código Civil é baseada no emprego de cláusulas gerais, o que permite tanto a conexão intra-sistemática, ou seja, entre as normas inseridas em seu próprio texto, quanto à ligação inter-sistemática, como por exemplo, entre o Código e a Constituição, como também extra-sistemática, remetendo o intérprete para fora do sistema jurídico, com a aspiração de concretizar certo valor, ${ }^{426}$ sobretudo considerando o emprego do diálogo das fontes, consoante já ressaltado neste trabalho. A partir desta característica, Renan Lotufo afirma que o Código Civil é capaz de dar efetividade às regras consubstanciadas na Constituição:

Estamos diante de um Código que não quer ser uma Constituição, não quer ser o centro, e sim um corpo de normas com cláusulas abertas para servir e viabilizar a atuação de todo o Direito privado [...] dando margem a uma leitura do Direito Civil que, se não mais se centraliza no Código, por necessária uma leitura à luz dos preceitos elevados à Carta Maior, não deixa de ter a sua importância no dia-a-dia do cidadão comum brasileiro, como mecanismo intermediário necessário à eficaz atuação dos dispositivos necessariamente genéricos dos princípios e valores fundantes. Evidente que tais inovações não são suficientes, mas sem dúvida representam um avanço significativo para uma melhor

426. MARTINS-COSTA, Judith. O novo Código Civil brasileiro: em busca da "ética da situação". In: BRANCO, Gerson Luiz Carlos; MARTINS-COSTA, Judith. Diretrizes teóricas do novo Código Civil brasileiro. São Paulo, Saraiva, 2002, p.98. 
efetividade dos valores constitucionais. ${ }^{427}$

A cláusula geral constitui uma técnica legislativa, uma formulação de preceitos legais por meio de formas vagas e multissignificativas, conforme concepção de Karl Engisch ${ }^{428}$, que abrange uma grande generalidade de hipóteses, em contraposição ao método casuístico, que é uma técnica de regulamentação por fattispecie, ou seja, por tipificação de fatos e condutas. O método casuístico é apontado como o principal fator de rigidez e envelhecimento dos códigos civis, enquanto às cláusulas gerais é assinalada a vantagem da mobilidade.

A interação entre o meio social e a responsabilidade civil deve ser dinâmica e comunicativa, de implicação mútua, sob pena desta se transformar em mera categoria formal e de reduzida capacidade reflexiva. Para tanto, referida técnica legislativa colabora para que o instituto seja um instrumento para promoção de valores.

Supervalorizar a reparação pecuniária para a solução dos conflitos atuais torna-se anacrônico em tempos pós-modernos, diante da capacidade autodestrutiva que o próprio desenvolvimento lançou sob a humanidade, bem como a irreparabilidade de certos danos. Portanto, com o escopo de manter a necessária adequação do instituto às novas realidades, é necessário o estabelecimento de uma teleologia diferenciada, cuja orientação reside no paradigma da fundamentalidade - imposição de deveres fundamentais que se apoiam no personalismo e solidariedade, bem como proteção de bens fundamentais (personalíssimos, comuns ou sociais) - como critério norteador para aplicação da Responsabilidade Civil Preventiva.

Tradicionalmente, a configuração dos ilícitos civis esteve associada à culpa, ao dano e ao dever de indenizar, reconhecendo-se, mais tarde, a possibilidade de ilícitos civis não culposos, e até mesmo a responsabilidade por atos lícitos. A evolução histórica demonstra que o desenvolvimento social e as transformações tecnocientíficas, aliados à funcionalização do direito, permitem que se atribua a estas estruturas normativas uma feição aberta e permeável a valores expressos não apenas por meio de regras, mas também

427. Da oportunidade da codificação civil e a Constituição. In: SARLET, Ingo Wolfgang (Org.). O novo Código Civil e a Constituição. Porto Alegre: Livraria do Advogado, 2003, p.26.

428. Introdução ao pensamento jurídico. Trad. J. Baptista Machado. Lisboa: Fundação Calouste Gulbenkian, 2001, p. 228-229. 
por princípios, que servem de base material para a sua configuração. Desta feita, os princípios da precaução e da prevenção permitem o estabelecimento de novas referências conceituais, em franca transformação dogmática e remodelação hermenêutica.

Com efeito, as cláusulas gerais atuantes no domínio da responsabilidade civil, perspectivadas sob a ótica da Sociedade de Riscos, ostentam uma permeabilidade que lhes permitem incorporar referências axiológicas veiculadas pela precaução e prevenção, de forma heterogênea, múltipla e inédita (se tomada como referência à interpretação tradicional), conferindo primazia à projeção humana em variadas dimensões - segurança, saúde e qualidade de vida nos aspectos individual ou coletivo das gerações atuais ou futuras.

Seja diante de danos de considerável dimensão e gravidade, seja diante de danos que mitigam a potencialidade do ser humano em sua personalidade, a função reparatória da responsabilidade civil ostenta feição meramente paliativa. De tal aspecto, resulta inadmissível que o preenchimento do conteúdo dos campos normativos do instituto seja neutro e formal. O intérprete deve, outrossim, partir para a busca de uma feição substancial, no contexto da sociedade hiper-complexa da atualidade.

Desta feita, em consideração à função preventiva prospectiva ditada por necessidades sociais, aos pressupostos da responsabilidade civil é reconhecida uma feição multiforme, o que possibilita o seu emprego tanto no domínio da responsabilidade civil reparatória, como na preventiva. O que varia, na verdade, é o conteúdo substancial adotado para a formação de critérios de imputação, conforme situação fática apresentada, e não a estrutura formal dos elementos. E como já foi dito, é o paradigma da fundamentalidade (deveres e bens) o critério norteador que reclama a atuação da Responsabilidade Preventiva.

Enfim, a construção dessa nova experiência interpretativa, cujo ponto de partida é a absorção dos princípios da precaução e da prevenção, reconfigura os domínios da ilicitude civil, dos nexos de imputação, do dano, do nexo de causalidade, e projeta a responsabilidade civil como um sistema que atende funções variadas e opera mediante modelos retrospectivo e prospectivo, em tutelas reparatórias e preventivas. Com este enfoque, será abordada, em sequência, a possibilidade de modulação da função preventiva prospectiva através dos campos normativos dos ilícitos civis. 


\subsection{A PRECAUÇÃO E A PREVENÇÃo COMO PARÂMETROS PARA A AVALIAÇÃO DA CONDUTA EXÍGÍVEL - ART. 186, CC}

A responsabilidade civil subjetiva (também denominada culposa, aquiliana, ou por atos ilícitos) é a obrigação de reparar danos patrimoniais ou extrapatrimoniais causados por ação ou omissão, dolosos (intencionais) ou culposos (negligência, imprudência, imperícia), que violem direitos alheios, consoante redação consolidada no art. 186 do Código Civil. Exige, portanto, como requisitos: a) conduta (ação ou omissão) violadora de direito; b) dano; c) nexo de causalidade entre a conduta e o dano; d) culpa.

Dos elementos apontados, é sobre a culpa que os princípios da precaução e prevenção vão apresentar alguma relevância, consoante análise a seguir.

Não existe na legislação brasileira uma definição normativa de culpa. Doutrinariamente, conforme lição de Mazeaud e Chabas, "la culpa es un error de conducta tal que no hubiera sido cometido por una persona prudente, colocada en las mismas circunstancias 'externas' que el demandado". ${ }^{429}$ A seu turno, Marcelo Junqueira Calix to a define como "erro de conduta, imputável ao agente, consistente em não adotar o cuidado que teria sido adotado pelo ser humano prudente nas circunstâncias do caso concreto". ${ }^{43}$

É a culpa elemento indispensável, na responsabilidade subjetiva, para que se estabeleça o nexo de imputação entre o dano ocasionado e o responsável. ${ }^{431}$ Para tanto, exprime um juízo de reprovabilidade da conduta, pressupondo que em face das circunstâncias específicas do caso, o autor do dano devia e podia ter agido de modo diverso. Contudo, como estabelecer um parâmetro acerca da conduta, ou, em outras palavras, qual seria o grau de diligência exigível em situações concretas?

429. MAZEAUD, Henri; MAZEAUD, León; MAZEAUD, Jean; CHABAS, François. Derecho civil. Obligaciones. Tomo II. Traducción de Luis Andorno. Buenos Aires: Zavalia, 2006, p. 48.

430. CALIXTO, Marcelo Junqueira. A culpa na responsabilidade civil: estrutura e função. Rio de Janeiro: Renovar, 2008, p. 31.

431. NORONHA, Fernando. Direito das obrigações. Vol. 1. São Paulo: Saraiva, 2003, p. 472: "Nexo de imputação é o fundamento, ou a razão de ser da atribuição da responsabilidade a uma determinada pessoa, pelos danos ocasionados ao patrimônio ou à pessoa de outra, em consequência de um determinado fato antijurídico. É o elemento que aponta o responsável, estabelecendo a ligação do fato danoso com este". 
A resposta à indagação passa pelo debate acerca da culpa apreciada $\mathrm{em}$ abstrato, e em concreto. Para a primeira vertente, há uma obrigação legal de agir com prudência e diligência em todos os atos e atividades, sem qualquer consideração acerca das condições especiais da pessoa, o seu grau de compreensão, ou possibilidades individuais. O parâmetro de comparação é o homem normal, que age de modo uniforme na sociedade em determinadas circunstâncias. De outro lado, a culpa concreta é aquela cuja apreciação leva em consideração a consciência do responsável, o seu íntimo. ${ }^{432}$

Em situações complexas e plurais, típicas da sociedade pós-moderna, a definição de um padrão único de diligência, seja em abstrato ou em concreto, não tem sido considerada a forma mais racional de avaliação. ${ }^{433}$ Nestes casos, não se defende o retorno à avaliação subjetiva e moral da conduta, contudo, fomenta-se uma "fragmentação do modelo de conduta", ${ }^{434}$ que avalie as especificidades das situações apresentadas, de acordo com parâmetros externos que ofereçam standards como paradigma.

Assim, é possível verificar que a culpa standard corresponde à violação de um padrão de conduta exigível, seja intencionalmente ou não. Os "Princípios de Direito Europeu de Responsabilidade Civil", ${ }^{435}$ estabelecidos pelo European Group on Tort Law, indicam critérios capazes de direcionar a avaliação da conduta exigível e orientar a sua delimitação:

Art. 4: 102. Padrão de conduta exigível. (1) O padrão de conduta exigível corresponde ao de uma pessoa razoável colocada nas mesmas circunstâncias e depende, especialmente, da natureza e valor do interesse protegido em questão, da periculosidade da actividade, da perícia que é de esperar da pessoa que a exerce, da previsibilidade do dano, da relação de proximidade ou da particular confiança entre as partes envolvidas, bem como da disponibilidade e custos de métodos preventivos ou alternativos. (2) O padrão de conduta

432. LIMA, Alvino. Culpa e Risco. $2^{\text {a }}$ ed. rev. e atual. por Ovídio Rocha Barros Sandoval. São Paulo: Editora Revista dos Tribunais, 1999, p. 59.

433. Diogo L. Machado de MELO observa que: "Mesmo após diversos estudos, propugnando o avanço do conceito - não mais psicológico, mas normativo - baseado em standards de conduta, tornando a culpa mais objetiva, entende-se que há muito ainda a ser esclarecido, ainda mais diante da função da responsabilidade atual e das próprias exigências da vida em sociedade". Culpa extracontratual: uma visita, dez anos depois. In: LOTUFO, Renan; NANNI, Giovanni Ettore; MARTINS, Fernando Rodrigues. Temas relevantes do direito civil contemporâneo: reflexões sobre os 10 anos do Código Civil. São Paulo: Atlas, 2012, p. 604.

434. SCHREIBER, Anderson. Novos paradigmas da responsabilidade civil: da erosão dos filtros da reparação à diluição dos danos. São Paulo: Atlas, 2007, p. 40-41.

435. Disponível em: <http://civil.udg.edu/php//index.php?id=129>. Acesso em: 11 out./2013. 
pode ser ajustado em função da idade, de deficiência psíquica ou física, ou quando, devido a circunstâncias extraordinárias, não se possa legitimamente esperar que a pessoa em causa actue em conformidade com o mesmo. (3) As disposições que prescrevem ou proíbem uma determinada conduta devem ser tomadas em consideração a fím de se estabelecer o padrão de conduta exigível.

Obviamente, a avaliação a priori do que seria a conduta exigível em determinada circunstância, à míngua de elementos concretos, não é possível de se realizar. Contudo, os critérios apontados acima indicam pistas que contém certa relevância para a prevenção do dano, tais como "periculosidade da atividade", "previsibilidade", “confiança entre as partes”, “disponibilidade de métodos preventivos". Nestes aspectos é que reside a aproximação da conduta culposa com a criação de riscos intoleráveis, por inobservância dos deveres de precaução ou de prevenção.

Mário Barcellona, ${ }^{436}$ em análise acerca da concepção standard de culpa e sua pertinência com relação ao risco criado, estabelece que seja justamente aquela o critério apto a fornecer as informações relevantes, por sua vez obtidas através de um "método" de reconstrução do caso concreto em função do problema a solucionar. Este juízo inicialmente isola e organiza o caso segundo uma técnica tópica (identificação do risco do qual decorre o dano, determinação das condições de sua ocorrência etc.) e posteriormente emprega-se uma avaliação deôntica, destinada a determinar qual é a tolerabilidade do risco criado.

Ao proceder referida conjectura, os princípios da precaução e da prevenção poderiam reforçar a noção de culpa, através de uma interpretação amplificada. ${ }^{437}$

Importante ressaltar que não é a criação de qualquer risco o parâmetro determinante para a conduta culposa, mas sim a verificação, diante das circunstâncias concretas, se o risco criado ultrapassou os limites de tolerabilidade, fixados de acordo com

436. Tratatto della responsabilità civile. Torino: Utet Giuridica, 2011, p. 250. No original: "Lo standard della colpa è, per l'appunto, deputato a fornire questo necessario supplemento di conoscenza e consistem propriamente in un giudizio che si avvale di un "metodo" di ricostruzione del caso concreto in funzione del problema da risolvere per mezzo del quale il caso è isolato e organizzato secondo una tecnica topica (determinazione del rischio di cui il danno è attuazione, delle condizioni della sua insorgenza, ecc.) e che si basa sul succesivo trattamento del caso così ricostruito secondo un misuratore deontico (inteso a determinare la tollerabilità del rischio creato).

437. Assim: LOPEZ, Teresa Ancona. Princípio da Precaução e Evolução da Responsabilidade Civil. São Paulo: Quartier Latin, 2010, p.143 et seq; VINEY, Geneviève. Traité de Droit Civil: Introduction à la responsabilité. $3^{\mathrm{e}}$ éd. Paris: LGDJ, 2008, p. 156. 
cada atividade ou produto especificamente considerados. ${ }^{438}$

Com relação à prevenção, se o risco era certo e conhecido, e ainda assim não foram tomadas as medidas necessárias para o seu gerenciamento e controle, e em decorrência, o dano se verificou, a conclusão acerca da presença de culpa não oferece maior dificuldade.

Já a precaução, por incidir em hipóteses incertas e desconhecidas, terá influência no fato do responsável não ter avaliado (risk assessment) as dimensões do risco que não estava totalmente identificado no momento em que o comportamento do autor do dano é apreciado. Mais que isso, a par da avaliação insuficiente, decorre que o autor do dano não implementou as medidas de precaução exigíveis na hipótese concreta (risk management), especialmente considerando bens fundamentais como a saúde e o meio ambiente. E por fim, também não informou adequadamente a potencialidade danosa do risco (risk communication). Recorde-se que não se trata de um cenário imaginário, mas sim de um risco que, embora dotado de incerteza científica, pode ser estimado como plausível conforme o conhecimento até então estabelecido.

Assim, esta ausência de precaução poderia ser considerada uma falta da conduta exigível na situação verificada, caracterizando, portanto, uma conduta culposa. Não é o caso de responsabilizar o autor do dano por não conseguir antecipar os riscos cujos contornos concludentes sequer estão disponíveis conforme o estado da ciência, mas sim de realizar uma avaliação retrospectiva, com o escopo de verificar o cumprimento de medidas preventivas cuja expectativa era legítima que fossem implementadas, a fim de evitar a ocorrência de danos.

Essa avaliação quanto à implementação de medidas preventivas poderá repercutir, ainda, com relação ao quantum debeatur, ou medida da indenização, através de uma avaliação equitativa a ser realizada pelo juiz, no caso do gestor do risco ter agido com

438. Patrícia Iglecias Faga LEMOS esclarece que qualquer ação humana é capaz de gerar impacto no meio ambiente, o que exige a fixação de limites de tolerabilidade. Contudo, ressalta, ainda, que a elaboração de padrões de qualidade pelo Poder Público (por exemplo, emissão de poluentes na siderurgia) podem ser tomadas com base apenas em imperativos tecnológicos ou interesses próprios, o que não impede, portanto, que uma atividade que cumpra os termos da licença (portanto, cumpre o requisito da legalidade) acarrete o dever de responder pelo dano configurado. Mudanças climáticas e responsabilidade civil por dano ao meio ambiente. In: LAVRATTI, Paula Lavratti; PRESTES, Vanêsca Buzelato. Direito e mudanças climáticas [recurso eletrônico]. São Paulo : Instituto O Direito por um Planeta Verde, 2010, p.63. 
graduações mais ou menos elevadas de precaução ou prevenção, e estas se apresentarem manifestamente desproporcionais ao dano verificado, conforme autoriza o art. 944, parágrafo único, do Código Civil.

\subsection{O ABUSO DO DIREITO DEMARCADO PELOS DEVERES DE PRECAUÇÃO E DE PREVENÇÃO - ART. 187, CC}

Também a figura do abuso do direito, prevista no art. 187 do Código Civil, é capaz de absorver os reflexos impostos pelos deveres de precaução e de prevenção.

Embora tenha sido estabelecido como uma espécie de ato ilícito pelo Código Civil de 2002, o abuso de direito é modalidade estruturalmente distinta daquela anteriormente analisada, positivada em seu art. 186. Cumpre, neste momento, estabelecer as suas distinções.

A origem do abuso do direito aponta para o seu reconhecimento jurisprudencial, antes mesmo de expressa previsão legislativa, anunciando a atenuação do caráter absoluto dos direitos subjetivos. ${ }^{439}$ A consolidação doutrinária, por sua vez, obteve consagração em face da teoria finalista de Louis Josserand, segundo a qual o exercício dos direitos subjetivos deveria cumprir o fim a que se destinam, o motivo legítimo, ou a sua missão, por constituírem-se como direitos-função. ${ }^{440}$

439. MENEZES CORDEIRO, António. Da boa-fé no direito civil Coimbra: Almedina, 2001, p. 671. Com efeito, atribui-se aos tribunais franceses as primeiras decisões fundamentadas a partir dessa figura, ainda no início de vigência do Code Napoleon: condenação de um proprietário de oficina de chapéus que provocava evaporações desagradáveis para a vizinhança (1808); construtor de um forno que por ausência de precauções gerava danos ao vizinho (1820); construção de falsa chaminé com o intuito de obstar que a luz do dia através alcançasse um imóvel através da janela (1913), bem como a elevação de espigões de ferro destinados a danificar os dirigíveis que sobrevoavam determinada propriedade (1915).

440. JOSSERAND, Louis. De l'esprit des droits et de leur relativité. Paris: Librairie Dalloz, 1927, p. 371: “(...) en réalité, et dans une société organisée, es prétendus droits subjectifs sont des droits-fonction (3); ils doivent demeurer dans le plan de la fonction à laquelle ils correspondent, sinon leur titulaire commet um détournement, um abus de droit; l'acte abusif est l'acte contraire au but de l'institution, à son esprit et à sa finalité”. (...) “Cette cohésion du système apparaîtra plus nettement encore si, pénétrant jusqu'à l'essence même des droits subjectifs, nous les classons, d'après l'esprit qui lês anime, em trois catégories: $1^{\circ}$ Les droits non causes; $2^{\circ}$ Les drois à esprit égoiste; $3^{\circ}$ Les droits à esprit altruiste". 
Nas primeiras elaborações acerca do abuso do direito, de caráter subjetivista, o mesmo permanecia vinculado à culpa, com manifesto propósito de prejudicar o lesado (ato emulativo), não lhe sendo reconhecida autonomia dogmática em relação ao ato ilícito. As considerações objetivas só começaram a dominar o cenário jurídico a partir da elaboração de Josserand, acima mencionada, ao considerar abusivo o desvio de finalidade. ${ }^{441}$

A evolução das concepções que buscam um critério identificador do ato abusivo aponta na direção de que este venha a ser revelado por um elemento valorativo interno do direito subjetivo, ou seja, o abuso passa a ser compreendido como o exercício de um direito em desconformidade com o seu valor, que é um componente do conteúdo deste direito, e constitui o seu próprio limite. Trata-se das construções axiológiconormativas do abuso do direito, que rompem com a teoria finalista de Josserand, pois esta ainda preservava, de certa forma, uma concepção absoluta do direito subjetivo, pois a sua finalidade social (política, ideológica ou econômica) permanecia em um plano metajurídico. $^{442}$

A partir da compreensão de que o abuso do direito deve ser assimilado como uma violação de valores que a norma jurídica procura realizar, é possível destacar a característica autônoma da categoria, que a distingue do ato ilícito.

Assim, no abuso de direito, há o preenchimento da estrutura formal, uma aparência de direito, do qual se é titular. Já no ato ilícito observa-se a violação do limite formal estabelecido pela lei. Nas duas hipóteses, estará presente a antijuridicidade (ato contrário ao ordenamento jurídico). Contudo, a ilicitude é identificada na violação de um direito subjetivo alheio, ou de uma disposição de lei que proteja direitos alheios. Já na

441. Mário Júlio de Almeida COSTA faz a distinção: “A Teoria Subjetiva considera decisiva a atitude psicológica do titular do direito, o ter ele agido com o único propósito de prejudicar o lesado (acto emulativo). Centra-se o problema na intenção do agente. Para a Teoria Objetiva, ao invés, o que interessa averiguar não é a intenção do agente, mas os dados do facto, o alcance objetivo do seu comportamento, de acordo com o critério da consciência pública. Uma fórmula vulgarizada pelos objectivistas consiste em considerar abusivo o uso antifuncional do direito". Direito das Obrigações. $7^{\mathrm{a}}$ ed. Coimbra: Almedina, 1999, p. 69.

442. Seja permitido fazer referência ao nosso estudo anterior, para uma consulta mais aprofundada acerca das concepções axiológico-normativas do abuso de direito, a partir dos autores de Carlos Fernandez Sessarego, Virgilio Giorgianni, António Castanheira Neves e Fernando Augusto Cunha de Sá. FERREIRA, Keila Pacheco. Abuso do direito nas relações obrigacionais. Belo Horizonte: Del Rey, 2007, p.29 et seq. 
abusividade haverá violação dos valores que sustentam materialmente o direito. ${ }^{443}$

Proposta ainda mais avançada merece ser destacada. A autonomia do abuso do direito, na atualidade, não se verifica apenas com relação ao ato ilícito, mas também com relação ao próprio direito subjetivo, pois alcança uma série de outras prerrogativas individuais que não se enquadram na moldura estabelecida por aquele, tais como liberdades, faculdades, direitos potestativos etc. Qualquer que seja a posição jurídica estabelecida, o seu fundamento axiológico haverá de ser observado, sob pena de caracterizar-se o que Menezes Cordeiro ${ }^{444}$ denomina "exercício inadmissível de posições jurídicas", que representam disfuncionalidades perante o sistema jurídico, espelhado no exemplo alemão que faz referência à boa-fé, e recebe categorização típica nas figuras da exceptio doli, venire contra factum proprium, suppressio, surrectio, tu quoque entre outras.

A partir da constatação de que o conceito de ato ilícito não se confunde com o de culpa, pode-se observar que o Código Civil brasileiro estabelece duas categorias: o ato ilícito subjetivo (art. 186), já exposto anteriormente; e ato ilícito consubstanciado no abuso do direito (art. 187), que independe de culpa e fundamenta-se no critério objetivofinalístico. $^{445}$

Estabelecidos os contornos contemporâneos do abuso do direito, bem como a sua distinção com ato ilícito, resta demonstrar em que medida os princípios da precaução e da prevenção podem influenciar a sua caracterização.

O abuso do direito é modelado juridicamente a partir de critérios a serem mensurados no caso concreto, referidas pelo texto legal: o fím econômico ou social do direito, a boa-fé e os bons costumes. Além disso, o art. 187 do Código Civil permite compreender o ato abusivo como categoria independente da existência de dano.

443. FERREIRA, Keila Pacheco. Abuso do direito nas relações obrigacionais. Belo Horizonte: Del Rey, 2007, p. 37.

444. MENEZES CORDEIRO, Antônio Manuel da Rocha e. Da boa-fé no direito civil Coimbra: Almedina, 2001, p. 661.

445. LOPEZ, Teresa Ancona. Principais linhas da responsabilidade no direito brasileiro contemporâneo. In: AZEVEDO, Antônio Junqueira de; TÔRRES, Heleno Taveira; CARBONE, Paolo. Princípios do novo Código Civil brasileiro e outros temas. Homenagem a Tullio Ascarelli. São Paulo: Quartier Latin, 2008, p. 666. 
É por este caminho - ilicitude sem dano, que os deveres de precaução e de prevenção ingressam na delimitação do abuso do direito, ao estabelecer medidas ao exercício de prerrogativas jurídicas, que devem se conformar com os princípios normativos em que se fundam, predispostos no ordenamento jurídico. Com este entendimento, a professora portuguesa Mafalda Miranda Barbosa estabelece a dialética entre liberdade e responsabilidade:

[...] o exercício de uma liberdade, entendida nos moldes explicitados, é abusivo sempre que a pessoa omita os deveres de prevenção do perigo predispostos - e emergentes na realidade concreta - para fazer face a uma situação de perigo. Efectivamente, o entendimento actual da liberdade implica a correlativa responsabilidade na medida em que o conteúdo do direito é, também conformado por uma série de deveres. Se o abuso do direito implica a desconformidade do seu exercício com um princípio normativo em que aquele se funda, não podemos deixar de considerar que o exercício de uma liberdade se mostra abusivo quando viole um princípio da precaução ou da prevenção, inscrito na dialéctica liberdade vs. responsabilidade. Efectivamente, a liberdade que se postula é a liberdade em sentido positivo, que acarreta deveres de solidariedade para com os demais membros da comunidade. Daí se afirmar que ela é indissociável da responsabilidade. A uni-las, dialecticamente, encontramos essa noção de prevenção ou precaução, actualizada face a concretas situações de perigo. ${ }^{446}$

No mesmo sentido, também Maria da Glória F.P.D. Garcia:

O sentido do agir humano no novo paradigma ético, que não é só sagacidade perante a situação ambiental mas respeito para com todos e cada um dos membros da comunidade, abre caminho ao novo paradigma do direito, no qual a prevenção e os deveres de cuidado são condicionantes internas do exercício dos direitos de liberdade". ${ }^{447}$

Portanto, compreendida a ilicitude do art. 187 como o exercício de um direito - portanto, a princípio, lícito em seu aspecto formal - que ultrapasse os limites estabelecidos no mesmo dispositivo, pode-se afirmar que o não cumprimento dos deveres de precaução e de prevenção e a consequente produção de riscos (além dos limites toleráveis), caracterizam-se como uma forma de excesso manifesto dos fins sociais e dos deveres de proteção (anexo à boa-fé), cuja observância é imposta pela norma.

446. Liberdade vs. Responsabilidade: a precaução como fundamento da imputação delitual? Coimbra: Almedina, 2006, p. 406.

447. O lugar do direito na proteção do ambiente. Coimbra: Almedina, 2007, p. 487. 
A ilicitude compreendida no abuso do direito, assim, estará caracterizada quando, no gerenciamento dos riscos certos ou incertos, a dimensão dos danos ocasionados e a necessidade de preservação de bens fundamentais reclamarem a atuação de medidas preventivas, nas hipóteses não verificadas.

O risco, conforme já foi demonstrado ao longo deste trabalho, é uma realidade com a qual a sociedade pós-moderna não escapa. O que se exige, entretanto, é encontrar formas de gerenciar e conviver com os riscos. Para tanto, a legislação deverá fornecer elementos que permitam a adequação do perfil variável dos mesmos na disciplina de suas normas.

O tratamento jurídico conferido ao risco enfrenta duas alternativas. A primeira, diz respeito à possibilidade de aplicar ao mesmo as tutelas inibitórias ou de remoção, no intuito de cercear-lhe a possibilidade de causar dano (objeto da análise do subcapítulo 3.3, infra). A segunda, estabelece um alargamento no conceito de dano, para considerar que o risco, em si mesmo, pode ser objeto de indenização (tema analisado no capítulo 4, infra).

Cabe neste ponto uma observação. Uma vez verificado o abuso do direito, e considerando que o ilícito já estará configurado, (por violação dos valores veiculados pela precaução e prevenção, desatendendo os fins sociais e os deveres de proteção), caberá buscar a sua cessação, para que o risco a que a sociedade já está exposta não venha a provocar repercussões mais graves. Não se trata, obviamente, da aplicação de uma tutela reparatória do dano, tampouco de uma tutela inibitória do risco, e sim de uma tutela de remoção, ou cessação, do próprio ilícito. É justamente a relação entre a responsabilidade civil e as tutelas preventivas a partir da distinção entre dano e ilícito, o tema abordado a seguir. 


\subsection{DISTINÇÃO ENTRE ILÍCITO E DANO PARA APLICAÇÃO DAS TUTELAS DE CONTROLE DO RISCO: A RESPONSABILIDADE CIVIL COMO SISTEMA}

A distinção teórica entre ato ilícito e dano não oferece grandes dificuldades: ato ilícito é simplesmente o ato contrário ao direito, e dano (ou fato danoso) é o prejuízo juridicamente relevante. ${ }^{448}$

No item 3.2, supra, quando foi abordado o ato ilícito consubstanciado no abuso do direito, verificou-se que a figura contida no art. 187 do Código Civil prescinde da existência de dano para a sua caracterização. Cumpre recordar que no direito positivo brasileiro existem, além do mencionado ato abusivo, outras hipóteses de ilicitude civil sem dano efetivo. Cite-se algumas possibilidades: a violação de domicílio, é ilícita, pois o direito de propriedade foi violado, porém, o dano não é indispensável; a turbação e o esbulho; a ameaça de lesão aos direitos da personalidade, ao meio ambiente, e ainda, no domínio da bioética. ${ }^{449}$

No Código de Defesa do Consumidor, também há ilicitude civil sem dano, no caso das previsões acerca da publicidade enganosa e abusiva. Em referidos casos, o direito à indenização decorre de previsão expressa do art. $6^{\circ}$, inciso VI, do CDC, que normatiza como direito básico do consumidor "a efetiva prevenção e reparação de danos patrimoniais e morais, individuais, coletivos e difusos". A respeito, Lucia Ancona Lopez de Magalhães Dias afirma que se trata: “[...] de sistemática fundada na teoria do risco do empreendimento e que requer apenas a comprovação do nexo causal entre a ação ou omissão do agente (veiculação de comunicação publicitária ilícita) e o dano gerado, ainda que em sua potencialidade." 450

Teresa Ancona Lopez, a seu turno, compreende que o Código de Defesa do

448. SARLET, Ingo Wolfgang; MARINONI, Luiz Guilherme; MITIDIERO, Daniel. Curso de direito constitucional. São Paulo: Editora Revista dos Tribunais, 2012, p. 638.

449. MARTINS-COSTA, Judith. Os campos normativos da boa-fé objetiva: as três perspectivas do direito brasileiro. In: JUNQUEIRA DE AZEVEDO, Antonio; TÔRRES, Heleno Taveira; CARBONE, Paolo (coord). Princípios do Novo Código Civil Brasileiro e Outros Temas: homenagem a Tullio Ascarelli. São Paulo: Quartier Latin, 2008, p. 411.

450. Publicidade e direito. São Paulo: Editora Revista dos Tribunais, 2010, p. 280. 
Consumidor, admitindo punição à publicidade enganosa, está adotando a responsabilidade sem dano, ou seja, "aquele que veicula esse tipo de publicidade está obrigado à reparação pelo risco de enganosidade criado, mesmo que não haja vítimas". ${ }^{451}$

Inevitável, pois, a conclusão de que o dano é um componente eventual do ilícito civil, e embora se reconheça que o mesmo está presente em grande parte das situações que reclamam a atuação da responsabilidade, a sua ocorrência não se afigura indispensável. $^{452}$

Portanto, é possível identificar ato ilícito que depende da existência de dano para a sua configuração (art. 186, CC), ato ilícito que prescinde da existência de dano (art. 187, CC - abuso do direito) e também danos que decorrem de atos lícitos. ${ }^{453}$ Isto demonstra que ato ilícito e dano são categorias que guardam absoluta autonomia.

Quando a distinção entre ilícito e dano é identificada, abre-se espaço para a busca de tutela de direitos que não cabem adequadamente na via ressarcitória. Luiz Guilherme Marinoni expõe a problemática:

A associação de ilícito e dano deriva da suposição de que a violação do direito somente pode exigir do processo civil tutela contra o dano - na forma específica ou pelo equivalente monetário -, mas jamais uma tutela voltada a remover o ilícito (independentemente de ele ter provocado dano). Ou ainda: tal associação se funda na falsa premissa de que o processo civil não pode impedir a violação de um direito sem se importar com a probabilidade de dano. Frise-se que inibir a violação não é o mesmo que inibir o dano. Além disso, do ponto de vista probatório, é muito mais fácil caracterizar o ilícito ou sua ameaça do que precisar o

451. LOPEZ, Teresa Ancona. Principais linhas da responsabilidade no direito brasileiro contemporâneo. In: AZEVEDO, Antônio Junqueira de; TÔRRES, Heleno Taveira; CARBONE, Paolo. Princípios do novo Código Civil brasileiro e outros temas. Homenagem a Tullio Ascarelli. São Paulo: Quartier Latin, 2008, p. 703 (nota de rodapé 78).

452. BRAGGA NETO, Felipe Peixoto. Teoria dos ilícitos civis. Belo Horizonte: Del Rey, 2003, p. 84.

453. Teresa Ancona LOPEZ menciona que "a teoria do risco trata da responsabilidade pela atividade lícita". Principais linhas da responsabilidade no direito brasileiro contemporâneo. In: AZEVEDO, Antônio Junqueira de; TÔRRES, Heleno Taveira; CARBONE, Paolo. Princípios do novo Código Civil brasileiro e outros temas. Homenagem a Tullio Ascarelli. São Paulo: Quartier Latin, 2008, p. 679. Patrícia Faga Iglecias LEMOS exemplifica com o caso do empreendedor ter uma licença e desenvolver atividade dentro dos limites desta, e mesmo assim, poderá ser responsabilizado sempre que o meio não absorver seus impactos. In: LAVRATTI, Paula Lavratti; PRESTES, Vanêsca Buzelato. Direito e mudanças climáticas [recurso eletrônico]. São Paulo : Instituto O Direito por um Planeta Verde, 2010, p.64. 
dano ou sua probabilidade. ${ }^{454}$

Ora, se a autonomia entre as categorias ilicitude e dano é reconhecida a partir da própria legislação, é possível estabelecer uma conexão sistemática entre esta e as regras processuais, desmistificando a noção de que a responsabilidade civil terá atuação somente em caso de ocorrência de danos. Pode-se até admitir que a indenização dependa da verificação do dano (e em alguns casos o risco em si mesmo considerado já pode ser tratado como dano, conforme ainda será abordado). Porém, a responsabilidade, cuja noção é mais alargada, poderá atuar também em face do gerenciamento dos riscos, e correspondente emprego da tutela inibitória e de remoção do ilícito.

A constatação de que o direito não é um sistema de convivência que se satisfaça com a aplicação de sanções, mas aspira a não ter que usá-las, conduzem Gabriel Stiglitz e Carlos Echevesti a afirmar que a responsabilidade civil não esgota o seu modo de atuação no âmbito estritamente ressarcitório, mas ao contrário, traz ínsita uma ampla capacidade regulatória, endereçada também à prevenção de danos. Neste passo, caberia à indenização ressarcitória uma prevenção indireta, no sentido dissuassório, e às técnicas inibitórias, a prevenção direta. Referidos autores são enfáticos:

Particularmente, insistimos que la prevención es funcion del Derecho de Daños, através de la justicia civil, que extiende sus poderes de control para ejercer una efectiva suplencia, cuando la actuación de la Administración (del Derecho Público) se revela insuficiente para evitar perjuicios en la sociedad. ${ }^{455}$

A efetividade da tutela jurisdicional é um direito fundamental assegurado pelo art. $5^{\circ}, \mathrm{XXXV}$, da Constituição Federal, nela prevista a apreciação tanto de lesão, como também de ameaça a direito. Portanto, o direito à tutela preventiva para o impedimento da violação de direito deverá ser assegurado de forma mais ampla possível, não apenas processualmente, haja vista que o direito à tutela inibitória, em diversas situações, está contido na própria estrutura da norma que institui o direito, como é exemplo o art. 12 do Código Civil, cuja análise mais detida será efetuada no subcapítulo a seguir. Assim, Luiz Guilherme Marinoni ressalta que:

454. MARINONI, Luiz Guilherme. Técnica processual e tutela dos direitos. $3^{\mathrm{a}}$ ed. São Paulo: RT, 2010, p. 122.

455. STIGLITZ, Gabriel A.; ECHEVESTI, Carlos A. Responsabilidad civil. In: ITURRASPE, Jorge Mosset. (Dir.); CARLUCCI, Aida Kemelmajer de. (Coord.). Buenos Aires: Hammurabi, 1997, p. 510. 
[...] o direito à inibição do ilícito está no plano do direito material, pois decorre da sanção que compõe a própria norma que outorga o direito, e não na esfera do direito processual. $\mathrm{O}$ processo é somente técnica para a prestação da tutela inibitória, pois essa última já é garantida pelo direito material. No entanto, se o processo, diante da natureza de algumas situações de direito substancial, não estiver disposto de modo a viabilizar a outorga da tutela inibitória àquele que a ela tem direito, certamente estará negando o direito fundamental à tutela jurisdicional preventiva. ${ }^{456}$

A aplicação das variadas tutelas em face do ato ilícito, do risco e do dano deverá observar uma dimensão temporal. Se a ilicitude ainda não se configurou, ou seja, se não ocorreu qualquer violação à norma, porém há uma probabilidade de concretização de um ilícito, cabível será a tutela inibitória. Aqui, por ser antecedente à prática de qualquer ilícito, esta tutela é verdadeiramente preventiva. De outro lado, se o ato ilícito já ocorreu, é necessário verificar se a eficácia do mesmo perdura no tempo ou não. Em caso afirmativo, será o caso de tutela de remoção (ou cessação) do ilícito. Porém, se do ato ilícito já decorreu o dano, a hipótese será de tutela ressarcitória. ${ }^{457}$

Quanto à cessação do ilícito, especificamente, e empregando uma dimensão material, Cyril Bloch ${ }^{458}$ eleva a categoria ao status de função típica da responsabilidade civil extracontratual, tão autônoma e essencial quanto às funções reparatória e punitiva. Segundo esta posição, está compreendida no âmbito da responsabilidade civil a possibilidade de desencadear medidas corretivas para o restabelecimento da licitude, quando estiver em causa um fato possível de gerar um dano prestes a se concretizar, ou que já esteja em curso. Assim, ao fazer cessar a origem do possível dano (o ilícito que gera risco), é reconhecida a esta função uma maneira eficaz de atuação preventiva, capaz de impedir a ocorrência de danos futuros. Geneviève Viney ${ }^{459}$ ao comentar referido

456. MARINONI, Luiz Guilherme. Técnica processual e tutela dos direitos. $3^{\mathrm{a}}$ ed. São Paulo: RT, 2010, p. 141.

457. TESSLER, Luciane Gonçalves. Tutelas jurisdicionais ao meio ambiente: tutela inibitória, tutela de remoção, tutela do ressarcimento na forma específica. São Paulo: Editora Revista dos Tribunais, 2004, p. 240 .

458. La cessation de l'illicite: recherche sur une fonction méconnue de la responsabilité civile extracontractuelle. Paris: Dalloz, 2008, p. 30: "Cette vocation de la sanction juridique à remplir directement l'aspiration essentielle de toute règle de droit à être obéie par ses destinataires irradie l'ensemble de notre droit. A côté de la peine et de la réparation, semble se dégager une troisième catégorie de sanctions, irréductible aux deux précédentes: la céssation de l'illicite, dans laquelle pourrait être rangé l'ensemble des sanctions juridiques ayant pour objet de mettre l'acte ou le fait illicite en conformité avec la règle de droit violée".

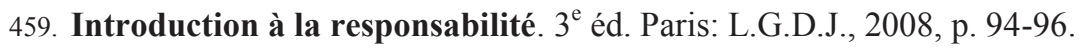


entendimento, aduz que a autonomia em relação à função reparatória, defendida por Cyril Bloch no tocante à cessação do ilícito, não a divorcia do sistema da responsabilidade civil. $^{460}$

Portanto, a responsabilidade civil contemporânea, ao assumir novas funções, deve ser compreendida como um sistema que abrange todas as medidas necessárias para a tutela dos riscos, seja de maneira retrospectiva, seja prospectiva, visando impedir a ocorrência de danos. Essa visão sistemática da responsabilidade civil, inclusive, é o norte da elaboração do "Proyecto de Codigo Civil y Comercial de La Nacion", na Argentina, elaborado sob a presidência de Ricardo Luis Lorenzetti. ${ }^{461}$ Com apoio nesta convicção, as considerações expostas neste tópico abrem o caminho para que a análise do art. 12 do Código Civil possa identificar neste dispositivo uma cláusula geral de responsabilidade preventiva.

\subsection{CLÁUSULA GERAL DE RESPONSABILIDADE CIVIL PREVENTIVA NA TUTELA DAS SITUAÇÕES JURÍDICAS SUBJETIVAS EXISTENCIAIS - ART. $12, \mathrm{CC}$}

Grande parte da doutrina nacional ao tratar do caput do art. 12 do Código Civil atribui-lhe a figura de tutela inibitória de natureza processual. Considerando que os fundamentos de promoção e de proteção constante do referido dispositivo são direitos de personalidade - direitos sensiveis e diferenciados - opta-se por outro caminho, mais ousado, no entanto, consentâneo aos valores ali tutelados, ampliando as potencialidades da responsabilidade civil. Daí, exsurge a convicção de que há cláusula geral de

460. Em posição diversa, Daniel de Andrade Levy. Responsabilidade civil: de um direito de danos a um direito das condutas lesivas. São Paulo: Atlas, 2012, p. 156: “Aqui, uma função preventiva da 'Responsabilidade Civil' nada mais seria do que uma medida de cunho procedimental, pela qual o magistrado poderá ordenar a imediata cessação da conduta que produz o risco. (...) Por isso é que usamos as aspas no parágrafo acima. O princípio preventivo é totalmente subtraído da disciplina, e se torna norma geral de um campo jurídico mais amplo."

461. Disponível em: <http://www.nuevocodigocivil.com/pdf/Texto-del-Proyecto-de-Codigo-Civil-yComercial-de-la-Nacion.pdf $>$. Acesso em: 20 out./2013. 
Responsabilidade Civil Preventiva no sistema, consoante justificativas que seguem

Inicia-se no campo zetético, onde transparece mais tranquila a referência aos direitos da personalidade, para posteriormente explicitar a preferência em expandi-los em “situações jurídicas subjetivas existenciais”. A junção será metodológica, e abordará o prestígio e as possibilidades da Responsabilidade Civil Preventiva no campo da pessoa situada, do existencialismo.

Em Sêneca já se avistava: "homo homini est sacra" (o homem é coisa sagrada para o homem $).{ }^{462}$ Eis o ponto central filosófico: a pessoa e a sua dignidade.

Após o advento da Constituição Federal, eclodiram na dogmática jurídica brasileira, acompanhando temática outrora já verificada em outros países, diversificados estudos, investigações e publicações, quanto ao fundamento da dignidade da pessoa humana, conforme inciso III, do art. $1^{\mathrm{o}}, \mathrm{CF} .{ }^{463}$ Esse movimento possui base inspiradora na Declaração Universal dos Direitos Humanos, que influenciou e instigou o constitucionalismo atual. ${ }^{464}$ Nesta pesquisa, ${ }^{465}$ já foi explicitado que a responsabilidade jurídica deriva igualmente dos deveres fundamentais, que atuam como correção de direitos de mesmo nível normativo. Destaque-se, no entanto, que a chamada constante do fundamento da dignidade da pessoa contribuiu ao fortalecimento de direitos, sem que a reciprocidade aos deveres fundamentais ocorresse em idêntica intensidade verificada. Contudo, a pessoa e eminente dignidade também são fundamentos dos deveres:

Por detrás do conjunto dos deveres fundamentais está um estado entendido como uma organização e um valor função da pessoa humana, um estado, no fim das contas, instrumento da realização a eminente dignidade humana. ${ }^{466}$

462. ITURRASPE, Jorge Mosset. Interpretación económica del contrato. Santa Fé: Rubinzal-Culzoni, 1994, p.56.

463. Ver por todos duas obras em destaque: BRITTO, Carlos Ayres, O humanismo como categoria constitucional. Belo Horizonte: Fórum, 2007; SARLET, Ingo Wolfgang. Dignidade da pessoa humana e direitos fundamentais na Constituição Federal de 1988. 2. ed. Porto Alegre: Livraria do Advogado Editora, 2002.

464. LAFER, Celso. A reconstrução dos direitos humanos: um diálogo com o pensamento de Hannah Arendt. São Paulo: $4^{\mathrm{a}}$ reimpressão. Companhia das Letras, 2001.

465. Vide Parte 2, capítulo 2.

466. NABAIS, José Casalta. O dever fundamental de pagar impostos: contributo para a compreensão constitucional do Estado fiscal contemporâneo. Coimbra: Almedina, 2009, p.60. 
Note-se que a dignidade, apesar da forte convocação dogmática, é atributo pertencente à pessoa, não estando acima dela. Neste sentido, José de Oliveira Ascensão aprofunda:

Mas a dignidade da pessoa, sucessivamente reafirmada, passou a ser invocada como a base das soluções jurídicas em que a pessoa possa estar implicada. Este recurso foi sendo cada vez mais ampliado. Ao ponto da dignidade da pessoa se tornar justificação suficiente para qualquer causa. O seu campo de incidência ampliou-se. Sem que se sentisse em contrapartida grande necessidade de demonstrar que a dignidade da pessoa humana implicava efetivamente aquela solução. A dignidade, que é um atributo, passou a ser utilizada como uma substância. ${ }^{467}$

Parece de forma clara, e sem tensões, que o fundamento do Direito é a pessoa (substância) que é dotada de dignidade (atributo). Essa vertente pode ser seguida a partir da diferenciação entre homem-pessoa e homem sujeito de direitos. ${ }^{468}$

Perceba-se que o iluminismo, a sociedade tecnológica (de racionalidade instrumental $)^{469}$ e o welfare state, criaram virtualismos humanos; espectros da lei; figuras estanques e diversas na tríade direito-ética-sociedade; indivíduos como entidades meramente antropológicas. De forma definida, cada qual fez, respectivamente, surgir figuras indiferentes: o homo faber, o homo laborans e homo ludens. Ao passo que homempessoa é ser de aquisição axiológica sob perspectiva substancial; ser, sobretudo, ético e responsável, ${ }^{470}$ integrado ao Direito, posto que seu fundamento.

467. ASCENSÃO, José de Oliveira. O fundamento do direito: entre o direito natural e a dignidade da pessoa. Revista da Faculdade de Direito da Universidade de Lisboa. Vol. LII. n ${ }^{\circ} 1$ e 2. p. 29-44. Coimbra: Coimbra Editora, 2011, p.43.

468. FERREIRA, Ana Elisabete. A vulnerabilidade humana e a pessoa para o direito - breves notas. In: Revista do Instituto de Direito Brasileiro. n. 2. Lisboa: Faculdade de Direito da Universidade de Lisboa, 2014, p.1032. Explicita que no iluminismo o homem "que se diz criador do seu direito, é, na verdade, muito menos um 'sujeito de direito' do que um 'sujeito ao direito': o homem iluminista autoriza a sua lei, e porque é ele quem lhe confere autoridade e vigência, julga-se o seu criador e conformador; contudo, este homem torna-se um escravo do direito, um ser que obedece à lei, ainda que a lei seja absurda, pela razão evidente de que a lei é lei, e, portanto, um ser que, em última instância, deve ao direito a sua existência pessoal e social"'.

469. HORKHEIMER, Max. Eclipse da Razão. Rio de Janeiro: Labor do Brasil, 1976.

470. É o caso de Hans JONAS com a ética intergeracional. In: JONAS, Hans. O princípio da responsabilidade: ensaio de uma ética para uma civilização tecnológica. Rio de Janeiro: PUC Rio, 2006, p.69. Arremata: "não temos direito de escolher ou de arriscar a não existência de gerações futuras". 
António Castanheira Neves ${ }^{471}$ justifica as bases desta afirmação:

Tanto o homo faber e também simplesmente laborans da sociedade técnica, como ao homo ludens da sociedade do bem-estar à outrance que esvaziou espiritualmente o homem, pretende-se opor a afirmação do homem-pessoa e com todas as implicações axiológicas e éticas do sentido da pessoa. Se no sentido de pessoa se postula a sua dignidade absoluta ao mesmo tempo em que se nega a sua identificação ao 'indivíduo' e se recusa o individualismo deste, uma vez compreendido o pressuponente compromisso e recíproco reconhecimento comunitários que aquela comunidade implica, significará também isso não apenas a responsabilidade ética perante a pessoa em todo universo humano (seja imediatamente prático e de conveniência ou não) como igualmente a responsabilidade ética da pessoa relativamente mesmo universo. Tanto é dizer que a pessoa não é só sujeito de direitos, sejam eles fundamentais ou outros, mas simultaneamente sujeito de deveres - não sendo os direitos simples reivindicações politicamente sustentadas e os deveres exterioridades limitativas só pelo cogente cálculo de interesses e sempre repudiavelmente sofridos, como acontece com a polarização prática no indivíduo, mas manifestações mesmas de axiologia responsável e responsabilizante da pessoa.

Considera-se homem-pessoa, o humano axiologicamente compreendido e comprometido com o hipercomplexo jurídico, dele compartilhando as estruturas, ambientando as funções, residindo no sistema. Por isso, em semelhante compreensão, a doutrina argentina revela:

O homem, como indivíduo, é apenas outra unidade biológica (o materialismo é consequente ao estimar o homem apenas como animal evoluído). A pessoa é também indivíduo, sem dúvida, porém com hierarquia espiritual: é portadora de valores religiosos, éticos e de cultura em geral e constrói sua vida (apenas conhecida no sentido biológico) sobre tais valores. Tem consciência de si, dos deveres e direitos, é capaz de virtudes generosas e de vícios, de sacrifícios, de crimes e de pecados. Enfim, é responsável (...) É a pessoa, e não o indivíduo, quem está no centro do problema. Com este outro nome, o problema adquire uma súbita lucidez: o Estado se encontra obrigado a tratar os homens como pessoas e, por conseguinte, a respeitar os valores e os direitos essenciais inerentes a sua essência espiritual. $^{472}$

A digressão realizada, com a referência à pessoa no âmbito da filosofia,

471. CASTANHEIRA NEVES, A. Entre o legislador a sociedade e o juiz ou entre sistema função e problema - os modelos actualmente alternativos da realização jurisdicional do direito. Boletim da Faculdade de Direito. V. LXXIV. Coimbra: Coimbra Editora, 1998, p.33.

472. ORGAZ, Alfredo. Las personas humanas: esencia y existência. Buenos Aires: Hammurabi, 2000, p.37. 
permite melhor conhecimento e profundidade com relação aos direitos da personalidade, porque além de evitar o abstracionismo do princípio da dignidade da pessoa, permite a exata perspectiva do "homem situado" na comunidade, ${ }^{473}$ dotado de direitos e responsabilidades. Para a análise dos direitos da personalidade, essa percepção é bastante relevante, porque considera diretamente a pessoa e, entre direitos e deveres, legitima o princípio geral do respeito recíproco ${ }^{474}$ e circunscreve a dignidade como qualidade da pessoa que tem na vida seu maior valor. Antônio Junqueira de Azevedo narra esse raciocínio de forma invulgar:

A vida genericamente considerada consubstancia o valor de tudo que existe na natureza. Esse valor existe por si; ele independe do homem. Do primeiro ser vivo até hoje, há um fluxo vital contínuo; todo ser vivo tem sua própria centelha de vida, mas cada centelha individual surge do fogo que, desde então, queima na Terra e, nesse fogo, cada centelha se insere como parte no todo. A vida em geral fundamenta o direito ambiental e o direito dos animais. Todavia, é, sem dúvida, a vida humana que, sob o aspecto ontológico, representa sua parte excelente. Por isso, a vida humana - globalmente e em cada uma de suas centelhas - deve merecer a maior atenção do jurista. Sob o ponto de vista que nos interessa, isto é, de cada pessoa humana, a vida é condição de existência. O princípio jurídico da dignidade, como fundamento da República, exige como pressuposto a intangibilidade da vida humana. Sem vida, não há pessoa, e sem pessoa, não há dignidade. ${ }^{475}$

Nesta perspectiva, parte-se agora com maior precisão para o conteúdo daquilo que se considera objeto da cláusula geral de Responsabilidade Civil Preventiva, de que trata o art. 12 do Código Civil: os direitos da personalidade.

Os direitos da personalidade são considerados princípio fundamental ${ }^{476}$ na

473. ARENDT, Hannah. Origens do totalitarismo: antissemitismo, imperialismo e totalitarismo. São Paulo: Companhia das Letras, 1989, p.331. Lembra quanto à desconstrução do homem: "Só a perda da própria comunidade é o que o expulsa da humanidade".

474. LARENZ. Karl. Derecho justo: fundamentos de ética juridica. Trad. Luiz Díez-Picazo. Madrid: Civitas, 1991: "El principio del respeto recíproco no encuentra en modo alguno su precipitado sólo en los 'derechos fundamentales', sino que atraviesa todo el ordenamiento jurídico [...] Del derecho general de la personalidade hemos hablado ya. Este derecho protege la personali humana en su inmediato ámbito de existencia, en su fenotipo (su imagem, su proyección en obras literárias o en escenarios), sus manifestaciones (por ejemplo, cartas, diários, palavra hablada) y otras proyecciones dignas de protección".

475. AZEVEDO, Antônio Junqueira de. Caracterização jurídica da dignidade da pessoa humana. Estudos e pareceres de Direito Privado. São Paulo: Saraiva, 2004, p.14.

476. MOTA PINTO, Carlos Alberto da. Teoria geral do direito civil. $4^{\mathrm{a}}$ ed. António Pinto Monteiro e Paulo Mota Pinto (atual.). Coimbra: Coimbra Editora, 2005, p.97. 
teoria geral do direito civil na medida em que a pessoa (e sua aderente dignidade) firma-se como fundamento do sistema jurídico, portanto, constante preocupação promocional da ciência do Direito. Foi ultrapassada, assim, a teoria negativista, para a qual o sujeito de direitos não poderia ser também concomitantemente objeto de direito. ${ }^{477}$

Desta forma, percebe-se que os direitos da personalidade concretizam os valores imanentes, transcendentes e essenciais à pessoa e à necessária promoção no âmbito social (vida, integridade física, honra, imagem, vida privada, privacidade, intimidade, sigilo etc.), ${ }^{478}$ tornando-os dignos de tutela no domínio do direito privado, o que por si, já os diferencia dos direitos fundamentais e direitos humanos. ${ }^{479}$

Com esta observação, é possível afirmar que os direitos da personalidade, nas hipóteses de conflitos normativos no direito privado, possuem forte transcendência e superioridade, já que os demais direitos de categoria privada não desfrutam da mesma base. ${ }^{480}$ Se não são protegidos e defendidos, com o atributo normativo que têm, outros direitos subjetivos, inclusive aqueles de caráter patrimonial, perdem a utilidade. ${ }^{481}$

Por sua vez, a especificação da natureza jurídica dos referidos direitos exige maior aprofundamento. Poderiam ser identificados como direitos subjetivos. Como assinalado, os direitos subjetivos representam a permissão normativa específica de aproveitamento de determinado bem. Desdobra-se em modalidades, inclusive potestativa, se couber apenas a uma das partes modificarem unilateralmente, nos limites da lei, específica atribuição. ${ }^{482}$

Disso decorre o posicionamento de que os direitos da personalidade são

477. GOMES, Orlando. Introdução ao direito civil. 10a ed. Rio de Janeiro: Forense, 1988, p.156.

478. TEPEDINO, Gustavo. A tutela da personalidade no ordenamento civil-constitucional brasileiro. In: Temas de direito civil. Rio de Janeiro: Renovar, 1999, p.25.

479. SCHREIBER, Anderson. Direitos da personalidade. São Paulo: Atlas, 2011, p.13. Geralmente, a atuação dos direitos humanos (supraconstitucionais) dá-se nas órbitas transnacionais, ao passo que os direitos fundamentais (constitucionais) referem-se à relação Estado e cidadão.

480. ASCEnSÃO, José de Oliveira. Direito civil. Teoria geral. As pessoas. Os bens. Vol. 1. São Paulo: Saraiva, 2010, p.59.

481. DE CUPIS, Adriano. Os direitos da personalidade. Trad. Antônio Vera Jardim e António Miguel Caeeiro. Lisboa: Morais Editora, 1961, p.17.

482. MENEZES CORDEIRO, António. Tratado de direito civil português. $3^{\mathrm{a}}$ reimpressão. Coimbra: Almedina, 2007, p.332. 
direitos subjetivos especiais, ${ }^{483}$ assegurando posição de vantagem ao titular. ${ }^{484}$

O modelo da relação jurídica ${ }^{485}$ é configurado pela atribuição ao titular de determinado direito subjetivo (comum ou potestativo), enquanto impõe-se a outra pessoa dever jurídico ou sujeição (intersubjetividade). ${ }^{486}$ Neste ponto, destaca-se uma dificuldade, porque a assimilação dos direitos da personalidade não pressupõe necessariamente vínculo entre dois sujeitos.

Por sua vez, situação jurídica é a condição humana valorada pelo direito, permitindo definição e resolução do caso concreto, considerando as circunstâncias da pessoa frente ao sistema.

Trata-se, portanto, de um entendimento ampliado, com circunferência abrangente da própria relação jurídica, estendendo a inerente atribuição para diversas manifestações de direito (como direitos subjetivos, interesses, poderes, interesse, legitimação, expectativa, deveres e faculdade). ${ }^{487}$

Contudo, ao considerar-se o conteúdo dos direitos da personalidade, a sua inerente natureza jurídica é mais bem absorvida como situação jurídica subjetiva existencial, $^{488}$ que expressa à proteção de determinado interesse de característica não patrimonial, onde as manifestações jurídicas são de ordem pública, indisponíveis, intransmissíveis e irrenunciáveis e conclamam a funcionalização do sistema por meio de

483. CAPELO DE SOUSA, Rabindranath V. A. O direito geral de personalidade. Coimbra: Coimbra Editora, 1995, p.85.

484. ASCENSÃO, José de Oliveira. Direito civil. Teoria geral. As pessoas. Os bens. Vol. 1. São Paulo: Saraiva, 2010, p.67.

485. GALVÃO TELLES, Inocêncio. Introdução ao estudo do direito. v.2 Coimbra, 2001, p.465. Reflete: "relação social tutelada pelo Direito mediante a atribuição dum poder a um dos sujeitos e a imposição dum correspondente dever ao outro".

486. MOTA PINTO, Carlos Alberto da. Teoria geral do direito civil. $4^{\mathrm{a}}$ ed. António Pinto Monteiro e Paulo Mota Pinto (atual.). Coimbra: Coimbra Editora, 2005, p.178.

487. CASTRO, Torquato. Teoria da situação jurídica em direito privado nacional: estrutura, causa e título legitimatário do sujeito. São Paulo: Saraiva, 1985, p.66. Indica: “A ordem jurídica dispõe sobre os problemas da vida, ajustando às situações de fato a situação de direito. A situação jurídica é a expressão última da disposição introduzida pela norma sobre os próprios elementos da situação de fato".

488. PERLINGIERI, Pietro; FEMIA, Pasquale. Nozioni introduttive e principi fondamentali del diritto civile. $2^{\mathrm{a}}$ ed. Napoli: Edizione Scientifiche italiane, 2004, p.121. 
hermenêutica emancipatória. ${ }^{489}$ Em outras palavras, como situação jurídica subjetiva existencial, há maior facilidade em operacionalizar o livre desenvolvimento da pessoa humana, afinal "ninguém pode ser obrigado a anular sua personalidade". 490

Para tutelar toda a dimensão acima exposta, o Código Civil traz o dispositivo contido no art. 12, caput, do qual literalmente se extrai:

Art. 12. Pode-se exigir que cesse a ameaça, ou a lesão, a direito da personalidade, e reclamar perdas e danos, sem prejuízo de outras sanções previstas em lei.

De início, percebe-se que o caput do art. 12 permite: a) autotutela pela vítima; b) tutela preventiva antes da lesão ou do exaurimento total da lesão; c) tutela reparatória, sem prejuízos de outras sanções. ${ }^{491}$

Pois bem. A doutrina, de forma majoritária, tem indicado que a primeira parte do caput do art. 12 do Código Civil refere-se à tutela inibitória de natureza processual. As asserções são várias:

A tutela processual prevista para os direitos de personalidade é ampla. O caput do art. 12 do Código Civil estabelece que a tutela jurídica dos direitos da personalidade deve ser feita para evitar a lesão, para impedir a continuidade da violação e para garantir o ressarcimento dos prejuízos advindos da lesão e a compensação pelo dano extrapatrimonial". 492

489. AZEVEDO, Antônio Junqueira. Natureza jurídica do contrato de consórcio (sinalagma indireto). Onerosidade excessiva em contrato de consórcio. Resolução parcial do contrato. Novos estudos e pareceres de direito privado. São Paulo: Saraiva, 2009, p.356. O Professor das Arcadas, muito embora não tenha concluído texto específico, aborda novo paradigma contratual e a transformação dos princípios dos contratos, especialmente a boa-fé, demonstrando que em outros campos do direito privado a projeção do conceito de pessoa como fundamento do direito foi incisivo para a mudança de rota somente patrimonial. São suas palavras: "Ela, em primeiro lugar, é muito maior entre os contratos que batizamos de contratos existenciais (os de consumo, os de trabalho, os de locação residencial, de compra e venda da casa própria e, de uma maneira geral, os que dizem respeito à subsistência da pessoa humana) do que entre os contratos empresariais. Essa nova dicotomia que defendemos, 'contrato existencial/contrato empresarial', é, a nosso ver, a verdadeira dicotomia contratual do século XXI. Por força da renovação dos princípios contratuais e da frequência de sua concretização, não se pode mais empregar a palavra 'contrato' sem consciência dessa nova dicotomia; ela é operacional e está para o século XXI como a de 'contrato paritário/contrato de adesão' esteve para o século XX”.

490. LORENZETTI, Ricardo Luis. Teoria da decisão judicial: fundamentos de direito. Trad. Bruno Miragem. São Paulo: Revista dos Tribunais, 2010, p.82.

491. SZANIAWSKI, Elimar. Direitos de personalidade e sua tutela. $2^{\text {a }}$ ed. São Paulo: Revista dos Tribunais, 2005, p.248.

492. BRASILEIRO BORGES, Roxana Cardoso. Dos direitos da personalidade. In: LOTUFO, Renan; NANNI, Giovanni Ettore (Coord.). Teoria geral do direito civil. São Paulo, Atlas, 2008. 
Gustavo Tepedino, Heloísa Helena Barboza e Maria Celina Bodin de Moraes $^{493}$ adotam o mesmo entendimento, afirmando que:

O dispositivo reforça os mecanismos de proteção ao momento patológico da violação: além da possibilidade de recurso às medidas cautelares e ao pedido de antecipação de tutela, há que se observar o art. 461 e parágrafos do $\mathrm{CPC}$, referentes às ações que tenham por objeto o cumprimento de obrigação de fazer ou não fazer, e que, entre outros objetivos, pretende constranger o réu.

Sílvio de Sálvio Venosa, ${ }^{494}$ igualmente indica a lei processual para correção das ameaças de lesão:

O Código de Processo Civil fornece instrumentos eficazes para que a vítima obtenha celeremente provimento jurisdicional que faça cessar a ameaça ou lesão a direito personalíssimo. Afora os princípios gerais que disciplinaram a ação cautelar que podem ser utilizados conforme a utilidade e conveniência.

Elimar Szaniawski ${ }^{495}$ adere:

A interdição da perturbação dar-se-á através de tutela inibitória, que além de fazer cessar o atentado atual e contínuo, removendo os efeitos danosos que são produzidos e que se protraem no tempo, possui natureza preventiva contra possível prática de novos atentados pelo mesmo autor. As ações típicas destinadas para tutelar preventivamente a vítima de atos atentatórios ao seu direito de personalidade, consiste na ação inibitória antecipada, na ação de preceito cominatório, da tutela antecipada e das medidas cautelares típicas, como a busca e apreensão e o sequestro, e as medidas cautelares atípicas.

Some-se a isso o Enunciado n ${ }^{\circ} 140$ da III Jornada de Direito Civil:

Enunciado 140 - Art. 12: A primeira parte do art. 12 do Código Civil refere-se às técnicas de tutela específica, aplicáveis de ofício, enunciadas no art. 461 do Código de Processo Civil, devendo ser interpretada com resultado extensivo. ${ }^{496}$

493. TEPEDINO, Gustavo, BARBOZA, Heloísa Helena e MORAES, Maria Celina Bodin de. Código Civil interpretado conforme a Constituição da República. $2^{\text {a }}$ ed. Rio de Janeiro: Renovar, 2007, p.35.

494. VENOSA, Sílvio Sálvio. Direito civil: parte geral. 13ª ed. São Paulo: Atlas, 2013, p.182

495. SZANIAWSKI, Elimar. Direitos de personalidade e sua tutela. $2^{\text {a }}$ ed. São Paulo: Revista dos Tribunais, 2005, p.248.

496. Jornadas de direito civil I, III, IV e V: enunciados aprovados. Ministro Ruy Rosado de Aguiar Júnior (coordenador científico). Brasília: Conselho da Justiça Federal. Centro de Estudos Judiciários, 2012, p.35. 
Longe de polemizar com referidas conclusões, é importante verificar que a dogmática do direito civil deve buscar sustentabilidade nos próprios fundamentos e nos próprios limites. Em outras palavras, é evidente que quando há conflitos pessoais não mediados ou não transacionados, é o Estado-juiz competente para o deslinde, no entanto, entre direito de ação, direito subjetivo e pretensão há diferenças significativas. ${ }^{497}$ Ademais, a pessoa que é titular do direito de personalidade, poderá opor de maneira erga omnes a sua respectiva preservação. Em situações de ameaça ao direito, ou de violação, sucede a pretensão quanto à exigibilidade de respeito (as duas situações subjetivas são existenciais e de direito privado). No entanto, o modo de operar essa pretensão por ameaça ou violação do direito é via judiciário, através de ação específica, cuja natureza é de direito público (direito processual civil).

Aos processualistas ${ }^{498}$ deve ser reconhecido o mérito de indicar novos caminhos para a responsabilidade civil, por vezes vinculado ao dispositivo exposto no caput do art. 12 do Código Civil, com especial relevo para as tutelas inibitórias e de remoção do ilícito, cuja análise já foi exposta no capítulo precedente. No entanto, aqui cabe uma avaliação: se lesão é dano (no sentido de interesse juridicamente tutelável) e se dano mantém autonomia com o ato ilícito, o mencionado dispositivo não parece pressupor que esteja a exigir o filtro exclusivo da ilicitude para ser operacionalizado, até porque violações aos direitos da personalidade podem decorrer de atos excepcionalmente lícitos, como na hipótese de atos justificados com ofensa a terceiros. ${ }^{499}$

De todo o exposto, decorre a conclusão de que a cláusula geral de Responsabilidade Civil Preventiva advém justamente da verificação de tutela inibitória de natureza material em amplo diálogo com a responsabilidade civil por danos extrapatrimoniais e danos (despesas) de prevenção. Importante explicar, separadamente, as duas esferas.

Lhamas Pombo esclarece o âmbito da primeira:

497. PONTES DE MIRANDA, Francisco Cavalcanti. Tratado da ação rescisória. Campinas: Bookseller, 1998, p.34-61.

498. MARINONI, Luiz Guilherme. Tutela inibitória: individual e coletiva. $5^{\text {a }}$ ed. São Paulo: Revista dos Tribunais, 2012, p.39.

499. NORONHA, Fernando. Direito das obrigações. $2^{\mathrm{a}}$ ed. São Paulo: Saraiva, 2007, p.361. 
Dicha tutela inibitória no es nada nuevo en nuestra tradición jurídica, al menos en determinados supuestos típicos (interdictos, acción negatória, abuso del derecho etc.). Sin embargo, es preciso reconstruirla en un tratamento unitário, para aplicarla especificamente a la Prevención del daño con caráter atípico y general". [...]. Por eso, ya no es admisible el viejo mito del monopólio preventivo del Estado y del Derecho administrativo. El Derecho Civil no puede conformarse com la mera respuesta reparadora frente al daño y renunciar la Prevención del mismo. Pretender que permanezca impasible ante la inminencia de un daño, de sua agravación o de su repetición, es tanto como crear y justificar un 'derecho a perjudicar'. 500

Ocorre que essa tutela inibitória, diga-se civil (e, portanto, de natureza material), por si só não contempla a dimensão de promoção dos direitos da personalidade, como direitos sensiveis e diferenciados no direito privado. Isto porque, o dispositivo, justamente pelo conteúdo dos valores em jogo, veda não apenas a continuidade da violação, mas a ameaça.

Ora, corolário da vida digna está o direito ao respeito (direito de ser deixado em paz) ${ }^{501}$ e ao sossego, como órbitas da intangibilidade da pessoa e, via de consequência, a simples exposição a ameaças sérias ou a riscos intoleráveis já configura turbação da tranquilidade do ofendido, ${ }^{502}$ caracterizando lesão a interesse jurídico tutelável, ${ }^{503}$ ou seja, dano extrapatrimonial.

Ademais, o ofendido, na órbita de sua proteção à lesão que quer evitar, poderá realizar despesas para prevenir danos de dimensões mais profundas. Aliás, as despesas de prevenção ${ }^{504}$ já são aceitas na órbita ambiental como elemento do princípio do poluidor-pagador, de que trata o art. $225, \S 3^{\circ}$ da Constituição Federal.

500. POMBO, Eugenio Llamas. Prevención y reparación: las dos caras del derecho de daños. In: La responsabilidad civil y su problemática actual. Juan Antonio Moreno Martínez (Coordinador). Madrid: Dykinson, 2007, p.463.

501. BITTAR, Carlos Alberto. Os direitos da personalidade. $7^{\text {a }}$ ed. Rio de Janeiro: Forense Universitária, 2004, p.13.

502. COSTA, Carlos A. Calvo. Dano resarcible. Buenos Aires: Hammurabi, 2005, p.185.

503. VINEY, Geniviève; JOURDAIN, Patrice. Les condition de la responsabilité. $3^{\mathrm{a}}$ ed. Paris: LDGJ, 2006, p. 14.

504. BENJAMIN, Antônio Hermann Vasconcelos. O princípio do poluidor-pagador e a reparação do dano ambiental. Dano ambiental: prevenção, reparação e repressão. São Paulo: Revista dos Tribunais, 1994, p.228. Salienta a propósito: “o princípio do poluidor-pagador "impõe ao poluidor o dever de arcar com as despesas de prevenção, reparação e repressão da poluição. Ou seja, estabelece que o causador da poluição e da degradação dos recursos naturais deve ser o responsável principal pelas consequências de sua ação (ou omissão)." 
E, por fim, evidenciam-se os danos presumidos, que acompanham os interesses jurídicos lesados no momento do fato (juros, correção monetária e honorários de advogado), como se percebe da segunda parte do art. 389 do Código Civil.

Na consideração dinâmica e sistemática da responsabilidade civil, operando com modelos preventivo e reparatório, é certo que a tutela inibitória material, muito embora impeça a lesão ou seu curso, não resolve a questão atinente aos danos mencionados, e de outro lado, a responsabilidade civil reparatória não consegue evitar o dano e sua continuidade. Por isso, o diálogo é extremamente exitoso para a efetividade dos direitos da personalidade, como forma de promoção da pessoa humana e confirmação da hermenêutica emancipatória.

Por fim, conclui-se que a cláusula geral de tutela da pessoa $^{505}$ não haveria a exata dimensão de tutela, caso não fosse acompanhada da cláusula geral de Responsabilidade Civil Preventiva. Nas palavras de Maria Celina Bodin de Moraes:

A tutela da pessoa humana não pode ser fracionada em isoladas hipóteses, microssistemas, em autônomas fattispecie não intercomunicáveis entre si, mas deve ser apresentada como um problema unitário, dado o seu fundamento, representado pela unidade do valor da pessoa. Esse fundamento não pode ser dividido em tantos interesses, em tantos bens, como é feito nas teorias atomísticas. A personalidade é, portanto, não um "direito", mas um valor, o valor fundamental do ordenamento, que está na base de uma série (aberta) de situações existenciais, nas quais se traduz a sua incessantemente mutável exigência de tutela. ${ }^{506}$

505. MORAES, Maria Celina Bodin de. Danos à pessoa humana: uma leitura civil-constitucional dos danos morais. Rio de Janeiro: Renovar, 2003, p. 117.

506. Op. cit., p. 121. 


\section{CAPÍTULO 4. DANO E INDENIZAÇÃO SOB PARADIGMAS FUNCIONAIS: DO RETROSPECTO INDENIZATÓRIO À PROSPECÇÃO DE DANOS}

\subsection{DANO COMO LESÃO A UM INTERESSE JURÍDICO TUTELÁVEL}

As relações intersubjetivas observadas na sociedade pós-moderna oferecem aos operadores do direito uma multiplicidade de categorias de prejuízos, os quais devem ser selecionados para que, diante da relevância apresentada, receba os efeitos atribuídos pelo ordenamento jurídico. Dano é uma noção perceptível ao senso comum, especialmente aqueles que se originam de fenômenos físicos. Contudo, o mesmo pode constituir-se, ou não, também em um fato jurídico.

Antônio Junqueira de Azevedo ${ }^{507}$ observou que o direito é um subsistema social, ou "sistema de $2^{\mathrm{a}}$ ordem". Assim, juntamente com outros subsistemas sociais, como o econômico, o cultural e o político estão condicionados em função de um sistema maior, o meio social. Através da "autonomia operacional" que lhe é própria, o sistema jurídico movimenta os seus elementos (normas, instituições, operadores do direito, doutrina e jurisprudência) no sentido de atribuir juridicidade aos fatos sociais.

Ocorre que, já ingressando no domínio da responsabilidade civil, nem todo dano terá importância jurídica, o que equivale a dizer, o mesmo somente será causa de efeitos jurídicos quando reunir os elementos constitutivos de um fato jurídico, e assim, atrair a reação que o direito atribui como sanção. ${ }^{508}$ Disso decorre a necessidade do estabelecimento de categorias jurídicas descritivas para que o fato se amolde, e seja disciplinado normativamente.

507. O direito como sistema complexo e de $2^{\mathrm{a}}$ ordem. Estudos e parecedes de direito privado. São Paulo: Saraiva, 2004, p. 26 et seq.

508. DE CUPIS, Adriano. Il danno: teoria generale della responsabilità civile. Vol. I. Milano: Dott. A. Giuffrè Editore, 1966, p.9: "Il processo di qualificazione giuridica dei fatti che il diritto assume nella propria sfera, comprende la determinazione del loro specifico comportamento giuridico: e lo speifico comportamento giuridico del danno, onde esso si differenzia dagli altri fatti giuridici, assumendo una posizione particolare, consiste precisamente nella produzione della detta reazione". 
Restabelecer o equilíbrio social rompido pelo dano tem sido considerado a função primordial da responsabilidade civil ${ }^{509}$. Ocorre que "restabelecer" possui clara conotação retrospectiva. Ora, se a proposta da Responsabilidade Civil Preventiva é o gerenciamento normativo dos riscos para que lesões de repercussões relevantes não se verifiquem, resta indagar qual é o lugar desse pressuposto da responsabilidade civil, dentro da perspectiva preventiva. A evolução da construção deste capítulo tem o propósito de demonstrar qual é o significado de dano dentro deste novo contexto de riscos e complexidades.

O conceito de dano atribuído por diversos autores podem revelar elementos comuns. Para Eduardo A. Zannoni, "el daño se define como el menoscabo que, a consecuencia de un acaecimiento o evento determinado, sufre una persona, ya en sus bienes vitales naturales, ya en su propriedad, ya en su patrimônio". ${ }^{510}$ Por sua vez, para Francesco Carnelutti, “danno è dunque lesione d'interesse". ${ }^{511}$ E para Fernando Noronha,

O dano pode ser caracterizado simplesmente como sendo o prejuízo resultante de uma lesão antijurídica de bem alheio. Numa noção mais esclarecedora, poderá dizer-se que é o prejuízo, econômico ou não-econômico, de natureza individual ou coletiva, resultante de ato ou fato antijurídico que viole qualquer valor inerente à pessoa humana, ou atinja coisa do mundo externo que seja juridicamente tutelada. ${ }^{512}$

As definições expostas são indicativas de que para a caracterização de um dano, não se faz necessária a lesão de um bem determinado, o que reforça o abandono a uma concepção naturalista. Existem interesses não econômicos que igualmente são considerados danos sob o ponto de vista jurídico. É a norma jurídica, neste caso, que vai comandar e atribuir interesse jurídico às diversas situações. É de Clóvis Couto e Silva a distinção entre noção física e noção jurídica do dano, segundo o qual "a norma jurídica seleciona uma fração do fato social para transformá-lo numa situação jurídica. Alude-se a

509. SANSEVERINO, Paulo de Tarso Vieira. Princípio da reparação integral: indenização no Código Civil. São Paulo: Saraiva, 2010, p. 34.

510. ZANNONI, Eduardo A. El daño en la responsabilidad civil. Buenos Aires: Editorial Astrea, 1993, p. 2.

511. CARNELUTTI, Francesco. Il danno e il reato. Padova : CEDAM, 1930, p. 17 : "Ma il diritto non reagisce e non avrrebbe ragione di reagire contro il danno in genere [...] la ragione sorge solo quando la lesione sia una di quelle, le quali, secondo i criteri che dominano 1'ordinamento giuridico, conviene evitare o riparare. "“

512. NORONHA, Fernando. Direito das obrigações. Vol. 1. $2^{\mathrm{a}}$ ed. São Paulo: Saraiva, 2007, p. 555. 
esse propósito a noção de interesse violado". ${ }^{13}$

Portanto, já se caminha em direção a uma delimitação, qual seja: o conceito de dano não é naturalístico, e sim normativo. E nem poderia ser outra a conclusão, considerando que a Constituição Federal de 1988, em seu art. 5º inc. X, resguarda a inviolabilidade de interesses assegurando indenização tanto pelo dano material, como pelo dano moral resultantes de suas violações.

Portanto, o critério predominante, na atualidade, acerca da delimitação do conceito de dano, é que o mesmo configura uma lesão a um interesse, que poderá estar consubstanciado em um direito subjetivo reconhecido pela lei ou uma faculdade aceita pelo ordenamento, ou ainda, tratar de uma vantagem, comodidade ou prazer, de caráter lícito, tendo como titulares pessoas física ou jurídica. ${ }^{514}$

O interesse jurídico é evidenciado: a) pelo poder de atuar que o ordenamento jurídico reconhece ao seu titular, sobre os bens jurídicos (objeto de satisfação); b) uma expectativa, lícita, em assegurar a sua satisfação; c) poder de atuar em defesa de objetos de satisfação que não sejam exclusivos do sujeito, mas da sociedade como um todo (interesses difusos). ${ }^{515}$

A considerar-se que dano é lesão de interesses protegidos normativamente, conclui-se que a sua a noção ontológica é desmaterializada e despatrimonializada, e por isso, podem acarretar consequências de caráter patrimonial ou extrapatrimonial, dependendo da natureza do bem tutelado. ${ }^{516}$ Essa conclusão é particularmente importante, no contexto deste estudo, quando se avalia a dimensão do risco e a possibilidade de seus efeitos se configurarem em momento diverso ao de sua causa.

Pois bem. Se dano é lesão de interesses protegidos normativamente, determinados elementos também devem ser identificados, para a precisão de sua efetiva

513. SILVA, Clóvis Couto e. O conceito de dano no Direito brasileiro e comparado. In: FRADERA, Vera Maria Jacob de (Org.). O Direito Privado brasileiro na visão de Clóvis do Couto e Silva. Porto Alegre: Livraria do Advogado, 1997, p. 219.

514. ITURRASPE, Jorge Mosset; PIEDECASAS, Miguel A. Responsabilidad por daños: actualización doctrinaria y jurisprudencial de los tomos I a X. Tomo XI. Santa Fe: Rubinzal-Culzoni, 2009, p. 116.

515. ZANNONI, Eduardo A. EI daño en la responsabilidad civil. Buenos Aires: Editorial Astrea, 1993, p. 25-26.

516. ALPA, Guido. La responsabilità civile. Parte Generale. Torino: Utet Giuridica, 2010, p. 620. 
ocorrência. São eles: a) certeza; b) a imediatidade; c) injustiça do dano. Paulo de Tarso Sanseverino ${ }^{517}$ orienta acerca do conteúdo a ser observado a partir de cada elemento:

A certeza significa que a lesão ao interesse do prejudicado deve ser real e efetiva sem deixar dúvida acerca da sua existência ou realidade. [...] A imediatidade tem íntima conexão com o nexo causal, pois os prejuízos indenizáveis ou ressarcíveis são aqueles que decorrem direta e imediatament do seu fato gerador. [...] O terceiro elemento é a injustiça do dano $[\ldots]$ o fato gerador da responsabilidade civil fere interesses legítimos da vítima direta ou de terceiros.

Realizadas estas noções introdutórias, cabe ressaltar que justamente com relação à exigência dos referidos elementos é que a configuração dos danos típicos da sociedade de risco apresenta maior perplexidade, e exige uma interpretação renovada.

De recordar-se que na história evolutiva da responsabilidade civil, os reconhecimentos dos danos moral e estético também não estiveram isentos de dificuldades, especialmente quanto à admissão de indenização quando o patrimônio não tenha sofrido qualquer diminuição, além dos embaraços pertinentes à fixação do quantum. Por certo, a consolidação do tratamento jurídico dessa nova categoria de danos ainda tem muito a evoluir, porém, as primeiras ideias já foram lançadas.

Cabe ressaltar que a referência ao dano, prevista no art. 944, do Código Civil, deve ser interpretada de forma includente, compreendendo não apenas os danos individuais, materiais ou imateriais, mas também os danos sociais, difusos, coletivos e individuais homogêneos, ainda que estruturalmente os mesmos mantenham características diferenciadas.

Ao estabelecer um comparativo entre os danos tradicionais objeto da responsabilidade reparatória, e os "novos danos", emergentes da sociedade de riscos, destacam-se as principais distinções. Para a responsabilidade reparatória: a) o dano é atual; b) está vinculado à pessoa ou aos seus bens; c) está amparado na certeza, definição e segurança de sua ocorrência. No âmbito da responsabilidade preventiva: a) o dano é potencial, futuro, transtemporal (derivado do risco intolerável); b) é difuso, com titulares indefinidos ou indetermináveis; c) o dano é incerto e de difícil constatação. 
Os argumentos encontrados tanto pela doutrina, como pela jurisprudência, para lidar com essas realidades - do dano indenizável ao dano evitável, serão expostos a seguir.

\subsection{ANTECIPAÇÃO DA REALIZAÇÃO DO DANO: ENTRE ANTIGOS DOGMAS E O DINAMISMO DA JURISPRUDÊNCIA}

Uma grande dificuldade verificada com relação aos danos típicos dos tempos pós-modernos, é a sua transtemporalidade, podendo atingir gerações atuais e futuras. Além disso, são marcados pela imprevisibilidade, irreversibilidade, irreparabilidade, invisibilidade, consoante já tratado. Disso decorre o emprego dos princípios da precaução e da prevenção, agora institucionalizados na Responsabilidade Civil Preventiva.

Para alcançar esta dimensão, não se faz necessário que a responsabilidade civil crie modalidades específicas de tratamento dos riscos intoleráveis, mas sim atribuir novas interpretações aos pressupostos exigidos.

Uma possibilidade, é a ampliação do conceito de dano, a fim de adequar o risco como um pressuposto da responsabilidade civil. Nesta hipótese, a simples produção do risco já é suficiente para a responsabilização. Se o dano, em sua concepção jurídica, caracteriza-se como lesão a um interesse jurídico tutelável, é possível antever que aquele que não gerencia uma atividade de risco, e em decorrência ocasiona uma ameaça de dano, pode ter sobre si a propositura de uma ação de reponsabilidade civil, o que Teresa Ancona Lopez denomina "responsabilidade civil sem dano". 518

Neste contexto, surgem novas classificações, sendo de particular relevância para este estudo o risco de dano.

De imediato, convém distinguir a referida categoria do dano futuro. Este,

518. LOPEZ, Teresa Ancona. Princípio da Precaução e Evolução da Responsabilidade Civil. São Paulo: Quartier Latin, 2010, p. 133. 
caracteriza-se pela ocorrência certa de consequências futuras de um dano consumado. Por ser uma hipótese em que se pode vislumbrar um perigo concreto, o seu manejo pertence ao domínio do princípio da prevenção, para impedir a ocorrência desse dano, pois baseado em conhecimento sobre a certeza do resultado. Além disso, fará jus à reparação, quando configurada a certeza do prejuízo futuro decorrente do dano presente.

Por sua vez, o risco de dano evidencia-se na plausibilidade do risco gerar danos, porém, não há certeza quanto à sua efetiva ocorrência, embora a gravidade do resultado e a proteção dos bens fundamentais envolvidos exija a aplicação do princípio da precaução para a sua obstrução.

Poderia este risco de dano estar contido na previsão expressa do art. 927, parágrafo único, do Código Civil? Esta resposta merece ser precedida de algumas considerações.

O risco, conforme já foi demonstrado, é uma realidade impossível de se evitar, na sociedade pós-moderna. O que se exige, entretanto, é encontrar formas de gerenciar e conviver com os riscos. Para tanto, a legislação deverá fornecer elementos que permitam a adequação do perfil variável dos mesmos na disciplina de suas normas.

O tratamento jurídico conferido ao risco enfrenta duas possibilidades. A primeira, conforme visto, diz respeito à utilização frente ao mesmo das tutelas inibitória ou de remoção, no intuito de cercear-lhe a possibilidade de causar dano. A segunda, é justamente o alargamento do conceito de dano, para considerar que o risco, em si mesmo, pode ser objeto de indenização. Antes de se estabelecer a análise deste caminho, caberia a indagação acerca dos contornos atribuídos ao risco no conteúdo da cláusula geral de responsabilidade civil objetiva.

O Código Civil, ao consolidar a estrutura legislativa da responsabilidade civil, introduziu uma regra nunca antes verificada no direito pátrio. Valendo-se da técnica legislativa da cláusula geral, introduziu a imputação do dever de indenizar por atribuição meramente objetiva. Diferentemente do estabelecido até então, a responsabilidade não mais se verifica apenas nos casos previstos em lei. E assim, o caráter antes pontual da responsabilidade objetiva torna-se um preceito geral, consoante determinação do art. 927, parágrafo único, do Código Civil: 
Haverá obrigação de reparar o dano, independentemente de culpa, nos casos especificados em lei, ou quando a atividade normalmente desenvolvida pelo autor do dano implicar, por sua natureza, risco para os direitos de outrem.

Essa mudança de postura legislativa provocou grandes reflexões no ambiente doutrinário brasileiro, ávido por encontrar critérios que trouxessem contornos mais precisos ao estabelecido no referido comando legal. Dificuldades dogmáticas foram atribuídas à indeterminação dos termos "atividade normalmente desenvolvida", "sua natureza", e "risco para os direitos de outrem". 519

A análise ora efetuada ficará adstrita à especificação do "risco", bem como a influência que os princípios da precaução e da prevenção podem exercer na sua caracterização. Não é propósito, neste momento, a definição de risco certo ou incerto, o que já foi realizado na Parte II, capítulo 1, deste trabalho. Pois bem.

Caracterizando-se um conceito jurídico indeterminado, é necessário que se estabeleça critérios para a delimitação da noção de risco para a aplicação da responsabilidade objetiva. Para tanto, Cláudio Luiz Bueno de Godoy apresenta uma proposta:

[...] o risco induzido pela atividade do agente, mesmo que não essencialmente perigosa, e menos ainda defeituosa, precisa ser diferenciado, especial, particular, destacado, afinal, se toda e qualquer prática organizada de atos em maior ou menor escala o produz. ${ }^{520}$

Adotando o mesmo entendimento, há o Enunciado 38 da I Jornada de Direito Civil do Centro de Estudos da Justiça Federal, segundo o qual:

[...] a responsabilidade fundada no risco da atividade, como prevista na segunda parte do parágrafo único do art. 927 do novo Código Civil, configura-se quando a atividade normalmente desenvolvida pelo autor do dano causar a pessoa determinada um ônus maior do que aos demais membros da coletividades. ${ }^{521}$

Referidos critérios, porquanto apresentem um caminho para a demarcação

519. CAVAlieri FILHO, Sérgio. Programa de responsabilidade civil. $8^{\text {a }}$ ed. São Paulo: Atlas, 2008, p. 139.

520. Responsabilidade civil pelo risco da atividade. São Paulo: Saraiva, 2009, p.97.

521. Disponível em: <http://www.jf.jus.br/cjf/cej-publ/jornadas-de-direito-civil-enunciados-aprovados/>. Acesso em 01 de junho de 2013. 
do risco, por sua vez, não assinalam qual seria o elemento identificador desse "ônus maior", ou risco "diferenciado, especial e particular", consoante destacado na definição e enunciado acima.

Volvendo às lições do citado professor, há indicação de elementos que auxiliam a verificação dessas especiais exigências, como a constatação estatística dos danos provocados pelo exercício da atividade de risco, a utilização de meios técnicos que possam servir à sua demonstração, e não sendo estes suficientes, a experiência comum. ${ }^{522}$

Em idêntico posicionamento, também foi aprovado o Enunciado 448 da V Jornada de Direito Civil, nos seguintes termos:

Art. 927. A regra do art. 927, parágrafo único, segunda parte, do CC aplica-se sempre que a atividade normalmente desenvolvida, mesmo sem defeito e não essencialmente perigosa, induza, por sua natureza, risco especial e diferenciado aos direitos de outrem. São critérios de avaliação desse risco, entre outros, a estatística, a prova técnica e as máximas de experiência. ${ }^{523}$

É importante destacar, contudo, que os riscos a serem enfrentados podem estar inseridos tanto no campo de atuação do art. 927, parágrafo único, do Código Civil, consoante a interpretação acima assinalada, como também na hipótese de aplicação do princípio da prevenção, e no da precaução, a depender da graduação de incerteza constante na hipótese concreta. Como já visto, o campo de aplicação do primeiro é voltado aos riscos certos, enquanto o da segunda, aos riscos incertos provenientes de incerteza científica.

Assim, de um lado, a aplicação do art. 927, parágrafo único, do Código Civil, é capaz de embasar uma ação reparatória de um dano já ocasionado pelo risco da atividade, risco este que deverá ser diferenciado, e comprovado por estatísticas, regras técnicas ou máximas da experiência. Trata-se do sistema clássico de reparação de danos, retrospectivo, considerando que o risco era certo, condicionado à existência do dano, e não foram observadas as medidas preventivas para que o resultado danoso não se verificasse.

522. GODOY, Cláudio Luiz Bueno de. Responsabilidade civil pelo risco da atividade. São Paulo: Saraiva, 2009, p.99-100.

523. Disponível em: <http://www.jf.jus.br/cjf/cej-publ/jornadas-de-direito-civil-enunciados-aprovados/>. Acesso em 01 de junho de 2013. 
Entretanto, a evolução da tutela jurídica dos riscos permite uma nova racionalidade para a referida cláusula geral. Isto porque, há uma dimensão preventiva na responsabilidade civil, em que os riscos devem ser evitados, cujo reconhecimento ocorre por aplicação de critérios de probabilidade e plausibilidade. Neste sentido:

Vislumbra-se, portanto, a necessidade de superação de uma teoria do risco (concreto), que, paradoxalmente, encontra sua incidência condicionada à ocorrência de um "dano" atual. Essa transição parece-nos possível a partir da formação de uma nova teoria do risco (abstrato), em que as decisões jurídicas tenham como problema a produção de riscos, cujo único elemento passível de avaliação consiste nas probabilidades ou improbabilidades de seu potencial lesivo. Assim, apesar das incertezas a respeito das consequências futuras de determinadas atividades, a norma jurídica não pode se abster de garantir o direito das futuras gerações $[\ldots] .{ }^{524}$

Assim, diante da probabilidade ou plausibilidade de se configurarem danos graves e irreversíveis na sociedade atual, a função preventiva prospectiva da responsabilidade civil merece destaque, exigindo que sejam tomadas medidas prévias, proporcionais e aptas a evitar os riscos de dano. Em outras palavras, essa mudança de paradigma possibilita a "juridicização das condições de risco", 525 em que não há comprovação da concretização do dano, assim como exige a responsabilidade em seu perfil clássico.

Essa interpretação se impõe, sobretudo diante da lúcida observação de Luis Díez-Picazo: "Lo que parece profundamente anacrónico es continuar hablando de riesgo, de creación de riesgo, y de doctrina del riesgo, como si estuviéramos todavía en los años sesenta de ese siglo". 526

Essa é a interpretação contida no Enunciado 446 da V Jornada de Direito Civil, cujo enunciado destaca a prevenção como um critério norteador da noção de risco contida no art. 927 do Código Civil:

524. CARVALHO, Délton Winter de. Dano ambiental futuro: a responsabilização civil pelo risco ambiental. Rio de Janeiro: Forense Universitária, 2008, p. 134.

525. CARVALHO, Délton Winter de. Op. cit., p. 135.

526. DÍEZ-PICAZO, Luis. Fundamentos del derecho civil patrimonial V: la responsabilidade civil extracontratual. Pamplona: Civitas-Thomson Reuters, 2011, p. 130. 
446) Art. 927. A responsabilidade civil prevista na segunda parte do parágrafo único do art.

927 do Código Civil deve levar em consideração não apenas a proteção da vítima e a atividade do ofensor, mas também a prevenção e o interesse da sociedade.

A doutrina ambiental já percebe a possibilidade de vincular o risco incerto ao artigo em comento:

A aceitação de que o risco ambiental é uma questão do direito, observando a possibilidade do fundamento jurídico do parágrafo único do art. 927 do Código Civil, abre espaço para que, no caso concreto, o juiz entenda que o risco intolerável dá fundamento a uma compreensão para a decisão jurídica ${ }^{527}$.

Dentro dessa perspectiva de compreensão funcional da cláusula geral ora analisada, voltada também à prevenção de danos, conclui-se que esta não ocorre por si só, e nem mesmo pelo dano, mas pelo nexo de imputação, o risco.

$\mathrm{Na}$ responsabilidade civil reparatória, diante da exigência do elemento "certeza do dano" para originar uma reparação, enquanto a consequência for futura e incerta, ou seja, enquanto não se realizar o efeito prejudicial em decorrência do risco, o dano é considerado meramente eventual, e portanto, não haveria qualquer responsabilização.

Entretanto, a absorção dos princípios da precaução e da prevenção no sistema de responsabilidade civil é capaz de alterar a concepção tradicional de dano, ao reconhecer, em situações excepcionais, que o risco em si mesmo pode ser reparável. Essa concepção já vem sendo adotada na jurisprudência francesa com relativa facilidade a partir da última década, não se verificando qualquer óbice para que, respeitadas as peculiaridades de cada ordenamento jurídico, no Brasil também seja desenvolvido semelhante entendimento, como um dos mecanismos possíveis para a consolidação da Responsabilidade Civil Preventiva.

As decisões francesas que admitem a responsabilidade pelo risco incerto, normalmente o relacionam a três possibilidades: o risco em si mesmo considerado; a turbação da paz ou dano de ansiedade; as despesas de prevenção. O que se percebe é que a

527. LEITE, José Rubens Morato; AYALA, Patryck de Araújo. Dano ambiental: do individual ao coletivo extrapatrimonial. $4^{\text {a }}$ ed. São Paulo: RT, 2011, p.141. 
jurisprudência, paulatinamente, rompe com a posição ortodoxa da responsabilidade civil, diante de necessidades reais.

Vejamos algumas relevantes ocorrências, a título ilustrativo, que demonstram a possibilidade concreta da Responsabilidade Civil Preventiva ser implementada.

\subsubsection{O RISCO EM SI MESMO CONSIDERADO}

A primeira posição jurisprudencial mencionada no tópico anterior - risco em si mesmo considerado, admite que este pode criar uma ameaça cuja própria existência já é capaz de caracterizar um dano, entendimento que normalmente é vinculado à "théorie des troubles anormaux de voisinage".

Situação sempre lembrada, neste sentido, diz respeito às antenas de retransmissão de telefonia móvel. Embora não haja nenhuma certeza científica de que a exposição é um risco capaz de causar danos à saúde, o medo gerado pelo mesmo justificou a aplicação do Princípio da Precaução, ordenando-se a sua retirada.

Porém, a sua admissibilidade não é pacífica. Philippe Stoffel-Munck ${ }^{528}$, em comentários à decisão do Tribunal de Versailles, que pioneiramente aplicou referido entendimento, tece algumas considerações críticas. Para o jurista francês, não caberia ao magistrado, diante de uma atividade exercida licitamente, e na hipótese de um risco não demonstrável concreta ou abstratamente, desconsiderar a decisão política (autorização pública), sob o argumento do princípio da precaução.

Posicionamentos contrários à parte, o fato é que em outras situações entendimento semelhante foi utilizado. Por exemplo, a Corte de Cassação francesa manteve responsabilidade decorrente da falta de edificação segura de um campo de golfe, que submetia a vizinhança a conviver sob a constante ameaça de projeções de bolas de 
golfe, que embora aleatórias, eram inevitáveis e poderiam causar sérios danos. ${ }^{529}$

Outra demonstração, com a mesma argumentação, foi aplicada ao caso em que determinado imóvel continha armazenamento de palha com altíssimo poder de combustão, o que representava inegável e sério risco ao prédio vizinho. ${ }^{530}$

Diante do requisito certeza do dano, caberia indagar se o risco incerto, por si só, poderia ser considerado um prejuízo reparável, e como visto, já se abrem perspectivas para a sua aceitação.

\subsubsection{TURBAÇÃO DA PAZ E O "PREJUÍZO DE ANSIEDADE"}

Outra relação é possível estabelecer entre a criação de riscos e responsabilidade civil, qual seja, a reparabilidade do dano consistente na ansiedade causada pela exposição ao risco. Trata-se da recente criação jurisprudencial francesa ${ }^{531}$ os “prejuízos de ansiedade” (préjudice d'anxiété).

Nesta hipótese, considera-se que devem ser indenizados os danos sofridos

529. Publication : Bulletin 2004 II N²91 p. 245. Décision attaquée : Cour d'appel de Montpellier, du 5 novembre 2002 Titrages et résumés: PROPRIETE - Droit de propriété - Atteinte - Applications diverses - Troubles anormaux de voisinage - Exonération - Activités agricoles, industrielles, artisanales ou commerciales - Exclusion - Cas. Ne saurait relever de l'exonération de responsabilité tirée de l'article L. 112-16 du Code de la construction et de l'habitation et excède les inconvénients normaux de voisinage l'exposition d'un riverain par suite d'un défaut de conception du tracé d'un parcours de golf, à des tirs de forte puissance contraignant celui-ci à vivre sous la menace constante de projections de balles de golf, certes aléatoires mais néanmoins inéluctables et susceptibles d'avoir de graves conséquences. Disponível em: < http://www.courdecassation.fr/>. Acesso em: 05 nov./2013.

530. Publication : Bulletin 2005 II N 50 p. 46. Décision attaquée : Cour d'appel d’Orléans, du 10 novembre 2003. Titrages et résumés : $1^{\circ}$ PROPRIETE - Droit de propriété - Atteinte - Applications diverses - Troubles anormaux de voisinage - Caractérisation - Cas - Stockage de paille faisant courir un risque indéniable à l'immeuble voisin. $1^{\circ}$ Après avoir relevé que la paille possède un pouvoir de combustion particulièrement rapide et important et qu'une simple étincelle peut suffire à provoquer son inflammation, caractérise l'existence d'un trouble anormal de voisinage, une cour d'appel qui retient que le stockage de paille en limite de propriété et à proximité immédiate d'un immeuble d'habitation faisait courir un risque indéniable à l'immeuble voisin. $2^{\circ}$ PROPRIETE - Droit de propriété - Atteinte Applications diverses - Troubles anormaux de voisinage - Caractérisation - Cas - Dépôt de matériels divers à proximité immédiate du fonds voisin. Disponível em: < http://www.courdecassation.fr/ $>$. Acesso em: 05 nov./2013.

531. Em cinco casos, a Câmara Social da Corte Suprema julgou, em 25 de setembro de 2013, os casos relacionados aos danos de amianto como "prejuízos de ansiedade". 
pelos "prejuízos de ansiedade", que são distúrbios psicológicos gerados pelo risco de danos vinculados às condições existenciais. A Cour de Cassation $^{532}$ francesa utilizou esta fundamentação ao julgar casos referentes a empregados expostos ao risco de manifestação de uma doença relacionada ao amianto. Note-se que, na hipótese, os danos à saúde decorrentes do amianto não haviam ainda se verificado, porém, a angústia, o sofrimento de conviver com a possibilidade de manifestar alguma patologia, o que equivale a dizer - o risco conjugado ao temor, foi considerado passível de indenização.

De certa forma, percebe-se o abandono do requisito certeza do dano (posto que a doença não se manifestou), e admite-se uma variação de dano extrapatrimonial, tão somente fundada no fato da exposição ao agente de risco (no caso, o amianto).

532. Décision attaquée : Cour d'appel d'Agen, du 27 mars 2012 - Titrages et résumés : PRUD'HOMMES - Compétence - Compétence matérielle - Litiges nés à l'occasion du contrat de travail - Sécurité des salariés - Obligation de résultat - Applications diverses - Protection des salariés contre les risques liés à l'inhalation de poussière d'amiante - Manquement - Préjudice spécifique d'anxiété - Indemnisation - Conditions - Période antérieure à la déclaration de la maladie Détermination - La déclaration de la maladie et le contentieux auquel elle a donné lieu ne privent pas le salarié admis au bénéfice de l'allocation de cessation anticipée des travailleurs de l'amiante (ACAATA) du droit de demander à la juridiction prud'homale la réparation des conséquences du trouble psychologique, compris dans le préjudice d'anxiété, subi avant la déclaration de la maladie PRUD'HOMMES - Compétence - Compétence matérielle - Litiges nés à l'occasion du contrat de travail - Sécurité des salariés - Obligation de résultat - Applications diverses - Protection des salariés contre les risques liés à l'inhalation de poussière d'amiante - Manquement - Demande en réparation Conditions - Détermination - Portée - Ayant d'abord constaté que les autres requérants n'avaient pas déclaré souffrir d'une maladie professionnelle causée par l'amiante et que n'étaient contestés ni leur droit à bénéficier de l'ACAATA, ni son montant, la cour d'appel en a exactement déduit que leurs demandes indemnitaires fondées sur le manquement de l'employeur à son obligation de sécurité de résultat relevaient de la compétence de la juridiction prud'homale. La cour d'appel, qui a ensuite relevé que les salariés, qui avaient travaillé dans un des établissements mentionnés à l'article 41 de la loi de 1998 et figurant sur une liste établie par arrêté ministériel pendant une période où y étaient fabriqués ou traités l'amiante ou des matériaux contenant de l'amiante, se trouvaient, par le fait de l'employeur, dans une situation d'inquiétude permanente face au risque de déclaration à tout moment d'une maladie liée à l'amiante, a ainsi caractérisé l'existence d'un préjudice spécifique d'anxiété - TRAVAIL REGLEMENTATION, SANTE ET SECURITE - Employeur - Obligations - Sécurité des salariés Obligation de résultat - Applications diverses - Protection des salariés contre les risques liés à l'inhalation de poussière d'amiante - Manquement - Portée - CONTRAT DE TRAVAIL, EXECUTION - Employeur - Obligations - Sécurité des salariés - Obligation de résultat - Manquement - Préjudice - Préjudice spécifique d'anxiété - Indemnisation - Etendue - Troubles psychologiques - Cas - Troubles liés au bouleversement des conditions d'existence - Droit à une indemnisation distincte (non) - L'indemnisation accordée au titre du préjudice d'anxiété répare l'ensemble des troubles psychologiques, y compris ceux liés au bouleversement dans les conditions d'existence, résultant du risque de déclaration à tout moment d'une maladie liée à l'amiante. Viole dès lors l'article $1147 \mathrm{du}$ code civil et le principe de la réparation intégrale du préjudice, la cour d'appel qui pour faire droit aux demandes d'indemnisation du préjudice résultant du bouleversement dans les conditions d'existence, énonce que les salariés subissent un risque de diminution de leur espérance de vie et de développer une maladie grave les empêchant d'envisager sereinement leur avenir et qu'ils peuvent être amenés à modifier les orientations de leur vie quotidienne et leurs projets de vie en raison de ce risque. Disponível em: < http://www.courdecassation.fr/>. Acesso em: 05 nov./2013. 
O apoio a este posicionamento é dividido entre a doutrina francesa. Patrice Jourdain, ${ }^{533}$ ao refletir sobre o tema, apresenta-se temerário quanto ao abalroamento dos tribunais, a partir do momento em que a simples exposição ao risco é considerada indenizável. Por sua vez, Philippe Brun e Olivier Gout, ${ }^{534}$ defendem que deve ser aprovada a indenização automática do "prejuízo de ansiedade", diante da gravidade dos riscos impostos aos trabalhadores em face da exposição ao amianto.

Doutrinariamente, no Brasil, Teresa Ancona Lopez defende que a ameaça ou risco de danos possa caracterizar dano (prejuízo), e exemplifica:

Pensamos que é possível na teoria e na prática. Ainda nos socorrendo do direito à saúde, podemos lembrar de situações em que pessoas tiveram contato com algum vírus, mas não desenvolveram a doença ou porque ainda não passou o período da chamada "janela imunológica", como no caso da AIDS, e não é possível averiguar se o exame vai dar positivo ou negativo; ou, então, porque há um lapso de tempo muito grande entre o contato e o desenvolvimento da doença, como no caso da temida "hepatite C". Poderá pedir indenização pela ameaça ou risco de desenvolver a doença? O medo constante de ser portador de vírus de doença incurável é, com certeza, dano indenizável. Também poderíamos colocar a hipótese de uma ação civil pública contra ao Município do Rio de Janeiro, em nome de toda a população carioca (não somente dos já contaminados), pelo risco de adquirir dengue por falta de precaução da Prefeitura do Rio de Janeiro. O dano aqui é o risco. ${ }^{535}$

Referidas posições guardam semelhança com a ideia de "turbação da paz", exposta por Carlos A. Calvo Costa:

Al otorgarle nuestra Corte Suprema de Justicia jerarquía constitucional al alterum non laedere, crremos que ello alcanza tambiém a los modos de prevención del Derecho de daños ya que el peligro de daño puede provocar turbación en el goce de intereses ajenos dignos de tutela. ${ }^{536}$

533. Les anciens salariés qui perçoivent l'allocation de préretraite amiante (ACAATA) peuvent-ils solliciter la réparation de leus pertes de revenus? Revue Trimestrielle Droit Civile. Juillet/Septembre. 2010. Paris. Dalloz. 2010, p.564.

534. Responsabilité civile. Recueil Dalloz. Janvier 2011. Paris: Editions Dalloz, 2011, p.35.

535. Responsabilidade civil na sociedade de risco. In: LOPEZ, Teresa Ancona; LEMOS, Patrícia Faga Iglecias; RODRIGUES JÚNIOR, Otavio Luiz. Sociedade de risco e direito privado. São Paulo: Atlas, 2013, p. 10.

536. CALVO COSTA, Carlos A. Daño resarcible. Buenos Aires: Hammurabi, 2005, p. 185. 
No modelo anglo-saxão, apenas para estabelecer um comparativo, já que diante das peculiaridades do sistema brasileiro não se pode transpor a compreensão doutrinária, existem torts considerados per se, ou seja, não exigem a prova do dano, pois a ação que lhes correspondem tem o propósito maior de assegurar o direito do que o de reparar a vítima, como o trespass e o libel..$^{537}$

\subsubsection{DESPESAS DE PREVENÇÃO}

A seu turno, considera-se que a não adoção de medidas tendentes a prevenir o risco pode acarretar responsabilidade, em razão das despesas de prevenção geradas para evitar o dano, passíveis de indenização.

A propósito, os Princípios de Direito Europeu da Responsabilidade Civil, do European Group on Tort Law, trazem previsão a respeito: Art. 2:104. As despesas realizadas com vista a prevenir uma ameaça de dano são consideradas dano ressarcível, desde que a realização dessas despesas se revele razoável. ${ }^{538}$

A veiculação deste entendimento já é adotado jurisprudencialmente. Atentese ao caso em que, o trabalho de escavações em um terreno contíguo gerou uma movimentação de terras que causavam risco ao terreno vizinho. Inicialmente, este julgado é peculiar porque o risco foi caracterizado como "um prejuízo que reúne em si próprio as condições de sua realização". Segundo, o fato de não ter realizado as medidas necessárias para a prevenção do risco $^{539}$ pode ser considerada uma negligência que atribui responsabilidade ao autor do dano pelo custo do trabalho necessário para afastar a situação de risco.

537. FRAZÃO, Ana. Principais distinções e aproximações da responsabilidade civil nos modelos francês, alemão e anglo-saxão. In: RODRIGUES JÚNIOR, Otávio Luiz; MAMEDE, Gladston; ROCHA, Maria Vital da. Responsabilidade civil contemporânea. São Paulo: Atlas, 2011, p. 755.

538. Disponível em: < http://www.egtl.org/>. Acesso em: 23 out./2013.

539. Publication : Bulletin 2008, II, N 112 - Décision attaquée : Cour d'appel de Basse-Terre , du 20 novembre 2006 - Titrages et résumés : RESPONSABILITE DELICTUELLE OU QUASI DELICTUELlE - Dommage - Préjudice certain - Définition - Risque portant en lui-même les conditions de sa réalisation - En application de l'article 1382 du code civil, constitue un préjudice certain, par suite réparable, le risque qui porte en lui-même les conditions de sa réalisation RESPONSABILITE DELICTUELLE OU QUASI DELICTUELLE - Dommage - Réparation Préjudice certain - Définition - Réalisation du préjudice présentant un aléa minime - Absence d'influence. 
A situação referida, ao que parece, amolda-se perfeitamente à categoria de dano futuro, e não risco de dano. Isto porque, no caso concreto, foi avaliado que a escavação no terreno originou um risco com a criação de "massas instáveis" que fatalmente ocasionariam danos em momento ulterior. Patrice Jourdain ${ }^{540}$, em comentários à referida decisão, recorda que "se o prejuízo futuro é reparável, então a sua realização deve ser certa, ou para utilizar uma fórmula habitual, ele deverá constituir o prolongamento certo e direto de um estado de coisas atual". Por sua vez, o dano meramente hipotético não admite indenização, como na hipótese, também referida pelo jurista francês, do caso das sondas cardíacas defeituosas, cuja indenização foi negada a alguns pacientes que desejavam prevenir possíveis riscos futuros.

Da análise das referidas decisões, algumas conclusões podem ser esboçadas. A assunção pela responsabilidade civil de uma função preventiva prospectiva, que traz ao âmbito do referido instituto a necessidade de evitar danos de repercussão indesejada, acarreta como consequência a imposição de que medidas preventivas devem ser asseguradas antes que o dano se efetive. Em uma interpretação dilargada, considera-se que o risco assume o lugar do dano. São posições, evidentemente, que exigem um abandono do método tradicional de atribuição de responsabilidade.

De outro lado, percebe-se que referida proposta, antes confinada ao domínio doutrinário, já começa a encontrar um caminho de amadurecimento e efetiva repercussão na sociedade, através da imposição, pelo Poder Judiciário, de medidas de prevenção ou de reparação quando estiver presente um risco de dano (este ainda não efetivado). Na verdade, referidas situações não tratam, propriamente, de responsabilidade civil sem dano, quando na verdade se percebe que o dano está contido no próprio risco. ${ }^{541}$

540. Responsabilité civile. Revue Trimestrielle de Droit Civile. Octobre/decembre 2008. No 4. Paris. Dalloz. 2008, p. 679.

541. Viney, Geneviève; Jourdain, Patrice. Traité de droit civil: Les conditions de la responsabilité. $3 e$ éd. Paris: L.G.D.J., 2006, p. 6-7. 


\subsection{A INFORMAÇÃO COMO MECANISMO DE PREVENÇÃO DO DANO}

As determinações constitucionais que tratam do direito à informação constituem direitos fundamentais, consubstanciados no art. ${ }^{\circ}, \mathrm{IV}^{542}, \mathrm{XIV}^{543}$ e XXXIII ${ }^{544}$, da Constituição Federal. O direito à informação abrange, portanto, o direito de informar consubstanciado na liberdade de pensamento (inciso IV), o direito de se informar, ou direito de acesso à informação (inciso XIV) e direito de ser informado ou receber informação (inciso XXXIII).

No tocante aos riscos verificados no mercado de consumo, especial relevância adquirem o direito de se informar e o direito de ser informado, que se originam do princípio da transparência, estabelecido no art. $4^{\circ}$, caput, do Código de Defesa do Consumidor como objetivo da Política Nacional das Relações de Consumo. É possível, ainda, ressaltar que o dever de informar também se origina de um dos princípios basilares da Lei $n^{\circ} 8078 / 90$, qual seja, a boa-fé e seu dever anexo de informar, que em última análise se traduz como norma de comportamento indispensável para o equilíbrio da relação de consumo, posto que a vulnerabilidade do consumidor também deva ser considerada na relação estabelecida.

Além disso, constitui direito básico do consumidor, nos termos do art. $6^{\circ}$, inciso III, do Código de Defesa do Consumidor: "a informação adequada e clara sobre os diferentes produtos e serviços, com especificação correta de quantidade, características, composição, qualidade e preço, bem como sobre os riscos que apresentem". Ao direito básico previsto no art. $6^{\circ}$, corresponde o dever do fornecedor, estabelecido no art. 31, em que uma vez mais, a Lei n. 8078/90 ressalta a importância da informação quando trata das práticas comerciais e da oferta na relação de consumo, assegurando que sejam corretas, claras, precisas tanto com referência à oferta e apresentação dos produtos, como sobre os

542. CF/88 - Art. $5^{\circ}$. IV - é livre a manifestação do pensamento, sendo vedado o anonimato.

543. CF/88 - Art. 5 XIV - é assegurado a todos o acesso à informação e resguardado o sigilo da fonte, quando necessário ao exercício profissional

544. $\mathrm{CF} / 88$ - Art. $5^{\circ}$. XXXIII - todos têm direito a receber dos órgãos públicos informações de seu interesse particular, ou de interesse coletivo ou geral, que serão prestadas no prazo da lei, sob pena de responsabilidade, ressalvadas aquelas cujo sigilo seja imprescindível à segurança da sociedade e do Estado 
riscos que apresentam à saúde e à segurança dos consumidores.

Para atender aos ditames do código, a informação recebida pelo consumidor deve preencher os requisitos de adequação, suficiência e veracidade. Cabe notar que há uma relação inversamente proporcional entre a quantidade e a qualidade de informação disponibilizada pelo fornecedor e aquela que o consumidor está disposto a absorver. Neste sentido entende-se que o excesso de informação acaba impossibilitando a compreensão pelo consumidor. ${ }^{545}$

Assim, a informação deverá ser essencial (necessárias e adequadas - art. $8^{\circ}$ ) sobre o uso correto e previsível do produto, ressaltando as advertências (informação ostensiva e adequada - art. $9^{\circ}$ ) sobre os produtos e serviços potencialmente nocivos ou perigosos, seja em função da gravidade, seja em função da frequência de sua ocorrência. As advertências devem realizar-se também com relação ao que não é apropriado ou correto, porém previsível. ${ }^{546}$ Já os produtos que apresentem alto grau de periculosidade ou nocividade sequer poderiam ser colocados no mercado de consumo, porém, permanece um dever pós-contratual de vigilância, e se for constatada violação dos padrões normais de segurança, por imposição dos princípios da precaução e da prevenção, deverão ser informados os consumidores e realizado o recall ${ }^{547}$ administrativo.

Dos dispositivos analisados, denota-se que a informação deve ser proporcional à magnitude do provável risco. Assim, o dever de prevenção realiza-se através do dever de informação. Consoante ressalta Teresa Ancona Lopez, “os princípios da precaução e da prevenção estão consagrados pelo direito do consumidor", ${ }^{548}$ e a

545. Nesse sentido: MARZAGÃO, Nelcina C. de O. Tropardi. Da informação e dos efeitos do excesso de informação no Direito do Consumidor. Tese. Doutorado. Faculade de Direito da Universidade de São Paulo. São Paulo, 2005, p.200.

546. Teresa Ancona LOPEZ expõe um exemplo: “canetas com tinta que pode ser tóxica ou alérgena. É necessário advertir os usuários que isso é possível acontecer se se puser a caneta na boca (o melhor seria eliminar o produto)". Nexo causal e produtos potencialmente nocivos: a experiência brasileira do tabaco. São Paulo: Quartier Latin, 2008, p.91.

547. Brasil - Superior Tribunal de Justiça - REsp 1010392 / RJ - RECURSO ESPECIAL 2006/0232129-5 Relator Ministro Humberto Gomes de Barros - Data do julgamento 24/03/2008 - DJe 13/05/2008 RDDP vol. 66 p. 1202006/0232129-5 CIVIL. CONSUMIDOR. REPARAÇÃO DE DANOS. RESPONSABILIDADE. RECALL. NÃOCOMPARECIMENTO DO COMPRADOR. RESPONSABILIDADE DO FABRICANTE. - A circunstância de o adquirente não levar o veículo para conserto, em atenção a RECALL, não isenta o fabricante da obrigação deindenizar.

548. LOPEZ, Teresa Ancona. Princípio da Precaução e Evolução da Responsabilidade Civil. São Paulo: Quartier Latin, 2010, p. 174. 
informação é um dos mecanismos eficientes para a incidência do efeito preventivo prospectivo da responsabilidade civil, ao contribuir para o alcance da equidade informacional, conforme denominação atribuída pela doutrina alemã (Informationsgerechtigkeit). ${ }^{549}$

Esse dever de informar que deriva da risk communication possui dupla dimensão. Por um lado, o seu escopo óbvio, qual seja, reduzir através da difusão de instruções e advertências acerca dos riscos certos ou incertos, a ocorrência de danos. De outro, preservar a autonomia e a liberdade de decisão dos indivíduos e da sociedade como um todo - que sob o aspecto informacional apresenta ampla vulnerabilidade, ao estreitar a assimetria de informação que os distancia do gestor de riscos, seja o poder público ou os fornecedores no mercado de consumo. Além disso, permite o exercício de uma escolha racional $^{550}$, quer para a construção do sistema regulatório e fiscalização do conteúdo das decisões tomadas, quer para a decisão particular de exposição ou não ao risco. Quanto a este último aspecto, interessante é a observação:

[...] O fato é que todos nós corremos riscos, sempre e voluntariamente: fumantes conhecem bem (hoje, ao menos), os efeitos inegáveis do cigarro; tomar o volante e sair à rua é inserirse no meio que produz maior quantidade de fatalidades que qualquer guerra; o investimento em fundos de renda variável é cada vez mais popular; alpinistas e paraquedistas regozijamse com a sensação de perigo! Na verdade, não temos problema algum em gerenciar riscos, mesmo riscos de vida. O que o indivíduo não aceita é que um risco de dano a ele seja gerenciado por outrem, sem seu devido conhecimento e sua completa compreensão. ${ }^{551}$

Recorde-se que em determinadas situações, o dever de informar adquire

549. MIRAGEM, Bruno. Direito do consumidor. São Paulo: Editora Revista dos Tribunais, 2008, p.122.

550. FLORES FILHO, Edgar Gastón Jacobs; RIBEIRO, Rita de Cássia. Racionalidade Limitada do Consumidor e Assimetria de Informação. Economic A Enalysis of Law Review. V. 3, n ${ }^{\circ}$ 1, p.109121, Jan-Jun, 2012, p.110: “A Teoria da Escolha Racional serve, portanto, como poderoso instrumental para realizar predições a respeito do comportamento humano, bem como para investigar eventuais desvios do comportamento esperado. Desse modo, sabendo que as normas jurídicas são criadas para induzir determinados comportamentos e reprimir outros, conforme sejam valorados, respectivamente, como "bons"' ou "ruins" pelo formulador de políticas públicas, a Teoria da Escolha Racional pode ser utilizada para realizar juízos de prognose e diagnose dessas mesmas normas (Gico Jr., 2010). [...] nem sempre é possível construir um sistema regulatório pressupondo apenas a racionalidade das pessoas. Mesmo pessoas racionais regularmente usam estratégias de simplificação que podem levar a erros (vieses) e nem sempre têm um comportamento reflexivo."

551. HARTMANN, Ivar Alberto Martins. O princípio da precaução e sua aplicação no direito do consumidor: dever de informação. Revista de Direito do Consumidor. Vol. 70. Abril-Junho 2009, p.172. 
caráter ainda mais incisivo, quando exige da outra parte o consentimento informado ${ }^{552}$, o que ocorre sobretudo com relação aos riscos decorrentes de atividades relacionadas à saúde. Neste sentido, o Tribunal Regional Federal da $1^{\text {a }}$ Região já se manifestou no sentido de que o fato de não ter sido observado o consentimento informado a uma paciente acerca dos riscos inerentes a um procedimento que lhe ocasionou a perda da visão, acarreta a responsabilidade objetiva do Estado (um hospital universitário). ${ }^{553}$

No que toca ao direito ambiental, um dos seus princípios formadores é o da informação, previsto na Declaração do Rio de Janeiro, quando garante ao individuo o acesso a "informações relativas ao meio ambiente". Já a Lei 6938/81, que dispõe sobre a Política Nacional do Meio Ambiente, garante à coletividade e obriga ao órgão público ambiental a prestar de informações. Nem mesmo a inexistência da informação reclamada pode ser arguida, pois nesses casos ela deverá ser produzida pelo Poder Público e publicizadas (artigo $9^{\circ}$, inciso XI). É condição constitucional para a garantia do direito fundamental ao ambiente ecologicamente equilibrado, das presentes e futuras gerações, a publicidade dada pelo órgão ambiental (municipal, estadual ou federal) aos dados relativos à determinada obra e ou atividade, atinente ao licenciamento ambiental ou ao Estudo Prévio de Impacto Ambiental e seu respectivo Relatório de Impacto ao Meio Ambiente.

Ademais, a aplicação do princípio da precaução é fortalecida pela prática da informação e participação pública nos processos de tomada de decisão. A adoção de

552. Conforme Christoph FABIAN: "O médico deve esclarecer sobre a forma da intervenção e sobre aqueles riscos da intervenção, que não ficarem completamente fora da probabilidade. [...] O médico deve informar sobre os riscos possíveis do tratamento, salvo aqueles que acontecem raramente. Para a probabilidade do risco não importa alguma estatística, é preciso informar sobre aqueles riscos raros que podem se realizar especificamente no tratamento." O dever de informar no direito civil. São Paulo: Editora Revista dos Tribunais, 2002, p.136.

553. TRF-1 - AC: 15462 MG 2002.38.00.015462-1, Relator: DESEMBARGADOR FEDERAL JIRAIR ARAM MEGUERIAN, Data de Julgamento: 04/03/2013, SEXTA TURMA, Data de Publicação: eDJF1 p.213 de 18/03/2013 - Ementa: PROCESSO CIVIL E ADMINISTRATIVO. INDENIZAÇÃO POR ERRO MÉDICO. FALTA DE COMPROVAÇÃO. FALTA DE CONSENTIMENTO INFORMADO. SENTENÇA MANTIDA. I - De acordo com o disposto no art. 37 , $\S 6^{\circ}$, da CF, o Estado responde objetivamente pelos danos que seus agentes, nessa qualidade, causarem. II - Em que pese o fato de a autora ter desistido da produção da prova pericial, a prova testemunhal e os demais documentos carreados aos autos demonstram que houve a necessidade de realização de uma segunda cirurgia decorrente de complicações advindas da primeira realizada. III - O Estado não se desincumbiu do ônus de demonstrar que a perda da visão decorreu de particularidades da paciente e que ela foi previamente cientificada acerca dos riscos inerentes ao procedimento. Falta de consentimento informado. Nexo causal demonstrado. IV - Recurso da UFMG e remessa oficial tida por interposta a que se nega provimento. Sentença mantida. 
medidas de precaução que visem a evitar problemas ambientais estimula uma postura de cautela na sociedade no caso de não haver certeza científica sobre os riscos gerados por determinada atividade. Quanto à participação democrática nos processos decisórios, para que seja efetiva, há que se garantir, inicialmente, o respeito ao direito à informação precisa e transparente, sobre as questões que serão submetidas à análise da sociedade, para que esta possa discutir o projeto com base nessas informações.

\subsubsection{SEGURANÇA ALIMENTAR E UM CASO PARADIGMÁTICO: DOENÇA CELÍACA E DEFEITO DE INFORMAÇÃO NA JURISPRUDÊNCIA DO STJ}

O direito à alimentação foi incluído recentemente em nosso país no rol dos direitos sociais individuais e coletivos da Constituição Federal de 1988, através da Emenda Constitucional $n^{\circ} 64 / 2010$, conferindo nova redação ao seu artigo $6^{\circ}$, nos seguintes termos:

Art. $6^{\circ}$. São direitos sociais a educação, a saúde, a alimentação, o trabalho, a moradia, o lazer, a segurança, a previdência social, a proteção à maternidade e à infância, a assistência aos desamparados, na forma desta Constituição.

Referida inclusão não reflete exatamente uma inovação no ordenamento jurídico, posto que o direito humano à alimentação já estivesse previsto na Declaração Universal dos Direitos Humanos, de 1948:

Artigo XXV - 1. Toda pessoa tem direito a um padrão de vida capaz de assegurar a si e a sua família saúde e bem-estar, inclusive alimentação, vestuário, habitação, cuidados médicos e os serviços sociais indispensáveis, o direito à segurança, em caso de desemprego, doença, invalidez, viuvez, velhice ou outros casos de perda dos meios de subsistência em circunstâncias fora de seu controle.

Por sua vez, o Pacto Internacional dos Direitos Econômicos, Sociais e Culturais, de 1966, em seu artigo 11, além de incluir a previsão do direito à alimentação, também propõe mecanismos para a operacionalização desse direito:

1. Os Estados Partes do presente Pacto reconhecem o direito de toda pessoa a nível de vida adequado para si próprio e sua família, inclusive à alimentação, vestimenta e moradia adequadas, assim como a uma melhoria contínua de suas condições de vida. Os Estados 
Partes tomarão medidas apropriadas para assegurar a consecução desse direito, reconhecendo, nesse sentido, a importância essencial da cooperação internacional fundada no livre consentimento.

2. Os Estados Partes do presente pacto, reconhecendo o direito fundamental de toda pessoa de estar protegida contra a fome, adotarão, individualmente e mediante cooperação internacional, as medidas, inclusive programas concretos, que se façam necessárias para: a) melhorar os métodos de produção, conservação e distribuição de gêneros alimentícios pela plena utilização dos conhecimentos técnicos e científicos, pela difusão de princípios de educação nutricional e pelo aperfeiçoamento ou reforma dos regimes agrários, de maneira que se assegurem a exploração e a utilização mais eficazes dos recursos naturais; b) Assegurar uma repartição equitativa dos recursos alimentícios mundiais em relação às necessidades, levando-se em conta os problemas tanto dos países importadores quanto dos exportadores de gêneros alimentícios. (grifos da autora)

A definição do direito à alimentação, bem como à nutrição adequada é explicitada no Comentário Geral n ${ }^{\circ}$ 12, adotado em 1999 pelo Comitê de Direitos Econômicos, Sociais e Culturais, órgão responsável pela implementação do Pacto Internacional dos Direitos Econômicos, Sociais e Culturais, norma acima descrita, nos seguintes termos:

O direito à alimentação é o direito de ter um acesso regular, permanente e livre tanto diretamente ou por meio de compras financiadas, à alimentação suficiente e adequada tanto quantitativamente como qualitativamente, correspondendo às tradições culturais das pessoas a quem o consumo pertence, e que assegura uma realização física e mental, individual e coletiva, de uma vida digna e livre de medo. [...]O direito à alimentação adequada realiza-se quando cada homem, mulher e criança, sozinho ou em companhia de outros, tem acesso físico e econômico, ininterruptamente, à alimentação adequada ou aos meios para sua obtenção. O direito à alimentação adequada não deverá, portanto, ser interpretado em um sentido estrito ou restritivo, que o equaciona em termos de um pacote mínimo de calorias, proteínas e outros nutrientes específicos. O direito à alimentação adequada terá de ser resolvido de maneira progressiva. No entanto, os estados têm a obrigação precípua de implementar as ações necessárias para mitigar e aliviar a fome, como estipulado no parágrafo 2 do artigo 11, mesmo em épocas de desastres, naturais ou não.

Dos enunciados acima, retira-se que o conceito de direito à alimentação 554 incorpora aspectos relacionados à: a) acessibilidade, compreendida no sentido de garantir o

554. O direito à alimentação aqui referido deve ser tratado em sentido lato, incluindo tanto o direito ao alimento sólido, como também o direito substancial à água potável e à nutrição líquida. 
acesso físico e econômico permanente dos povos para a sua aquisição e também no sentido de garantir a suficiência e disponibilidade de gêneros alimentícios diversificados; b) adequação, englobando tanto o conteúdo nutricional da dieta e o respeito ao seu aspecto cultural nas diversas regiões, como também a proteção contra a contaminação e a necessidade de estar livre de substâncias nocivas; c) sustentabilidade, o que implica que a alimentação diversificada e segura seja acessível tanto na atualidade como para as gerações futuras.

Da junção dos três aspectos destacados acima, é possível evidenciar que o direito à alimentação ultrapassa a simples disponibilidade de alimentos, para alcançar uma dimensão que requer o respeito ao estado de saúde das pessoas. Há, portanto, uma estreita relação e indivisibilidade entre o direito à alimentação adequada e o direito à saúde, bem como à própria dignidade humana em suas dimensões natural e ecológica ${ }^{555}$, e a proteção ao meio ambiente. A segurança alimentar, neste passo, apresenta-se como consequência inexorável do direito à alimentação.

A implementação da segurança alimentar ocorre por meio do dever de informar. Com relação à proteção contra riscos, a obrigação de informar deriva da obrigação de segurança, que modernamente é exigida para o exercício de qualquer atividade profissional ou colocação de produto no mercado de consumo. Não se veja, contudo, nessa manifestação, uma simples garantia contra vícios redibitórios, tal qual prevista no Código Civil. A rigor, o dever de informar assume, nos dias atuais, verdadeira natureza autônoma.

Especialmente com relação à segurança, o dever de informar se desdobra

555. Ingo Wolfgang Sarlet e Tiago Fensterseifer esclarecem: "não nos parece possível excluir de uma compreensão necessariamente multidimensional e não reducionista da dignidade da pessoa humana, aquilo que se poderá designar de uma dimensão ecológica (ou quem sabe, formulado de um modo integrativo, socioambiental) da dignidade humana, que, por sua vez, também não poderá ser restringida a uma dimensão puramente biológica ou física, pois contempla a qualidade de vida como um todo, inclusive do ambiente em que a vida humana (mas também a não humana) se desenvolve. É importante, aliás, conferir um destaque especial para as interações entre a dimensão natural ou biológica da dignidade humana e a sua dimensão ecológica, sendo que esta última objetiva ampliar o conteúdo da dignidade da pessoa humana no sentido de assegurar um padrão de qualidade e segurança ambiental mais amplo (e não apenas no sentido da garantia da existência ou sobrevivência biológica), mesmo que muitas vezes esteja em causa em questões ecológicas a própria existência natural da espécie humana, para além mesmo da garantia de um nível de vida com qualidade ambiental". Direito constitucional ambiental: estudos sobre a constituição, os direitos fundamentais e a proteção do ambiente. São Paulo: Editora Revista dos Tribunais, 2011, p. 60. 
em intensidades diversas. Com efeito, o art. 31 do Código de Defesa do Consumidor é desdobra o dever de informar em quatro categorias principais, imbricadas entre si, em diálogo e sobreposição: a) informação-conteúdo, que diz respeito às características intrínsecas do produto e serviço, b) informação-utilização, impondo esclarecimento para o que se presta e se utiliza o produto ou serviço, c) informação-preço, ou seja, o custo, formas e condições de pagamento do produto ou serviço; d) informação-advertência, sobretudo quanto aos riscos do produto ou serviço.

Referida classificação adquire especial relevância quando o que se tem em análise é a segurança que decorre do dever de informação com relação à segurança alimentar.

Situação que bem ilustra essa dimensão foi objeto de decisão do Superior Tribunal de Justiça ${ }^{556}$, ocasião em que Antônio Herman V. Benjamin, na qualidade de relator, analisou o descumprimento do dever de advertir sobre os riscos que o glúten, presente na composição de certos alimentos industrializados, apresenta à saúde e à segurança de uma categoria de consumidores - os portadores de doença celíaca.

Extrai-se do trecho do referido acórdão a significativa distinção entre informação-conteúdo e informação-advertência, especialmente na prevenção de acidentes de consumo:

Dessa classificação decorre que, embora toda advertência seja informação, nem toda informação é advertência. Quem informa nem sempre adverte. A advertência é informação qualificada: vem destacada do conjunto da mensagem, de modo a chamar a atenção do

556. Brasil - Superior Tribunal de Justiça - RECURSO ESPECIAL No 586.316 - MG (2003/0161208-5) RELATOR : MINISTRO HERMAN BENJAMIN - EMENTA: DIREITO DO CONSUMIDOR. ADMINISTRATIVO. NORMAS DE PROTEÇÃO E DEFESA DO CONSUMIDOR. ORDEM PÚBLICA E INTERESSE SOCIAL. PRINCÍPIO DA VULNERABILIDADE DO CONSUMIDOR. PRINCÍPIO DA TRANSPARÊNCIA. PRINCÍPIO DA BOA-FÉ OBJETIVA. PRINCÍPIO DA CONFIANÇA. OBRIGAÇÃO DE SEGURANÇA. DIREITO À INFORMAÇÃO. DEVER POSITIVO DO FORNECEDOR DE INFORMAR, ADEQUADA E CLARAMENTE, SOBRE RISCOS DE PRODUTOS E SERVIÇOS. DISTINÇÃO ENTRE INFORMAÇÃO-CONTEÚDO E INFORMAÇÃOADVERTÊNCIA. ROTULAGEM. PROTEÇÃO DE CONSUMIDORES HIPERVULNERÁVEIS. CAMPO DE APLICAÇÃO DA LEI DO GLÚTEN (LEI 8.543/92 AB-ROGADA PELA LEI 10.674/2003) E EVENTUAL ANTINOMIA COM O ART. 31 DO CÓDIGO DE DEFESA DO CONSUMIDOR. MANDADO DE SEGURANÇA PREVENTIVO. JUSTO RECEIO DA IMPETRANTE DE OFENSA À SUA LIVRE INICIATIVA E À COMERCIALIZAÇÃO DE SEUS PRODUTOS. SANÇÕES ADMINISTRATIVAS POR DEIXAR DE ADVERTIR SOBRE OS RISCOS DO GLÚTEN AOS DOENTES CELÍACOS. INEXISTÊNCIA DE DIREITO LÍQUIDO E CERTO. DENEGAÇÃO DA SEGURANÇA. 
consumidor, seja porque o objeto da advertência é fonte de onerosidade além da normal, seja porque é imprescindível à prevenção de acidentes de consumo.

Com relação ao fato julgado, considerou-se que a simples informação "Contém glúten" não possui o alcance necessário para que a informação seja efetivamente compreendida por grande parte dos consumidores. Trata-se, na espécie, de mera informação-conteúdo, quando na verdade a gravidade do risco exigiria o atendimento à informação-advertência, sem qualquer operatividade.

Além disso, é preciso considerar que há o consumidor genérico vulnerável, e ainda, aqueles hipervulneráveis, para os quais o dever de informar deve ser ainda mais efetivo. Nestes casos, os fornecedores do produto devem guardar uma cautela ainda maior, considerando as particularidades de saúde e segurança de cada grupo em especial. Para tanto, a rotulagem adquire importância primordial, que não deve ser genérico, mas sim específico e incisivo com relação aos riscos que o produto apresenta para determinadas pessoas, o que tem especial relevo nos alimentos, e também nos medicamentos.

Portanto, a interpretação a ser empregada ao art. 31 do Código de Defesa do Consumidor ampara não só a generalidade de consumidores, mas também grupos e categorias de consumidores que, por uma razão ou outra, necessitam de uma tutela mais efetiva, através do dever de informar que adquire a nota de advertência, considerando determinados alimentos cujo risco à saúde é de particular relevância.

\subsubsection{DEVER DE INFORMAR E CONTROVÉRSIAS ACERCA DA ROTULAGEM DE OGM}

Cabe, neste ponto, estabelecer a relação entre dever de informar e rotulagem, tendo como paradigma as controvérsias estabelecidas com relação aos alimentos derivados de organismos geneticamente modificados.

Ângela Frota define rotulagem como "o conjunto de todas as menções, indicações, marcas de fabrico ou de comércio, imagens ou símbolos referentes a um gênero alimentício e que figurem em qualquer embalagem, documento, aviso, rótulo, anel ou 
gargantilha que acompanhe, ou seja, referente a tal gênero alimentício". 557

No mercado de consumo, se for observado que se os riscos de um produto ou serviço são alarmantes, a opção dos respectivos órgãos reguladores é controlar minuciosamente a sua circulação, como é o caso dos os medicamentos e agrotóxicos, fiscalizados pela ANVISA.

Já para outros produtos cujos riscos são mais restritos, a solução apresentada pelo legislador e pelo administrador é, de um lado, flexibilizar o controle de comercialização, e de outro exigir maior rigor nas informações prestadas, sobretudo na rotulagem. Por essa razão, especialmente com relação à segurança alimentar, especial importância é conferido à rotulagem do alimento.

A Lei de Biossegurança (Lei n. 11.105/05), que em seu art. 40, determina que os alimentos e ingredientes alimentares destinados ao consumo humano ou animal que contenham ou seja produzidos a partir de OGM ou derivados deverão conter informação nesse sentido em seus rótulos, conforme regulamento.

Perceptível, nesse viés, que há um dever concreto e positivo de informação (risk communication). E tal informação deverá ser instrumentalizada na rotulagem do produto, nos termos da regulamentação específica. Assim, o Decreto 4680/03, em seu art. $2^{\circ}$, determina que os alimentos e ingredientes alimentares destinados ao consumo humano ou animal que contenham um limite superior a um por cento de OGM na sua composição devem possuir rótulo contendo informações sobre tal característica, o que caracteriza a rotulagem negativa. A seu turno, estabelecendo a possibilidade de uma rotulagem positiva, o art. $3^{\circ}$ do mesmo decreto estabelece que os alimentos e ingredientes alimentares que não contenham nem sejam produzidos a partir de organismos geneticamente modificados será facultada a rotulagem "(nome do produto ou ingrediente) livre de transgênicos", desde que tenham similares transgênicos no mercado brasileiro.

Assim, a rotulagem pode ser considerada um mecanismo de efetivação do direito de informação do consumidor, permitindo a este o conhecimento e direito de escolha sobre o que está consumindo.

557. O regime da segurança alimentar na União Européia. Curitiba: Juruá, 2007, p.78. 
A grande polêmica sobre a questão surge a partir da indagação se as normas do Decreto 4680/03 ferem o CDC e os direitos do consumidor, na medida em que o direito à informação, garantido pelo Código (especialmente os artigos $6^{\circ}$, III e 31) garante o direito à informação plena, independentemente do limite de tolerância estabelecido pelo decreto, qual seja, superior a um por cento de OGM.

A doutrina se divide entre argumentos a favor do direito pleno à informação, e aqueles que defendem a previsão de um percentual de tolerância, tal qual estabelecido no Decreto 4680/2003.

Cláudia Lima Marques, defensora da primeira corrente, de maneira incisiva destaca que:

o direito à informação dos consumidores não deve encontrar nenhum limite a não ser a determinação científica da presença do OGM, nem de $1 \%$, pois viola fortemente o direito à informação que é total e deve ser definido pela ciência e sua capacidade de detectar o OGM no alimento. Há muitos colorantes e ingredientes que têm uma porcentagem inferior e que são mencionados no rótulo. Se realmente os transgênicos não causam danos à saúde pública, então não há nenhuma razão de não informar os consumidores. A informação sobre os transgênicos é uma informação necessária à saúde e à dignidade humana. A lei brasileira deve ser aperfeiçoada e o governo deve começar um controle eficaz, com pesadas sanções administrativas (e mesmo penais) em caso de violação das regras. ${ }^{558}$

Nesta ótica, em que se quer assegurar o exercício pleno do direito de escolha pelo consumidor, o importante não é o estabelecimento do quantum do OGM, mas sim o conhecimento de sua presença. A partir da compreensão de que o ingrediente do produto é informação inerente à sua característica, o mesmo não poderia ser omitido. De observar-se, ainda, que a própria Lei de Biossegurança, que é posterior ao Decreto 4680/03, não faz limitação de percentual para a rotulagem.

De outro lado, os argumentos que defendem a previsão de um percentual de tolerância dos OGM em alimentos podem ser sintetizados: a) não se pode argumentar que os OGM oferecem riscos à saúde, porque uma vez liberados para comércio pela CTNBio, pressupõe a sua segurança; b) os arts. $6^{\circ}$ e 31 do CDC tem conteúdo genérico para oferta

558. Organismos geneticamente modificados, informação e risco da "novel food": o direito do consumidor desarticulado? Cadernos doPrograma de Pós-Graduação em Direito. Vol. III, $n^{\circ}$ VI. Porto Alegre: PPGDir./URFGS, 2005, p. 23. 
de qualquer produto ou serviço, e tratando-se produtos alimentícios, as normas gerais do CDC devem ser complementadas por outras de ordem técnica específicas para este tipo de produto, no caso, o Decreto $4.680 / 03$; c) o percentual limitador justifica-se porque não existem alimentos absolutamente puros, sendo que não há como fornecer garantias de qualquer nível de pureza no processo de produção; d) o próprio Codex Alimentarius da FAO/OMS estabelece níveis toleráveis de resíduos em alimentos humanos, e os rótulos não informam a presença desses fragmentos, porque os considera toleráveis; f) alto custo da rotulagem, sendo que mais justo e economicamente racional seria rotular com o adjetivo "livre de...", pois assim somente os consumidores interessados pela informação arcariam com os custos decorrentes.

Outra questão tormentosa, com relação ao art. $8^{\circ}$ do Decreto 4680/03, é a determinação de que a informação acerca da presença do OGM acima de um por cento na rotulagem seja acompanhada de um "símbolo a ser definido mediante ato do Ministério da Justiça”. A definição desse símbolo foi estabelecida através da Portaria 2658/03. Trata-se da letra "T" inserida dentro de um triângulo de cor amarela. Ocorre que, nos termos da Norma ISO 3864-2002, este símbolo seria indicativo de "perigo". Sendo assim, considerando que a liberação para comércio de organismos geneticamente modificados deve ser submetida à rigorosa avaliação de segurança alimentar e no meio ambiente, o indicativo de "perigo" configura-se inadequado. Ademais, a presença do símbolo poderia causar dúvidas ao consumidor, afastando-o do consumo do produto, com efeitos nocivos à comercialização. 


\section{CAPÍTULO 5. NEXO DE CAUSALIDADE: ENTRE RISCO, (IN)CERTEZA E PROBABILIDADE}

\subsection{DA CAUSALIDADE MATERIAL À CAUSALIDADE JURÍDICA: RESPONSABILIDADE PRESUMIDA}

O nexo de causalidade é um dos pressupostos da responsabilidade civil, que vincula o dano diretamente ao ato, e indiretamente ao elemento de imputação subjetiva ou de atribuição objetiva. ${ }^{559}$

A influência dos princípios da precaução e da prevenção, aliada à problemática dos riscos na sociedade pós-moderna, impõe o surgimento de uma nova alternativa para a apuração jurídica do nexo - a presunção de causalidade. Esta atua como um fator de expansão daquele, pois "repousa suas bases não mais em uma relação direta entre dano e agente, mas também na relação entre dano e a potencialidade do agente evitá1o". ${ }^{560}$ Por outras palavras, "a causalidade tem de deixar de ser vista como uma categoria do mundo físico, mesmo que normativizada, para ser entendida em termos de imputação". 561

Assim, a probabilidade do dano não requer um nexo causal certo e determinado, mas um liame provável. A compreensão dessa perspectiva somente é possível se o discernimento entre causalidade material e causalidade jurídica estiver presente.

A previsão do Código Civil que enfrenta o problema da causalidade é localizada no âmbito do inadimplemento das obrigações - o art. 403, segundo o qual: "ainda que a inexecução resulte de dolo do devedor, as perdas e danos só incluem os prejuízos efetivos e os lucros cessantes por efeito dela direto e imediato, sem prejuízo do disposto na lei processual”.

559. ALSINA, Jorge Bustamante. Teoría general de la responsabilidad civil. Buenos Aires: AbeledoPerrot, 1997, p. 101.

560. LEMOS, Patrícia Iglecias Faga. Resíduos sólidos e responsabilidade civil pós-consumo. São Paulo: RT, 2011, p. 147.

561. BARBOSA, Ana Mafalda Castanheira Neves de Miranda. Responsabilidade civil extracontratual: novas perspectivas em matéria de nexo de causalidade. Cascais: Princípia, 2014, p. 285. 
O âmbito de aplicação do referido dispositivo e a interpretação da locução "efeito dela direto e imediato" constituem dois aspectos fundamentais acerca do tema. Em particular, indaga-se se a verificação do nexo de causalidade entre a conduta e o evento lesivo é material, ou se permite a seleção jurídica de consequência danosa indenizável.

Dentro dessa verificação, identifica-se que o nexo de causalidade na responsabilidade civil não é um conceito unitário, pois assume relevância a partir de duas perspectivas: de uma parte o evento lesivo (dano-evento), de outra parte o dano indenizável (dano-prejuízo). ${ }^{562}$

Com relação ao primeiro (dano-evento), referido pressuposto desenvolve a função de imputar ao responsável o fato danoso, e nesse caso é possível identificar a causalidade de fato, ou natural, ou material. Já no que toca ao dano-prejuízo, a identificação do nexo busca determinar o montante do dano indenizável, e neste caso prepondera a noção de causalidade jurídica.

A partir dessa visão dicotômica, o liame causal cumpre dois objetivos: a) determinar a quem se deve atribuir o efeito danoso; b) determinar a extensão do dano a ser indenizado.

Em consequência, a causalidade material e a causalidade jurídica apresentam características bastante diversas. A causalidade material é um procedimento que leva a sustentar que "uma ação individual é causa de outra ação individual, e que outra, não é". ${ }^{563}$ Por sua vez, a causalidade jurídica permite a individualização da singular consequência danosa, com a precípua função de delimitar os limites da indenização. Por outras palavras, a causalidade fática é a causalidade do mundo fenomênico e a causalidade jurídica é a porção da primeira que assume relevância para o direito. ${ }^{564}$

No âmbito da Responsabilidade Civil Preventiva, a causalidade jurídica, conforme sustenta Daphné Tapinos, ${ }^{565}$ demanda um esforço intelectual que permite atribuir

562. FLUMIGNAN, Silvano José Gomes. Dano-evento e dano-prejuízo. Dissertação. Faculdade de Direito da Universidade de São Paulo. 2009.

563. ACCIARRI, Hugo. A. La relación de causalidad y las funciones del Derecho de Daños: reparación, prevención, minimización de costos sociales. Buenos Aires: AbeledoPerrot, 2009, p. 9.

564. ACCIARRI, Hugo. Op. cit., p. 11.

565. Prévention, précaution et responsabilité civile. Paris: L'Harmattan, 2008, p. 85. 
o fato ao seu autor, sendo esta espécie típica de uma responsabilidade por falha na prevenção ou falha na precaução. O liame de causalidade jurídica se apresenta, nestas duas hipóteses, na relação entre uma abstenção e a realização de um risco.

Assim, ao se realizar uma leitura sistemática, emerge um plexo operativo racional, articulado segundo um critério de consequencialidade em virtude do qual o intérprete opera uma distinção entre o momento estrutural da identificação da responsabilidade (certeza do dano), e o instante funcional acerca do conteúdo da mesma (a quantificação).

Outra consideração é relevante para o tema deste trabalho, qual seja, a causalidade científica. Esta paira, inevitavelmente, diante de eventuais lacunas probatórias, antes que a certeza acerca do objeto de estudo seja estabelecida, e é sustentada em suposições ou avaliações inspiradas pela probabilidade. Já a causalidade jurídica, opera mediante uma série de ferramentas próprias, hábeis a gerenciar o perfil probatório no âmbito da reconstrução da sequência causal ${ }^{566}$ (flexibilização do nexo, inversão do ônus da prova, teorias justificadoras de presunção causal).

Portanto, a o nexo causal jurídico persegue uma racionalidade prática, que permite aos operadores do direito o escopo de identificar, no conjunto de causas que determinam um fenômeno, aquelas que apresentam relevância jurídica. Por essa razão, o mesmo acontecimento pode desencadear uma diversidade de consequências para o Direito, e este pode atribuir efeitos a uma ação que, na realidade fática, não possui uma causa antecedente. $^{567}$

Interessante observar que nem sempre haverá necessidade do nexo causal para o dever de indenizar. Para ilustrar, temos a responsabilidade civil agravada, no qual ao responsável é imputado o dever de reparar o dano não causado pelo mesmo, ${ }^{568}$ como o dano nuclear (art. $4^{\circ}$, Lei $n^{\circ}$ 6453/77). Também há responsabilidade com ausência de nexo causal nos casos de seguros de responsabilidade civil e fundos coletivos de reparação de

566. VACCARO, Roberta. Nesso di causalità e prova statistica. Tesi di dottorato. Facoltà di Giurisprudenza. Università degli Studi "ROMA TRE".

567. Costa Júnior, Paulo José da. Nexo causal. 4. ed. rev. e atual. São Paulo: Revista dos Tribunais, 2007, p. 108.

568. NORONHA, Fernando. Direito das obrigações. Vol. 1. 2a ed. São Paulo: Saraiva, 2007, p. 611. 
vítimas.

Considerando o nexo causal jurídico, a necessidade de sua flexibilização, de acordo com Patrícia Iglecias Faga Lemos, ${ }^{569}$ reside tanto em suplantar a dificuldade da prova do dano pela vítima (pluralidade de causas, caráter invisível dos prejuízos, incerteza relativa aos efeitos de uma determinada emissão, lapso temporal entre o fato gerador do dano e seus efeitos); como a superar a impossibilidade de traçar um liame lógico diante de danos difusos.

Diante disso, as técnicas de presunção constituem uma alternativa para aperfeiçoar e atribuir maior efetividade à aplicação da responsabilidade civil, especialmente nos casos em que a sua prova se mostra difícil pela via tradicional. A respeito da adoção da presunção, Luis Filipe Pires de Sousa dispõe que

A presunção é um recurso cognitivo da comunicação, ciência e do direito que assume especial acutilância no direito civil, onde desempenha um papel fulcral na prova designadamente de factos psíquicos, volitivos e cognitivos. Ao contrário da doutrina clássica que subalternizava a eficácia da presunção, esta pode sustentar por si só o convencimento judicial, salvo nos limitados casos em que a lei impede a sua utilização.Salvaguardadas estas situações, a presunção não é hierarquicamente inferior aos meios de prova comuns. ${ }^{570}$

Cumpre, neste ponto, estabelecer o sentido de presunção. Teresa Ancona Lopez, ao destacar o papel das presunções dentro da técnica do direito, anota que:

Em primeiro lugar, é através de presunções que o legislador chega a determinados conceitos legais, ou melhor, ao conteúdo das normas jurídicas, conteúdo este estabelecido conforme o que habitualmente acontece, isto é, de acordo com os fatos, por final, fatos dos mais variados tipos. Além disso, ao elaborar um sistema normativo, presume também o legislador os valores imperantes em determinada sociedade e, assim, adapta, da melhor maneira possível, a norma à realidade social. É evidente que, ao colocar as normas, torna verdadeiros fatos que podem ser apenas prováveis. [...] A presunção, por outro lado, é também um elemento importante na dialética da prova jurídica. Aqui não se trata somente das presunções elaboradas pelos magistrados para auxiliá-los na formação de sua convicção durante o julgamento, e admitidas em todos os casos em que é a prova testemunhal. Trata-

569. Op. cit., p. 150-151.

570. Prova por presunção no direito civil. Coimbra: Almedina, 2012, p. 11. 
se, principalmente, das presunções legais, isto é, as presunções ligadas ao conceito de "onus probandi” e que são de fundamental importância na teoria geral do Direito. ${ }^{571}$

As presunções de fatos são previstas no Código Civil Brasileiro, art. 212, inciso IV, bem como no Código de Processo Civil, em seu art. 335. Já as presunções legais são tratadas no Código de Processo Civil, em seu art. 334, inciso IV.

São as presunções fáticas que constituem meios de prova, pois buscam a experiência comum para chegar a um resultado. As presunções legais absolutas destinamse à criação de regras jurídicas, já as presunções legais relativas dispensam provas daqueles a quem beneficiam, mediante inversão do onus probandi, consoante será demonstrado no tópico a seguir, no tocante à mitigação da carga probatória.

Além do recurso à inversão do ônus da prova, outros critérios são utilizados no sentido de avaliação da probabilidade. O que importa destacar é que o magistrado deve agir com racionalidade e mediante motivação, afastando meras especulações.

Entre os critérios possíveis, destaca-se a probabilidade estatística, que permite o alcance de resultados aproximados aos que seriam verdadeiramente alcançados caso ocorresse uma situação concreta. Nesse sentido Caitlin Sampaio Mulholland assevera que:

A ciência estatística admite, portanto, que se determine na responsabilidade civil, com um grau de certeza elevado- ainda que não absoluto -, que uma determinada atividade ou conduta é causa de apontado dano, devido a sua incidência ou propensão para gerá-lo. Por exemplo, sem em 70 casos de 100 examinados verificou-se que o resultado ocorreu da mesma maneira como se deu no caso questionado, presume-se que exista aí uma relação de causa e efeito. $[\ldots]^{572}$

$\mathrm{Na}$ presunção de responsabilidade por probabilidade estatística, será estabelecido o percentual aceito de que determinada conduta levará ao resultado dano, através da análise de todas as condições que comumente, ordinariamente ou provavelmente poderia causar o dano. Abaixo transcrevemos ilustração:

571. A presunção no Direito, especialmente no Direito Civil. In: STOCO, Rui; MENDES, Gilmar Ferreira. Doutrinas Essenciais de Direito Civil. Vol. 5. São Paulo: Editora Revista dos Tribunais, 2014, p. 1323.

572. MULHOLLAND, Caitlin Sampaio. A responsabilidade civil por presunção de causalidade. Rio de Janeiro: GZ, 2010, p. 300. 
Tomemos como exemplo a seguinte hipótese: uma pessoa desenvolve uma doença (câncer) após o consumo de determinado medicamento. Apesar de não ser a ela possível determinar a relação de causa e efeito entre o dano sofrido (câncer) e o efeito do medicamento, poderá o juiz considerar, através de uma análise de presunção, que o dano foi gerado pelo consumo do remédio. ${ }^{573}$

A probabilidade estatística, na lição de Pietro Trimarchi, ${ }^{574}$ é juridicamente relevante quando é suficientemente alta para justificar um juízo de reprovabilidade social da conduta ou atividade, levando-se em consideração a utilidade e finalidade destas e o custo com a eliminação dos riscos advindos da exploração da atividade e da realização da conduta.

Portanto, com relação à utilização da técnica, a mesma somente será possível falar em probabilidade estatística naqueles casos em que há uma grande quantidade de eventos semelhantes. Nisto resulta a sua maior desvantagem, pois ela depende, para ser aplicada, de um grande número de paradigmas para comparação.

Ressalta-se que para o emprego da probabilidade baseado em estatística não se requer a utilização de prova pericial, podendo ser utilizadas pesquisas que realizam de forma recorrente o exame de probabilísticas sobre a ocorrência de determinadas consequências danosas.

Outra técnica para apurar probabilidades é a lógica. Enquanto a probabilidade estatística é demonstrada de forma científica, objetiva, empírica, inclusive com o emprego de cálculos; a probabilidade lógica depende, por óbvio, da interpretação do magistrado acerca da ocorrência dos resultados supostamente danosos que se pretende ver indenizados, que irá estabelecer uma conexão de causa e efeito entre o resultado danoso e a conduta ou atividade, com o emprego de razoabilidade. ${ }^{575}$

Referidas técnicas não precisam existir cumulativamente, podendo ser destacadas separadamente ou de forma alternativa no sentido de presumir a existência do

573. MULHOLLAND, Caitlin Sampaio. A responsabilidade civil por presunção de causalidade. Rio de Janeiro: GZ, 2010, p. 298.

574. Causalità e danno. Milano: Giuffrè, 1967, p. 51.

575. MULHOLlAND, Caitlin Sampaio. A responsabilidade civil por presunção de causalidade. Rio de Janeiro: GZ, 2009, p. 307. 
nexo causal. Porém, ambas contribuem para que a incerteza dos riscos não sejam óbices para uma avaliação necessária acerca de sua evitabilidade, bem como indenizabilidade.

\subsubsection{COMPROVAÇÃO DE RISCOS E A MITIGAÇÃO DA CARGA PROBATÓRIA NA JURISPRUDÊNCIA}

O recurso à presunção para identificação do nexo de causalidade opera a favor do lesado, auxiliando-o na demonstração da prova deste pressuposto da responsabilidade civil.

Uma das técnicas presuntivas é justamente a aplicação da inversão do ônus da prova, admitida por alguns tribunais, em uma aplicação dinâmica do encargo probatório.

A distribuição do ônus da prova, em perfil estático, é disciplinada no art. 333 do Código de Processo Civil, incumbindo ao autor o encargo de provar fato constitutivo do seu direito, enquanto ao réu incumbe demonstrar os fatos extintivos ou obstativos das alegações de defesa do autor. De orientação liberal, fundada nos postulados de segurança jurídica e previsibilidade, não é admissível que o Poder Judiciário flexibilize a imposição legal.

Referido rigor, na atualidade, não mais se justifica, diante da Constituição Federal, que reconhece o acesso à justiça como direito fundamental. O reflexo dessa concepção no processo civil permite que os seus instrumentos adaptem-se aos objetivos de direito material contemplados no caso tratado, o que permite uma adaptação funcional, para assegurar uma igualdade substancial entre as partes, com o reconhecimento de que certas circunstâncias apresentam extrema dificuldade probatória.

A importância de se avaliar a possibilidade real das partes em relação ao ônus da prova, juntamente com as características do direito material envolvido, como é o 
caso dos riscos certos ou incertos e violação de deveres legais, ${ }^{576}$ demandam uma atribuição diferenciada, consubstanciada na teoria da atribuição dinâmica do ônus da prova. Alias, o Código de Defesa do Consumidor, em seu art. $6^{\circ}$, VIII, traz regra inspirada nesse conceito, ao permitir ao juiz a inversão do ônus diante da hipossuficiência do consumidor. Constatado um desequilíbrio entre as partes no tocante à capacidade de se desincumbir do encargo probatório, o juiz poderá afastar a aplicação da distribuição estática, sob pena de violação de direito fundamental.

A partir dessa possibilidade, os princípios da precaução e da prevenção oferece ao juiz o fundamento para que possa adequar o direito material às situações concretas, e garantir um processo justo, avaliando em situações reais a extensão da dificuldade na produção de prova, para conferir a quem possua maior informação a sua

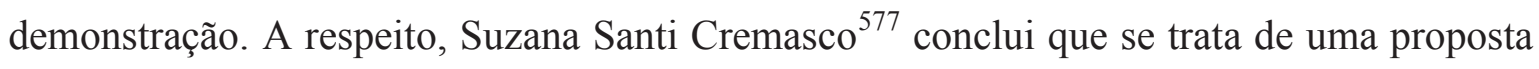
condizente com a natureza instrumental do processo e dos institutos a ele afins, que, ao estimular a produção da prova e o esclarecimento de todos os fatos do litígio, possibilita a descoberta da verdade real, evita a ocorrência do non liquet e, ainda, permite que a decisão exarada seja uma decisão efetiva e justa, apta a tutelar adequadamente o direito material.

A dinamização do ônus da prova pode ser realizada de ofício, embora ausente a sua previsão legal (exceto no CDC), em razão da Constituição Federal, a fim de evitar violação aos direitos fundamentais.

Este entendimento já tem sido adotado pela jurisprudência nacional. Admitindo a inversão do ônus da prova, por influência do princípio da precaução, transcrevemos a seguir de decisão do Superior Tribunal de Justiça:

[..] percebo que a análise do ônus da prova, em ação coletiva por dano ambiental, deve ser dirimida pela interpretação das leis aplicáveis ao mencionado instrumento processual à luz dos princípios norteadores do Direito Ambiental. Isso porque, em regra, a inversão do ônus probatórios deve assentar-se exclusivamente em disposição expressa de lei. Mas, no presente caso, encontra fundamento essa inversão também em princípios transversais do ordenamento jurídico, quais sejam, os princípios ambientais. No plano legal, destaco os dispositivos que guardam relação direta com a questão posta em discussão: CDC, art. $6^{\circ}$,

\footnotetext{
576. MARINONI, Luiz Guilherme; ARENHART, Sergio Cruz. Curso de Processo Civil. v. 2. 6. ed. São Paulo: Revista dos Tribunais, 2007, p. 268.

577. A distribuição dinâmica do ônus da prova. Rio de Janeiro: GZ, 2009, p. 75.
} 
VIII (...); Lei 7.347/85, art. 21 (...); CC, art. 927, parágrafo único (...). No caso das ações civis ambientais, entendo que o caráter público e coletivo do bem jurídico tutelado - e não a eventual hipossuficiência do autor da demanda em relação ao réu, nos leva à conclusão de que alguns dos direitos do consumidor também devem ser estendidos ao autor daquelas ações, afinal essas buscam resguardar (e muitas vezes reparar!) o patrimônio público de uso coletivo, consubstanciado no meio ambiente. A essas normas agrega-se o Princípio da Precaução. Esse preceitua que o meio ambiente deve ter em seu favor o benefício da dúvida no caso de incerteza (por falta de provas cientificamente relevantes) sobre o nexo causal entre determinada atividade e um efeito ambiental negativo. Incentiva-se, assim, a antecipação de ação preventiva, ainda que não se tenha certeza sobre a sua necessidade e, por outro lado, proíbe-se as atuações potencialmente lesivas, mesmo que essa potencialidade não seja cientificamente indubitável. Além desse conteúdo substantivo, entendo que o Princípio da Precaução tem ainda uma importante concretização adjetiva: a inversão do ônus da prova". ${ }^{578}$ (grifos nossos).

Essa decisão demonstra de forma bastante salutar a aplicação da teoria da carga dinâmica da prova, de especial utilidade para aqueles casos de danos cuja ocorrência ou extensão seja de difícil comprovação, em virtude de seus efeitos somente se manifestarem ao longo de um tempo ou aqueles que têm alcance transfronteiriço.

Mas não são apenas casos de direito ambiental que autorizam a aplicação desse entendimento. O Tribunal de Justiça do Paraná, considerando os riscos decorrentes de mau atendimento de plano de saúde, também utilizou referida teoria. Para ilustrar, segue trecho do voto:

[...] Aduz a autora que diante da situação de urgência de seu marido e tendo em vista que após consulta com diversos médicos credenciados pela requerida, e devido a gravidade do estado clínico do paciente, houve a manifestação negativa ao acompanhamento do tratamento oncológico [...] Na situação em tela, observa-se que a parte autora demonstra ter buscado todo o tratamento posto a disposição para reverter ou amenizar o quadro clínico de seu esposo, restando evidente a situação de emergência pelo grau de evolução da doença: "sofrimento do paciente se devia a compreensão dos nervos da coluna já que as vértebras que sofreram metástases estavam em colapso.” [...] Sopesada tal consideração, tem-se que a parte autora, ora apelante, apresentou aos autos documentos para demonstrar a necessidade de internação em hospital não credenciado - invocando, assim, os fatos constitutivos de seu direito. Destarte, caberia à parte requerida, na condição de prestadora de serviços e que, em tese, detêm maior habilidade técnica para comprovar suas alegações,

578. STJ, Recurso Especial no 972.902 - RS (2007/0175882-0). 
desconstituir os fatos alegados na petição inicial - o que não fez. [...] Este entendimento está consagrado naquilo que chamamos de Teoria da Distribuição Dinâmica dos Ônus Probatórios [...] Desta feita, observada a regra contida no art. 333, II, do CPC, bem como a Teoria da Carga Dinâmica das Provas, verifico que, no caso em apreço, a tese declinada pela parte autora não restou desconstituída, ou seja, a parte apelada/requerida em momento algum produziu qualquer prova eficaz no sentido de demonstrar que o quadro clínico do esposo da autora não era emergencial [...]. ${ }^{579}$

Desse modo, a dificuldade de comprovação de riscos em situações especiais concretas, é capaz de autorizar a mitigação da carga probatória no sentido de reequilibrar os respectivos encargos.

Cabe, por fim, uma advertência. Não se defende que o emprego do recurso à inversão do ônus estabeleça para o réu o encargo de fazer provas impossíveis ou "diabólicas". Tal ensejo é um mecanismo excepcional, e aplicável mediante fundamentação do juiz. ${ }^{580}$

\subsubsection{TEORIA DA CAUSALIDADE POR COTA NO MERCADO (MARKET SHARE LIABILITY) E O CASO DO ESTROGÊNIO SINTÉTICO}

Os problemas apresentados pela identificação e comprovação do nexo de causalidade têm forçado a criação de soluções para a sua superação. Assim, nos Estados Unidos, foi forjada uma teoria que identifica na participação de cotas no mercado potenciais causadores de dano.

Referida teoria foi utilizada no caso do estrogênio sintético (DES), que nos servirá como paradigma. Entre os anos 50 a 70, diversas empresas do ramo de farmácia

579. Brasil - TJ-PR 9166029 PR 916602-9 - Relator: José Sebastiao Fagundes Cunha, Data de Julgamento: 06/09/2012, $8^{\text {a }}$ Câmara Cível.

580. Teresa Ancona Lopes observa que “[...] além desse mecanismo ser excepcional, e devendo vir fundamentada pelo juiz a decisão favorável à inversão, não poderá o magistrado, no uso do seu poder discricionário, pedir que o réu faça provas impossíveis [...] É o caso da inversão da prova que pedisse que a indústria tabageira provasse que o cigarro não faz mal e não causa dependência. Isso não pode ser provado porque todos sabem, principalmente os fumantes, que o cigarro faz mal e causa dependência, e o fumante conscientemente assume esse risco". LOPEZ, Teresa Ancona Nexo causal e produtos potencialmente nocivos: a experiência brasileira do tabaco. São Paulo: Quartier Latin, 2008, p. 172. 
inseriram no mercado uma droga antiabortiva composta pelo DES. No decorrer da sua comercialização no mercado americano, não havia a possibilidade científica de prever por completo o eventual desenvolvimento de anormalidades. Anos após, constatou-se que a substância era responsável pela ocorrência de casos de câncer nas crianças cujas mães utilizaram o medicamento.

É possível identificar, desde logo, que os efeitos verificados caracterizam o risco do desenvolvimento, pois trata de caso em que um determinado produto foi desenvolvido e inserido no mercado de consumo, sem que à época fosse possível detectar, através dos meios técnicos e científicos existentes, o seu defeito.

Este caso oferece as destacadas dificuldades: a) a comprovação de nexo causal, pois anos após, a consumidora sequer se lembrava de qual era especificamente a empresa farmacêutica que ofereceu o produto; b) entre tantas empresas que forneciam o mesmo remédio, qual deveria indenizar?

A solução jurídica encontrada foi responsabilizar todos os fabricantes de DES pelos danos causados por seu consumo, conforme as respectivas cotas de participação no mercado consumidor americano (market share liability).

O emprego dessa teoria é importante para ressaltar um fato - o afastamento da necessidade de prova do nexo causal, e a consideração de que a prova da proporcionalidade é suficiente para estabelecimento de responsabilidade.

Assim, a vítima não precisa demonstrar a existência do nexo de causalidade entre o dano e a conduta de um determinado fabricante do medicamento. Basta que identifique os produtores da droga e a sua cota de participação no mercado para que se alcance a função da investigação e o reconhecimento do nexo de causalidade, para assim se imputar as consequências danosas.

Caitlin Sampaio Mulholland ${ }^{581}$ elenca alguns pressupostos que devem seguir esta teoria sob pena de se tornar um tanto ampla, quais sejam: a) o produto deve ser fungível, uma vez que cada uma de suas unidades deve ser por si só suficiente para causar o risco do dano; b) a impossibilidade objetiva de identificar o causador do dano. A vítima 
deverá na ação de responsabilização demonstrar que tomou todas as medidas para identificar o causador e suas tentativas restou frustradas; c) a inexistência de excludentes de responsabilidade (por exemplo: um dos pretensos responsáveis comprovar que o produto não foi exposto ao mercado ou que não inseriu em determinada área, ou em determinada data etc.); d) a demanda deve ser dirigida contra pessoas que tenham uma participação considerável no mercado; e) o produto deve ser intrinsecamente perigoso; f) o produto deve produzir um sintoma típico identificado como sendo o resultado de seu uso; g) a vítima deve ter sido exposta ao produto.

Na Espanha, entendimento no mesmo sentido foi aplicado no caso entre Grünenthal Pharma S.A. e "Avite” (Associação das vítimas da Talidomida na Espanha), na primeira sentença espanhola que julgou caso de responsabilidade civil referente ao uso do medicamento, em 2012. ${ }^{582}$ Contudo, o argumento utilizado foi o da "solidariedade imprópria".

Como é sabido, a solidariedade é baseada em um regime contratual ou imposição legal expressa. Em que pesem referidas características, também presentes no ordenamento espanhol, a opção realizada pela jurisprudência espanhola é aplicar o regime das obrigações solidárias a situações em que duas ou mais pessoas tenham causado dano e não seja possível discernir qual é a cota de responsabilidade de cada um. Referida solidariedade é aplicada em situações de danos causados por vários agentes, sendo que estes podem ter atuado de forma sucessiva ou conjunta. De forma semelhante à solidariedade de origem contratual, essa solidariedade imprópria acarreta a cada um dos codevedores do mesmo dano os riscos da insolvência de alguns deles e o encargo de identificar e buscar regressivamente as cotas individuais que corresponde a cada um. Também impede a exceção de litisconsórcio passivo necessário. A vítima poderá demandar a um, a vários ou a todos os corresponsáveis, e a sentença de condenação pode ser executada com relação ao patrimônio de qualquer dos condenados.

582. CODERCH, Pablo Salvador. Daños tardíos Avite c. Grünenthal. Comentario a la SJPI no 90 Madrid, 19.11.2013, sobre los daños causados por la talidomida. InDret. Revista para el análisis del derecho. Disponível em: < $\underline{w w w . i n d r e t . c o m}>$. Acesso em: 05 jan./2014.

583. Este critério de imputação não está imune a críticas, tal como a exposada por Ana Perestrelo de Oliveira: "São de rejeitar vias como a já aludida pollution share liability - que, para além de duvidosa no seu ordenamento de origem, questiona frontalmente princípios basilares do nosso sistema jurídico, não se configurando mesmo como verdadeira fórmula de imputação". Causalidade e imputação na responsabilidade civil ambiental. Coimbra: Almedina, 2007, p. 65. 
Trata-se de uma medida evidentemente pro damnato, ao permitir o acesso à indenização sem que a efetiva causalidade e extensão da responsabilidade estejam precisamente identificadas. ${ }^{583}$

No Brasil não há relatos de casos em que se tenha utilizado o critério da cota de mercado como forma de estabelecer a responsabilidade. Contudo, a exposição do caso demonstra que a interpretação jurídica foi desenvolvida com inspiração na presunção de causalidade. Considerando que a preocupação atual é voltada à vítima, o emprego desta teoria é um recurso para que não se veja impossibilitada de ser indenizada por dificuldades específicas em demonstrar o nexo de causalidade.

A relação dessas hipóteses ilustradas com a função preventiva prospectiva parte do princípio de que o elemento negativo que atua como obstáculo à responsabilização - a certeza, não excusa um elemento positivo - a ameaça ou existência de risco. ${ }^{584}$ Assim, embora o princípio da precaução gere no magistrado uma menor convicção, pois as propriedades exigidas para ser considerado causam jurídicas não estão presentes de forma absoluta, o recurso ao emprego de probabilidade é capaz de suplantar esta dificuldade. Assim, diante da presença de um risco intolerável, a partir do estabelecimento de presunções, antes mesmo que a referida incerteza venha a se tornar um dano efetivo, é possível o juiz se valer de medidas preventivas a fim de evitá-lo.

Para além disso, se adotada a compreensão de que o risco pode, em si mesmo, reunir as condições para que seja indenizável, consoante tratamos no capítulo referente ao dano, a análise de causalidade a partir de presunções permitirá ao julgador estabelecer a respectiva responsabilidade, haja vista que, com relação à responsabilidade retrospectiva tal possibilidade já é empregada. De recordar-se que espécies de diminuição de carga probatória não são estranhas à ciência jurídica, posto que já reconhecidas e empregadas com relação às medidas cautelares, e também com relação às medidas auto satisfativas. Para estabelecer um comparativo, é a presença do fumus boni iuris recomendado pela precaução, o elemento necessário para que seja estabelecida a causalidade por presunção. Com este enfoque preventivo, diante da constatação de riscos, é prevención, minimización de costos sociales. Buenos Aires: AbeledoPerrot, 2009, p. 163. 
que o Tribunal de Justiça de São Paulo concedeu tutela antecipada para remoção de moradores em área de risco:

Ação Civil Pública. Antecipação de tutela deferida para remoção dos moradores de área de alto risco e alojamento em local adequado, com inserção das famílias em programas habitacionais. Multa diária. Possibilidade. Relatório e fotografias que dão conta da existência de risco de desabamento e precariedade das construções que reclamam providências urgentes. Problemas que acompanham os moradores há anos. Obrigação do Município que decorre do dever constitucional de promover o adequado planejamento e controle do parcelamento, uso e ocupação do solo urbano (artigos 30, VIII e 182). ${ }^{585}$

\subsection{RISCOS DO DESENVOLVIMENTO COMO EXCLUDENTE DE RESPONSABILIDADE: UMA OPÇÃO DE POLÍTICA LEGISLATIVA}

Passa-se, neste momento, a enfrentar a análise acerca dos danos tardios gerados pelos riscos do desenvolvimento. Para James Marins, os riscos de desenvolvimento se caracterizam:

[...] na possibilidade de que um determinado produto venha a ser introduzido no mercado sem que possua defeito cognoscível, ainda que exaustivamente testado, ante o grau de conhecimento científico disponível à época de sua introdução, ocorrendo todavia, que, posteriormente, decorrido determinado período do início de sua circulação no mercado de consumo, venha a se detectar defeito, somente identificável ante a evolução dos meios técnicos e científicos, capaz de causar danos aos consumidores. ${ }^{586}$

Do exposto, duas características se extraem acerca de sua verificabilidade: a) caráter defeituoso do produto; b) desconhecimento, no momento em que foi colocado em circulação, acerca de sua potencialidade danosa. Exemplo sempre lembrado é o do desastre farmacêutico causado pelo medicamento Talidomida. No caso das vítimas

585. Brasil - Tribunal de Justiça de São Paulo - Agravo de Instrumento no 2029866-68.2013.8.26.0000, da Comarca de São Paulo - Rel. Edson Ferreira - Data do julgamento: 12 de março de 2014.

586. Responsabilidade da empresa pelo fato do produto. São Paulo: Editora Revista dos Tribunais, 1993, p. 67. 
brasileiras, o governo sancionou lei concedendo pensão alimentícia vitalícia. ${ }^{587}$

Por sua vez, segundo Antônio Hermann V. Benjamin ${ }^{588}$ os riscos de desenvolvimento são

[...] aqueles riscos que não podem ser cientificamente conhecidos ao momento do lançamento do produto no mercado, vindo a ser descoberto somente após certo período de uso do produto e do serviço" [...] "é defeito que, em face do estado da ciência e da técnica à época da colocação do produto ou serviço em circulação, era desconhecido e imprevisível.

Da definição exposta acima, extrai-se uma das questões mais tormentosas na análise do tema, qual seja, a definição do "estado dos conhecimentos científicos e técnicos" (state of the art), para a avaliação como excludente ou não do nexo de causalidade.

O critério utilizado para a identificação do estado da ciência e da técnica deve ser objetivo, similar a de qualquer outro do mundo, e não com relação a determinado fabricante em particular. De outro lado, em consideração ao dever de segurança, não são relevantes as dificuldades particulares que cada produtor apresenta com relação à existência dos defeitos, que deve se manter a par do estágio de conhecimento técnico e científico daquela determinada época. Por esta razão João Calvão da Silva recorda que o produtor "tem de estar sempre atualizado, a par das experiências científicas e técnicas mundiais, conhecedor da literatura nacional e internacional da especialidade, do mais avançado estado da ciência e da técnica mundiais". 589

De outro turno, os riscos do desenvolvimento também não se confundem com a legítima expectativa do consumidor com relação à qualidade e segurança do produto. Em consequência, a evolução tecnológica e científica permanente, que ano após ano, apresenta ao mercado um novo modelo de veículo, celular, televisor, fórmulas para

587. Lei no $7.070 / 82$ - Art $1^{\text {o }}$ - Fica o Poder Executivo autorizado a conceder pensão especial, mensal, vitalícia e intransferível, aos portadores da deficiência física conhecida como 'Síndrome da Talidomida' que a requererem, devida a partir da entrada do pedido de pagamento no Instituto Nacional de Previdência Social - INPS.

588. BENJAMIN, Antônio Herman V; MARQUES, Claudia Lima; BESSA, Leonardo Roscoe. Manual de direito do consumidor. 2. ed. rev., atual. e ampl. São Paulo: Editora Revista dos Tribunais, 2009, p. 169.

589. Responsabilidade civil do produtor. Almedina: Coimbra, 1990, p. 189. 
embelezamento, medicamentos, entre outros, ainda que resulte em maior qualidade ou segurança que os respectivos modelos anteriores, não caracterizam o defeito pressuposto (artigos $12, \S 2^{\circ}$ e $14, \S 2^{\circ}$, do Código de Defesa do Consumidor). ${ }^{590}$

No Direito Europeu, a Diretiva 85/374/CEE expressamente estabeleceu os riscos do desenvolvimento como causa de exclusão da responsabilidade do produtor, em seu art. $7^{\circ}$, alínea "e". 591

Durante o processo de elaboração da diretiva, surgiram correntes opostas em relação à problemática dos riscos do desenvolvimento. De um lado, estavam os países como a Bélgica, a Dinamarca, a Grécia, a França, a Irlanda e Luxemburgo, que pretendiam eliminar do texto da Diretiva esta causa de exclusão da responsabilidade, sob o argumento de que se os riscos recaíssem sobre o produtor este poderia repercuti-los no custo do seguro e no preço dos produtos, e tal custo seria repassado aos consumidores. De outro lado, países como Itália, os Países Baixos e o Reino Unido, defendiam a permanência desta excludente, invocando o impacto negativo que a não exclusão teria sobre a investigação e o desenvolvimento de produtos de alta tecnologia e o previsível agravamento do custo do seguro de responsabilidade civil. ${ }^{592}$

Diante dessa ausência de unanimidade, a Diretiva ${ }^{593}$ deixou livre a possibilidade de exclusão ou não em seus respectivos ordenamentos internos, sobre a previsão de responsabilidade nas situações de defeitos de desenvolvimento. Concedida a liberalidade, a Alemanha, por exemplo, não permite a excludente dos riscos de desenvolvimento nas hipóteses específicas de produtos farmacêuticos. A França, por sua vez, adotou o disposto na Diretiva, por meio da Lei $\mathrm{n}^{\circ}$ 98-389, de 18 de maio, consagrando como causa de exoneração os riscos de desenvolvimento, excluindo, de seu âmbito de

590. SANSEVERINO, Paulo de Tarso Vieira. Responsabilidade civil no Código de Defesa do Consumidor e a defesa do fornecedor. $3^{\text {a }}$ ed. São Paulo: Saraiva, 2010, p. 340.

591. Art. $7^{\circ}$ - O produtor não é responsável nos termos da presente diretiva se provar: (...) e) que o estado dos conhecimentos científicos e técnicos no momento da colocação em circulação do produto não lhe permitiu detectar a existência do defeito.

592. SILVEIRA, Diana Montenegro da. Responsabilidade civil por danos causados por medicamentos defeituosos. Coimbra: Coimbra, 2010, p. 58.

593. Dispõe o art. 15 da referida Diretiva: 1. Qualquer Estado-membro pode: (...) b) Em derrogação da alínea "e" do artigo $7^{\circ}$, manter ou, sem prejuízo do procedimento definido no $\mathrm{n}^{\mathrm{o}} 2$, prever na sua legislação que o produtor é responsável, mesmo se este provar que o estado dos conhecimentos científicos e técnicos no momento da colocação do produto em circulação não lhe permitia detectar a existência do defeito. 
aplicação quando o dano é causado em relação a elementos do corpo humano. A Espanha foi outro país que adotou os riscos de desenvolvimento como causa exonerativa de responsabilidade, por meio da Lei $n^{\circ}$ 22/1994, de 6 de julho, também excepcionando a responsabilidade quando se tratar de medicamentos, alimentos ou produtos alimentares destinados ao consumo humano. Portugal, a seu turno, limitou-se a repetir o disposto na alínea "e" do art. $7^{\circ}$ da Diretiva $85 / 374$, por meio de sua lei $131 / 2001^{594}$, não prevendo qualquer excludente.

A discussão do tema também alcançou o território brasileiro, pois o ordenamento brasileiro não o refere expressamente. Por sua vez, os preceitos contidos no Código de Defesa do Consumidor permitem posicionamentos doutrinários nos dois sentidos.

Os posicionamentos desfavoráveis ${ }^{595}$ à previsão como excludente, apresentam, em síntese, as seguintes razões: a) o produtor goza dos benefícios de colocar no mercado um produto inovador e bem sucedido, auferindo os lucros e os benefícios dele decorrente, deve também suportar os seus riscos; b) o produtor pode se resguardar por meio da contratação de seguro e imputar os gastos com os respectivos prêmios no preço dos produtos; c) a imputação de responsabilidade ao produtor, mesmo no caso de danos provocados por defeito de desenvolvimento do produto, levaria a uma maior atenção por parte deste à qualidade e segurança dos produtos que coloca no mercado (efeito preventivo/precaucional); d) no caso de medicamentos, deve prevalecer a proteção das vítimas, uma vez que os medicamentos podem causar efeitos colaterais e com consequências muitos; e) os riscos de desenvolvimento devem ser considerados como fortuito interno, ou seja, risco inerente à atividade do fornecedor, o que, portanto, afasta a possibilidade de ser uma excludente de responsabilidade; f) os riscos de desenvolvimento não constam expressamente dentre as causas excludentes previstas no artigo $12, \S 3^{\circ}$ do CDC, razão pela qual não podem ser admitidos como tal; g) conforme o artigo 10 do CDC,

594. Dispõe o art. $5^{\circ}$ da lei portuguesa $n^{\circ}$ 131/2001: O produtor não é responsável se provar que o estado dos conhecimentos científicos e técnicos, no momento em que pós o produto em circulação, não permitia detectar a existência de defeito.

595. Adotados por doutrinadores como BENJAMIN, Antônio Herman V.; MARQUES, Claudia Lima; BESSA, Leonardo Roscoe. Manual de direito do consumidor. 2. ed. rev., atual. e ampl. São Paulo: Editora Revista dos Tribunais, 2009; CAVALIERI FILHO, Sérgio. Programa de direito do consumidor. São Paulo: Atlas, 2009; CALIXTO, Marcelo Junqueira. A responsabilidade civil do fornecedor de produtos pelos riscos do desenvokvimento. Rio de Janeiro: Renovar, 2004. 
segundo o qual “o fornecedor não poderá colocar no mercado de consumo produtos ou serviços que sabe ou deveria saber apresentar alto grau de nocividade ou periculosidade à saúde ou segurança", não se pode excluir a responsabilidade.

Já os argumentos em defesa ${ }^{596}$ de sua previsão como excludente podem ser avaliados: a) excessiva penalização do produtor ao responsabilizá-lo por defeitos que eram incognoscíveis segundo o mais avançado estado da ciência e da técnica quando da colocação do produto no mercado, o que provocaria um impacto negativo no progresso científico; b) dificuldade de contratação de seguros se a responsabilidade por riscos de desenvolvimento lhes fosse imputada; c) a exclusão por riscos de desenvolvimento corresponde ao interesse dos próprios consumidores em ter à disposição produtos cuja fabricação é consentida, embora haja certa margem de risco no seu emprego; d) onerar o fabricante por danos futuros, ainda que o produto, ao ser colocado no mercado, tenha se mostrado adequado, desestimularia as indústrias à pesquisa, ao investimento, ou tornaria a atividade excessivamente onerosa e sem competitividade; e) haveria dificuldades no estabelecimento de estratégias de indenização aos consumidores por eventual dano produzido por produto cujos riscos eram impossíveis de prever à época do seu lançamento; f) a assunção de riscos pelo desenvolvimento encareceria muito o preço final de produtos essenciais, como medicamentos, ${ }^{597} \mathrm{~g}$ ) com fundamento no art. $10, \S 1^{\circ}$ do CDC, argumentase que o produto considerado perigoso apenas impõe o dever de informar.

A importância do dever de informação já foi abordada em distintas passagens nesta pesquisa, como reflexo da influência dos princípios da precaução e da prevenção. Em determinadas situações, como por exemplo os danos originários do tabaco, é possível que a informação seja considerada para afastamento do nexo de causalidade, diante da presença do defeito de informação. ${ }^{598}$

Associando os riscos do desenvolvimento ao princípio da precaução, Teresa

596. Defendidos por doutrinadores como TEPEDINO, Gustavo. A responsabilidade civil por acidentes de consumo na ótica civil-constitucional. Temas de direito civil. Rio de Janeiro: Renovar, 1999, p. 242 e MARINS, James. Responsabilidade da empresa pelo fato do produto. São Paulo: Editora Revista dos Tribunais, 1993.

597. SILVA, João Calvão da. Compra e venda de coisas defeituosas: conformidade e segurança. Coimbra: Almedina, 2001, p. 99.

598. LOPEZ, Teresa Ancona. Princípio da Precaução e Evolução da Responsabilidade Civil. São Paulo: Quartier Latin, 2010, p.103. 
Ancona Lopez ${ }^{599}$ conclui que:

Chegamos à conclusão que admitir o risco de desenvolvimento como excludente não põe em risco a segurança dos produtos. A segurança é obrigatória sempre e, no caso, o defeito somente apareceu depois de certo prazo do produto no mercado. Quando foi lançado apresentava a segurança esperada segundo o state of the art. A segurança é requisito prévio e a excludente por risco de desenvolvimento somente se dá a posteriori do dano. O risco de desenvolvimento somente vem demonstrar que o risco está em toda parte na sociedade contemporânea.

Avaliados todos os argumentos, encontramos apoio na opinião de que, no Brasil, não há possibilidade dos riscos do desenvolvimento serem interpretados como exclusão de causalidade, inicialmente, com base no art. 12 do $\mathrm{CDC}$, que pressupõe a existência de defeito do produto. Diante disso, a possibilidade do produtor eximir-se dependeria de previsão expressa como hipótese de rompimento, o que não se verifica no rol do parágrafo único do referido art. 12. Igualmente, o art. 931 do Código Civil não traz essa possibilidade. Essa é a opção de política legislativa adotada no ordenamento brasileiro.

Ademais, a adoção dos riscos do desenvolvimento como excludente não estaria consentâneo com os valores delineados na Constituição Federal, que além de determinar a atuação estatal, também limitam as ações dos particulares. Com efeito, a tutela do consumidor é garantida expressamente pela Constituição Federal de 1988 no capítulo dos direitos e garantias fundamentais, artigo $5^{\circ}$, inciso XXIII, o que denota o reconhecimento da vulnerabilidade do consumidor, exigindo a intervenção do Estado nas relações consumeristas. Além disso, o artigo 170, inciso $\mathrm{V}, \mathrm{CF} / 88$, ao assegurar a defesa do consumidor como princípio fundamental da ordem econômica, irradia valor no sentido de tutelar o consumidor diante do poderio econômico do fornecedor. Sem olvidar, obviamente, da tutela da dignidade da pessoa humana, esculpida no inciso III, artigo $1^{\circ}$, da Constituição brasileira.

Como já exposto no decorrer deste trabalho, os deveres fundamentais e a necessidade de proteção de bens jurídicos fundamentais, em conjugação com os princípios da precaução e da prevenção, geram responsabilidades que não se limitam à reparação de 
danos, mas sim em uma atuação promocional de toda a sociedade, com inclusão dos produtores e fornecedores, para a garantia de segurança e proteção dos consumidores das gerações presentes e vindouras. 


\section{CONCLUSÃO}

\section{UMA PROPOSTA DE MODELO OPERATIVO PARA A Responsabilidade Civil Preventiva}

No desfecho das pesquisas realizadas, impõe-se em derradeira exposição, a conclusão do tema a que nos dispomos a enfrentar.

A concepção primeira da responsabilidade civil valia-se de modelo estruturado através de pressupostos invencíveis e subsequentes (conduta, nexo causal e dano) e de metodologia jurídica única, apta ao escopo de reparação (reflexo de visão patrimonialista), imprimindo para tanto assunção de perspectiva retrospectiva (ex post). No campo da teoria geral do direito, é perceptível que essa metodologia de escopo único tem origem no monismo normativista, onde o culto à norma se sobrepõe aos valores de justiça e solidariedade, impedindo o Direito, enquanto sistema jurídico, abrir-se em interdisciplinaridade e em ampla cognoscibilidade com as demais ciências (sociais, econômicas, políticas, biológicas, tecnológicas, informacionais etc.).

As alterações de paradigmas, após as codificações primárias, para o advento do Estado Social, no campo da responsabilidade civil, foi protagonizado pela passagem do subjetivismo (na análise da culpa como a má utilização da liberdade) para o objetivismo (atividade que incute risco intolerável ou mediante especificações legais).

Mesmo nesse novo ambiente, os esquemas de estrutura, dedução e análise retrospectiva não podem ser desprezados, já que permanecem úteis aos propósitos obrigacionais, quer na análise do caso concreto, quer no empréstimo de inerente experiência, inclusive jurisprudencial, a outros modelos de responsabilidade civil. Observa-se, no entanto, o surgimento de uma reação jurídica para além da mera reparação, com a assunção de novos valores expressos em deveres e direitos fundamentais nas Constituições democráticas, bem como em normas de esfera infraconstitucional, que compreendem situações jurídicas subjetivas existenciais e de promoção ao vulnerável, especialmente no aspecto difuso.

Corresponde à pós-modernidade, no âmbito da responsabilidade civil, a 
teoria da argumentação, oportunidade em que os princípios (no caso, da precaução e da prevenção) ganham projeção através da evitabilidade de danos geralmente irreversíveis, tanto do ponto de vista existencial, como da perspectiva patrimonial. Neste caso, o que se busca é maior densidade valorativa, bem como eficácia normativa.

O princípio da prevenção, no âmbito da responsabilidade civil, é observado tanto na inafastabilidade do Poder Judiciário para evitar lesão ou ameaça de direitos (art. $5^{\circ}$, inciso XXV, CF/88), bem como nos direitos da personalidade (art. 12, CC), e ainda, nos microssistemas de tutela aos vulneráveis (CDC e outros), sendo caracterizado pelos riscos certos, de potencial efeito danoso, para evitar lesão ao interesse juridicamente tutelável.

A seu turno, o princípio da precaução, na seara da responsabilidade civil, pode ser contemplado constitucionalmente na vedação de exposição a riscos que levem à extinção da fauna e da flora (art. 225, $\S 1^{\circ}$, inc. VI, CF/88); na exigência de maior prudência pela sociedade (art. 186, CC) e ainda, na legitimidade das atividades desenvolvidas ante ao exercício inadmissível de posição jurídica (art. 187, CC), afora leis micro protetivas setoriais (como no caso da Lei de Resíduos Sólidos e Lei dos Desastres), sendo caracterizado pelo risco incerto e que deveria ter sido gerenciado por quem o colocou no mercado.

É estruturado pelos princípios acima referidos e ambientado na pósmodernidade, na qual a sociedade é múltipla em riscos e incertezas, ao mesmo tempo em que almeja segurança, que a Responsabilidade Civil Preventiva possui ampla aplicabilidade, para a salvaguarda de direitos e bens fundamentais, por sua vez em observância a deveres fundamentais (de precaução e prevenção). A potência normativa da responsabilidade civil, agora direcionada pelo paradigma da fundamentalidade, visa atingir eficazmente essa nova realidade.

Para tanto, faz-se necessária a adoção de uma hermenêutica capaz de assumir, na estrutura clássica do instituto, a função preventiva prospectiva.

Assim, a Responsabilidade Civil Preventiva pode ser operacionalizada, inicialmente, entre a diferença de ilícito (antijuridicidade e imputação) com a ideia de dano (lesão a interesse juridicamente tutelável), o que permite a sua incidência de maneira dinâmica e sistemática, através de tutelas diversificadas, tanto para a prevenção, como para 
a cessação, bem como para a reparação do dano. Além disso, influencia o retorno da culpa objetiva em um novo standard comparativo, e imposição da obrigação de prudência, ou precaução (art. 186, CC), sem olvidar a diversificação do elenco de condutas inadmissíveis, a partir do abuso do direito (art. 187, CC). É possível, ainda, identificar o novo modelo proposto no art. 12 do $\mathrm{CC}$, como uma cláusula geral de responsabilidade civil preventiva.

O dano na Responsabilidade Civil Preventiva pode ser visto: a) como risco intolerável em si mesmo considerado; b) como turbação da paz e causador de ansiedade profunda e desnecessária; c) como despesa de prevenção. Tais danos precedem o dano maior e temido pela vítima, mas de qualquer sorte são evidências para se evitar o dano indesejado e ao mesmo tempo são indenizáveis. O nexo de causalidade, por sua vez, pode ser verificado em diversificados mecanismos de presunção de causalidade.

Os pressupostos da Responsabilidade Civil Preventiva pelo princípio da prevenção são: a) ameaça de lesão ou lesão de execução continuada (fator conhecido pela vítima); b) nexo de causalidade a partir de ação direta ou imediata ou de presunção de liame; c) resultado dano provável no futuro com a eventualidade de danos de turbação, danos de ansiedade e despesas de prevenção. Neste caso, verifica-se: a) função preventiva prospectiva, tanto para a evitabilidade do dano indesejado, como para estancar aquele já em desenvolvimento; b) função reparatória, em caso de prevenção não alcançada.

A seu turno, os pressupostos da Responsabilidade Civil Preventiva, pelo princípio da precaução, são: a) produto ou atividade geradora de incerteza científica; b) nexo causal presumido; c) riscos intoleráveis a direitos difusos ou à equidade intergeracional. Neste caso, observa-se a função preventiva prospectiva no sentido de evitar riscos de grande repercussão à coletividade ou indivíduo.

Remarque-se que, todavia, que a proposta da Responsabilidade Civil Preventiva é pautada em proporcionalidade, bem como em legitimação pelos resultados, a fim de, ao mesmo tempo, evite danos personalíssimos e difusos, sem se descurar do desenvolvimento econômico e social exigentes para toda humanidade.

Não há dúvidas da extrema utilidade da Responsabilidade Civil Preventiva para a sociedade contemporânea. É um modelo de tempo real, mas que projeta suas amplas 
possibilidades para o porvir. Afinal, parafraseando Peter Drucker: "a melhor maneira de prover o futuro é criá-lo". Cria-se, portanto, novo modelo de responsabilidade civil, justamente pelo nosso compromisso solidário com a pessoa e as gerações atuais e futuras. 


\section{BIBLIOGRAFIA}

ABBAGNANO, Nicola. Dicionário de Filosofia. Trad. Alfredo Bosi e Ivone Castilho Benedetti. São Paulo: Martins Fontes, 2007.

ACCIARRI, Hugo A. La relación de causalidad y las funciones del Derecho de Daños: reparación, prevención, minimización de costos sociales. Buenos Aires: AbeledoPerrot, 2009.

ALENCASTRO, Mario Sergio. Hans Jonas e a proposta de uma ética para a civilização tecnológica. Desenvolvimento e meio ambiente, n. 19, p.13-27, jan./jun. 2009.

ALEXY, Robert. Constitucionalismo discursivo. Trad. Luís Afonso Heck. 2. ed. Porto Alegre: Livraria do Advogado Editora, 2008.

Teoria de los derechos fundamentales. Trad. Carlos Bernal Pulido. Madrid: Centro de Estudios Políticos y Constitucionales, 2007.

ALPA, Guido. La responsabilità civile. Parte Generale. Torino: Utet Giuridica, 2010. . La responsabilità civile. Principi. Torino: Utet Giuridica, 2010.

ALSINA, Jorge Bustamante. Teoría general de la responsabilidad civil. Buenos Aires: Abeledo-Perrot, 1997.

ALTERINI, Atilio Anibal. Contornos actuales de la responsabilidade civil. Buenos Aires: Abeledo-Perrot, 1987.

ALVIM, Agostinho. Da inexecução das obrigações e suas consequências. 5 ed. São Paulo: Saraiva, 1980.

AMARAL, Francisco. O Código Civil brasileiro e o problema metodológico de sua realização. Do paradigma da aplicação ao paradigma judicativo-decisório. In: CASTILHO, Ricardo; TARTUCE, Flávio (Coord.). Direito Civil: direito existencial e direito patrimonial. São Paulo: Método, 2006.

Direito Civil: introdução. 3. ed. Rio de Janeiro: Renovar, 2000.

Racionalidade e sistema no direito civil brasileiro. Revista de

Direito Civil, n. 63, p. 45-56, jan. /mar. 1993. 
ANGELIN, Karinne Ansiliero. Dano injusto como pressuposto do dever de indenizar. Dissertação de Mestrado. Faculdade de Direito da Universidade de São Paulo. São Paulo. 2013.

ANUNZIATA, Gaetano. Responsabilità civile e risarcibilità del danno. Padova: CEDAM, 2010.

ARAGÃO, Maria Alexandra de Sousa. O princípio do nível elevado de proteção e a renovação ecológica do direito do ambiente e dos resíduos. Coimbra: Almedina, 2006.

ARENDT, Hannah. Origens do totalitarismo: antissemitismo, imperialismo e totalitarismo. São Paulo: Companhia das Letras, 1989.

ARISTÓTELES. Ética a Nicômaco. Trad. Mário da Gama Kury. Brasília: Ed. Universidade de Brasília, 1992.

ASCENSÃO, José de Oliveira. O fundamento do direito: entre o direito natural e a dignidade da pessoa. Revista da Faculdade de Direito da Universidade de Lisboa. Vol. LII. $n^{\circ} 1$ e 2. p. 29-44. Coimbra: Coimbra Editora, 2011.

São Paulo: Saraiva, 2010.

. Direito civil. Teoria geral. As pessoas. Os bens. Vol. 1.

ATIYAH, Patrick. The dammages lottery. Oxford: Hart Publishing, 1997.

ÁVILA, Humberto. Teoria dos princípios: da definição à aplicação dos princípios jurídicos. São Paulo: Malheiros, 2011.

AYALA, Patrick de Araújo. A proteção jurídica das futuras gerações na sociedade de risco global. In: LEITE, José Rubens Morato; FERREIRA, Heline Sivini; BORATTI, Larissa Verri. Estado de direito ambiental: tendências. 2. Ed. Rio de Janeiro: Forense Universitária, 2010.

AZEVEDO, Antônio Junqueira de. Por uma nova categoria de dano na responsabilidade civil: o dano social. Novos estudos e pareceres de direito privado. São Paulo: Saraiva, 2009.

- Natureza jurídica do contrato de consórcio (sinalagma indireto). Onerosidade excessiva em contrato de consórcio. Resolução parcial do contrato. In: Novos estudos e pareceres de direito privado. São Paulo: Saraiva, 2009.

- Crítica ao personalismo ético da Constituição da República e do Código Civil. In: AZEVEDO, Antônio Junqueira de; Tôrres, Heleno; 
Carbone, Paolo (orgs.). Princípios do novo Código Civil brasileiro e outros temas. Homenagem à Tullio Ascarelli. São Paulo: Quartier Latin, 2008.

- Caracterização jurídica da dignidade da pessoa humana. Estudos e pareceres de Direito Privado. São Paulo: Saraiva, 2004.

O direito como sistema complexo e de $2^{\mathrm{a}}$ ordem. Estudos e parecedes de direito privado. São Paulo: Saraiva, 2004.

. Caracterização jurídica da dignidade da pessoa humana.

Revista dos Tribunais. n. 797. p. 11-26. mar./2002.

BALICKI, Marcelo. A delimitação do Princípio da Precaução e o paradigma complexo de Edgar Morin. Revista de Direito Ambiental, v. 12, n. 48 (out./dez. 2007), p. 140-178. São Paulo: Revista dos Tribunais, 2007.

BARBOSA, Ana Mafalda Castanheira Neves de Miranda. Responsabilidade civil extracontratual: novas perspectivas em matéria de nexo de causalidade. Cascais: Princípia, 2014.

\section{Liberdade vs.}

Responsabilidade: a precaução como fundamento da imputação delitual? Coimbra: Almedina, 2006.

BARCELLONA, Mário. Tratatto della responsabilità civile. Torino: Utet Giuridica, 2011.

BARROSO, Luís Roberto. Neoconstitucionalismo e constitucionalização do direito: o triunfo tardio do direito Constitucional do Brasil. In: SOUZA NETO, Cláudio Pereira de; SARMENTO, Daniel (Coord.). A constitucionalização do direito: fundamentos teóricos e aplicações específicas. Rio de Janeiro: Lumen Juris, 2007.

BAUDRILLARD, Jean. A sociedade de consumo. Lisboa: Edições 70, 2007.

BAUMAN, Zygmunt. Medo líquido. Trad. Carlos Alberto Medeiros. Rio de Janeiro: Jorge Zahar, 2008.

Vida para consumo: a transformação das pessoas em mercadorias. Trad. Carlos Alberto Medeiros. Rio de Janeiro: Jorge Zahar Ed., 2008.

BECK, Ulrich. Sociedade de risco: rumo a uma outra modernidade. São Paulo: Ed. 34, 2010. 
. World at risk. Translated by Ciaran Cronin. Cambridge: Polity Press,

- O que é globalização? Equívocos do globalismo: respostas à globalização. Trad. André Carone. São Paulo: Paz e Terra, 1999.

. Autodissolução e auto-risco da sociedade industrial: o que isso significa? In: BECK, Ulrich; GIDDENS, Anthony, LASH, Scott. Modernização reflexiva: política, tradição e estética na ordem social moderna. Trad. Magda Lopes. São Paulo: Editora da Universidade Estadual Paulista, 1997.

BENACCHIO, Marcelo. A função punitiva da responsabilidade civil no Código Civil. In: LOTUFO, Renan; NANNI, Giovanni Ettore; MARTINS, Fernando Rodrigues (coord.). Temas relevantes do direito civil contemporâneo: reflexões sobre os 10 anos do Código Civil. São Paulo: Atlas, 2012.

BENJAMIN, Antônio Herman V. Responsabilidade civil pelo dano ambiental no direito brasileiro e as lições do direito comparado. Disponível em $<$ http://bdjur.stj.jus.br/xmlui/bitstream/handle/2011/8632/A_Responsabilidade\%20_Civil.p df;jsessionid $=46 \mathrm{ED} 2 \mathrm{C} 19 \mathrm{~A} 1 \mathrm{E} 65 \mathrm{~F} 4744 \mathrm{ACD} 46 \mathrm{CF} 328 \mathrm{~F} 175$ ? sequence $=3>$. Acesso em: 25 set. 2013.

; MARQUES, Claudia Lima; BESSA, Leonardo Roscoe. Manual de direito do consumidor. 2. ed. rev., atual. e ampl. São Paulo: Editora Revista dos Tribunais, 2009.

O princípio do poluidor-pagador e a reparação do dano ambiental. Dano ambiental: prevenção, reparação e repressão. São Paulo: Revista dos Tribunais, 1994.

BERBERI, Marco Antônio Lima. Os princípios na teoria do direito. Rio de Janeiro: Renovar, 2003.

BERGEL, Jean-Louis. Teoria geral do direito. São Paulo: Martins Fontes, 2006.

BEVILÁQUA, Clóvis. Código Civil dos Estados Unidos do Brasil Comentado. v.1. $6^{\mathrm{a}}$ ed. Rio de Janeiro: Francisco Alves, 1940.

BIDART CAMPOS, German J. Las obligaciones en el Derecho Constitucional. Buenos Aires: Ediar, 1987.

BITTAR, Carlos Alberto. Os direitos da personalidade. $7^{\mathrm{a}}$ ed. Rio de Janeiro: Forense Universitária, 2004. 
BLOCH, Cyril. La cessation de l'illicite: recherche sur une fonction méconnue de la responsabilité civile extracontractuelle. Paris: Dalloz, 2008.

BOBBIO, Norberto. Da estrutura à função: novos estudos de teoria do direito. Trad. Daniela Beccaccia Versiani. Barueri: Manole, 2007.

. O positivismo jurídico: lições de filosofia do direito. Trad. Márcio Pugliesi, Edson Bini, Carlos E. Rodrigues. São Paulo: Ícone, 1995.

. Teoria do ordenamento jurídico. $6^{\mathrm{a}}$ ed. Trad. Maria Celeste C. J. Santos. Brasília: Editora Universidade de Brasília, 1995.

. Teoria generale del diritto. Torino: G. Giappichelli Editore, 1993.

BOITEUX, Elza Antônia P.C; BOITEUX, Fernando Netto. Poluição eletromagnética e meio ambiente: o princípio da precaução. Porto Alegre: Sérgio Antônio Fabris editor, 2008 .

BONNECASE, Julien. The Problem of Legal Interpretation in France. Journal of Comparative Legislation and International Law. Third Series, vol. XII, 1930.

BORGES, Roxana Cardoso Brasileiro. Dos direitos da personalidade. In: LOTUFO, Renan; NANNI, Giovanni Ettore (Coord.). Teoria geral do direito civil. São Paulo: Atlas, 2008.

BOUTONNET, Mathilde. Le principe de précaution en droit de la responsabilité civile. Paris: L.G.D.J., 2005.

Bilan et avenir du principe de précaution en droit de la responsabilité civile. Recueil Dalloz no 40, 18 novembre 2010.

BRAGgA NETO, Felipe Peixoto. Teoria dos ilícitos civis. Belo Horizonte: Del Rey, 2003.

BRITTO, Carlos Ayres, O humanismo como categoria constitucional. Belo Horizonte: Fórum, 2007.

BRÜSEKE, Franz Josef. Riesgo y Contingencia. In: VARELLA, Marcelo Dias (Org.). Derecho, sociedad y riegos: la sociedad contemporánea vista através de la idea de riesgo. Brasília: UNICEUB e UNITAR, 2006.

BUSNELLI, Francesco D.; PATTI, Salvatore. Danno e responsabilità civile. Terza 
Edizione. Torino: G. Giappichelli Editore, 2013.

Dott. A. Giuffrè Editore, 1985.

; SCALFI, Gianguido (a cura di). Le pene private. Milano:

CALABRESI, Guido. The costs of accidents: a legal and economic analysis. New Haven : Yale Univ Press, 1970.

CALIXTO, Marcelo Junqueira. A culpa na responsabilidade civil: estrutura e função. Rio de Janeiro: Renovar, 2008.

A Responsabilidade Civil do Fornecedor de Produtos pelos Riscos do Desenvolvimento. Rio de Janeiro: Renovar, 2004.

CALVO COSTA, Carlos A. Daño resarcible. Buenos Aires: Hammurabi, 2005.

CANARIS, Claus-Wilhelm. Pensamento sistemático e conceito de sistema na ciência do direito. Int. e trad. A. Menezes Cordeiro. $3^{\mathrm{a}}$ ed. Lisboa: Fundação Calouste Gulbenkian, 2002 .

CAPELO DE SOUSA, Rabindranath V. A. O direito geral de personalidade. Coimbra: Coimbra Editora, 1995.

Coimbra Editora, 2003.

. Teoria geral do direito civil. Tomo I. Coimbra:

CARNAÚBA, Daniel Amaral. Distribuição de riscos nas relações de consumo: uma análise econômica. In: LOPEZ, Teresa Ancona; LEMOS, Patrícia Faga Iglecias; RODRIGUES JÚNIOR, Otávio Luiz. Sociedade de risco e direito privado: desafios normativos, consumeristas e ambientais. São Paulo: Atlas, 2013.

CARNELUTTI, Francesco. Il danno e il reato. Padova : CEDAM, 1930.

CARVAL, Suzanne. La responsabilité civile dans sa fonction de peine privée. Paris: L.G.D.J, 1995.

CARVALHO, Délton Winter. As mudanças climáticas e a formação do Direito dos Desastres. Revista NEJ - Eletrônica. Vol. 18. n. 3, p.397-415, set-dez 2013.

- Dano ambiental futuro: a responsabilização civil pelo

risco ambiental. Rio de Janeiro: Forense Universitária, 2008. 
CASTANHEIRA NEVES, António. O direito hoje e com que sentido? $2^{\mathrm{a}}$ ed. Lisboa: Instituto Piaget, 2011.

. Entre o legislador a sociedade e o juiz ou entre sistema função e problema - os modelos actualmente alternativos da realização jurisdicional do direito. Boletim da Faculdade de Direito. V. LXXIV. Coimbra: Coimbra Editora, 1998.

Coimbra: Coimbra Editora, 1993.

Metodologia jurídica: problemas fundamentais.

CASTELLS, Manuel. A sociedade em rede. Vol. 1. $2^{\mathrm{a}}$ ed. Trad. Roneide Venancio Majer e Klauss Brandini Gerhardt. São Paulo: Paz e Terra, 1999.

CASTRO, Torquato. Teoria da situação jurídica em direito privado nacional: estrutura, causa e título legitimatário do sujeito. São Paulo: Saraiva, 1985.

CASTRONOVO, Carlo. La nuova responsabilità civile. Milano: Dott. A. Giuffrè Editore, 2006.

CAVAliERI FILHO, Sérgio. Programa de responsabilidade civil. $8^{a}$ ed. São Paulo: Atlas, 2008.

2009.

. Programa de direito do consumidor. São Paulo: Atlas,

CODERCH, Pablo Salvador. Daños tardíos Avite c. Grünenthal. Comentario a la SJPI n ${ }^{\circ}$ 90 Madrid, 19.11.2013, sobre los daños causados por la talidomida. InDret. Revista para el análisis del derecho. Disponível em: $<\underline{w w w . i n d r e t . c o m}>$. Acesso em: 05 jan./2014.

CONSEIL EUROPÉEN. Reunión de Nice. 7-9 déc 2000. Annexe III. Résolution sur le Principe de Précaution. Disponível em $<$ http://www.europarl.europa.eu/summits/nice2_fr.htm>. Acesso em: 25 set. 2013.

COSTA JÚNIOR, Paulo José da. Nexo causal. 4. ed. rev. e atual. São Paulo: Revista dos Tribunais, 2007.

COSTA, Carlos A. Calvo. Dano resarcible. Buenos Aires: Hammurabi, 2005.

COSTA, Mario Júlio Almeida. Direito das obrigações. 7. ed. rev. e atual. Coimbra: Almedina, 1999. 
COVIELLO, Nicolas. Doctrina general del derecho civil. $4^{\mathrm{a}}$ ed. Buenos Aires: Librería El Foro, 2003.

CREMASCO, Suzana Santi. A distribuição dinâmica do ônus da prova. Rio de Janeiro: GZ, 2009.

DE CUPIS, Adriano. Il danno: teoria generale della responsabilità civile. Vol. I. Milano: Dott. A. Giuffrè Editore, 1966.

. Os direitos da personalidade. Trad. Antônio Vera Jardim e António Miguel Caeeiro. Lisboa: Morais Editora, 1961.

DEL VECCHIO, Giorgio. Evoluzione ed involuzione del Diritto. $3^{\text {a }}$ ed. Roma: Studium Urbis, 1945.

DIAS, José de Aguiar. Da responsabilidade civil. Rio de Janeiro: Renovar, 2006.

DIAS, Lúcia Ancona Lopez de Magalhães. Publicidade e direito. São Paulo: Editora Revista dos Tribunais, 2010.

DÍEZ-PICAZO, Luis. Fundamentos del derecho civil patrimonial V: la responsabilidade civil extracontratual. Pamplona: Civitas-Thomson Reuters, 2011.

DONNINI, Rogério. Prevenção de danos e a extensão do princípio neminem laedere. In: NERY, Rosa Maria de Andrade e DONNINI, Rogério (Organizadores). Responsabilidade Civil: estudos em homenagem ao Professor Rui Geraldo Camargo Viana. São Paulo: Editora Revista dos Tribunais, 2009.

DOUGLAS, Mary; WILDAVSKY, Aaron. Risk and culture: an essay on the selection of technological and environmental dangers. Berkeley: University of California Press, 1982.

DURKHEIM, Émile. Leçons de sociologie - Pshysique des moeurs et du Droit. Paris: PUF, 1950.

ENGISCH, Karl. Introdução ao pensamento jurídico. Trad. J. Baptista Machado. Lisboa: Fundação Calouste Gulbenkian, 2001.

EUROPEAN GROUP ON TORT LAW. Princípios de Direito Europeu da Responsabilidade Civil. Disponível em: <http://civil.udg.edu/php//index.php?id=129>. Acesso em: 11 out./2013.

FABIAN, Christoph. O dever de informar no direito civil. São Paulo: Editora Revista dos Tribunais, 2002. 
FALCÓN y TELLA, Maria José. Lições de teoria geral do direito. Trad. Cláudia de Miranda Avena, Ernani de Paula Contipelli. São Paulo: Revista dos Tribunais, 2011.

FARIA, José Eduardo. Direito e conjuntura. 2. ed. São Paulo: Saraiva, 2010.

(Org.). A crise do Direito numa sociedade em mudança. Brasília: Ed. Universidade de Brasília, 1988.

FERNANDES, Wanderley. Cláusulas de exoneração e de limitação de responsabilidade. São Paulo: Saraiva, 2013.

FERRAJOLI, Luigi. Por uma carta dos bens fundamentais. Trad. Daniela Cademartori e Sergio Cademartori. Sequência, nº 60, p. 29-73, jul. 2010.

FERRARI, Vicenzo. La funzione di garantia nella responsabilità civile. Napoli: Edizioni Scientifique Italiane, 2005.

FERRAZ JÚNIOR, Tércio Sampaio. A ciência do direito. São Paulo: Atlas, 1980.

FERREIRA, Ana Elisabete. A vulnerabilidade humana e a pessoa para o direito breves notas. In: Revista do Instituto de Direito Brasileiro. n. 2. p.1032. Lisboa: Faculdade de Direito da Universidade de Lisboa, 2014.

FERREIRA, Keila Pacheco. Abuso do direito nas relações obrigacionais. Belo Horizonte: Del Rey, 2007.

FLORES FILHO, Edgar Gastón Jacobs; RIBEIRO, Rita de Cássia. Racionalidade Limitada do Consumidor e Assimetria de Informação. Economic A Enalysis of Law Review. V. 3, nº 1, p.109-121, Jan-Jun, 2012.

FLUMignAN, Silvano José Gomes. Dano-evento e dano-prejuízo. Dissertação. Faculdade de Direito da Universidade de São Paulo. 2009.

FOSTER, Caroline E. Science and the Precautionary Principle in International Courts and Tribunals: expert evidence, burden of proof and finality. Cambridge: Cambridge University Press, 2011.

FRADA, Manuel António de Castro Portugal Carneiro da. Teoria da confiança e responsabilidade civil. Coimbra: Almedina, 2004.

. Contrato e deveres de proteção. Separata do volume XXXVIII do Suplemento ao Boletim da Faculdade de Direito da Universidade de Coimbra. Coimbra: Gráfica de Coimbra, 1994. 
FRANÇA, Rubens Limongi. As raízes da responsabilidade aquiliana. In: NERY Jr., Nelson; NERY, Rosa Maria Andrade (Org.). Doutrinas Essenciais Responsabilidade Civil. Volume I. Teoria Geral. São Paulo: Editora Revista dos Tribunais, 2010.

FRAZÃO, Ana. Principais distinções e aproximações da responsabilidade civil nos modelos francês, alemão e anglo-saxão. In: RODRIGUES JÚNIOR, Otávio Luiz; MAMEDE, Gladston; ROCHA, Maria Vital da. Responsabilidade civil contemporânea. São Paulo: Atlas, 2011.

FRIEDMAN, Meyer; FRIEDLAND, Geral W. As dez maiores descobertas da medicina. Trad.

José Rubens Siqueira. São Paulo: Companhia de Bolso, 2006.

GAILLARD, Émilie. Générations futures et droit privé: vers un droit des generations futures. Paris: L.G.D.J, 2011.

GALLO, Paolo. Introduzione alla responsabilità civile: articole 2043/2059 C.C. Torino: G. Giappichelli Editore, 2000. 1996. Pene private e responsabilità civile. Milano: Dott. A. Giuffrè Editore,

GALVÃO TELLES, Inocêncio. Introdução ao estudo do direito. v.2. Coimbra: Coimbra ed., 2001.

GARCIA, Maria da Glória F.P.D. O lugar do direito na proteção do ambiente. Coimbra: Almedina, 2007.

GHERSI, Carlos Alberto. Reparación de daños. Buenos Aires: Editorial Universidad, 1989.

GIDDENS, Anthony. As consequências da modernidade. São Paulo: editora UNESP, 1991.

GIERKE, Otton. La función del derecho privado: la natureza de las asociaciones privadas. Trad. José M. Navarro Palencia. Madrid: Sociedad Editorial Española, 1904.

GILISSEN, John. Introdução histórica ao Direito. Trad. A.M.Hespanha e L.M.Macaísta Malheiros. $2^{\mathrm{a}}$ ed. Lisboa: Fundação Calouste Gulbenkian, 1995.

GIORGI, Rafaelle de. Direito, democracia e risco: vínculos com o futuro. Porto Alegre: Sérgio Antônio Fabris Editor, 1998. 
GODARD, Olivier. The precautionary principle and chemical risks. Ecole Polytechnique. Centre National de la Recherche Scientifique. April/2012. Disponível em: http://< http://hal.archives-ouvertes.fr/docs/00/68/97/61/PDF/cahier_de_recherche_201217.pdf. $>$. Acesso em: 26 set./2013.

Le principe de précaution comme norme de l'action publique, ou la proportionnalité en question. Revue économique. Vol. 54, Nº 6, p.1245-1276, novembre 2003.

GODOY, Cláudio Luiz Bueno de. Responsabilidade civil pelo risco da atividade. São Paulo: Saraiva, 2009.

Código civil comentado: doutrina e jurisprudência: Lei 10.406/02. Cézar Peluso (Coord.). São Paulo: Manole, 2008.

GOMES, Carla Amado. Risco e modificação do acto autorizativo concretizador de deveres de proteção do ambiente. Lisboa: Edição da autora, 2012.

GOMES, Orlando. Introdução ao direito civil. 10a ed. Rio de Janeiro: Forense, 1988.

GRAU, Eros Roberto. O direito posto e o direito pressuposto. São Paulo: Malheiros, 2005.

GRIMM, Dieter. A função protetiva do Estado. In: SOUZA NETO, Cláudio Pereira de; SARMENTO, Daniel (Coord.). A constitucionalização do direito: fundamentos teóricos e aplicações específicas. Rio de Janeiro: Lumen Juris, 2007.

GRISON, Denis. Vers une philosophie de la precaution. Paris: L'Harmattan, 2009.

HARBELE, Peter. Estado constitucional cooperativo. Trad. Marcos Augusto Maliska e Elisete Antoniuk. Rio de Janeiro: Renovar, 2007.

HARTMANN, Ivar Alberto Martins. O princípio da precaução e sua aplicação no direito do consumidor: o dever de informação. Revista de direito do consumidor. Vol. 70. AbrilJunho 2009. São Paulo: Revista dos Tribunais, 2009.

HATTENHAUER, Hans. Los fundamentos histórico-ideológicos del Derecho Aleman: entre la jerarquia y la democracia. Trad. Miguel Izquierdo Macias-Picavea. Madrid: Editorial Revista de Derecho Privado, 1981.

HEGEL, George Wilhelm Friedrich, A razão na história: uma introdução geral à filosofia da história. Trad. Beatriz Sidou. $2^{\circ}$ ed. São Paulo: Centauro, 2001. 
HELZEL, Paola B. La nozione di responsabilità baricentro tra etica, diritto e politica. In: CALABRÓ, Gian Pietro (a cura di). La nozione di responsabilità tra teoria e prassi. Milano: CEDAM, 2010.

HERRERA, Edgardo López. La función preventiva de la responsabilidad civil y su relación con las otras funciones. Revista de derecho de daños 2008-2: prevención del dano. Dirigido por Jorge Mosset Iturraspe y Ricardo Luis Lorenzetti. Santa Fe: RubinzalCulzoni, 2008.

HIRONAKA, Giselda Maria Fernandes. Responsabilidade pressuposta. Belo Horizonte: Del Rey, 2005.

HOBSBAWM, Eric J. Age of extremes: the short twentieth century 1914-1991. London: Abacus, 1995.

HOFMEISTER, Maria Alice Costa. O dano pessoal na sociedade de risco. Rio de Janeiro: Renovar, 2002.

HORKHEIMER, Max. Eclipse da Razão. Rio de Janeiro: Labor do Brasil, 1976.

IHERING, Rudolph Von. Culpa in contrahendo. Ou indemnização em contratos nulos ou não chegados à perfeição Trad. Paulo Cardoso C. Mota Pinto. Coimbra: Almedina, 2008.

ITURRASPE, Jorge Mosset; PIEDECASAS, Miguel A. Responsabilidad por daños: actualización doctrinaria y jurisprudencial de los tomos I a X. Tomo XI. Santa Fe: Runbinzal-Culzoni, 2009.

Rubinzal-Culzoni, 1994.

. Interpretación económica del contrato. Santa Fé:

JAYME, Erik. Identité culturelle et intégration: le droit international privé postmoderne. Collected Courses of the Hague Academy of International Law 251. The Hague/Boston/London: Martinus Nijhoff Publishers, 1995.

JELLINEK, George. Sistema dei diritti pubblici subbiettivi. Trad. G. Vitagliano. Milano: Società Editrice Libraria, 1912.

JONAS, Hans. O princípio responsabilidade: ensaio de uma ética para a civilização ecológica. Rio de Janeiro: Contraponto, Puc Rio, 2006.

JOSSERAND, Louis. Évolution e actualités: conferénces de droit civil. Paris: Recueil Sirey, 1936. 
Dalloz, 1927.

JOURDAIN, Patrice. Les principes de la responsabilitè civile. Paris: Dalloz, 2000.

- Les anciens salariés qui perçoivent l'allocation de préretraite amiante (ACAATA) peuvent-ils solliciter la réparation de leus pertes de revenus? Revue Trimestrielle de Droit Civile. Juillet/Septembre. 2010. Paris. Dalloz. 2010

. Responsabilité civile. Revue Trimestrielle de Droit Civile. Octobre/decembre 2008. No 4. Paris. Dalloz. 2008.

KANT, Immanuel. Fundamentação da metafísica dos costumes. Trad. Paulo Quintela. São Paulo: Abril Cultural, 1980.

KAUFMANN, Arthur. Filosofia do direito, teoria do direito, dogmática jurídica. In: KAUFMANN, Arthur; HASSEMER, Winfried. Introdução à filosofia do direito e à teoria do direito contemporâneas. Trad. Marcos Keel. Lisboa: Fundação Calouste Gulbekian, 2002.

KELSEN, Hans. Teoria pura do direito. Trad. João Batista Machado. $4^{\mathrm{a}}$ ed. São Paulo: Martins Fontes, 1994.

KERN, Bernd-Rüdiger. A função de satisfação na indenização do dano pessoal: um elemento penal para a satisfação do dano? Revista de direito do consumidor. Vol. 33. São Paulo: Revista dos Tribunais, 2000.

KUHN, Thomas S. A estrutura das revoluções científicas. $5^{\mathrm{a}}$ ed. São Paulo: Perspectiva, 2000 .

LAFER, Celso. A reconstrução dos direitos humanos: um diálogo com o pensamento de Hannah Arendt. São Paulo: 4ª reimpressão. Companhia das Letras, 2001.

LALOU, Henri. Traité pratique de la responsabilité civile. Quatrième édition. Paris: Dalloz, 1949.

LAMBERT-FAIVRE, Yvonne. L'éthique de la responsabilité. Revue Trimestrielle de Droit Civil. Paris. v.97. n.1.janv./mar. 1998.

L'evolution de la responsabilité civile d'une dette de responsabilité à une créance d'indemnisation. Revue Trimestrielle de Droit Civil. Paris. v.86. n.1. p.1-20. jan./mar. 1987.

LARENZ, Karl. Metodologia da ciência do direito. Trad. José Lamego. 3 ed. Lisboa: Fundação Calouste Gulbenkian, 1997. 
. Derecho justo: fundamentos de etica juridica. Traducción y presentación Luis Díez-Picazo. Madrid: Editorial Civitas, 1991.

. Derecho civil: parte general. Trad. e notas de Miguel Izquierdo y Macías-Picavea. Madrid: Revista de Derecho Privado, 1978.

. Derecho de obligaciones. Trad. Jaime Santos Briz. Madrid: Revista de Derecho Privado, 1958.

LASCOUMES, Pierre. La précaution, un nouveau standard de jugement. Revue Esprit. Novembre $1997 . \quad$ Disponível em $<$ http://www.esprit.presse.fr/archive/review/article.php? code $=10371 \&$ folder $=2>$. Acesso: 01 set. 2013.

LEITE, José Rubens Morato; AYALA, Patryck de Araújo. Dano ambiental: do individual ao coletivo extrapatrimonial. 4a ed. São Paulo: RT, 2011.

; MELO, Melissa Ely. As funções preventivas e precaucionais da responsabilidade civil por danos ambientais. Revista Sequência, $\mathrm{n}^{\mathrm{o}}$ 55, p.195-218, dez. 2007.

LEMOS, Patrícia Faga Iglecias. Resíduos sólidos e responsabilidade civil pós-consumo. São Paulo: Editora Revista dos Tribunais, 2011.

LEMOS, Patrícia Faga Iglecias. Direito ambiental: responsabilidade civil e proteção ao meio ambiente. 3. ed. rev., atual. e ampl. São Paulo: Editora Revista dos Tribunais, 2010.

LEMOS, Patrícia Iglecias Faga. Mudanças climáticas e responsabilidade civil por dano ao meio ambiente. In: LAVRATTI, Paula Lavratti; PRESTES, Vanêsca Buzelato. Direito e mudanças climáticas [recurso eletrônico]. São Paulo : Instituto O Direito por um Planeta Verde, 2010.

LEVINAS, Emmanuel. Totalidade e Infinito, Coimbra: Edições 70, 2008.

LEVY, Daniel Andrade. Responsabilidade civil: de um Direito dos Danos a um Direito das Condutas Lesivas. São Paulo: Atlas, 2012.

LEVY, Daniel de Andrade. Uma visão cultural dos punitive damages. Revista de Direito Privado. Vol. 45. Ano 12. Janeiro-Março 2011. São Paulo: Revista dos Tribunais, 2011.

LIMA, Alvino. Culpa e Risco. $2^{\text {a }}$ ed. rev. e atual. por Ovídio Rocha Barros Sandoval. São Paulo: Editora Revista dos Tribunais, 1999. 
LIPOVETSKY, Gilles. A felicidade paradoxal: ensaio sobre a sociedade de hiperconsumo. Trad. Maria Lúcia Machado. São Paulo: Companhia das Letras, 2007.

LOMBARDI, Giorgio. I doveri costituzionali: alcune osservazioni. In: R. Balduzzi, M. Cavino, E. Grosso e J. Luther (Coord.). I doveri costituzionali: la prospettiva del giudice delle legge. Torino: G. Giappichelli, 2007.

LÓPEZ CABANA, Roberto M. Responsabilidad civil por acidentes. Buenos Aires: Abeledo-Perrot, 1998.

LOPEZ, Teresa Ancona. Responsabilidade civil na sociedade de risco. In: LOPEZ, Teresa Ancona; LEMOS, Patrícia Faga Iglecias; RODRIGUES JÚNIOR, Otávio Luiz (Coord). Sociedade de risco e direito privado. São Paulo: Atlas, 2013.

A presunção no Direito, especialmente no Direito Civil. In: STOCO, Rui; MENDES, Gilmar Ferreira. Doutrinas Essenciais de Direito Civil. Vol. 5. São Paulo: Editora Revista dos Tribunais, 2014.

Civil. São Paulo: Quartier Latin, 2010.

- Princípio da Precaução e Evolução da Responsabilidade Nexo causal e produtos potencialmente nocivos: a experiência brasileira do tabaco. São Paulo: Quartier Latin, 2008.

- Principais linhas da responsabilidade no direito brasileiro contemporâneo. In: AZEVEDO, Antônio Junqueira de; TÔRRES, Heleno Taveira; CARBONE, Paolo. Princípios do novo Código Civil brasileiro e outros temas. Homenagem a Tullio Ascarelli. São Paulo: Quartier Latin, 2008.

LORENZETTI, Ricardo Luis. Teoria da decisão judicial: fundamentos de direito. Trad. Bruno Miragem. Notas Cláudia Lima Marques. São Paulo: Editora Revista dos Tribunais, 2010.

Teoria geral do direito ambiental. Trad. Fábio Costa Morosini e Fernanda Nunes Barbosa. São Paulo: RT, 2010.

. Teoría general del contrato y de los servicios: una teoría sistémica del contrato. Contratos de servicios a los consumidores. Santa Fe: RubinzalCulzoni, 2005.

Tribunais, 1998.

. Fundamentos do direito privado. São Paulo: Revista dos

LOSANO, Mario G. Sistema e estrutura no direito. Volume: 2. O século XX. Trad. Luca 
Lamberti. São Paulo: Martins Fontes, 2010.

LOTUFO, Renan. A responsabilidade civil e o papel do juiz no Código Civil de 2002. In: NERY, Rosa Maria de Andrade; DONNINI, Rogério (Organizadores). Responsabilidade Civil: estudos em homenagem ao Professor Rui Geraldo Camargo Viana. São Paulo: Editora Revista dos Tribunais, 2009.

. Da oportunidade da codificação civil e a Constituição. In: SARLET, Ingo Wolfgang (Org.). O novo Código Civil e a Constituição. Porto Alegre: Livraria do Advogado, 2003.

LOURENÇO, Paula Meira. A função punitiva da responsabilidade civil. Coimbra: Coimbra Editora, 2006.

LUHMANN, Niklas. Risk: a sociological theory. Translated by Rhodes Barret. Berlin: Walter de Gruyter, 1993.

. Legitimação pelo procedimento. Brasília. UNB, 1980.

LUPTON, Deborah. Risk and sociocultural theory: new directions and perspectives. Cambridge: Cambridge University Press, 1999.

LYOTARD, Jean-François. O pós-moderno. $3^{\text {a }}$ ed. Trad. Ricardo Corrêa Barbosa. Rio de Janeiro: José Olympio Editora, 1998.

MARINONI, Luiz Guilherme. Tutela inibitória: individual e coletiva. $5^{\text {a }}$ ed. São Paulo: Revista dos Tribunais, 2012.

Paulo: RT, 2010. Técnica processual e tutela dos direitos. $3^{\mathrm{a}}$ ed. São ; ARENHART, Sergio Cruz. Curso de Processo Civil. v. 2. 6. ed. São Paulo: Revista dos Tribunais, 2007.

MARINS, James. Responsabilidade da empresa pelo fato do produto. São Paulo: Editora Revista dos Tribunais, 1993.

MARKESINIS, Basil; DEAKIN, Simon; ANGUS, Johnston. Tort Law. Seventh edition. Oxford: Oxford University Press, 2013.

MARQUES, Cláudia Lima; MIRAGEM, Bruno. O novo direito privado e a proteção dos vulneráveis. São Paulo: Editora Revista dos Tribunais, 2012. 
. O "diálogo das fontes" como método da nova teoria geral do direito: um tributo a Erik Jayme. In: MARQUES, Cláudia Lima (Coord). Diálogo das fontes: do conflito à coordenação de normas do direito brasileiro. São Paulo: Editora Revista dos Tribunais, 2012.

; BENJAMIN, Antônio Herman V.; BESSA, Leonardo Roscoe. Manual de direito do consumidor. São Paulo: Editora Revista dos Tribunais, 2007.

; BENJAMIN, Antônio Herman V.; MIRAGEM, Bruno. Comentários ao Código de Defesa do Consumidor. 2. ed. rev., atual. e ampl. São Paulo: Editora Revista dos Tribunais, 2006.

. Organismos geneticamente modificados, informação e risco da "novel food": o direito do consumidor desarticulado? Cadernos doPrograma de PósGraduação em Direito. Vol. III, nº VI. Porto Alegre: PPGDir./URFGS, 2005.

MARTINS, Fernando Rodrigues. Princípio da Justiça Contratual. São Paulo: Saraiva, 2011.

MARTINS-COSTA, Judith. Contratos. Conceito e evolução. In: LOTUFO, Renan; NANNI, Giovanni Ettore (Coord.). Teoria geral dos contratos. São Paulo: Atlas, 2011.

Comentários ao novo Código Civil. Do inadimplemento das obrigações. Vol. V. Tomo II. $2^{\text {a }}$ edição. Rio de Janeiro: Forense, 2009.

- Os campos normativos da boa-fé objetiva: as três perspectivas do direito brasileiro. In: JUNQUEIRA DE AZEVEDO, Antonio; TÔRRES, Heleno Taveira; CARBONE, Paolo (coord). Princípios do Novo Código Civil Brasileiro e Outros Temas: homenagem a Tullio Ascarelli. São Paulo: Quartier Latin, 2008.

O novo Código Civil brasileiro: em busca da "ética da situação". In: BRANCO, Gerson Luiz Carlos; MARTINS-COSTA, Judith. Diretrizes teóricas do novo Código Civil brasileiro. São Paulo, Saraiva, 2002.

; PARGENDLER, Mariana Souza. Usos e abusos da função punitiva (punitive damages e o direito brasileiro). Disponível em $<$ http:// www2.cjf.jus.br/ojs2/index.php/revcej/article/viewArticle/643>. Acesso: 15 jul. 2013.

MARZAGÃO, Nelcina C. de O. Tropardi. Da informação e dos efeitos do excesso de informação no Direito do Consumidor. Tese. Doutorado. Faculade de Direito da Universidade de São Paulo. São Paulo, 2005.

MASI, Domenico de. A sociedade pós-industrial. 4. ed. Trad. Anna Maria Capovilla. São Paulo: Senac, 2003. 
MAZEAUD, Henri; MAZEAUD, León; MAZEAUD, Jean; CHABAS, François. Derecho civil. Obligaciones. Tomo II. Traducción de Luis Andorno. Buenos Aires: Zavalia, 2006.

MEIRELLES, Jussara Maria Leal de. Economia, patrimônio e dignidade do pródigo: mais um distanciamento entre o ser e o ter? In: TEPEDINO, Gustavo; FACHIN, Luiz Edson (Coord.). O direito e o tempo: embates jurídicos e utopias contemporâneas. Estudos em homenagem ao Professor Ricardo Pereira Lira. Rio de Janeiro: Renovar, 2008.

MELO, Diogo L. Machado de. Culpa extracontratual: uma visita, dez anos depois. In: LOTUFO, Renan; NANNI, Giovanni Ettore; MARTINS, Fernando Rodrigues. Temas relevantes do direito civil contemporâneo: reflexões sobre os 10 anos do Código Civil. São Paulo: Atlas, 2012.

MENDONÇA, Diogo Naves. O dano e a sua quantificação: perspectivas de direito e economia. Dissertação de Mestrado. Faculdade de Direito. Universidade de São Paulo. São Paulo. 2012.

MENEZES CORDEIRO, António. Tratado de Direito Civil V. Parte Geral. Exercício Jurídico. Coimbra: Almedina, 2011.

obrigações. Tomo III. $3^{\text {a }}$ ed. Coimbra: Almedina, 2010.

Tratado de Direito Civil Português. Direito das Tratado de direito civil português. Vol. II. Direito das obrigações. t. 1. Coimbra: Almedina, 2009.

Tomo I. Coimbra: Almedina, 2007.

. Tratado de direito civil português. Parte geral. Da boa-fé no direito civil Coimbra: Almedina, 2001.

MIRAGEM, Bruno. Direito do consumidor. São Paulo: Editora Revista dos Tribunais, 2008.

MORAES, Maria Celina Bodin de. Risco, solidariedade e responsabilidade objetiva. In: TEPEDINO, Gustavo; FACHIN, Luiz Edson (coord.). O direito e o tempo: embates jurídicos e utopias contemporâneas. Rio de Janeiro, Renovar, 2008.

- Danos à pessoa humana: uma leitura civilconstitucional por danos morais. Rio de Janeiro: Renovar, 2003.

O Princípio da Solidariedade. Disponível em: $<$ http://www.idcivil.com.br/pdf/biblioteca9.pdf $>$. Acesso em: 18 jul./2013. 
MORIN, Edgar. O método 6: ética. Trad. Juremir Machado da Silva. Porto Alegre: Sulina, 2007.

. Complexidade e ética da solidariedade. In: CASTRO, Gustavo de; CARVALHO, Edgard de Assis; ALMEIDA, Maria da Conceição de. Ensaios de complexidade. $4^{\mathrm{a}}$ ed. Porto Alegre: Sulina, 2006.

Ciência com consciência. $8^{\mathrm{a}}$ ed. Trad. Maria D. Alexandre e Maria Alice Sampaio Dória. Rio de Janeiro: Bertrand, 2005.

Os sete saberes necessários à educação do futuro. $2^{\mathrm{a}}$ ed. Trad. Catarina Eleonora F. da Silva e Jeanne Sawaya. São Paulo: Cortez; Brasília, DF : UNESCO, 2000.

MORSELLO, Marco Fábio. A responsabilidade civil e a socialização dos riscos. Revista da Escola Paulista da Magistratura, Ano 7. N. 2. Jul/Dez. 2006.

MOSSET ITURRASPE, Jorge; PIEDECASAS, Miguel A. Responsabilidad por daños. Tomo XI. Santa Fe: Rubinzal-Culzoni, 2009.

MOTA PINTO, Carlos Alberto da. Teoria geral do direito civil. $4^{\mathrm{a}}$ ed. António Pinto Monteiro e Paulo Mota Pinto (atual.). Coimbra: Coimbra Editora, 2005.

MULHOLLAND, Caitlin Sampaio. A responsabilidade civil por presunção de causalidade. Rio de Janeiro: GZ, 2010.

NABAIS, José Casalta. O dever fundamental de pagar impostos: contributo para a compreensão constitucional do Estado fiscal contemporâneo. Coimbra: Almedina, 2009.

NERY JÚNIOR, Nélson. Rotulagem dos alimentos geneticamente modificados. Biotecnologia no Brasil: uma abordagem jurídica. São Paulo: ABIA, 2002.

NERY, Rosa Maria de Andrade. Introdução ao pensamento jurídico e à teoria geral do Direito Privado. São Paulo: Editora Revista dos Tribunais, 2008.

NETO, João Pedro Gebran. A aplicação imediata dos direitos e garantias fundamentais: a busca de uma exegese emancipatória. São Paulo: Editora Revista dos Tribunais, 2002.

NICOLA, Ubaldo. Antologia ilustrada de filosofia: das origens à idade moderna. Trad. Maria Margherita De Lucca. São Paulo: Globo, 2005.

NINO, Carlos Santiago. Consideraciones sobre dogmática jurídica. México: Unam, 
1974.

NOIVILLE, Christine. Ciência, decisão e ação: três observações em torno do princípio da precaução. VARELLA, Marcelo Dias (Org.). Governo dos riscos. Brasília: UNICEUB e UNITAR, 2005.

Du bon gouvernement des risques: le droit et la question du "risque acceptable". Paris: Presses Universitaires de France, 2003.

NONET, Philippe; SELZNICK Philip. Direito e sociedade: a transição ao sistema jurídico responsivo. Trad. Vera Ribeiro. Rio de Janeiro: Revan, 2010.

NORONHA, Fernando. Direitos das obrigações. v.1. 2a ed. São Paulo: Saraiva, 2007.

OLIVEIRA, Ana Perestrelo de. Causalidade e imputação na Responsabilidade Civil Ambiental. Coimbra: Almedina, 2007.

ORGAZ, Alfredo. Las personas humanas: esencia y existência. Buenos Aires: Hammurabi, 2000.

OST, François. A natureza à margem da lei: a ecologia à prova do direito. Lisboa: Instituto Piaget, 1995.

PATTI, Salvatore. Codice civile tedesco. Milano: Giuffrè, 2005.

PERLINGIERI, Pietro. O direito civil na legalidade constitucional. Trad. Maria Cristina De Cicco. Rio de Janeiro: Renovar, 2008.

; FEMIA, Pasquale. Nozioni introduttive e principi fondamentali del diritto civile. $2^{\mathrm{a}}$ ed. Napoli: Edizione Scientifiche italiane, 2004.

POMBO, Eugenio Llamas. Prevención y reparación: las dos caras del derecho de daños. In: MARTÍNES, Juan Antonio Moreno (Coord.). La responsabilidad civil y su problemática actual. Madrid: Dykinson, 2007.

PONTES DE MIRANDA, Francisco Cavalcanti. Tratado da ação rescisória. Campinas: Bookseller, 1998.

Rio de Janeiro: Bosch, 1972. . Tratado de direito privado. t. IV. $3^{\circ}$ ed.

POSNER, Richard A. El análisis económico del derecho. Trad. Eduardo L. Suárez. México: Fondo de Cultura Económica, 1998. 
PRIEUR, Michel. Le Principe de Précaution. Disponível em $<$ http://www.legiscompare.fr/site-web/IMG/pdf/2-Prieur.pdf $>$. Acesso em: 20 set. 2013.

PRIGOGINE, Ilya. O fim das certezas. Trad. Roberto Leal Ferreira. São Paulo: Editora da Universidade Estadual Paulista, 1996.

Carta para as futuras gerações. Disponível em: http://www1.folha.uol.com.br/fsp/mais/fs3001200004.htm. Acesso em: 18 setembro 2013.

QUÉZEL-AMBRUNAZ, Christophe. Essai sur la causalité em droit de la responsabilité civile. Paris: Dalloz, 2010.

RADBRUCH, Gustav. Arbitrariedad legal y derecho supralegal. Buenos Aires: Abeledo-Perrot, 1962.

RANDALL, Alan. Risk and precaution. Cambridge: Cambridge University Press, 2011.

REALE, Miguel. Direito e planificação. In: CLÈVE, Clèmerson Merlin; BARROSO, Luís Roberto (Coord). Doutrinas essenciais de direito constitucional. v. 6. São Paulo: Revista dos Tribunais, 2011.

São Paulo: Saraiva, 1994.

Fontes e modelos do direito: para um novo paradigma hermenêutico.

Teoria Tridimensional do Direito. São Paulo: Saraiva, 1994.

GOUT, Olivier; BRUN, Philippe Brun. Responsabilité civile. Recueil Dalloz. Janvier 2011. Paris: Editions Dalloz, 2011.

RICOEUR, Paul. O justo ou a essência da justiça. Trad. Vasco Casimiro. Lisboa: Instituto Piaget, 1995.

RODOTÀ, Stefano. A vida na sociedade de vigilância: a privacidade hoje. Trad. Danilo Doneda e Luciana Cabral Doneda. Organização, seleção e apresentação Maria Celina Bodin de Moraes. Rio de Janeiro: Renovar, 2008.

ROSENVALD, Nelson. As funções da responsabilidade civil: a reparação e a pena civil. São Paulo: Atlas, 2013.

RUZIK, Carlos Eduardo Pianovski. Liberdade(s) e função: contribuição crítica para uma nova fundamentação da dimensão funcional do Direito Civil brasileiro. Tese de Doutorado. Universidade Federal do Paraná. Curitiba. 2009. Disponível em: 
http://dspace.c3sl.ufpr.br/dspace/bitstream/handle/1884/19174/Carlos_Eduardo_Tese_com pleta\%5B1\%5D.pdf?sequence=1. Acesso: 09 set. 2013.

SADELEER, Nicolas de. O Estatuto do Princípio da Precaução no Direito Internacional. In: VARELlA, Marcelo Dias; PLATIAU, Ana Flávia Barros (Org.). Princípio da precaução. Belo Horizonte: Del Rey, 2004.

Les principes du pollueur-payeur, de prévention et de précaution: essai sur la genèse et la portée juridique de quelques príncipes du droit de l'environnement. Bruxelles: Bruylant, 1999.

SALVI, Cesare. La responsabilità civile. Milano: Dott. A. Giuffrè Editore, 2005.

SANSEVERINO, Paulo de Tarso Vieira. Princípio da reparação integral: indenização no Código Civil. São Paulo: Saraiva, 2010.

- Responsabilidade civil no Código de Defesa do Consumidor e a defesa do fornecedor. $3^{\text {a }}$ ed. São Paulo: Saraiva, 2010.

SANTOS, Boaventura de Sousa. Para um novo senso comum: a ciência, o direito e a política na transição paradigmática. Vol. 1. A crítica da razão indolente: contra o desperdício da experiência. 4. ed. São Paulo: Cortez, 2002.

SARLET, Ingo Wolfgand; FENSTERSEIFER, Tiago. Deveres fundamentais ambientais: a natureza de direito-dever da norma jusfundamental ambiental. Revista de Direito Ambiental. Ano 17. Vol. 67. p. 11-70. Jul.set. / 2012.

; MARINONI, Luiz Guilherme; MITIDIERO, Daniel. Curso de direito constitucional. São Paulo: Editora Revista dos Tribunais, 2012.

; FENSTERSEIFER, Tiago. Direito Constitucional

Ambiental: estudos sobre a Constituição, os Direitos Fundamentais e a Proteção do Ambiente. São Paulo: Editora Revista dos Tribunais, 2011.

Dignidade da pessoa humana e direitos fundamentais na

Constituição Federal de 1988. 2. ed. Porto Alegre: Livraria do Advogado Editora, 2002.

SAVATIER, René. Les métamorphoses économiques et sociales du droit civil aujourd'hui. In: CARVAL, Suzanne. La Construction de la responsabilité civile: controverses doctrinales. Paris: PUF, 2001.

SAVIGNY, Friedrich Carl Von, De la vocación de nuestro siglo para la legislación y para la ciencia del derecho. Trad. Adolfo Posada. Granada: Editorial Comares, 2008. 
SCALISI, Vincenzo. Fonti-teoria-metodo: alla ricerca della regola giuridica nell'epoca della postmodernità. Milano: Giuffrè, 2012. e ammonirci che per ogni cosa non esiste una sola verità, ma esistono o possono esistere piú verità".

SCHREIBER, Anderson. Direitos da personalidade. São Paulo: Atlas, 2011.

Novos paradigmas da responsabilidade civil: da erosão dos filtros da reparação à diluição dos danos. São Paulo: Atlas, 2007.

SERRA, Sílvia Helena. Caso Soja Roundup Ready: a violação do princípio democrático e do princípio da publicidade pela CTNBio. In: Derani, Cristiane (Org.). Transgênicos no Brasil e Biossegurança. Porto Alegre: Sérgio Antônio Fabris Editora, 2005.

SILVA, Clóvis do Couto e. A obrigação como processo. Rio de Janeiro: Editora FGV, 2006.

. O conceito de dano no Direito brasileiro e comparado. In: FRADERA, Vera Maria Jacob de (Org.). O Direito Privado brasileiro na visão de Clóvis do Couto e Silva. Porto Alegre: Livraria do Advogado, 1997.

. O Direito Civil Brasileiro em perspectiva histórica e visão de futuro. In: FRADERA, Vera Maria Jacob de (Org.). O Direito Privado brasileiro na visão de Clóvis do Couto e Silva. Porto Alegre: Livraria do Advogado, 1997.

SILVA, João Calvão da. Compra e venda de coisas defeituosas: conformidade e segurança. Coimbra: Almedina, 2001.

1990.

. Responsabilidade civil do produtor. Almedina: Coimbra,

SILVA, José Afonso da. Curso de direito constitucional positivo. São Paulo: Malheiros, 2003.

SILVA, Virgílio Afonso da. Princípios e regras: mitos e equívocos acerca de uma distinção. Revista Latino-Americana de Estudos Constitucionais 1 (2003): 607-630.

SILVEIRA, Diana Montenegro da. Responsabilidade civil por danos causados por medicamentos defeituosos. Coimbra: Coimbra, 2010.

SINTEZ, Cyril. La sanction préventive em droit de la responsabilité civile: contribuition à la théorie de l'interprétation et de la mise en effet des normes. Paris: Dalloz, 2010 . 
SOARES, Guido Fernando Silva. Direito internacional do meio ambiente: emergência, obrigações e responsabilidades. São Paulo: Atlas, 2001.

SOUSA, Luís Filipe Pires de. Prova por presunção no direito civil. Coimbra: Almedina, 2012.

STANZIONE, Maria Gabriella. Principio di precauzione responsabilità civile e diritto alla salute nelle esperinze francese e italiana. Salermo: Brunolibri, 2010.

STARCK, Boris. Essai d'une théorie générale de la responsabilité civile considérée en sa double fonction de garantie et de peine privée. Paris: L. Rodstein, 1947.

STEIGLEDER, Annelise Monteiro. Responsabilidade civil ambiental: as dimensões do dano ambiental no direito brasileiro. $2^{\mathrm{a}}$ ed. Porto Alegre: Livraria do Advogado, 2011.

STIGLITZ, Gabriel A.; ECHEVESTI, Carlos A. Responsabilidad civil. In: ITURRASPE, Jorge Mosset. (Dir.); CARLUCCI, Aida Kemelmajer de. (Coord.). Buenos Aires: Hammurabi, 1997.

STOCO, Rui. Estudos em homenagem ao bicentenário do Código Civil francês. Disponível em <http://aplicaext.cjf.jus.br/phpdoc/pages/sen/.../textos.../rui_stoco.doc $>$. Acesso em: 20 jul. 2013.

STOFFEL-MUNCK, Philippe. Responsabilité civile. Chronique. JCP G nº38, 14 Septembre 2009.

SUSTEIN, Cass R. Para além do Princípio a Precaução. Tradução de Letícia Garcia Ribeiro. Revista de Direito Administrativo, Rio de Janeiro, v. 259, p.11-71, jan./abr. 2012.

Laws of fear: beyond the precautionary principle. Cambridge: Cambridge University Press, 2005.

SZANIAWSKI, Elimar. Direitos de personalidade e sua tutela. $2^{\text {a }}$ ed. São Paulo: Revista dos Tribunais, 2005.

TAPINOS, Daphné. Prévention, précaution et responsabilité civile : risque avéré, risque suspecté et transformation du paradigme de la responsabilité civile. Paris: L'Harmattan, 2008.

TEIXEIRA, Luciano Custódio. Alimentos transgênicos: questões controversas. Revista de Direito do Consumidor. Vol. 77. Jan.-Mar./2011.

TELLO, Antonio Eduardo Embid. Precaución y derecho: el caso de los campos 
electromagnéticos. Madrid: Iustel, 2010.

TEPEDINO, Gustavo, BARBOZA, Heloísa Helena; MORAES, Maria Celina Bodin de. Código Civil interpretado conforme a Constituição da República. $2^{\mathrm{a}}$ ed. Rio de Janeiro: Renovar, 2007.

TEPEDINO, Gustavo. A tutela da personalidade no ordenamento civil-constitucional brasileiro. Temas de direito civil. Rio de Janeiro: Renovar, 1999.

A responsabilidade civil por acidentes de consumo na ótica civilconstitucional. Temas de direito civil. Rio de Janeiro: Renovar, 1999.

TESAURO, Paolo; RECCIA, Giorgio. Origini ed evoluzione del modello dei "torts". In: MACIOCE, Francesco (a cura di). La responsabilità civile nei sistemi di common law. I - Profili generali. Padova: Cedam, 1989.

TESSLER, Luciane Gonçalves. Tutelas jurisdicionais ao meio ambiente: tutela inibitória, tutela de remoção, tutela do ressarcimento na forma específica. São Paulo: Editora Revista dos Tribunais, 2004.

TEUBNER, Gunther. Direito, sistema e policontexturalidade. São Paulo: Unimep, 2005.

THIBIERGE, Catherine. Avenir de la responsabilité, responsabilité de l'avenir. Recueil Dalloz. Paris. $n^{\circ}$ 9. p.577-582. mars/2004.

. Libres propôs sur l'évolution du droit de la responsabilité: vers um élargissement de la fonction de la responsabilité civile? Revue Trimestrielle de Droit Civil. Paris. n.3. p.561-84. juil./sept. 1999.

TOFFLER, Alvin. O choque do futuro. Trad. Marco Aurélio de Moura Matos. Rio de Janeiro: Artenova, 1973.

TOURNEAU, Philippe le. La responsabilité civile. Paris: PUF, 2003.

TRIMARCHI, Pietro. Causalità e danno. Milano: Giuffrè, .1967Rischio e responsabilità oggettiva. Milano: Dott. A. Giuffrè Editore, 1961.

VACCARO, Roberta. Nesso di causalità e prova statistica. Tesi di dottorato. Facoltà di Giurisprudenza. Università degli Studi "ROMA TRE”. 2010. 
VARELLA, Marcelo Dias (Org). Responsabilidade e socialização do risco - Estudos do Conselho de Estado Francês. Brasília: UNICEUB e UNITAR, 2006.

- Variações sobre um mesmo tema: o exemplo da implementação do Princípio da Precaução pela CIJ, OMC, CJCE e EUA. In: VARELLA, Marcelo Dias; PLATIAU, Ana Flávia Barros (Org.). Princípio da precaução. Belo Horizonte: Del Rey, 2004.

VASCONCELOS, Arnaldo. Teoria da norma jurídica. $6^{\text {a }}$ ed. São Paulo: Malheiros, 2006.

VAZ, Caroline. Funções da responsabilidade civil: da reparação à punição e dissuação. Porto Alegre: Livraria do Advogado, 2009.

VENOSA, Sílvio Sálvio. Direito civil: parte geral. 13a ed. São Paulo: Atlas, 2013.

VIGO, Rodolfo Luis. Interpretação jurídica: do modelo juspositivista-legalista do século XIX às novas perspectivas. 2. ed. rev. São Paulo: Editora Revista dos Tribunais, 2010 .

VINEY, Geneviève; JOURDAIN, Patrice. Traité de Droit Civil: Les effets de la responsabilité. $3^{\mathrm{e}}$ éd. Paris: LGDJ, 2010.

. As tendências atuais do Direito da Responsabilidade Civil. In:

TEPEDINO, Gustavo. Direito civil contemporâneo: novos problemas à luz da legalidade constitucional. São Paulo: Atlas, 2008.

Paris: LGDJ, 2008.

. Traité de Droit Civil: Introduction à la responsabilité. $3^{\mathrm{e}}$ éd.

; JOURDAIN, Patrice. Traité de droit civil: Les conditions de la responsabilité. 3e éd. Paris: L.G.D.J., 2006.

; KOURILSKY, Philippe. Le principe de précaution. Paris: Odile

Jacob, 2000.

Le déclin de la responsabilité individuelle. Paris: Librairie Générale de Droit et de Jurisprudence, 1965.

VISINTINI, Giovanna. Principi generali nella disciplina dei fatti illeciti e nuove aree di applicazione della responsabilità civile. In: VISINTINI, Giovanna (coord.). Dieci lezioni di diritto civile. Milano: Giuffrè, 2001. 
VOIDEY, Nadège. Le risque en droit civil. Paris: Presses Universitaires d'Aix-Marseille, 2005.

WARAT, Luís Alberto. O sentido comum teórico dos juristas. In: FARIA, José Eduardo (Org.). A crise do Direito numa sociedade em mudança. Brasília: Ed. Universidade de Brasília, 1988.

WARREN, Samuel D.; BRANDEIS, Louis. The right to privacy. Harvard Law Review. Disponível em: $<$ http://groups.csail.mit.edu/mac/classes/6.805/articles/privacy/Privacy_brand_warr2.html $>$ . Acesso em: 20 jul. 2013. Acesso em: 20 jul. 2013.

WEISS, Edith Brown. In Fairness To Future Generations and Sustainable Development. American University International Law Review. Vol. 8, n. 1, p.19-26, 1992.

WIEACKER, Franz. Diritto Privato e società industriale. Trad. Gianfranco Liberati. Napoli: Edizione Scientifiche Italiane, 1983.

WOLF, Erik. El problema del derecho natural. Trad. Manuel Entenza. Barcelona: Ariel, 1961.

WOLFRUM, Rüdiger. O princípio da precaução. In: VARELLA, Marcelo Dias; PLATIAU, Ana Flávia Barros (Org.). Princípio da precaução. Belo Horizonte: Del Rey, 2004.

WOLKMER, Antonio Carlos. Introdução ao pensamento jurídico crítico. 5. ed. rev. São Paulo: Saraiva, 2006.

World Commission on the Ethics of Scientific Knowledge and Technology (COMEST). The Precautionary Principle. France: UNESCO, 2005.

ZANDER, Joakim. The application of the Precautionary Principle in Practice: comparative dimensions. Cambridge: Cambridge University Press, 2010.

ZANNONI, Eduardo A. El daño en la responsabilidad civil. $2^{a}$ ed. Buenos Aires, 1993. 